Prepared in cooperation with the U.S. Environmental Protection Agency

\title{
Investigations of the Groundwater System and Simulation of Regional Groundwater Flow for North Penn Area 7 Superfund Site, Montgomery County, Pennsylvania
}

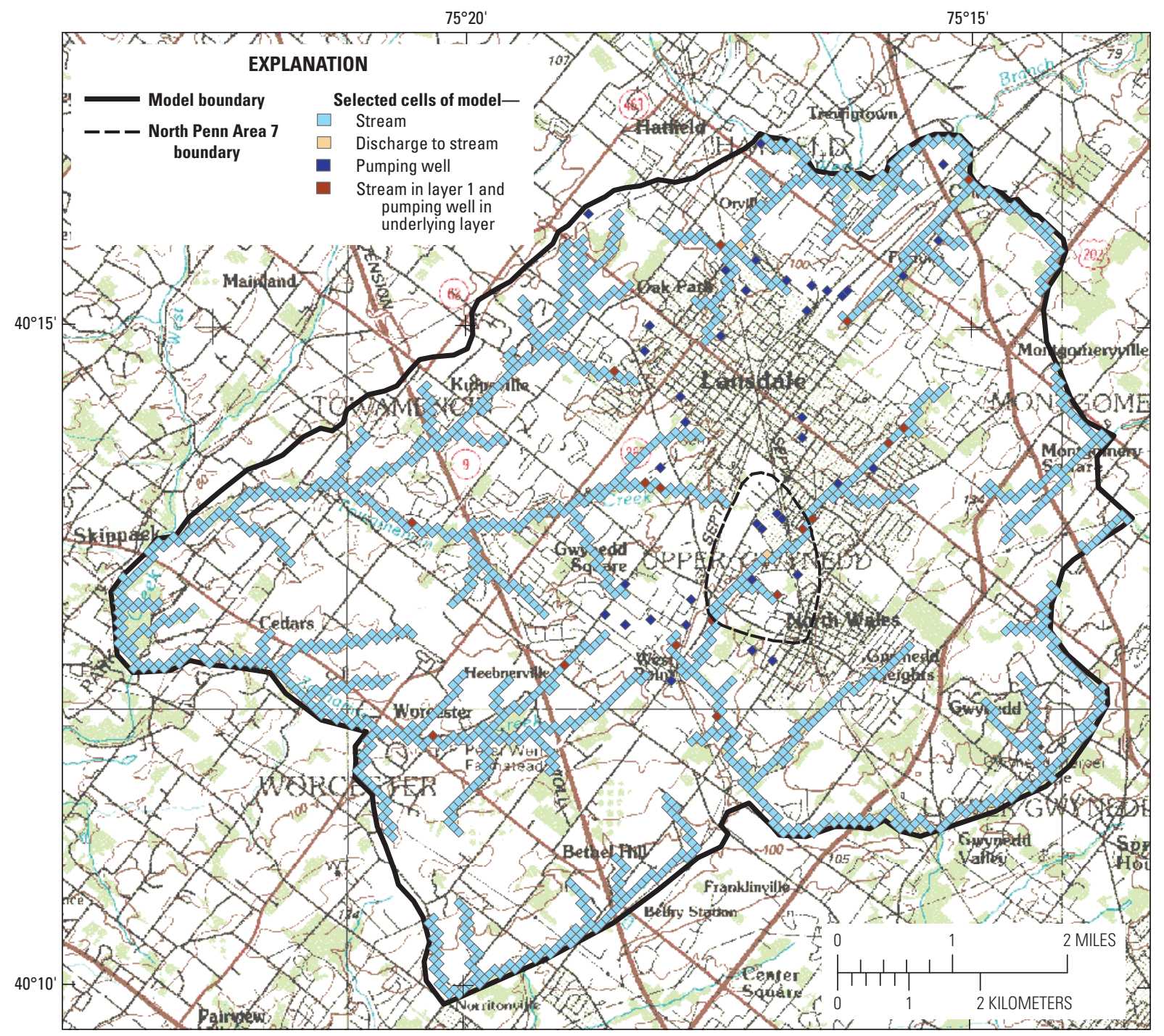

Scientific Investigations Report 2013-5045

Version 1.1, April 2015 
Front cover. Model boundary, streams cells, and pumped well cells for model of North Penn Area 7 Superfund site, Upper Gwynedd Township and vicinity, Montgomery County, Pennsylvania.

Back cover. Cross section in the dip direction of model grid for North Penn Area 7 Superfund site, Upper Gwynedd Township and vicinity, Montgomery County, Pennsylvania. (See figure 33 for location of line of section.) 


\section{Investigations of the Groundwater System and Simulation of Regional Groundwater Flow for North Penn Area 7 Superfund Site, Montgomery County, Pennsylvania}

By Lisa A. Senior and Daniel J. Goode

Prepared in cooperation with the U.S. Environmental Protection Agency

Scientific Investigations Report 2013-5045

Version 1.1, April 2015 


\title{
U.S. Department of the Interior \\ KEN SALAZAR, Secretary
}

\section{U.S. Geological Survey \\ Suzette M. Kimball, Acting Director}

\author{
U.S. Geological Survey, Reston, Virginia: 2013 \\ Revised: April 2015
}

\begin{abstract}
For more information on the USGS - the Federal source for science about the Earth, its natural and living resources, natural hazards, and the environment, visit http://www.usgs.gov or call 1-888-ASK-USGS.

For an overview of USGS information products, including maps, imagery, and publications, visit http://www.usgs.gov/pubprod

To order this and other USGS information products, visit http://store.usgs.gov
\end{abstract}

Any use of trade, firm, or product names is for descriptive purposes only and does not imply endorsement by the U.S. Government.

Although this information product, for the most part, is in the public domain, it also may contain copyrighted materials as noted in the text. Permission to reproduce copyrighted items must be secured from the copyright owner.

Suggested citation:

Senior, L.A., and Goode, D.J., 2013, Investigations of groundwater system and simulation of regional groundwater flow for North Penn Area 7 Superfund site, Montgomery County, Pennsylvania (ver. 1.1, April 2015:

U.S. Geological Survey Scientific Investigations Report 2013-5045, 95 p. 


\section{Acknowledgments}

The authors wish to thank the U.S. Geological Survey personnel who contributed substantially to this report. Philip H. Bird conducted borehole video logging, and Allan J. Ruddy and Leif E. Olson conducted water-level and streamflow measurements. Peter J. Cinotto, Leif E. Olson, and Robert Rosman conducted aquifer-interval isolation (packer) testing. Randall W. Conger conducted geophysical logging. J. Jeffrey Starn provided guidance on probabilistic modeling, and Richard B. Winston provided guidance on model preprocessing.

The authors gratefully acknowledge the assistance of U.S. Environmental Protection Agency (USEPA) project managers Deanna Moultrie-Jackson and David Turner, the guidance of USEPA hydrogeologist Kathy Davies, and the cooperation of CDM Federal Programs Corporation (USEPA contractor) consultants Andrew Hopton, Aaron Frantz, and Andrea Soo. Property and well owners in the study area are thanked for giving permission to access sampling locations. 


\section{Contents}

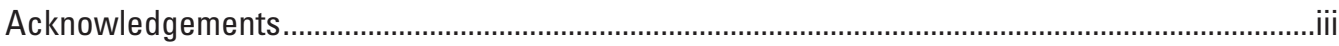

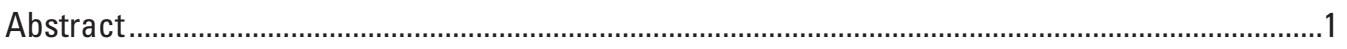

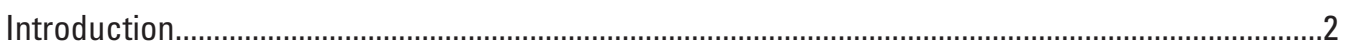

Purpose and scope

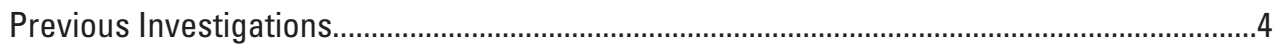

Well-Identification System ...............................................................................................

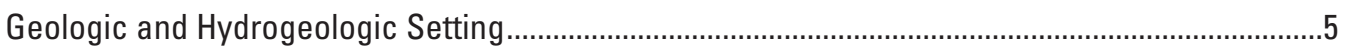

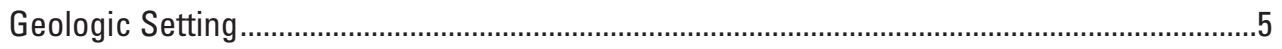

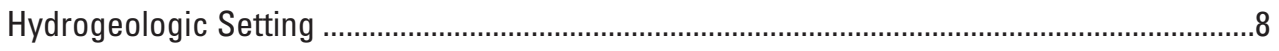

Summary of Field Investigations of Groundwater System at North Penn Area 7 ............................11

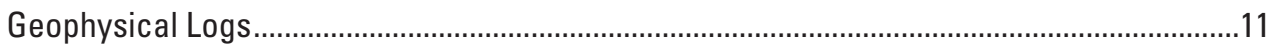

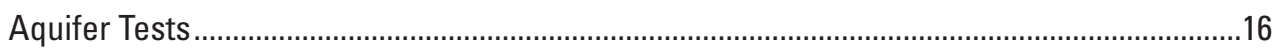

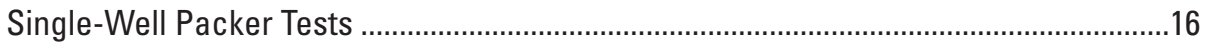

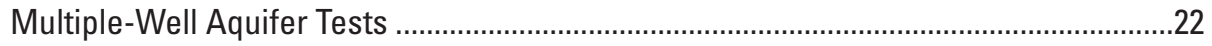

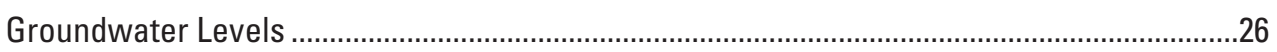

Streamflow Measurements and Groundwater/Surface-Water Relations .............................28

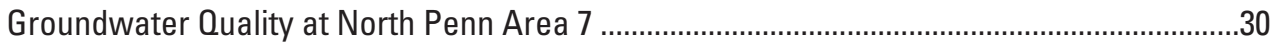

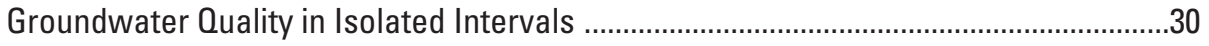

Groundwater Quality in Existing and New Monitor Wells .............................................31

Volatile Organic Compounds and Metals ................................................................33

Selected Inorganic Constituents .........................................................................

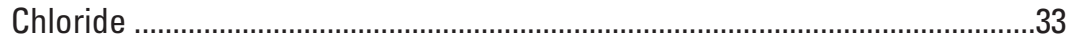

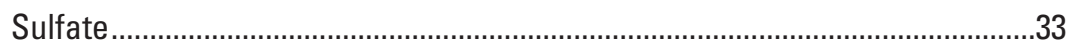

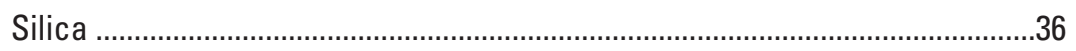

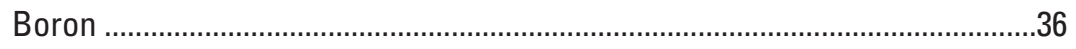

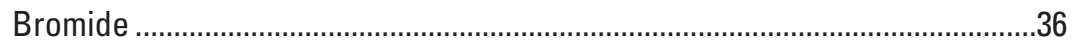

Inorganic Constituents as Tracers or Indicator of Lithology ...................................43

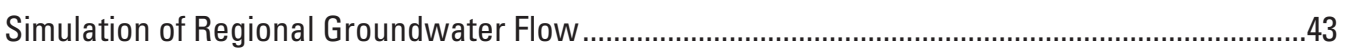

Estimation of Regional-Scale Aquifer Hydraulic Properties ..................................................4

Numerical Simulation of Regional Groundwater Flow .......................................................43

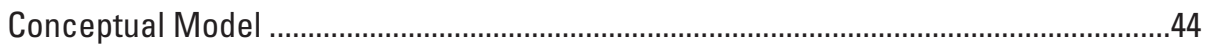

Model Structure and Boundary Conditions.................................................................4

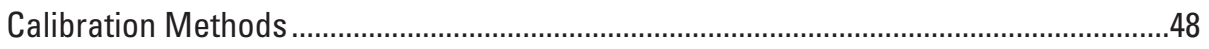

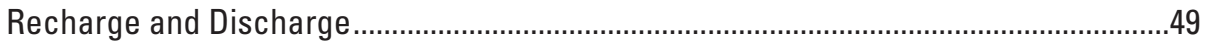

Measured and Simulated Water Levels in Wells ........................................................51

Estimated Aquifer Hydraulic Properties and Recharge Rates ........................................58

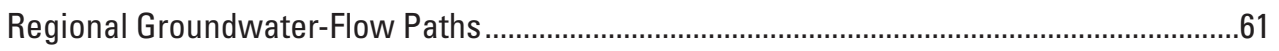

Simulated Flow Paths, Contributing Areas, and Uncertainty ...............................................61

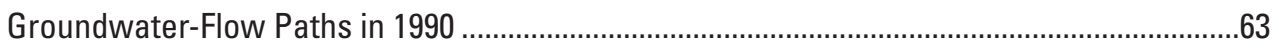

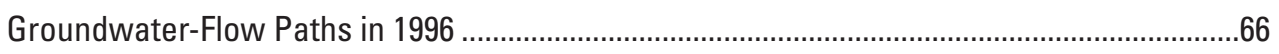

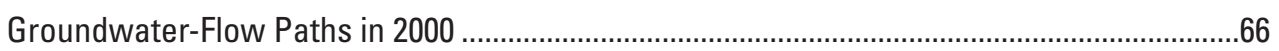


Groundwater-Flow Paths in 2005 .....................................................................................

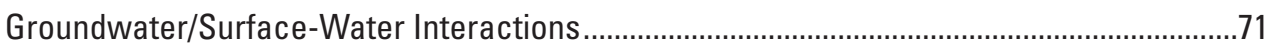

Simulated Shutdown of Well MG-202 .....................................................................................

Relation Between Water Quality and Groundwater Flow........................................................76

Inferred Flow Paths from Distribution of Measured Contaminants ................................76

Inferred Flow Paths from Observed Inorganic Constituent Distribution ..........................82

Limitations and Uncertainties in Predictive Simulations ........................................................85

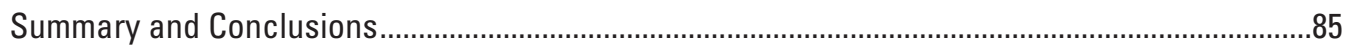

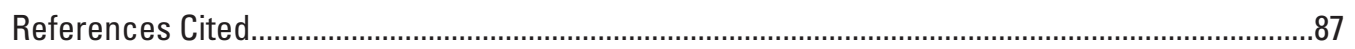

\section{Figures}

1. Map showing location of the North Penn Area 7 Superfund site and selected wells, Upper Gwynedd Township and vicinity, Montgomery County, Pennsylvania.....................3

2. Map showing physiographic provinces in southeastern Pennsylvania ...........................6

3. Map showing units of bedrock underlying North Penn Area 7 Superfund site and model boundary for North Penn Area 6 , Upper Gwynedd Township and vicinity, Montgomery County, Pennsylvania

4. Map showing preliminary revised lithologic mapping of bedrock geology at and near North Penn Area 7 Superfund site, Upper Gwynedd Township and vicinity, Montgomery County, Pennsylvania

5. A, cross section showing conceptual groundwater-flow system in dipping-bed fractured sedimentary rock aquifer and $B$, schematic cross section showing numerical simulation of groundwater flow in conceptual dipping-bed sedimentary rock aquifer with layered units of high and low permeability.

6. Map showing location of existing and new monitor wells with geophysical logs and packer tests conducted by U.S. Geological Survey at and near the North Penn Area 7 Superfund site, Upper Gwynedd Township and vicinity, Montgomery County, Pennsylvania, 2000-2005

7. Map showing direction of vertical gradients measured in boreholes and (or) determined from water levels in well clusters at and near North Penn Area 7 Superfund site, Upper Gwynedd Township and vicinity, Montgomery County, Pennsylvania, 2001-2005.

8. Natural gamma-ray logs indicating beds of elevated natural gamma-ray activity that can be correlated among boreholes/wells in the western part of North Penn Area 7 Superfund site, Upper Gwynedd Township and vicinity, Montgomery County, Pennsylvania ......

9. Interpreted correlation of natural gamma-ray activity and single-point resistance logs for monitor well clusters in the $A$, western (RI-15 cluster) and $B$, eastern (RI-8 cluster) parts of North Penn Area 7 Superfund site, Upper Gwynedd and vicinity, Montgomery County, Pennsylvania

10. Graph showing water levels in the isolated interval of $193 \mathrm{to} 215 \mathrm{ft}$ below land surface and adjacent intervals in well MG-2131 (RI-15DD) during the single-well packer tests, North Penn Area 7 Superfund site, Upper Gwynedd Township and vicinity, Montgomery County, Pennsylvania, June 10, 2005. 
11. Boxplots showing $A$, calculated transmissivities and $B$, hydraulic conductivities in relation to a range of depths for water-bearing intervals isolated by packers in 15 wells of similar depths, North Penn Area 7 Superfund site, Upper Gwynedd Township and vicinity, Montgomery County, Pennsylvania, March 2004 through August 2005.

12. Section $A-A^{\prime}$ with transmissivity of tested zones in selected wells that are projected onto a line approximately parallel to estimated dip of 10 degrees, North Penn Area 7 Superfund site, Upper Gwynedd Township and vicinity, Montgomery County, Pennsylvania

13. Boxplots showing $A$, calculated transmissivities and $B$, hydraulic conductivities, by mapped geologic unit, for water-bearing intervals isolated by packers in 15 wells of similar depths, North Penn Area 7 Superfund site, Upper Gwynedd Township and vicinity, Montgomery County, Pennsylvania, March 2004 through August 2005.

14. Map showing location of pumped production and observation wells used for multiple well aquifer tests, and lines of section $A-A^{\prime}$ and $B-B^{\prime}$, at North Penn Area 7 Superfund site, Upper Gwynedd Township and vicinity, Montgomery County, Pennsylvania, 2002-2005.

15. A, section $A-A^{\prime}$ with production well MG-202 (L-22) and 15 observation wells monitored during shutdown and after restart of pumping in well MG-202 in March 2002 and $B$, section $B-B^{\prime}$ with production well MG-202, 14 observation wells monitored during shutdown and restart of pumping in well MG-202 in December 2004, well MG-175 at the Spra-Fin property, and mapped geologic units at and near North Penn Area 7, Upper Gwynedd Township and vicinity, Montgomery County, Pennsylvania

16. Water-level responses to pumping of isolated intervals in well MG-2131 (RI-15DD) in June 2005, North Penn Area 7 Superfund site, Upper Gwynedd Township and vicinity, Montgomery County, Pennsylvania..

17. Graphs showing water levels measured in A, wells MG-2085 (RI-3I) and MG-2084 (RI-3D) and B, MG-2092 (RI-5S), MG-2091 (RI-5I), MG-2090 (RI-5D), and MG-2126 (RI-13D) during the packer test of well RI-15DD (MG-2131), June 9-13, 2005, North Penn Area 7 Superfund site, Upper Gwynedd Township and vicinity, Montgomery County, Pennsylvania

18. Graph showing water levels in long-term observation wells BK-929 and BK-1020 and in well MG-68, North Penn Area 7, Upper Gwynedd Township and vicinity, Montgomery County, Pennsylvania, 1996-2006.

19. Map showing location of pumped wells with pumping rates, observation wells, and streamflow-measurement sites for the June 2003 seepage investigation on Wissahickon Creek and lithology at and near North Penn Area 7, Upper Gwynedd Township and vicinity, Montgomery County, Pennsylvania.

20. Graph showing measured groundwater levels (shown as altitudes) in wells MG-72, MG-1145, and MG-1146 and estimated altitudes of the streambed of Wissahickon Creek near the wells, at and near North Penn Area 7 Superfund site, Upper Gwynedd Township and vicinity, Montgomery County, Pennsylvania, December 2000-November 2006.

21. Graphs showing specific conductance, acid neutralizing capacity as estimate of alkalinity, $\mathrm{pH}$, and concentrations of dissolved oxygen, nitrate, and sulfate measured in the field in water samples from isolated zones in 15 deep monitor wells, North Penn Area 7 Superfund site, Upper Gwynedd Township and vicinity, Montgomery County, Pennsylvania, March 2004 through August 2005. 
22. Map showing chloride concentrations in samples collected in spring 2006 from monitor well clusters and open-hole wells and line of section $A-A^{\prime}$, North Penn Area 7 Superfund site, Upper Gwynedd Township and vicinity, Montgomery County, Pennsylvania

23. Locations of monitor wells projected onto a line parallel to dip and chloride concentrations in samples collected from the monitor wells in spring 2006, North Penn Area 7 Superfund site, Upper Gwynedd Township and vicinity, Montgomery County, Pennsylvania.

24. Map showing silica concentrations in samples collected in fall 2005 from monitor well clusters and open-hole wells, and line of section $A-A^{\prime}$, North Penn Area 7 Superfund site, Upper Gwynedd Township and vicinity, Montgomery County, Pennsylvania .

25. Graph showing locations of monitor wells projected onto a line parallel to dip and silica concentrations in samples collected from the monitor wells in fall 2005, North Penn Area 7 Superfund site, Upper Gwynedd Township and vicinity, Montgomery County, Pennsylvania

26. Map showing boron concentrations in samples collected in spring 2006 from monitor well clusters and open-hole wells, and line of section $A-A^{\prime}$, North Penn Area 7 Superfund site, Upper Gwynedd Township and vicinity, Montgomery County, Pennsylvania

27. Graph showing locations of monitor wells projected onto a line parallel to dip and boron concentrations in samples collected from the monitor wells in spring 2006, North Penn Area 7 Superfund site, Upper Gwynedd Township and vicinity, Montgomery County, Pennsylvania.

28. Graph showing chloride/bromide mass ratio in relation to chloride concentration in water samples collected in March 2006 from monitor wells at and near North Penn Area 7 Superfund site, Upper Gwynedd Township and vicinity, Montgomery County, Pennsylvania .

29. Map showing spatial distribution of chloride/bromide mass ratios in water collected in March 2006 from monitor and existing open-hole wells, at and near North Penn Area 7 Superfund site, Upper Gwynedd Township and vicinity, Montgomery County, Pennsylvania

30. Map showing model boundary, streams cells, and pumped well cells for model of North Penn Area 7 Superfund site, Upper Gwynedd Township and vicinity, Montgomery County, Pennsylvania

31. Cross section in the dip direction of model grid for North Penn Area 7 Superfund site, Upper Gwynedd Township and vicinity, Montgomery County, Pennsylvania

32. Cross section in the strike direction of model grid for North Penn Area 7 Superfund site, Upper Gwynedd Township and vicinity, Montgomery County, Pennsylvania

33. Screen capture of model preprocessor showing structural contours for top of bed B4 (projected), layer 10 thickness for the model, and lines of section, North Penn Area 7 Superfund site, Upper Gwynedd Township and vicinity, Montgomery County, Pennsylvania .

34. Screen capture of model preprocessor showing locations of streamflow measurements, land-surface elevations at streams, and locations of pumped wells for the numerical model for North Penn Area 7 Superfund site, Upper Gwynedd Township and vicinity, Montgomery County, Pennsylvania...

35. Map showing simulated water-table altitudes and location of observation wells showing simulated water levels minus measured water levels in $A, 1996, B, 2000$, and $C, 2005$ for the model for North Penn Area 7 Superfund site, Upper Gwynedd Township and vicinity, Montgomery County, Pennsylvania.. 
36. Graph showing relation of measured groundwater-level altitudes to groundwaterlevel altitudes simulated by the numerical model for North Penn Area 7 Superfund site, Upper Gwynedd Township and vicinity, Montgomery County, Pennsylvania ..........58

37. Graph showing sensitivity of model calibration to model parameters for groundwater-flow simulation of North Penn Area 7 Superfund site and vicinity, Upper Gwynedd Township and vicinity, Montgomery County, Pennsylvania...

38. Map showing simulated groundwater-flow paths extending from contaminant source areas to pumped wells for pumping conditions in 1990 for North Penn Area 7 Superfund site, Upper Gwynedd Township and vicinity, Montgomery County, Pennsylvania

39. Map showing simulated area contributing recharge to well MG-202 (L-22) for pumping conditions in 1990 for North Penn Area 7 Superfund site, Upper Gwynedd Township and vicinity, Montgomery County, Pennsylvania

40. Map showing simulated groundwater-flow paths extending from contaminant source areas to pumped wells for pumping conditions in 1996 for North Penn Area 7 Superfund site, Upper Gwynedd Township and vicinity, Montgomery County, Pennsylvania

41. Map showing simulated area contributing recharge to well MG-202 (L-22) for pumping conditions in 1996 for North Penn Area 7 Superfund site, Upper Gwynedd Township and vicinity, Montgomery County, Pennsylvania

42. Map showing simulated groundwater-flow paths extending from contaminant source areas to pumped wells for pumping conditions in 2000 for North Penn Area 7 Superfund site, Upper Gwynedd Township and vicinity, Montgomery County, Pennsylvania

43. Map showing simulated area contributing recharge to well MG-202 (L-22) for pumping conditions in 2000 for North Penn Area 7 Superfund site, Upper Gwynedd Township and vicinity, Montgomery County, Pennsylvania

44. Map showing simulated groundwater-flow paths extending from contaminant source areas to pumped wells for pumping conditions in 2005 for North Penn Area 7 Superfund site, Upper Gwynedd Township and vicinity, Montgomery County, Pennsylvania

45. Map showing simulated area contributing recharge to well MG-202 (L-22) for pumping conditions in 2005 for North Penn Area 7 Superfund site, Upper Gwynedd Township and vicinity, Montgomery County, Pennsylvania

46. Map showing simulated stream loss and stream gain for the Upper Wissahickon Creek and other streams, and pumping rates for selected wells, in 2005, for the model for North Penn Area 7 Superfund site, Upper Gwynedd Township and vicinity, Montgomery County, Pennsylvania.

47. Map showing simulated area contributing recharge to well MG-76 (L-17) for pumping conditions in 2005 for North Penn Area 7 Superfund site, Upper Gwynedd Township and vicinity, Montgomery County, Pennsylvania 75

48. Maps showing measured water-level changes in observation wells at 1,000 minutes after shutdown of well MG-202 (L-22) in 2004 and simulated water-level recovery contours in the respective middle sub-layers of model layers after shutdown of well MG-202 (L-22): $A$, model layer 8 at at 1 day (1,440 minutes), $B$, model layer 8 at 7 days, and $C$, model layer 7 at 7 days, North Penn Area 7, Upper Gwynedd Township and vicinity, Montgomery County, Pennsylvania 
49. Maps showing simulated groundwater-flow paths for conditions in $A, 2005$ and $B, 1990$, and measured TCE concentrations in samples collected from observation wells in fall 2005, North Penn Area 7 Superfund site, Upper Gwynedd Township and vicinity, Montgomery County, Pennsylvania.

50. Maps showing simulated groundwater-flow paths for conditions in 2005 and measured concentrations of $A, C F C-11$ and $B, C F C-113$ in samples collected from observation wells in fall 2005, North Penn Area 7 Superfund site, Upper Gwynedd Township and vicinity, Montgomery County, Pennsylvania.

\section{Tables}

1. Characteristics of wells with geophysical logs collected and aquifer-intervalisolation (packer) tests conducted by the U.S. Geological Survey at and near North Penn Area 7 Superfund site, Upper Gwynedd Township and vicinity, Montgomery County, Pennsylvania, 2000-2005.

2. Summary statistics of physical and chemical characteristics measured in the field of unfiltered water samples collected from isolated zones in 15 deep monitor wells, North Penn Area 7 Superfund site, Upper Gwynedd Township and vicinity, Montgomery County, Pennsylvania, March 2004 through August 2005

3. Hydrostratigraphy used in the groundwater model for North Penn Area 7 Superfund site, Upper Gwynedd Township and vicinity, Montgomery County, Pennsylvania

4. Measured and simulated groundwater discharge to stream reaches for the calibrated numerical model of groundwater flow in the North Penn Area 7 Superfund site, Upper Gwynedd Township and vicinity, Montgomery County, Pennsylvania .

5. Pumping well identification, locations and pumping rates for North Penn Area 7 Superfund site, Upper Gwynedd Township and vicinity, Montgomery County, Pennsylvania ...

6. Water levels in wells used for calibration of the groundwater-flow model for North Penn Area 7 Superfund site, Upper Gwynedd Township and vicinity, Montgomery County, Pennsylvania...

7. Optimum and approximate, individual, 95-percent confidence-interval values for parameters estimated through calibration of the groundwater-flow model for North Penn Area 7 Superfund site, Upper Gwynedd Township and vicinity, Montgomery County, Pennsylvania

8. Simulated water budgets for calibration periods 1996, 2000, and 2005 for model area and North Penn Area 7 Superfund site, Upper Gwynedd Township and vicinity, Montgomery County, Pennsylvania

9. Correlation and variance/covariance matrices for generation of probabilistic parameters 


\section{Conversion Factors and Datums}

\begin{tabular}{|c|c|c|}
\hline Multiply & By & To obtain \\
\hline \multicolumn{3}{|c|}{ Length } \\
\hline inch (in) & 2.54 & centimeter $(\mathrm{cm})$ \\
\hline inch (in) & 25.4 & millimeter (mm) \\
\hline foot $(\mathrm{ft})$ & 0.3048 & meter $(\mathrm{m})$ \\
\hline mile (mi) & 1.609 & kilometer (km) \\
\hline \multicolumn{3}{|c|}{ Area } \\
\hline acre & 0.4047 & hectare (ha) \\
\hline acre & 0.004047 & square kilometer $\left(\mathrm{km}^{2}\right)$ \\
\hline square foot $\left(\mathrm{ft}^{2}\right)$ & 929.0 & square centimeter $\left(\mathrm{cm}^{2}\right)$ \\
\hline square foot $\left(\mathrm{ft}^{2}\right)$ & 0.09290 & square meter $\left(\mathrm{m}^{2}\right)$ \\
\hline square mile $\left(\mathrm{mi}^{2}\right)$ & 259.0 & hectare (ha) \\
\hline square mile $\left(\mathrm{mi}^{2}\right)$ & 2.590 & square kilometer $\left(\mathrm{km}^{2}\right)$ \\
\hline \multicolumn{3}{|c|}{ Volume } \\
\hline gallon (gal) & 3.785 & liter $(\mathrm{L})$ \\
\hline gallon (gal) & 0.003785 & cubic meter $\left(\mathrm{m}^{3}\right)$ \\
\hline gallon (gal) & 3.785 & cubic decimeter $\left(\mathrm{dm}^{3}\right)$ \\
\hline million gallons (Mgal) & 3,785 & cubic meter $\left(\mathrm{m}^{3}\right)$ \\
\hline cubic foot $\left(\mathrm{ft}^{3}\right)$ & 28.32 & cubic decimeter $\left(\mathrm{dm}^{3}\right)$ \\
\hline cubic foot $\left(\mathrm{ft}^{3}\right)$ & 0.02832 & cubic meter $\left(\mathrm{m}^{3}\right)$ \\
\hline \multicolumn{3}{|c|}{ Flow rate } \\
\hline foot per day $(\mathrm{ft} / \mathrm{d})$ & 0.3048 & meter per day $(\mathrm{m} / \mathrm{d})$ \\
\hline cubic foot per second $\left(\mathrm{ft}^{3} / \mathrm{s}\right)$ & 0.02832 & cubic meter per second $\left(\mathrm{m}^{3} / \mathrm{s}\right)$ \\
\hline $\begin{array}{l}\text { cubic foot per second per square } \\
\text { mile }\left[\left(\mathrm{ft}^{3} / \mathrm{s}\right) / \mathrm{mi}^{2}\right]\end{array}$ & 0.01093 & $\begin{array}{l}\text { cubic meter per second per square } \\
\text { kilometer }\left[\left(\mathrm{m}^{3} / \mathrm{s}\right) / \mathrm{km}^{2}\right]\end{array}$ \\
\hline cubic foot per day $\left(\mathrm{ft}^{3} / \mathrm{d}\right)$ & 0.02832 & cubic meter per day $\left(\mathrm{m}^{3} / \mathrm{d}\right)$ \\
\hline gallon per minute (gal/min) & 0.06309 & liter per second $(\mathrm{L} / \mathrm{s})$ \\
\hline gallon per day (gal/d) & 0.003785 & cubic meter per day $\left(\mathrm{m}^{3} / \mathrm{d}\right)$ \\
\hline $\begin{array}{l}\text { gallon per day per square mile } \\
\qquad\left[(\mathrm{gal} / \mathrm{d}) / \mathrm{mi}^{2}\right]\end{array}$ & 0.001461 & $\begin{array}{l}\text { cubic meter per day per square } \\
\text { kilometer }\left[\left(\mathrm{m}^{3} / \mathrm{d}\right) / \mathrm{km}^{2}\right]\end{array}$ \\
\hline million gallons per day (Mgal/d) & 0.04381 & cubic meter per second $\left(\mathrm{m}^{3} / \mathrm{s}\right)$ \\
\hline inch per year (in/yr) & 25.4 & millimeter per year (mm/yr) \\
\hline \multicolumn{3}{|c|}{ Specific capacity } \\
\hline $\begin{array}{l}\text { gallon per minute per foot } \\
[(\mathrm{gal} / \mathrm{min}) / \mathrm{ft})]\end{array}$ & 0.2070 & liter per second per meter $[(\mathrm{L} / \mathrm{s}) / \mathrm{m}]$ \\
\hline \multicolumn{3}{|c|}{ Hydraulic conductivity } \\
\hline foot per day $(\mathrm{ft} / \mathrm{d})$ & 0.3048 & meter per day $(\mathrm{m} / \mathrm{d})$ \\
\hline \multicolumn{3}{|c|}{ Hydraulic gradient } \\
\hline foot per mile (ft/mi) & 0.1894 & meter per kilometer $(\mathrm{m} / \mathrm{km})$ \\
\hline \multicolumn{3}{|c|}{ Transmissivity* } \\
\hline foot squared per day $\left(\mathrm{ft}^{2} / \mathrm{d}\right)$ & 0.09290 & meter squared per day $\left(\mathrm{m}^{2} / \mathrm{d}\right)$ \\
\hline \multicolumn{3}{|c|}{ Leakance } \\
\hline foot per day per foot $[(\mathrm{ft} / \mathrm{d}) / \mathrm{ft}]$ & 1 & meter per day per meter \\
\hline inch per year per foot [(in/yr)/ft] & 83.33 & $\begin{array}{l}\text { millimeter per year per meter } \\
\qquad[(\mathrm{mm} / \mathrm{yr}) / \mathrm{m}]\end{array}$ \\
\hline
\end{tabular}


Temperature in degrees Celsius $\left({ }^{\circ} \mathrm{C}\right)$ may be converted to degrees Fahrenheit $\left({ }^{\circ} \mathrm{F}\right)$ as follows:

${ }^{\circ} \mathrm{F}=\left(1.8 x^{\circ} \mathrm{C}\right)+32$

Temperature in degrees Fahrenheit $\left({ }^{\circ} \mathrm{F}\right)$ may be converted to degrees Celsius $\left({ }^{\circ} \mathrm{C}\right)$ as follows:

${ }^{\circ} \mathrm{C}=\left({ }^{\circ} \mathrm{F}-32\right) / 1.8$

Vertical coordinate information is referenced to the North American Vertical Datum of 1988

(NAVD 88) for data shown in feet, unless specified otherwise. Model input and output shown in meters are referenced to the National Geodetic Vertical Datum of 1929 (NGVD 29).

Horizontal coordinate information is referenced to the North American Datum on 1927 (NAD 27) for model input and output. Other data, unless otherwise specified, are referenced to the North American Datum of 1983 (NAD 83).

Altitude, as used in this report, refers to distance above the vertical datum.

*Transmissivity: The standard unit for transmissivity is cubic foot per day per square foot times foot of aquifer thickness [(ft $\left.3 / \mathrm{d}) / \mathrm{ft}^{2}\right] \mathrm{ft}$. In this report, the mathematically reduced form, foot squared per day $\left(\mathrm{ft}^{2} / \mathrm{d}\right)$, is used for convenience.

Specific conductance is given in microsiemens per centimeter at 25 degrees Celsius $(\mu \mathrm{S} / \mathrm{cm}$ at $\left.25^{\circ} \mathrm{C}\right)$.

Concentrations of chemical constituents in water are given either in milligrams per liter (mg/L) or micrograms per liter ( $\mu \mathrm{g} / \mathrm{L})$.

NOTE TO USGS USERS: Use of hectare (ha) as an alternative name for square hectometer $\left(\mathrm{hm}^{2}\right)$ is restricted to the measurement of small land or water areas. Use of liter (L) as a special name for cubic decimeter $\left(\mathrm{dm}^{3}\right)$ is restricted to the measurement of liquids and gases. No prefix other than milli should be used with liter. Metric ton (t) as a name for megagram (Mg) should be restricted to commercial usage, and no prefixes should be used with it. 


\title{
Investigations of the Groundwater System and Simulation of Regional Groundwater Flow for North Penn Area 7 Superfund Site, Montgomery County, Pennsylvania
}

\author{
By Lisa A. Senior and Daniel J. Goode
}

\section{Abstract}

Groundwater in the vicinity of several industrial facilities in Upper Gwynedd Township and vicinity, Montgomery County, in southeast Pennsylvania has been shown to be contaminated with volatile organic compounds (VOCs), the most common of which is the solvent trichloroethylene (TCE). The 2-square-mile area was placed on the National Priorities List as the North Penn Area 7 Superfund site by the U.S. Environmental Protection Agency (USEPA) in 1989. The U.S. Geological Survey (USGS) conducted geophysical logging, aquifer testing, and water-level monitoring, and measured streamflows in and near North Penn Area 7 from fall 2000 through fall 2006 in a technical assistance study for the USEPA to develop an understanding of the hydrogeologic framework in the area as part of the USEPA Remedial Investigation. In addition, the USGS developed a groundwater-flow computer model based on the hydrogeologic framework to simulate regional groundwater flow and to estimate directions of groundwater flow and pathways of groundwater contaminants.

The study area is underlain by Triassic- and Jurassic-age sandstones and shales of the Lockatong Formation and Brunswick Group in the Mesozoic Newark Basin. Regionally, these rocks strike northeast and dip to the northwest. The sequence of rocks form a fractured-sedimentary-rock aquifer that acts as a set of confined to partially confined layers of differing permeabilities. Depth to competent bedrock typically is less than $20 \mathrm{ft}$ below land surface. The aquifer layers are recharged locally by precipitation and discharge locally to streams. The general configuration of the potentiometric surface in the aquifer is similar to topography, except in areas affected by pumping. The headwaters of Wissahickon Creek are nearby, and the stream flows southwest, parallel to strike, to bisect North Penn Area 7. Groundwater is pumped in the vicinity of North Penn Area 7 for industrial use, public supply, and residential supply.

Results of field investigations by USGS at the site and results from other studies support, and are consistent with, a conceptual model of a layered leaky aquifer where the dip of the beds has a strong control on hydraulic connections in the groundwater system. Connections within and (or) parallel to bedding tend to be greater than across bedding.

Transmissivities of aquifer intervals isolated by packers ranged over three orders of magnitude [from about 2.8 to 2,290 square feet per day $\left(\mathrm{ft}^{2} / \mathrm{d}\right)$ or 0.26 to 213 square meters per day $\left.\left(\mathrm{m}^{2} / \mathrm{d}\right)\right]$, did not appear to differ much by mapped geologic unit, but showed some relation to depth being relatively smaller in the shallowest and deepest intervals ( 0 to $50 \mathrm{ft}$ and more than $250 \mathrm{ft}$ below land surface, respectively) compared to the intermediate depth intervals (50 to $250 \mathrm{ft}$ below land surface) tested. Transmissivities estimated from multiple-observation well aquifer tests ranged from about 700 to $2,300 \mathrm{ft}^{2} / \mathrm{d}\left(65\right.$ to $\left.214 \mathrm{~m}^{2} / \mathrm{d}\right)$. Results of chemical analyses of water from isolated intervals or monitoring wells open to short sections of the aquifer show vertical differences in concentrations; chloride and silica concentrations generally were greater in shallow intervals than in deeper intervals. Chloride concentrations greater than 100 milligrams per liter $(\mathrm{mg} / \mathrm{L})$, combined with distinctive chloride/bromide ratios, indicate a different source of chloride in the western part of North Penn Area 7 than elsewhere in the site.

Groundwater flow at a regional scale under steady-state conditions was simulated by use of a numerical model (MODFLOW-2000) for North Penn Area 7 with different layers representing saprolite/highly weathered rock near the surface and unweathered competent bedrock. The sedimentary formations that underlie the study area were modeled using dipping model layers for intermediate and deep zones of unweathered, fractured rock. Horizontal cell model size was 100 meters (m) by 100 meters ( $328 \mathrm{ft}$ by $328 \mathrm{ft}$ ), and model layer thickness ranged from $6 \mathrm{~m}(19.7 \mathrm{ft})$ representing shallow weathered rock and saprolite up to $200 \mathrm{~m}(656 \mathrm{ft})$ representing deeper dipping bedrock. The model did not include detailed structure to account for local-scale differences in hydraulic properties, with the result that local-scale groundwater flow may not be well simulated. Additional detailed multi-well aquifer tests would be needed to establish the extent of interconnection 
Groundwater System and Simulation of Flow for North Penn Area 7 Superfund Site, Montgomery County, Pennsylvania

between intervals at the local scale to address remediation of contamination at each source area.

This regional groundwater-flow model was calibrated against measured groundwater levels (1996, 2000, and 2005) and base flow estimated from selected streamflow measurements by use of nonlinear-regression parameter-estimation algorithms to determine hydraulic conductivity and anisotropy of hydraulic conductivity, streambed hydraulic conductivity, and recharge during calibration periods. Results of the simulation using the calibrated regional model indicate that the aquifer appears to be anisotropic where hydraulic conductivity is greatest parallel to the orientation of bedding of the formations underlying the area and least in the cross-bed direction. The maximum hydraulic conductivity is aligned with the average regional strike of the formations, which is "subhorizontal" in the model because the altitudes of the beds and model cells vary in the strike, as well as dip, direction. Estimated subhorizontal hydraulic conductivities (in strike direction parallel to dipping beds) range from 0.001 to 1.67 meters per day $(0.0032$ to 5.5 feet per day). The ratio of minimum (dip direction) to maximum (strike direction) subhorizontal hydraulic conductivity ranges from $1 / 3.1$ to $1 / 8.6$, and the ratio of vertical to horizontal hydraulic conductivity ranges from $1 / 1$ to $1 / 478$. However, limited available field data precluded rigorous calibration of vertical anisotropy in the model. Estimated recharge rates corresponding to calibration periods in 1996, 2000, and 2005 are 150,109 , and 124 millimeters per year $(5.9,4.3$, and 4.9 inches per year), respectively.

The calibrated groundwater-flow model was used to simulate groundwater flow under steady-state conditions during periods of relatively high withdrawals (pumpage) (1990) and relatively low withdrawals (2000 and 2005). Groundwater-flow paths originating from recharge areas near known areas of soil contamination (sources) were simulated. Pumped industrial and production wells captured more groundwater from several of these sources during 1990 than after 1990 when pumping declined or ceased and greater amounts of contaminated groundwater moved away from North Penn Area 7 Superfund site to surrounding areas. Uncertainty in simulated groundwater-flow paths from contaminant sources and contributing areas, resulting from uncertainty in estimated hydraulic properties of the model, was illustrated through Monte Carlo simulations. The effect of uncertainty in the vertical anisotropy was not included in the Monte Carlo simulations.

Contributing areas indicating the general configuration of groundwater flow towards production well MG-202 (L-22) in the study area also were simulated for the different time periods; as simulated, the flow paths do not pass through any identified contaminant source in North Penn Area 7. However, contributing areas to wells, such as MG-202, located near many pumped wells are particularly complex and, in some cases, include areas that contribute flow to streams that subsequently recharge the aquifer through stream loss. In these cases, water-quality constituents, including contaminants that are present in surface water may be drawn into the aquifer to nearby pumped wells. Results of a simulated shutdown of well MG-202 under steady-state 2005 conditions showed that the area contributing recharge for nearby production well MG-76 (L-17), when MG-202 is not pumping, shifts downstream and is similar to the area contributing recharge for MG-202 when both wells are pumping.

Concentrations of constituents in groundwater samples collected in fall 2005 or spring 2006 were compared to simulated groundwater-flow paths for the year 2005 to provide a qualitative assessment of model results. The observed spatial distribution of selected constituents, including TCE, CFC-11, and CFC-113 in groundwater in 2005 and the chloride/bromide mass ratios in 2006, generally were consistent with the model results of the simulated 2005 groundwater-flow paths at North Penn Area 7, indicating the presence of several separate sources of contaminants within North Penn Area 7.

\section{Introduction}

Groundwater in and around Lansdale Borough and Upper Gwynedd Township, Montgomery County, Pennsylvania, was found to be contaminated with organic chemicals, such as trichloroethylene (TCE) and tetrachloroethylene (PCE), in 1979. The contamination was discovered by the North Penn Water Authority (NPWA), which at that time relied entirely on groundwater to supply public drinking water. The U.S. Environmental Protection Agency (USEPA) investigated sources of soil and groundwater contamination in the vicinity of Lansdale and subdivided the areas of contamination into groups of properties. The group of contaminated properties in the vicinity of production well L-22 (MG-202) in Upper Gwynedd Township, southeast of Lansdale and northwest of North Wales, was designated North Penn Area 7 and covers about 2 square miles $\left(\mathrm{mi}^{2}\right)$ (fig. 1). Well L-22 (MG-202) is one of several production wells near the headwaters of Wissahickon Creek located in an area shown as the Wissahickon well field on figure 1. The USEPA began its investigation at North Penn Area 7 in June 1986, and the site was placed on the National Priorities List (NPL) on March 31, 1989 (CH2M Hill, 1992). North Penn Area 7 is southeast from and nearly adjacent to the NPL (also known as Superfund) site North Penn Area 6 centered in Lansdale (fig. 1).

The North Penn Area 7 Superfund site encompasses six industrial facilities (fig. 1) reported to have used volatile organic compounds (VOCs). The most commonly used VOCs were the solvents TCE, PCE, 1,1,1-trichloroethane $(1,1,1-$ TCA), methylene chloride (MC), trichloromonofluoromethane (Freon-11 or CFC-11), and dichlorofluoromethane (Freon-21) (CH2M-Hill, Inc., 1992, p. 2-1 to 2-6). Contaminants of concern detected in groundwater in the vicinity of the site include TCE, PCE, 1,1,1-TCA, 1,1-dichloroethylene (1,1-DCE), 1,2-dichloroethylene (1,2-DCE), cis-1,2,-DCE, trans-1,2-DCE, vinyl chloride (VC), and carbon tetrachloride. Similar contamination also was detected in soils on at least six properties (CH2M-Hill, 1992). 


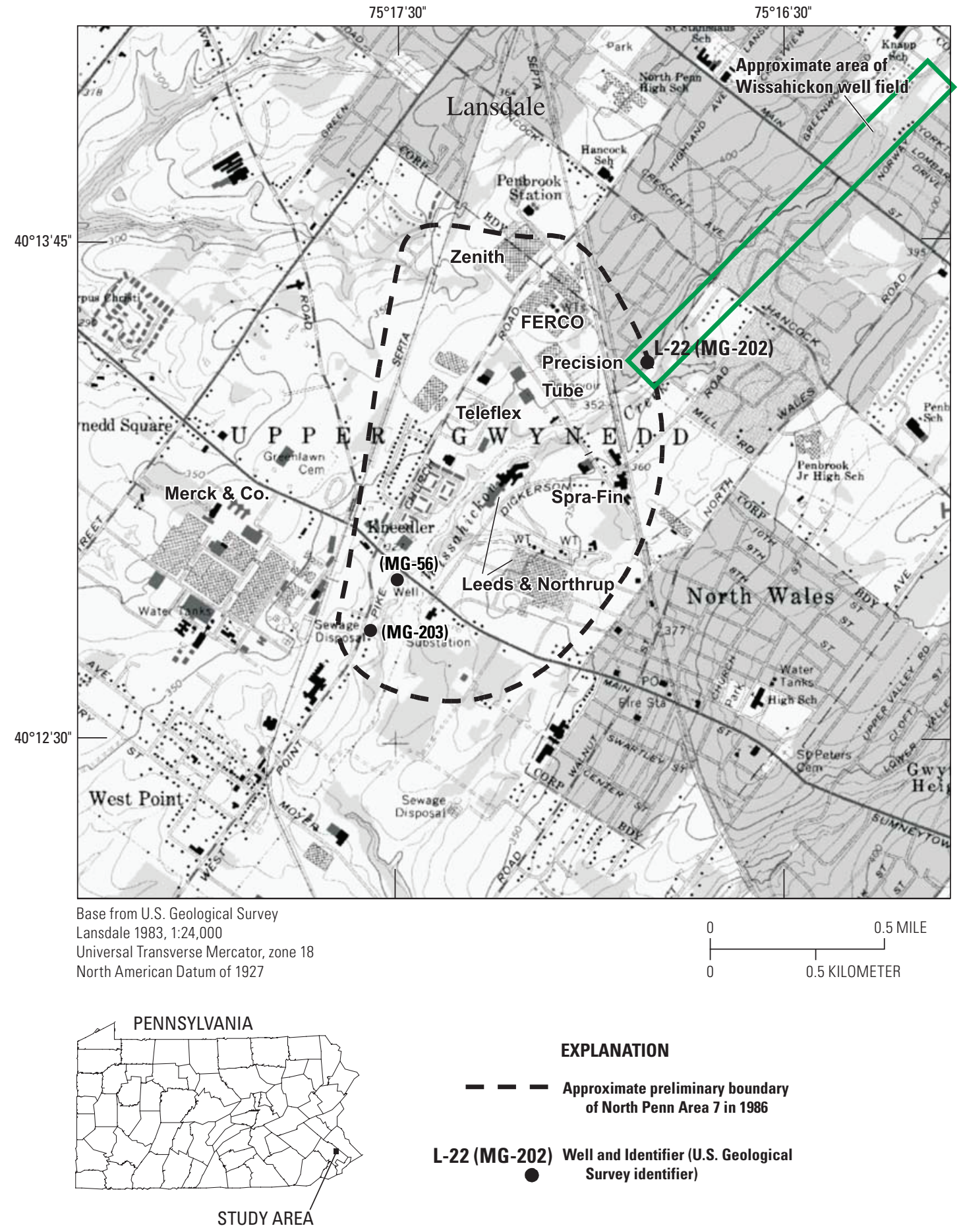

Figure 1. Location of the North Penn Area 7 Superfund site and selected wells, Upper Gwynedd Township and vicinity, Montgomery County, Pennsylvania. 
Groundwater in the vicinity of North Penn Area 7 has been used and continues to be used for industrial, public, and private supply. Although some wells were abandoned after contamination was discovered, other wells remain active, in some cases such as well L-22 (MG-202), equipped with air strippers to remove VOCs. Abandoned wells include two contaminated North Wales Water Authority (NWWA) production wells just south of North Penn Area 7 (MG-56, MG-203) and five industrial wells at the former FERCO property in the northern part of the site (fig. 1). As of fall 2006, groundwater pumping in the vicinity (within 0.5 miles) of North Penn Area 7 continued in NPWA wells along Wissahickon Creek near well L-22 (MG-202) to the northeast of the site, wells at Precision Tube near the center of the site, and wells at the West Point facility of Merck \& Co., Inc., southwest of the North Penn Area 7 (fig. 1).

The USEPA requested technical assistance from the U.S. Geological Survey (USGS) to provide hydrogeologic data and interpretation of the data to be used in the Remedial Investigation (RI) for the North Penn Area 7 Superfund site. In fall 2000, the USGS, in cooperation with USEPA and in coordination with USEPA's contractor CDM Federal Programs Corporation (CDM in this report; renamed CDMSmith in late 2011), began to collect data as part of the technical assistance. The data were used to describe the groundwater system and to provide a basis for the simulation of groundwater flow. The first phase of work, completed in September 2002, included geophysical logging of existing wells, aquifer tests of isolated intervals in existing wells, streamflow measurements, and groundwater-level mapping and monitoring (Senior and others, 2005; Senior and Ruddy, 2004). The second phase of work from October 2002 through December 2006 included geophysical logging of existing production and monitor wells and new monitor wells drilled for the RI, aquifer tests of isolated intervals in previously constructed and new monitor wells, streamflow measurements, and groundwater-level monitoring (Senior and others, 2008). In addition to collection and interpretation of data, the USGS also developed a computer model, described in this report, to simulate groundwater flow at and near North Penn Area 7. The groundwater-flow simulation is used to evaluate the effect of pumping on the directions of groundwater flow and transport of contaminants in groundwater.

\section{Purpose and scope}

This report describes the hydrogeologic setting and groundwater system on the basis of previous studies and findings from two phases of data collection and investigations by the USGS at the North Penn Area 7 Superfund site and vicinity. In addition, a computer-based numerical model that was constructed to simulate regional-scale groundwater flow is described. This model was used to estimate values for aquifer properties and simulate groundwater-flow directions under different conditions.
Data collected by USGS during the two phases-December 2000 through September 2002 and October 2002 through September 2006 - to help describe the hydrogeologic system at and near the site are summarized. These data include results of geophysical logs of existing production wells and existing and new monitor wells, aquifer characteristics determined from pumping tests of aquifer intervals isolated by packers (packer tests) in selected existing and new wells, results of water-quality analyses of groundwater samples from the packer tests, results of aquifer tests involving multiple observation wells, streamflow measurements, continuous groundwater levels in selected observation wells, and sets of synoptic measurements of groundwater levels in wells at and near the site. In addition, inorganic water-quality constituents in groundwater samples collected by CDM during October 2005 and March 2006 are discussed in relation to the hydrogeologic system.

Aquifer properties of transmissivity, hydraulic conductivity, and (or) storage were estimated when possible from the field data at the local scale (aquifer tests) and from a computer-based numerical simulation of groundwater flow at the regional scale. The basis of the numerical simulation of regional groundwater flow is described, including the conceptual model, model structure and boundaries, and calibration using regression-based parameter estimation (optimization) techniques. Data used for calibration include sets of synoptic groundwater levels and streamflow measurements from 1996 to 2005 .

The calibrated model is used to simulate groundwaterflow paths from known and suspected sources of contamination for selected periods from 1990 to 2005 that correspond to various industrial and water-supply pumping rates and locations (scenarios). The uncertainty associated with model simulation of flow paths determined using a Monte Carlo approach is shown with the flow paths simulated using optimized parameters. Similarly, the area contributing recharge to a contaminated production well and associated uncertainty of that area are simulated for the same periods. Simulated groundwater-flow paths from contaminant sources are compared to measured concentrations of selected VOCs in well-water samples collected in 2005 for qualitative assessment of model results. In addition, the distribution of selected inorganic constituents (boron, bromide, chloride, sulfate, and silica) analyzed in samples collected in fall 2005 and spring 2006 are discussed in relation to the hydrogeologic framework and groundwater-flow paths.

\section{Previous Investigations}

Groundwater studies in and near Lansdale Borough and Upper Gwynedd Township have been prompted by concern about limited groundwater availability during periods of drought, by discovery of contaminated drinking water from production wells, and by interest in commercial and industrial uses of the groundwater. Rima (1955), Longwill and Wood 
(1965), and Newport (1971) provide well-characteristic and groundwater-quality data and describe groundwater resources in Montgomery County, Pa., including the Lansdale and Upper Gwynedd Township area. Longwill and Wood (1965) compiled a geologic map, which in the Lansdale area was based almost entirely on unpublished manuscripts by Dean B. McLaughlin of the Pennsylvania Geological Survey. Lyttle and Epstein (1987) compiled a geologic map of the Newark $1^{\circ} \times 2^{\circ}$ Quadrangle that updates and revises the geologic nomenclature for the area. Biesecker and others (1968) describe the water resources of the Schuylkill River Basin, which drains part of the study area. Barton and others (2003) describe a case study to determine contributing area for a production well in Lansdale that is near North Penn Area 7.

Investigations of groundwater contamination after 1979 by the USEPA and others are summarized in a report to the USEPA by CH2MHill (1992). An evaluation of groundwater withdrawals at the Merck \& Co., Inc., (hereinafter "Merck") West Point plant was done by Geraghty \& Miller, Inc. (1993). Investigations of groundwater quality at the Ford Electronics and Refrigeration Corporation (FERCO) facility in North Penn Area 7 are described by Converse Consultants East (1994). Sources of groundwater contamination in the nearby North Penn Area 6 site also are identified in other reports to the USEPA by Black \& Veatch Waste Science, Inc. (1994; 1999).

Investigations since 2000 further delineated soils contaminated with TCE and other VOCs at Spra-Fin (CDM Federal Programs Corporation, 2003), former FERCO (Golder Associates, Inc. 2003), and Teleflex (Turner, 2006) properties.

A map of groundwater levels in 1996 in the vicinity of Lansdale that includes groundwater levels within North Penn Area 7 was done by Senior and others (1998) to support groundwater investigations at the nearby North Penn Area 6 site (fig. 1). Goode and Senior (1998) present a review of aquifer tests done in the Lansdale area from 1980 through 1995, including tests done in industrial supply wells at manufacturing facilities in and near North Penn Area 7. Senior and Goode (1999) describe the groundwater system and simulation of groundwater flow for the North Penn Area 6 site and vicinity. The model domain for previous North Penn Area 6 (shown later in report on fig. 3) groundwater-flow simulations (Senior and Goode, 1999; Goode and Senior, 2000) extended into North Penn Area 7 and was bounded by Wissahickon Creek. Studies (Senior and Goode,1999; Goode and Senior, 2000) that investigated the control on groundwater flow by the hydrogeologic structure of dipping sedimentary beds through field studies and flow modeling for North Penn Area 6 provide a basic framework for subsequent USGS work in the Lansdale area, including North Penn Area 7.

The study discussed in this report included two phases of data collection. Data collected during phase 1 (December 2000-September 2002) were published by Senior and others (2005), including a map showing groundwater levels in and near North Penn Area 7 in December 2000 (Senior and Ruddy, 2004). Data collected during phase 2 (October 2002-September 2006) were published by Senior and others (2008).

\section{Well-Identification System}

This report uses the USGS local well number as the primary well identification and the owner-assigned well number as the secondary well identification. The USGS local well number consists of a two-letter county-abbreviation prefix followed by a sequentially assigned number. The prefix MG denotes a well in Montgomery County. The USGS also assigns each well a unique 15-digit site number based on latitude and longitude in degrees, minutes, and seconds and a 2-digit sequence number. The 15-digit site number is the primary identifier in the USGS databases. Some wells have other names or numbers assigned by owners or used in the CH2M-Hill report (1992). The owner assigned well number commonly has a prefix consisting of a letter or letters followed by a sequentially assigned number; the new monitor wells drilled by USEPA in clusters for the remedial investigation (RI) use the prefix RI and a number for the cluster and are further identified as shallow (S), intermediate (I), deep (D), or extra-deep (DD). Listings of USGS local well and site numbers and owner-assigned well numbers for most wells cited in this report are given in tables 67,79, and 22, at the end of the two previous data reports for North Penn Area 7 (Senior and others, 2005; 2008) and a report for North Penn Area 6 (Senior and Goode, 1999).

\section{Geologic and Hydrogeologic Setting}

The composition and structure of bedrock underlying North Penn Area 7 and surrounding areas is a controlling factor that affects topography, character of the groundwater system, and stream network. The general geologic and hydrogeologic setting of the study area described below is based mostly on previous work by others and on work done by USGS at North Penn Area 7 and nearby North Penn Area 6 Superfund sites. Nomenclature (code) assigned to geologic units used in the simulation of regional groundwater flow presented in this report is described. Detailed investigations of the groundwater system at the local or borehole-scale that were done at and near North Penn Area 7 from December 2000 through September 2006 are summarized in a separate section of this report and presented completely in two previous reports (Senior and others, 2005; 2008).

\section{Geologic Setting}

The study area in and near Lansdale and Upper Gwynedd Township is in the Gettysburg-Newark Lowlands section of the Piedmont Physiographic Province (Berg and others, 1989; fig. 2). The area is underlain by sedimentary rocks of the Lockatong Formation and lower beds of the Brunswick Group of the Newark Supergroup (Lyttle and Epstein, 1987; fig. 3). Sediments of the Newark Supergroup were deposited in a rift basin during the Triassic and Jurassic ages (about 260 million 


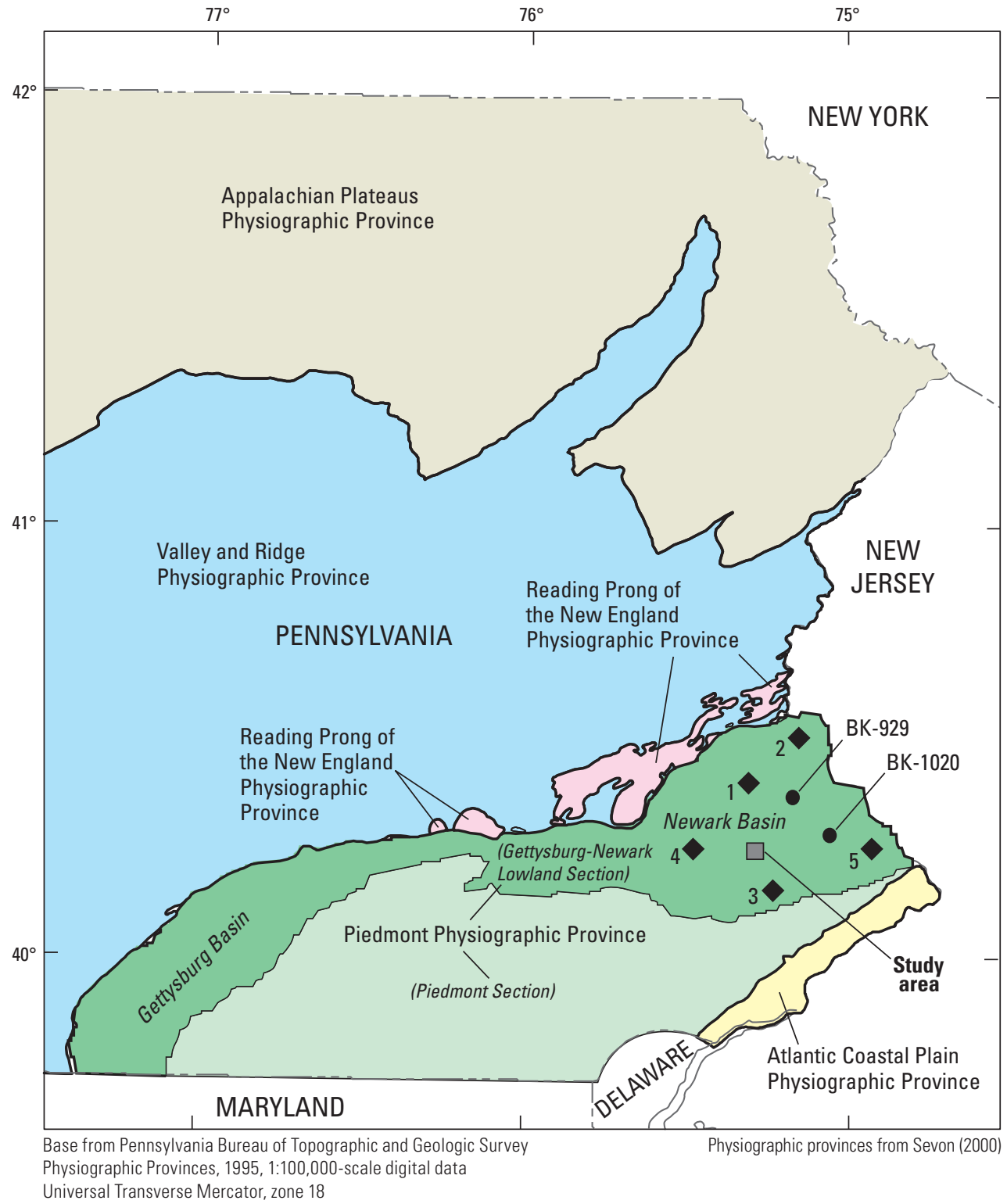

EXPLANATION

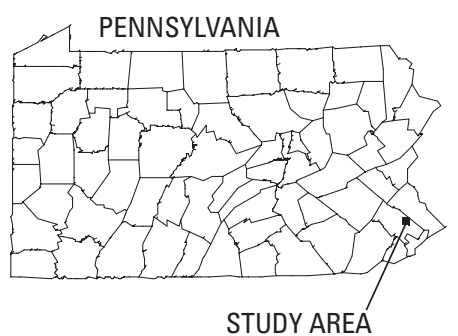

BK-929 Observation well and U.S. Geological Survey

identifier

National Oceanic and Atmospheric Administration precipitation station and identifier

1 - Sellersville

2 - Bucksville

3 - Conshohocken

4 - Graterford

5 - Neshaminy Falls

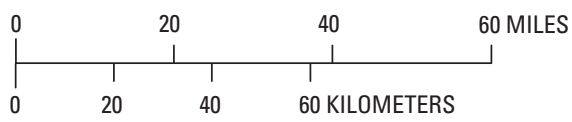

Figure 2. Physiographic Provinces in southeastern Pennsylvania. 


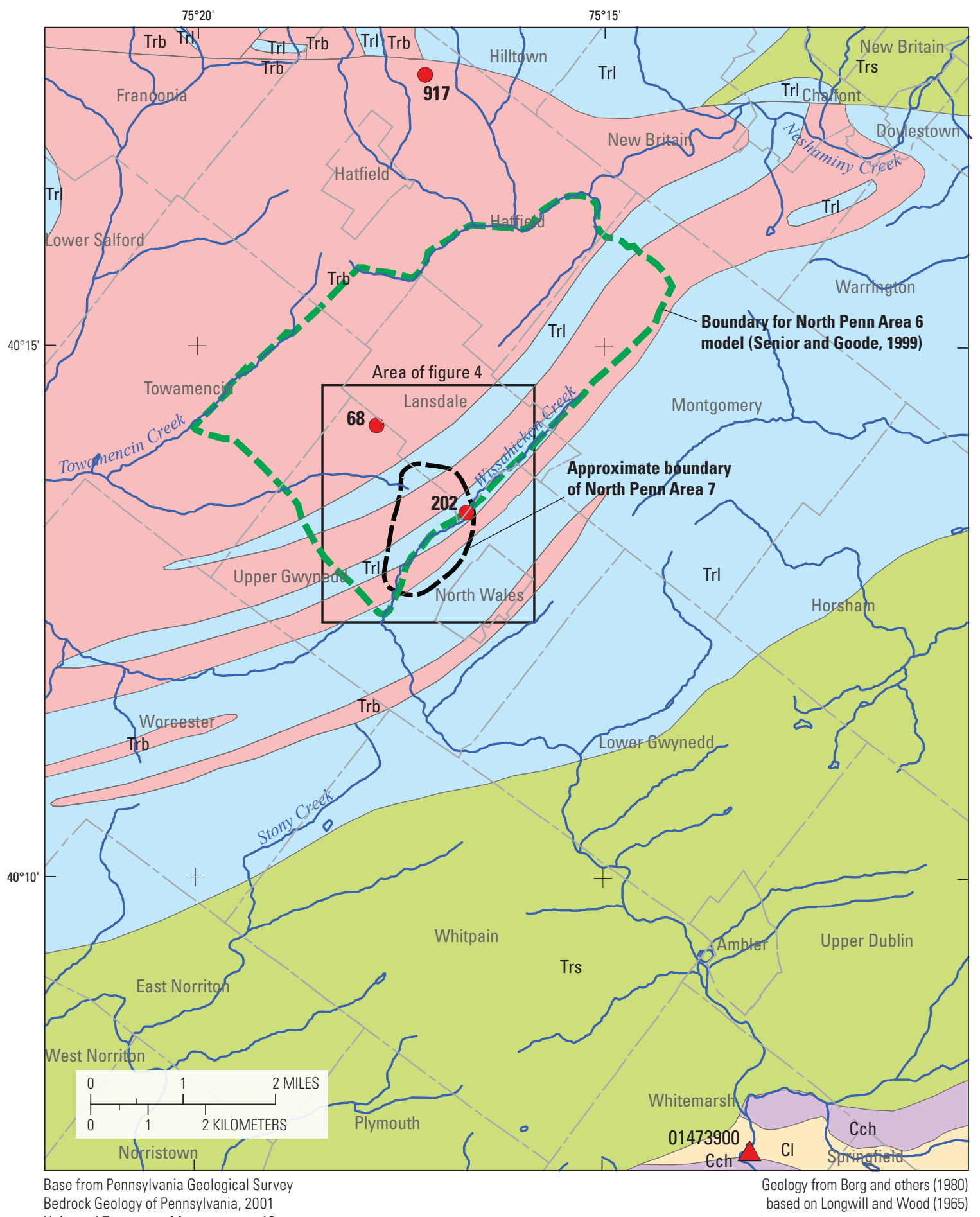

Bedrock Geology of Pennsylvania, 2001

Universal Transverse Mercator, zone 18

North American Datum of 1927

\begin{tabular}{|c|c|}
\hline & Geologic unit \\
\hline Trb & Brunswick Group \\
\hline Trl & Lockatong Formation \\
\hline Trs & Stockton Formation \\
\hline $\mathrm{Cl}$ & Ledger Formation \\
\hline Cch & Chickies Formation \\
\hline
\end{tabular}

EXPLANATION

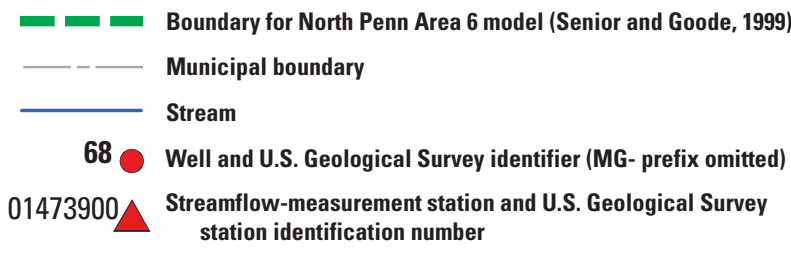

Figure 3. Units of bedrock underlying North Penn Area 7 Superfund site and model boundary for North Penn Area 6 , Upper Gwynedd Township and vicinity, Montgomery County, Pennsylvania. 
years ago). Following deposition, sediments in the Newark Basin were buried, lithified, tilted, and faulted. The oldest sediments in the Newark Basin compose the Stockton Formation, mainly sandstones with some shale deposited along the southern margin on Paleozoic and older rocks. Overlying the Stockton Formation are the generally finer-grained Lockatong Formation and Brunswick Group rocks, which underlie the study area. The Lockatong Formation typically is relatively resistant to erosion and tends to form ridges that rise above flat or rolling topography. This flat or rolling topography is underlain by sedimentary rocks of the Brunswick Group that are younger than and may be interfingered with the Lockatong Formation.

The Lockatong Formation consists of detrital sequences (cycles) of gray to black calcareous shale and siltstone, with some pyrite, and chemical sequences (cycles) of gray to black dolomitic siltstone and marlstone with lenses of pyritic limestone, overlain by massive gray to red siltstone with anacline (Van Houten, 1962; Lyttle and Epstein, 1987). Interbeds of reddish-brown, sandy siltstone have been mapped in the Lockatong Formation south of Lansdale (Lyttle and Epstein, 1987). Contacts between the Lockatong Formation and the overlying Brunswick Group are conformable and gradational, and the two formations may interfinger (Lyttle and Epstein, 1987). The lower beds of the Brunswick Group consist predominantly of homogeneous, soft, red to reddish-brown and gray to greenish-gray mudstones and clay- and mud-shales, with some fine-grained sandstones and siltstones. Bedding is irregular and wavy. Some beds are micaceous. Interbedded silt-shales and siltstones are moderately well sorted. Mud cracks, ripple marks, crossbeds, and worm burrows are common in all the beds. The Brunswick Group rocks contain detrital cycles of medium- to dark-gray and olive- to greenish-gray, thin-bedded and evenly bedded shale and siltstone, similar to those of the underlying Lockatong Formation.

Unpublished lithologic maps (Joseph Smoot, U.S. Geological Survey, written commun., 2005) indicate that deltaic and fluvial sequences are present in the geologic units mapped in the study area (fig. 4). This preliminary lithologic mapping retains geologic contacts presented in earlier mapping (Longwill and Wood, 1965) (fig. 3) but adds a new contact delimiting the extent of deltaic sequences in the lower part of the Brunswick Group rocks. The lithologic mapping identified interbedded fluvial to deltaic sandstone and conglomerate and lacustrine cyclic siltstone and shale that are predominantly red $\left(\mathrm{TrS} / \mathrm{Si}_{\mathrm{c}}\right.$ ) or predominantly gray $(\mathrm{TrS} / \mathrm{Si} \mathrm{g}$ ) (fig. 4). For the purposes of this report, these bedding units are assigned codes: $\mathrm{B} 4, \mathrm{~B} 6, \mathrm{~B} 8$, and B10 refer to units with the predominantly red lithology labeled $\mathrm{TrS} / \mathrm{Si}_{c} ; \mathrm{L} 5, \mathrm{~L} 7$, and L9 refer to units with the predominantly gray lithology labeled $\mathrm{TrS} / \mathrm{Si} \mathrm{c}_{\mathrm{c}} \mathrm{g}$; B refers to the predominantly red non-deltaic lower Brunswick Group rocks labeled $\mathrm{TrSi}_{\mathrm{c}}$ [equivalent to $\mathrm{Trb}$ of Longwill and Wood (1965)]; and L refers to the predominantly gray non-deltaic Lockatong Formation rocks labeled $\mathrm{TrSi}_{\mathrm{c}} \mathrm{g}$ [equivalent to the Trl of Longwill and Wood (1965)]. Prior to the unpublished mapping by Smoot, Lyttle and Epstein (1987) had reclassified the predominantly gray beds mapped by Longwill and Wood (1965) as interfingered Lockatong Formation within the Brunswick Group (fig. 3) as part of the lower Brunwick Group (see units labeled Trblg in fig. 4) and the predominantly red beds mapped as interfingered Brunswick Group with the Lockatong Formation (fig. 3) as part of the Lockatong Formation (see unit labeled Trlr in fig. 4).

Bedding in the Newark Basin regionally strikes northeast and dips to the northwest. The regional homoclinal dip has been cut by normal and strike-slip faults and warped by transverse folds (Schlische, 1992). Many faults with small displacements have not been mapped. Locally, the beds of the Brunswick Group and Lockatong Formation generally strike northeast and dip shallowly to the northwest in the vicinity of the North Penn Area 7 site with a gradual shift in strike from northeast in central Lansdale to east-northeast in the area south of Lansdale near North Wales (fig. 3) (Longwill and Wood, 1965). Thin shale marker beds in the Brunswick Group identified by elevated natural gamma-ray activity on geophysical logs can be correlated in wells and boreholes over distances of $1,000 \mathrm{ft}$ or more. High natural gamma-ray activity typically is associated with thin dark gray or black shale beds. Correlation of natural gamma-ray activity in well and borehole logs collected by USGS in and near Lansdale shows that these shale beds strike N. $48^{\circ}$ to $60^{\circ} \mathrm{E}$. and dip $6^{\circ}$ to $30^{\circ} \mathrm{NW}$. with an average dip of about $11^{\circ}$ (Conger, 1999). In the western part of the North Penn Area 7 site, a strike of N. $57^{\circ}$ E. with dip of $9^{\circ}$ to $10^{\circ} \mathrm{NW}$. was determined from correlation of beds with elevated natural gamma-ray activity among wells and boreholes (Senior and others, 2008).

\section{Hydrogeologic Setting}

The conceptual model of the groundwater system in the study area consists of dipping, layered fractured rocks with groundwater flow occurring within openings developed primarily along or in the orientation of bedding planes (Senior and Goode, 1999). These openings are either low-angle bedding-plane partings or high-angle fractures and joint sets orthogonal to bedding that form a network parallel to bedding. High-angle or nearly vertical fractures generally do not cut extensively across beds but may provide local routes of groundwater flow or leakage between beds.

Groundwater to depths of probably about $1,000 \mathrm{ft}$ below land surface in the rocks underlying the North Penn Area 7 site originates from infiltration of local precipitation. After infiltrating through soil and saprolite (extensively weathered rock), groundwater moves through near-vertical and bedding-plane fractures in the shale and siltstone bedrock (fig. 5A). Depth to competent bedrock commonly is less than $20 \mathrm{ft}$ below land surface. The soil, saprolite, and individual beds of the sedimentary bedrock form a layered aquifer, with varying degrees of hydraulic connection between the layers. Hydraulic properties of the soil, saprolite, and fracture networks in individual beds of the underlying sedimentary bedrock differ. Primary 


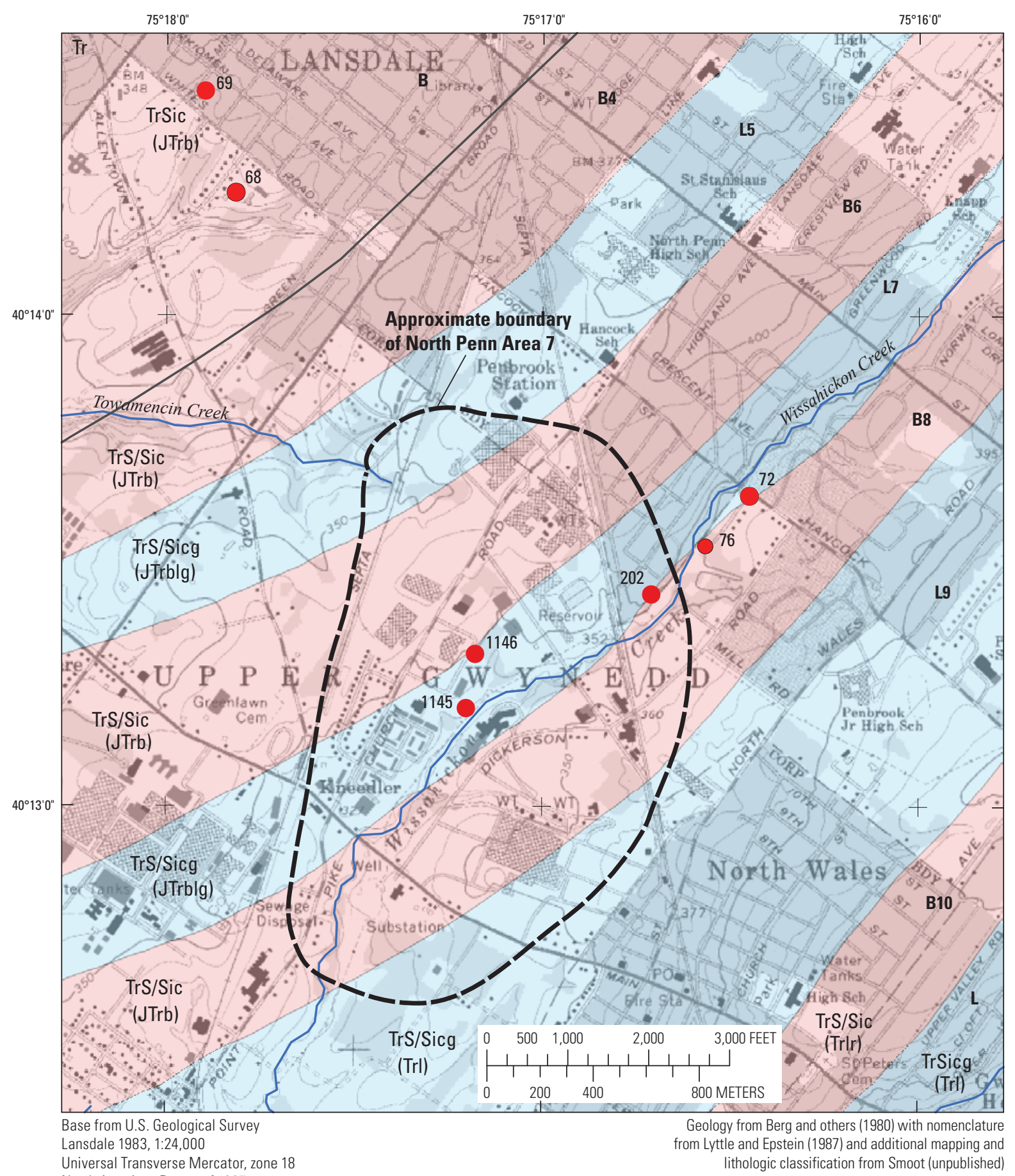

North American Datum of 1927

\section{Nomenclature}

\begin{tabular}{ccc}
$\begin{array}{c}\text { Bed code, } \\
\text { this report }\end{array}$ & $\begin{array}{c}\text { Lyttle and Epstein } \\
\text { (1987) }\end{array}$ & $\begin{array}{c}\text { Smoot } \\
\text { (unpublished) }\end{array}$ \\
\hline B & JTrb & TrSic
\end{tabular}

B4, B6, B8, B10 JTrb, Trlr TrS/Sic

L5, L7, L9 JTrblg, Trl TrS/Sicg

L Trl

Trl TrSicg

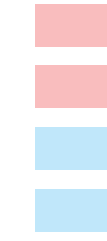

\section{EXPLANATION}

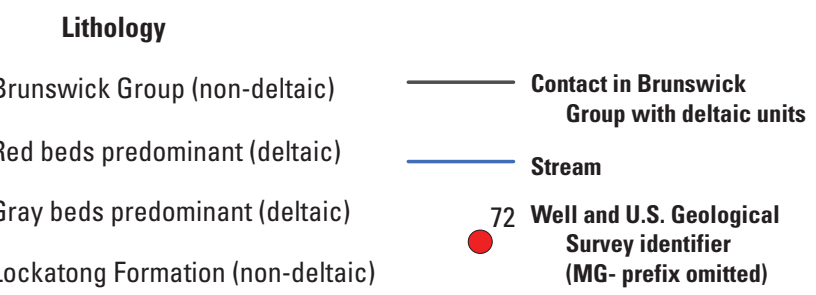

Figure 4. Preliminary revised lithologic mapping of bedrock geology at and near North Penn Area 7 Superfund site, Upper Gwynedd Township and vicinity, Montgomery County, Pennsylvania. 
$\boldsymbol{A}$

NV

SE

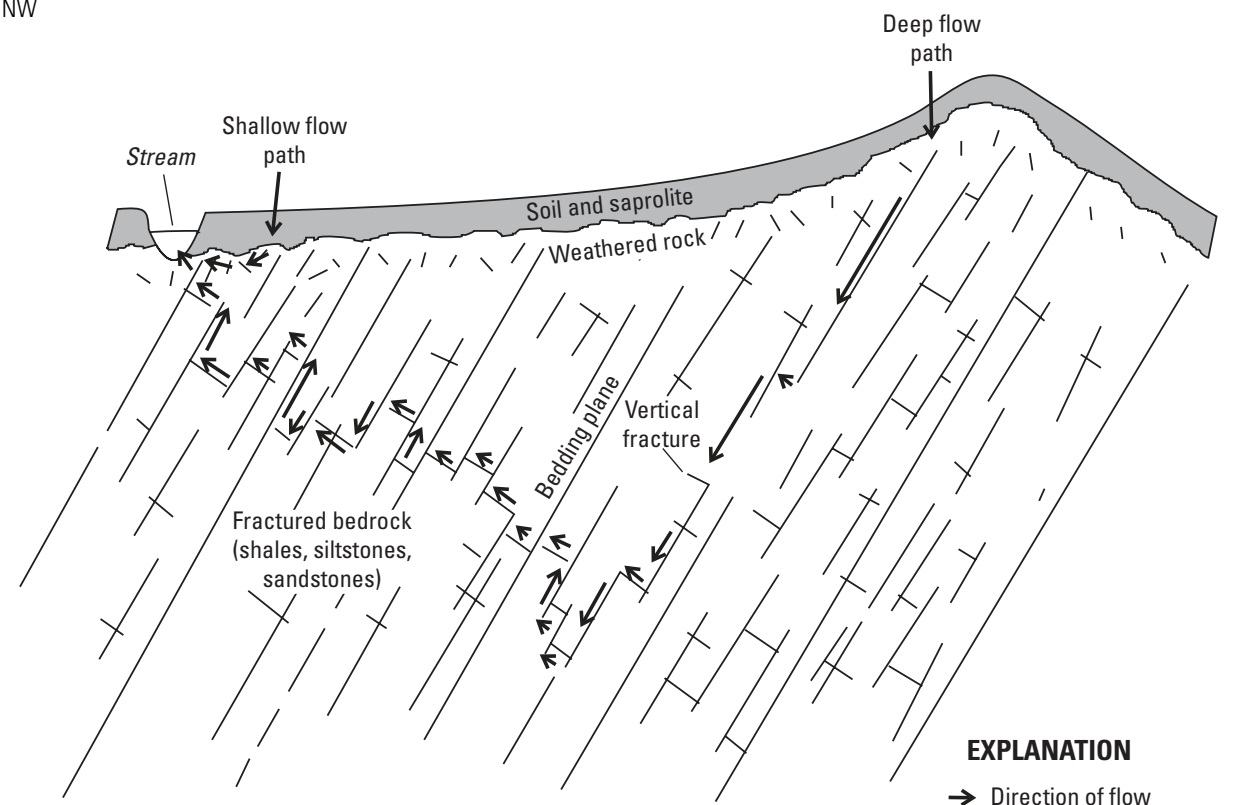

VERTICAL EXAGGERATION

NOT TO SCALE

$\boldsymbol{B}$

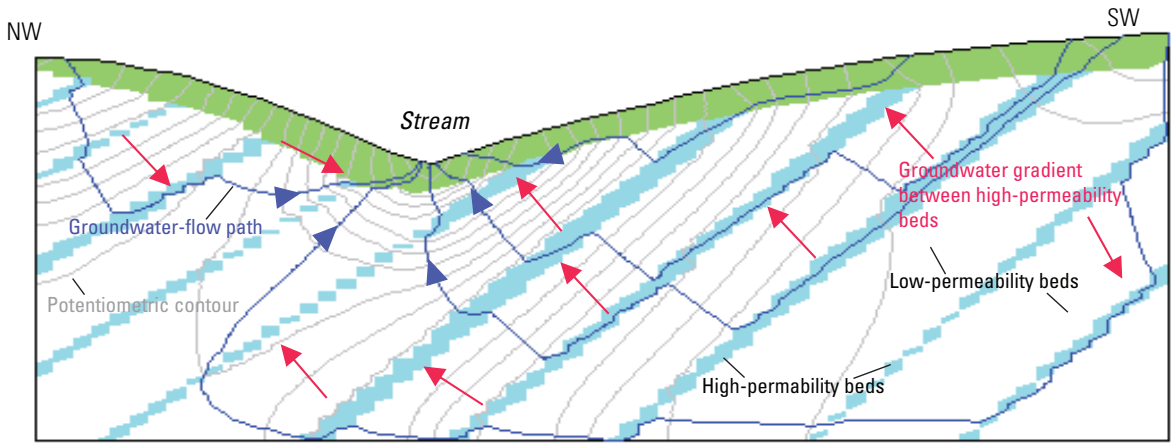

NOT TO SCALE

Figure 5. $A$, Conceptual groundwater-flow system in dipping-bed fractured sedimentary rock aquifer (from Senior and Goode, 1999) and $B$, schematic cross section showing numerical simulation of groundwater flow in conceptual dipping-bed sedimentary rock aquifer with layered units of high and low permeability (modified from Risser and Bird, 2003). 
porosity, permeability, and storage in the Triassic to Jurassic age sedimentary bedrock are very low.

Groundwater in the shallowest part of the sedimentaryrock aquifer may be under unconfined (water-table) or partially confined conditions; the unconfined part of the aquifer probably is thin and is difficult to delineate. In some areas, perched water is present at shallow depths (less than $50 \mathrm{ft}$ ). Groundwater in the deeper part of the aquifer generally is confined or partially confined, resulting in artesian conditions.

Shallow and deep groundwater-flow paths may be present at the site. Generally, groundwater flows in a direction similar to the topographic gradient, although flow paths may be complex, as illustrated by a numerical simulation of the conceptual hydrogeologic setting (fig. $5 \mathrm{~B}$ ). The conceptual simulation shows that, in settings west of the stream, groundwater can flow updip in high permeability layers to discharge to the stream, but in settings east of the stream, groundwater generally flows downdip in high permeability layers to discharge to the stream. Water from the shallow part of the system likely discharges locally to streams or leaks downward to the deeper part of the groundwater-flow system. Deep groundwater discharges to streams or to pumped wells with the natural direction of shallow to deep groundwater flow altered by pumping. Pumping from deep zones may induce downward flow from shallow zones. Cones of depression caused by pumping have been observed to extend preferentially along strike of bedding planes or in the direction of fracture orientation in the Triassic to Jurassic age sedimentary rocks of the Brunswick Group and the Lockatong Formation (Longwill and Wood, 1965). A similar cone of depression associated with pumping at an industrial property (Merck \& Co.) southwest of, and adjacent to, North Penn Area 7 is described by Geraghty \& Miller, Inc. (1993) and Goode and Senior (1998).

The North Penn Area 7 site is on relatively flat terrain that is bisected by Wissahickon Creek. The site extends past the surface-water divide between the Wissahickon Creek Basin and the Towamencin Creek Basin to the west (fig. 3). Church Road (fig. 4) runs along the approximate location of this surface-water divide. The location of the associated groundwater divide, estimated from a map of regional groundwater levels measured in open-hole wells in the vicinity of North Penn Area 7 in December 2000 (Senior and Ruddy, 2004) probably is near the surface-water divide between the Towamencin Creek and Wissahickon Creek Basins.

\section{Summary of Field Investigations of Groundwater System at North Penn Area 7}

Information about the local-scale groundwater system at selected locations at and near North Penn Area 7 was obtained through collection of data in field investigations by USGS and others. Borehole geophysical logging provided data on the distribution of water-bearing zones, vertical gradients, and lithology. Packer tests provided data on the transmissivity and water chemistry of isolated water-bearing intervals, extent of hydraulic connection between isolated aquifer intervals, and vertical gradients. Water levels measured in wells provided data that could be used to determine depth to water from land surface, to evaluate vertical and horizontal gradients, to evaluate relations between groundwater levels and stream gain or loss, and to calibrate the groundwater-flow model. Measurements of streamflow under base-flow conditions provided data to evaluate groundwater/surface-water relations (including identification of gaining and losing reaches of Wissahickon Creek) and to calibrate the groundwater-flow model. Results of each type of data collection effort are summarized in the following sections.

\section{Geophysical Logs}

Geophysical logs were collected in wells at and near North Penn Area 7 to determine the location of water-bearing fractures, direction of vertical borehole flow (and, therefore, presence of vertical hydraulic gradients), and orientation of beds. From 2001 through 2005, USGS collected borehole geophysical logs in 19 existing production and monitor wells and 39 new monitor wells drilled for the RI (table 1; fig. 6) (Senior and others, 2005; 2008). The depths of existing boreholes, including 12 relatively shallow (less than $90-\mathrm{ft}$ deep) monitor wells, 1 deep monitor well, and 6 deep current and former production wells, range from 37.5 to $623 \mathrm{ft}$. depth. The 39 new monitor wells drilled for the RI from 2003 through 2005 were installed in 15 well clusters on the basis of waterbearing zones identified by logs of the first and deepest well in each cluster. The deepest monitor well was initially drilled to a depth of about $300 \mathrm{ft}$ in 11 of the 15 clusters and to depths ranging from 246 to $290 \mathrm{ft}$ in the other four clusters. Shallower wells in the clusters subsequently were drilled to depths ranging from 40 to $230 \mathrm{ft}$. After logging and other testing, all new monitor wells were reconstructed with 20 - to $40-\mathrm{ft}$ screens to isolate water-bearing zones. The number of new monitor wells at each cluster are as follows: one well (2 locations); two wells (2 locations); two wells and reconstruction of an existing well (1 location); three wells (9 locations); and four wells (1 location) (table 1; fig. 6).

Results of geophysical logging show active water-bearing zones occur throughout the aquifer from depths of about 20 to at least $370 \mathrm{ft}$ below land surface (in well MG-151, former Ford 5). Measured directions of vertical borehole flow tended to be upward east of Wissahickon Creek and downward west of Wissahickon Creek or near areas of active pumping. The distribution of vertical gradients indicated by borehole-flow directions was confirmed by water levels measured in isolated zones in packer tests and in well clusters (fig. 7); the distribution of vertical gradients probably is related to the dippingbed structure, except in areas of pumping. Higher heads in deep water-bearing zones than in shallower water-bearing zones can been inferred from a numerical simulation of 
Table 1. Characteristics of wells with geophysical logs collected and aquifer-interval-isolation (packer) tests conducted by the U.S. Geological Survey at and near North Penn Area 7 Superfund site, Upper Gwynedd Township and vicinity, Montgomery County, Pennsylvania, 2000-2005.

[USGS, U.S. Geological Survey; ft, feet; $\mathrm{ft}$ bls, feet below land surface; $\mathrm{T}$, transmissivity; $\mathrm{ft} 2 / \mathrm{d}$, feet squared per day; ft/d, feet per day; --, not available]

\begin{tabular}{|c|c|c|c|c|c|c|c|c|c|c|c|}
\hline $\begin{array}{c}\text { USGS } \\
\text { well } \\
\text { identifier' }\end{array}$ & $\begin{array}{l}\text { Well name } \\
\text { or number }\end{array}$ & $\begin{array}{l}\text { Logged } \\
\text { well } \\
\text { depth } \\
\text { (ft) }\end{array}$ & $\begin{array}{c}\text { Logged } \\
\text { casing } \\
\text { length } \\
\text { (ft) }\end{array}$ & $\begin{array}{l}\text { Casing } \\
\text { diameter } \\
\text { (inches) }\end{array}$ & $\begin{array}{c}\text { Date } \\
\text { logged }\end{array}$ & $\begin{array}{l}\text { Depth to } \\
\text { water on } \\
\text { date of } \\
\text { logging } \\
\text { (ft bls) }\end{array}$ & $\begin{array}{l}\text { Start date } \\
\text { for packer } \\
\text { tests }\end{array}$ & $\begin{array}{c}\text { Depth to } \\
\text { water in } \\
\text { shallowest } \\
\text { interval } \\
\text { in packer } \\
\text { tests } \\
\text { (ft bls) }\end{array}$ & $\begin{array}{c}\text { Number of } \\
\text { isolated } \\
\text { intervals } \\
\text { tested }\end{array}$ & $\begin{array}{l}\text { Total T for } \\
\text { all isolated } \\
\text { intervals } \\
\left(\mathrm{ft}^{2} / \mathrm{d}\right)\end{array}$ & $\begin{array}{c}\text { Total T/ } \\
\text { length of } \\
\text { saturated } \\
\text { open } \\
\text { borehole } \\
\text { (ft/d) }\end{array}$ \\
\hline \multicolumn{12}{|c|}{ Phase 1} \\
\hline 174 & Clearline 2 & 160 & 73 & 6 & $12 / 12 / 00$ & 34.93 & $9 / 17 / 01$ & 31.50 & 6 & 154 & 1.20 \\
\hline 175 & Spra-Fin 1 & 103 & 14 & 6 & $3 / 29 / 02$ & 38.83 & $4 / 22 / 02$ & 36.37 & 3 & 531 & 7.97 \\
\hline 202 & L-22 & 623 & 40 & 12 & $12 / 13 / 01$ & 53.32 & $12 / 19 / 01$ & 45.28 & 4 & 650 & 1.13 \\
\hline 1144 & $\mathrm{~T}-13$ & 84 & 18.5 & 6 & $10 / 12 / 01$ & 31.35 & $11 / 29 / 01$ & 36.09 & 4 & 1,063 & 22.19 \\
\hline 1145 & $\mathrm{~T}-14$ & 83 & 19 & 6 & $10 / 12 / 01$ & 26.80 & $12 / 5 / 01$ & 33.81 & 3 & 306 & 6.22 \\
\hline 1146 & $\mathrm{~T}-4$ & 84.5 & 18.5 & 6 & $10 / 1 / 01$ & 37.33 & $11 / 27 / 01$ & 42.62 & 2 & 48 & 1.15 \\
\hline 1147 & $\mathrm{~T}-11$ & 83.5 & 18 & 6 & $8 / 30 / 01$ & 39.19 & $11 / 15 / 01$ & 48.19 & 2 & 56 & 1.59 \\
\hline 1148 & $\mathrm{~T}-12$ & 84 & 19 & 6 & $10 / 11 / 01$ & 52.48 & -- & -- & -- & -- & -- \\
\hline 1149 & $\mathrm{~T}-10$ & 84 & 18.5 & 6 & $10 / 11 / 01$ & 51.13 & -- & -- & -- & -- & -- \\
\hline 1505 & RW- & 83.2 & 16 & 6 & $10 / 26 / 01$ & 25.94 & -- & -- & -- & -- & -- \\
\hline 1842 & $\mathrm{~T}-15$ & 86 & 18 & 6 & $10 / 10 / 01$ & 41.18 & $11 / 14 / 01$ & 44.90 & 2 & 908 & 22.09 \\
\hline 1843 & $\mathrm{~T}-6$ & 37.5 & 18 & 6 & $10 / 11 / 01$ & 30.30 & -- & -- & -- & -- & -- \\
\hline 1844 & -- & 51.2 & 15 & 6 & $10 / 30 / 01$ & 43.98 & -- & -- & -- & -- & -- \\
\hline 1845 & -- & 54.6 & 19 & 6 & $10 / 30 / 01$ & 44.92 & -- & -- & -- & -- & -- \\
\hline 1846 & -- & 55.9 & 21 & 6 & $10 / 30 / 01$ & 46.19 & -- & -- & -- & -- & -- \\
\hline 1897 & Clearline 3 & 288 & 44 & 10 & $10 / 24 / 01$ & 24.28 & $11 / 7 / 01$ & 27.70 & 4 & 120 & 0.46 \\
\hline \multicolumn{12}{|c|}{ Phase 2} \\
\hline 151 & Ford $\# 5$ & 477 & 86 & 8 & $3 / 26 / 04$ & 25.22 & $3 / 30 / 04$ & 24.81 & 8 & 1,012 & 2.24 \\
\hline 1841 & Spra-Fin 2 & 104 & 17 & 6 & $1 / 24 / 06$ & 23.57 & -- & -- & -- & -- & -- \\
\hline 1920 & Ford MW-1 & 125 & 47 & 6 & $4 / 1 / 04$ & 39.42 & $4 / 21 / 04$ & 40.39 & 3 & 47 & 0.56 \\
\hline 2080 & RI-1D & 299 & 18 & 8 & $5 / 24 / 05$ & 36.85 & $6 / 1 / 05$ & 36.50 & 6 & 707 & 2.69 \\
\hline 2081 & RI-2D & 300 & 18 & 8 & $7 / 12 / 04$ & $\sim 34$ & $7 / 15 / 04$ & 12.35 & 8 & 2,699 & 9.38 \\
\hline 2082 & RI-2I & 188 & 18 & 6 & $8 / 16 / 04$ & 13.04 & -- & -- & -- & -- & -- \\
\hline 2083 & RI-2S & 61 & 17.5 & 6 & $9 / 2 / 2004$ & 9.25 & -- & -- & -- & -- & -- \\
\hline 2084 & RI-3D & 300 & 15 & 8 & $2 / 13 / 04$ & 38.16 & $3 / 5 / 04$ & 38.04 & 10 & 1,779 & 6.79 \\
\hline 2085 & RI-3I & 137 & 18 & 6 & $7 / 24 / 04$ & 42.23 & -- & -- & -- & -- & -- \\
\hline 2086 & RI-3S & 65 & 18.5 & 6 & $7 / 24 / 04$ & 0.68 & -- & -- & -- & -- & -- \\
\hline 2087 & RI-4D & 300 & 25 & 8 & $2 / 20 / 04$ & 24.06 & $4 / 26 / 04$ & 22.91 & 7 & 3,094 & 11.17 \\
\hline 2088 & RI-4I & 137 & 18 & 6 & $7 / 23 / 04$ & 28.07 & -- & -- & -- & -- & -- \\
\hline 2089 & RI-4S & 70 & 19 & 6 & $8 / 3 / 04$ & $\sim 69$ & -- & -- & -- & -- & -- \\
\hline 2090 & RI-5D & 300 & 19 & 8 & $2 / 27 / 04$ & 21.16 & $5 / 17 / 04$ & 20.18 & 9 & 1,908 & 6.82 \\
\hline
\end{tabular}


Table 1. Characteristics of wells with geophysical logs collected and aquifer-interval-isolation (packer) tests conducted by the U.S. Geological Survey at and near North Penn Area 7 Superfund site, Upper Gwynedd Township and vicinity, Montgomery County, Pennsylvania, 2000-2005.-Continued

[USGS, U.S. Geological Survey; ft, feet; ft bls, feet below land surface; T, transmissivity; $\mathrm{ft}^{2} / \mathrm{d}$, feet squared per day; ft/d, feet per day; --, not available]

\begin{tabular}{|c|c|c|c|c|c|c|c|c|c|c|c|}
\hline $\begin{array}{c}\text { USGS } \\
\text { well } \\
\text { identifier }\end{array}$ & $\begin{array}{l}\text { Well name } \\
\text { or number }\end{array}$ & $\begin{array}{l}\text { Logged } \\
\text { well } \\
\text { depth } \\
\text { (ft) }\end{array}$ & $\begin{array}{c}\text { Logged } \\
\text { casing } \\
\text { length } \\
\text { (ft) }\end{array}$ & $\begin{array}{c}\text { Casing } \\
\text { diameter } \\
\text { (inches) }\end{array}$ & $\begin{array}{l}\text { Date } \\
\text { logged }\end{array}$ & $\begin{array}{l}\text { Depth to } \\
\text { water on } \\
\text { date of } \\
\text { logging } \\
\text { (ft bls) }\end{array}$ & $\begin{array}{c}\text { Start date } \\
\text { for packer } \\
\text { tests }\end{array}$ & $\begin{array}{l}\text { Depth to } \\
\text { water in } \\
\text { shallowest } \\
\text { interval } \\
\text { in packer } \\
\text { tests } \\
\text { (ft bls) }\end{array}$ & $\begin{array}{c}\text { Number of } \\
\text { isolated } \\
\text { intervals } \\
\text { tested }\end{array}$ & $\begin{array}{l}\text { Total T for } \\
\text { all isolated } \\
\text { intervals } \\
\left.\text { (ft }{ }^{2} / \mathrm{d}\right)\end{array}$ & $\begin{array}{l}\text { Total T/ } \\
\text { length of } \\
\text { saturated } \\
\text { open } \\
\text { borehole } \\
\text { (ft/d) }\end{array}$ \\
\hline \multicolumn{12}{|c|}{ Phase 2-Continued } \\
\hline 2091 & RI-5I & 98 & 18 & 6 & $7 / 23 / 04$ & 23.68 & -- & -- & -- & -- & -- \\
\hline 2092 & RI-5S & 60 & 18 & 6 & $8 / 4 / 04$ & 21.47 & -- & -- & -- & -- & -- \\
\hline 2093 & RI-6D & 300 & 22 & 8 & $5 / 18 / 04$ & 11.57 & $5 / 24 / 04$ & 9.79 & 9 & 1,518 & 5.23 \\
\hline 2094 & RI-6S & 62 & 18.5 & 6 & $7 / 28 / 04$ & 8.13 & -- & -- & -- & -- & -- \\
\hline 2095 & RI-7D & 246 & 19 & 8 & $2 / 4 / 04$ & 23.58 & $3 / 1 / 04$ & 24.12 & 6 & 2,505 & 11.29 \\
\hline 2096 & RI-7S & 72 & 18 & 6 & $8 / 3 / 04$ & 24.95 & -- & -- & -- & -- & -- \\
\hline 2097 & RI-8D & 300 & 18 & 8 & $7 / 20 / 04$ & 9.22 & $8 / 2 / 04$ & 5.87 & 9 & 4,835 & 16.44 \\
\hline 2098 & RI-8I & 81 & 18 & 6 & $9 / 1 / 04$ & 12.25 & -- & -- & -- & -- & -- \\
\hline 2099 & RI-8S & 40 & 19 & 6 & $9 / 1 / 04$ & 12.58 & -- & -- & -- & -- & -- \\
\hline 2100 & RI-9D & 286 & 19 & 8 & $7 / 16 / 04$ & 54.14 & $7 / 26 / 04$ & 28.29 & 8 & 3,682 & 14.29 \\
\hline 2101 & RI-9I & 188 & 19 & 6 & $9 / 1 / 04$ & $\sim 61.4$ & -- & -- & -- & -- & -- \\
\hline 2102 & RI-9S & 105 & 18 & 6 & $9 / 8 / 04$ & $\sim 67.7$ & -- & -- & -- & -- & -- \\
\hline 2119 & RI-10D & 289 & 19 & 8 & $3 / 12 / 04$ & 39.33 & $3 / 23 / 04$ & 39.19 & 7 & 3,312 & 13.26 \\
\hline 2120 & RI-10I & 140 & 18.5 & 6 & $7 / 29 / 04$ & 42.93 & -- & -- & -- & -- & -- \\
\hline 2121 & RI-10S & 90 & 19 & 6 & $8 / 11 / 04$ & 41.68 & -- & -- & -- & -- & -- \\
\hline 2122 & RI-11D & 299 & 25 & 8 & $7 / 6 / 04$ & 21.62 & $7 / 9 / 04$ & 24.10 & 6 & 601 & 2.19 \\
\hline 2123 & RI-11I & 100 & 18.5 & 6 & $8 / 10 / 04$ & $\sim 21$ & -- & -- & -- & -- & -- \\
\hline 2124 & RI-11S & 60 & 19 & 6 & $9 / 3 / 04$ & 23.94 & -- & -- & -- & -- & -- \\
\hline 2125 & RI-12D & 300 & 20 & 8 & $3 / 3 / 04$ & 43.68 & $4 / 6 / 04$ & 41.41 & 8 & 515 & 1.99 \\
\hline 2126 & RI-13D & 279 & 20 & 8 & $5 / 25 / 04$ & 24.61 & $6 / 8 / 04$ & 25.72 & 7 & 6,081 & 24.01 \\
\hline 2127 & RI-13I & 138 & 19 & 6 & $9 / 3 / 04$ & 27.28 & -- & -- & -- & -- & -- \\
\hline 2128 & RI-13S & 75 & 18 & 6 & $8 / 12 / 04$ & 27.75 & -- & -- & -- & -- & -- \\
\hline 2129 & RI-14D & 299 & 54 & 8 & $6 / 1 / 05$ & 43.51 & $6 / 16 / 05$ & 43.52 & 4 & 757 & 2.96 \\
\hline 2130 & RI-14S & 118 & 56 & 6 & $7 / 20 / 05$ & 46.01 & -- & -- & -- & -- & -- \\
\hline 2131 & RI-15DD & 299 & 18 & 8 & $5 / 25 / 05$ & 39.34 & $6 / 9 / 05$ & 39.75 & 7 & 1,109 & 4.28 \\
\hline 2132 & RI-15DD & 220 & 17 & 6 & $7 / 14 / 05$ & 41.94 & -- & -- & -- & -- & -- \\
\hline 2133 & RI-15I & 130 & 18 & 6 & $7 / 14 / 05$ & 41.09 & -- & -- & -- & -- & -- \\
\hline 2134 & RI-15S & 100 & 18 & 6 & $7 / 20 / 05$ & 40.53 & -- & -- & -- & -- & -- \\
\hline
\end{tabular}

${ }^{1}$ MG- prefix omitted. 


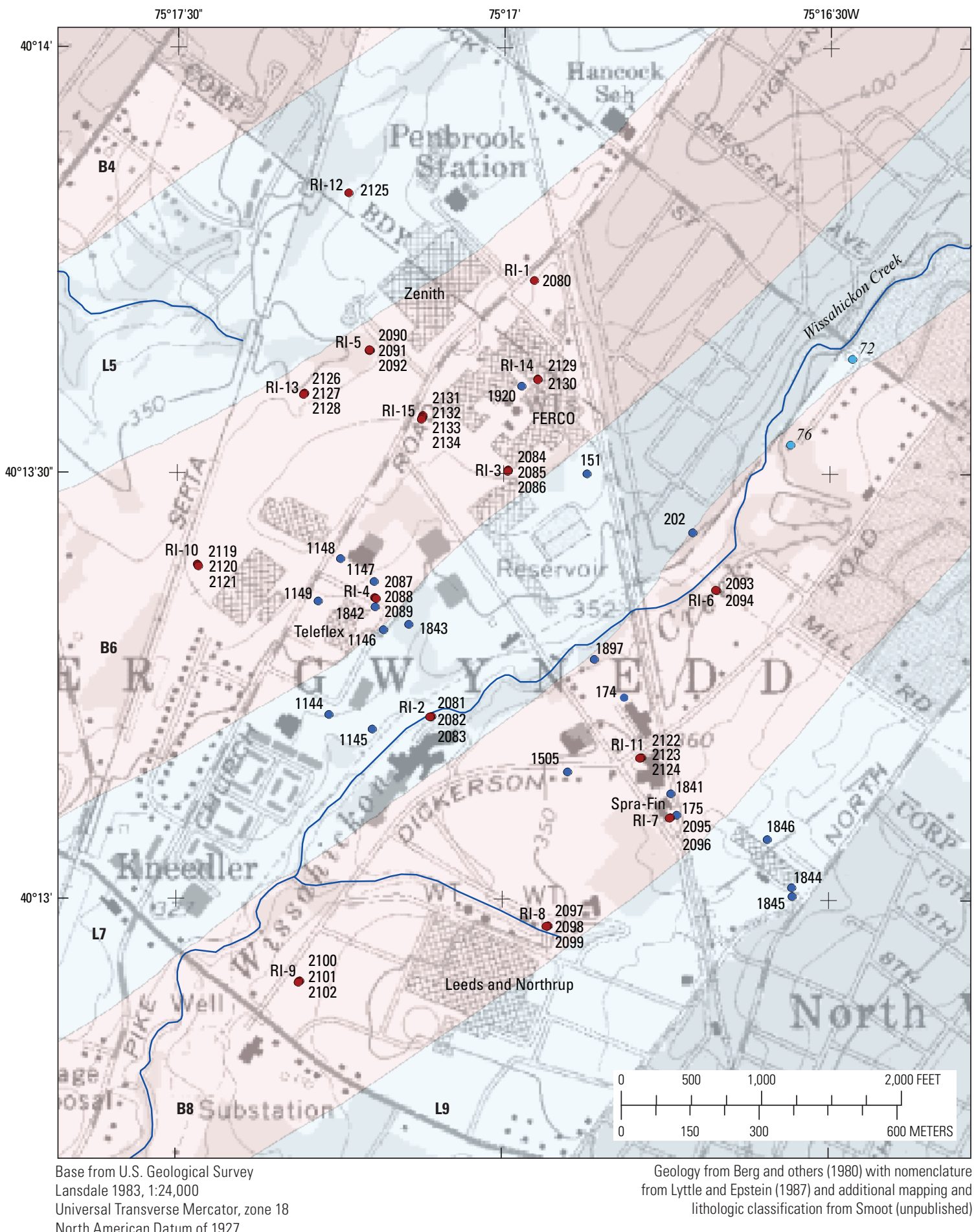

Universal Transverse Mercator, zone 18

Bed code,

EXPLANATION

\begin{tabular}{|c|c|}
\begin{tabular}{c|c} 
Bed code, \\
this report
\end{tabular} & Lithology \\
\hline B, B4-B8 & Red beds predominant \\
\hline L5-L9 & Gray beds predominant \\
\hline
\end{tabular}

Well and U.S. Geological Survey identifier (MG- prefix omitted), well cluster identifier (RI-), and dates of logging for-

1897. Existing well, 2001-06

RI-7 $e^{2095}$ New monitor well and cluster, 2004-05

76 Existing well, 1995-96

Figure 6. Location of existing and new monitor wells with geophysical logs and packer tests conducted by U.S. Geological Survey at and near the North Penn Area 7 Superfund site, Upper Gwynedd Township and vicinity, Montgomery County, Pennsylvania, 2000-2005. (See table 1 for list of wells with packer tests.) 


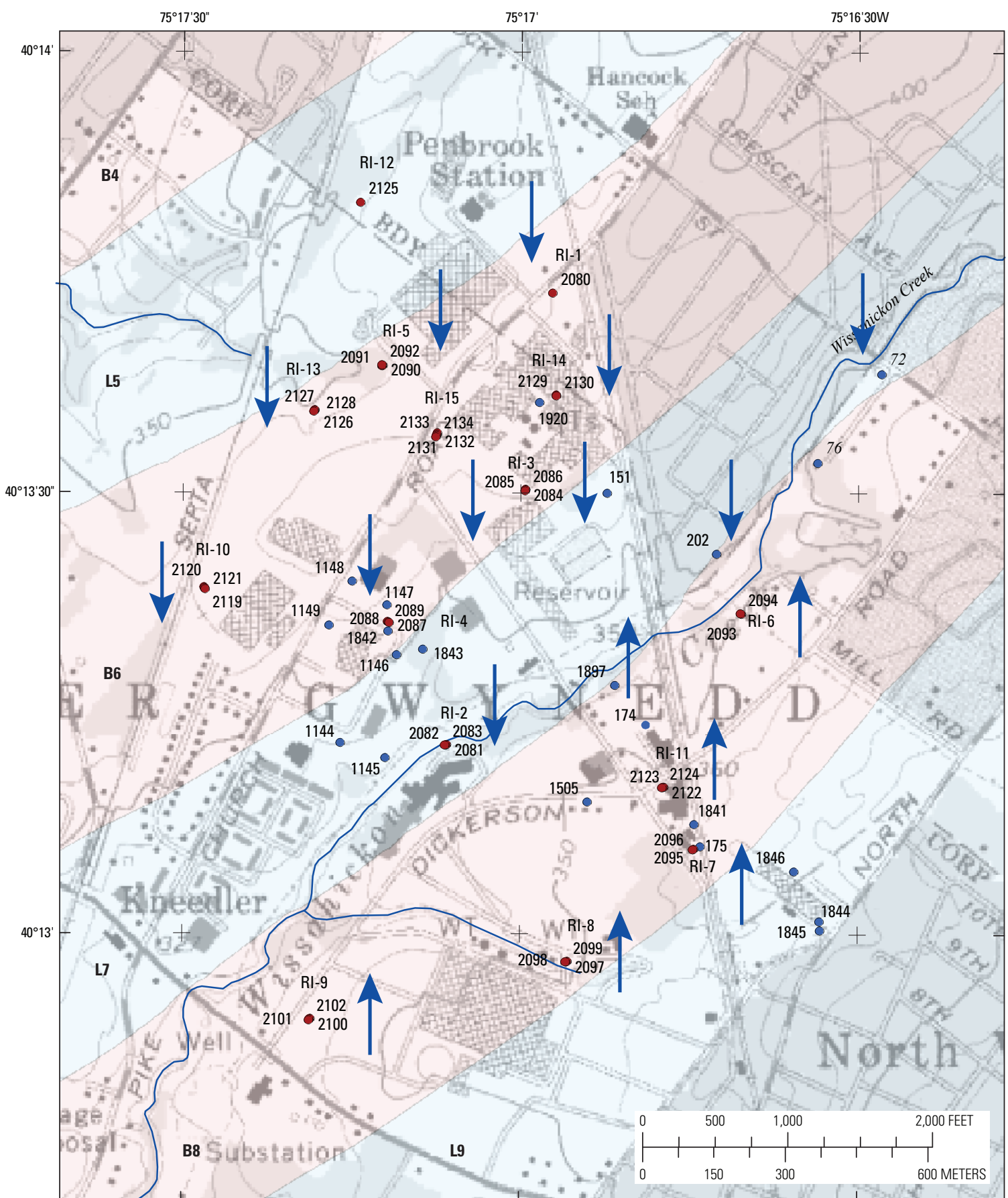

Base from U.S. Geological Survey

Lansdale 1983, 1:24,000

Universal Transverse Mercator, zone 18

North American Datum of 1927

\begin{tabular}{c|c} 
Bed code & Lithology \\
\hline B, B4-B8 & Red beds predominant \\
\hline L5-L9 & Gray beds predominant
\end{tabular}

\section{EXPLANATION}

Well and U.S. Geological Survey identifier (MG- prefix omitted) well cluster identifier (RI-), and dates of logging for-

1897 Existing well, 2001-06

RI-7 2095 New monitor well and cluster, 2004-05

76 Existing well, 1995-96
Geology from Berg and others (1980) with nomenclature from Lyttle and Epstein (1987) and additional mapping and lithologic classification from Smoot (unpublished)

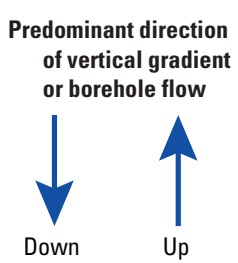

Figure 7. Direction of vertical gradients measured in boreholes and (or) determined from water levels in well clusters at and near North Penn Area 7 Superfund site, Upper Gwynedd Township and vicinity, Montgomery County, Pennsylvania, 2001-2005. 
groundwater-flow paths in a conceptual model of the geologic setting (fig. $5 B$ )

The borehole geophysical logs show the presence of relatively thin (less than 15 -ft thick) zones with elevated natural gamma-ray activity that can be correlated between wells and that can be used to estimate sedimentary bed orientation (Senior and others, 2005; 2008). Bedding generally strikes northeast and dips about 10 degrees to the northwest in the vicinity of North Penn Area 7, although the dip angle may not be uniform throughout the area as a result of minor faulting. Reported estimates of the dip angle range from about 6 to 12 degrees at and near the location of North Penn Area 7 (Longwill and Wood, 1965; Conger, 1999; Senior and others, 2005; 2008). The relatively thin zones of elevated natural gamma-ray activity commonly are associated with dark gray to black sedimentary layers in the central and western part of North Penn Area 7 site (fig. 8), which probably are lake deposits that are laterally continuous over several thousands of feet. Although zones of elevated natural gamma-ray activity were measured in wells logged in the eastern part of North Penn Area 7 (east from Wissahickon Creek), these zones could be correlated to similar zones on logs in nearby wells, such as in well clusters that were less than $100 \mathrm{ft}$ apart, but did not appear to correlate between logs of wells more than about $300 \mathrm{ft}$ apart. The apparent lack of correlation of zones with elevated natural gamma-ray activity between wells more than a few hundred $\mathrm{ft}$ apart in the eastern part of North Penn Area 7 may be related to changes in the sedimentary environment that either limited or disrupted lateral continuity. In addition, lithologic differences across the site are inferred from an apparent greater abundance of coarser bedded material, as indicated by single-point resistance logs, in wells in the eastern part of the study area than in wells in the western part of the study area. The lithologic characteristics in the eastern part of the study area may be attributed to the presence of deltaic deposits mapped by Smoot (Joseph P. Smoot, U.S. Geological Survey, written commun., 2005).

Single-point resistance logs for deep (300 ft) wells separated by hundreds to thousands of feet were correlated in the western part of North Penn Area 7, as was done with the natural gamma-ray logs. Correlations of elevated resistance among well logs indicate laterally continuous deposits of probable relatively coarser-grained sediments (siltstone or sandstone). In the central to eastern part of the study area, only a few thick zones of high resistivity that are probably indicative of sandstone beds could be correlated among wells (Senior and others, 2005); the zones do not appear to be laterally continuous over distances of more than a few hundred feet.

In the monitor well clusters throughout the study area, correlation of natural gamma-ray and single-point resistance $\operatorname{logs}$ indicate that bedding is laterally continuous over the small horizontal distances (typically less than $30 \mathrm{ft}$ ) between the deep, intermediate, and shallow wells. Examples of logs showing interpreted lithologic correlations in monitor-well clusters in the western (RI-15 cluster) and eastern (RI-8 cluster) parts of North Penn Area 7 are shown in figure 9.

\section{Aquifer Tests}

Packer tests of single wells provided information about local-scale hydraulic properties and water chemistry of isolated intervals of the aquifer. Aquifer tests involving a pumping well with multiple observation wells provided information about hydraulic properties over a larger area around the tested well than the single-well packer tests.

\section{Single-Well Packer Tests}

Packer tests were conducted by USGS in wells at and near North Penn Area 7 to obtain hydraulic and water-quality data in isolated intervals of the aquifer. During these singlewell tests, individual water-bearing zones, consisting of one or more fractures, were isolated by use of straddle packers to obtain hydraulic information, such as the extent of hydraulic connection between isolated intervals and transmissivity and hydraulic heads in isolated zones, and to obtain water samples to estimate the vertical distribution of contaminants and water-quality characteristics. Tests were conducted on a total of 152 intervals in 26 wells ranging in depth from 85 to $622 \mathrm{ft}$ ( 9 wells in phase 1 and 17 wells in phase 2 of field investigations) (Senior and others, 2005; 2008). Water-quality data for zones isolated by packers are discussed in the section "Groundwater Quality in Isolated Intervals" farther on in this report.

Methods used for single-well packer tests done at North Penn Area 7 by USGS are explained in previous reports (Senior and others, 2005; 2008). Water-bearing intervals selected for testing typically were isolated by packers placed about 20 to $30 \mathrm{ft}$ apart. The transmissivity of each interval was calculated from pumping and drawdown data. The transmissivity $(\mathrm{T})$ values when divided by the thickness of the isolated interval can be converted to hydraulic conductivity (K).

Results of packer tests revealed that isolated intervals had little to no vertical hydraulic connection to adjacent intervals, as indicated by differences in hydraulic heads in isolated intervals after packer inflation and little water-level response in adjacent isolated intervals to pumping of the isolated interval. For example, water-level responses in the isolated interval of 193 to $215 \mathrm{ft}$ below land surface and adjacent intervals in well MG-2131 (RI-15DD; fig. 10) were typical of many isolated zones tested in most wells. The differences in hydraulic heads after packer inflation under static conditions generally confirmed the direction of vertical gradients indicated by borehole flow measured during logging. These findings support the conceptual model of a leaky layered aquifer where water-bearing layers, typically less than $20 \mathrm{ft}$ in thickness, are separated by low-permeability layers that vary in thickness.

Because of similarity in depth and diameter, the hydraulic properties from 15 deep monitor wells were could be compared without bias for those characteristics across North Penn Area 7. Transmissivity values calculated from pumping rates and drawdown in the isolated intervals in the 15 deepest new monitor wells ranged over three orders of magnitude (2.8 to 


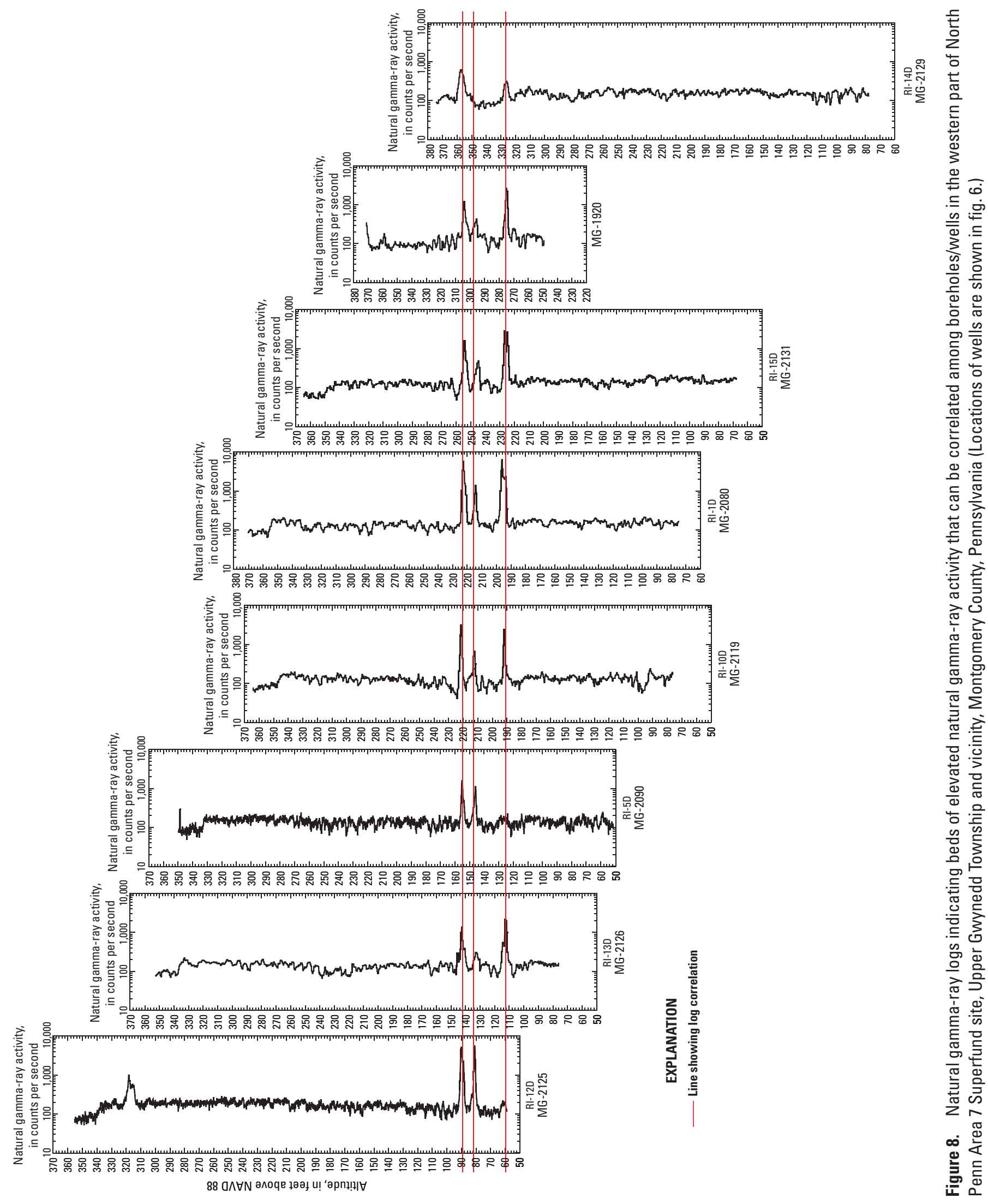




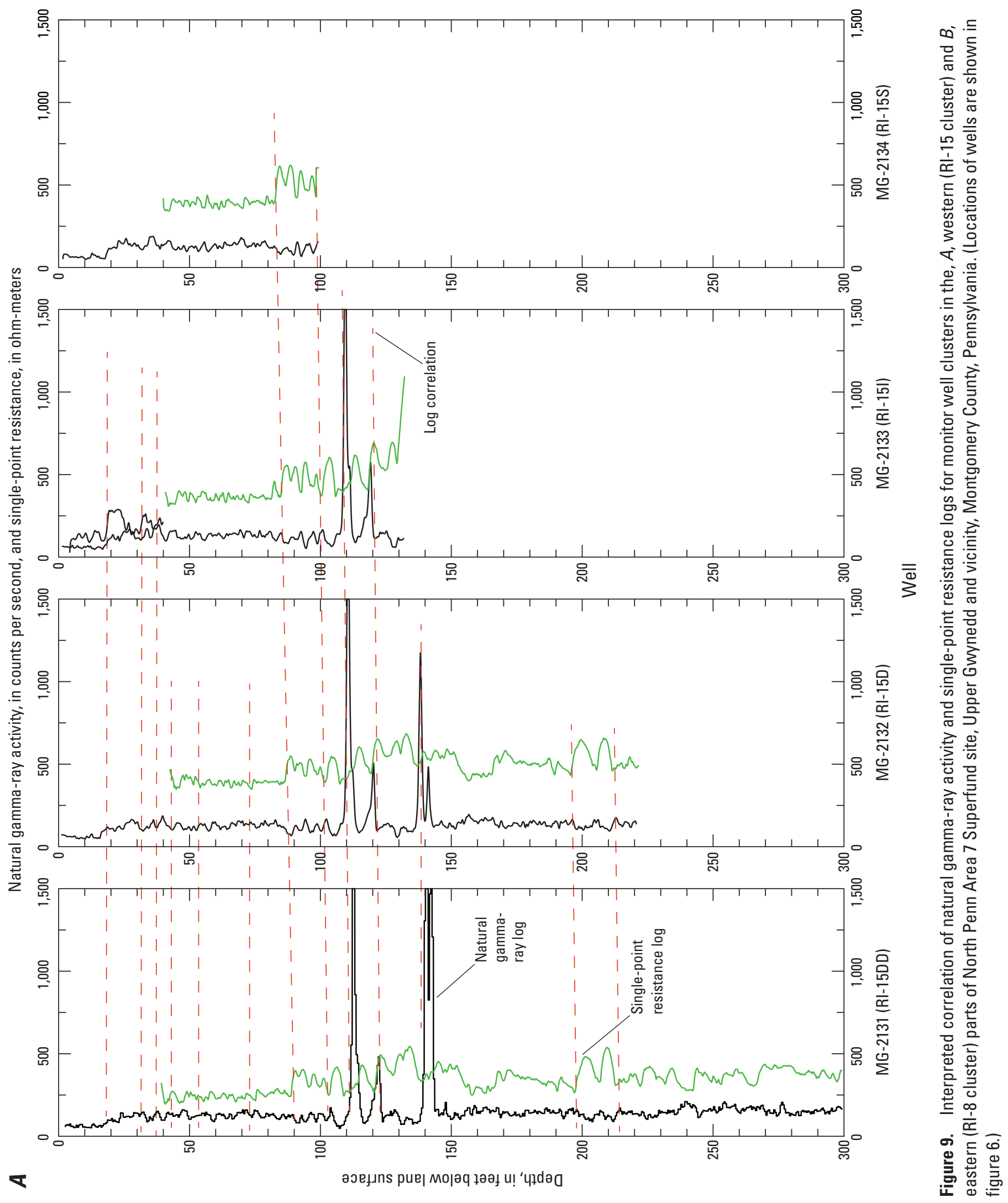



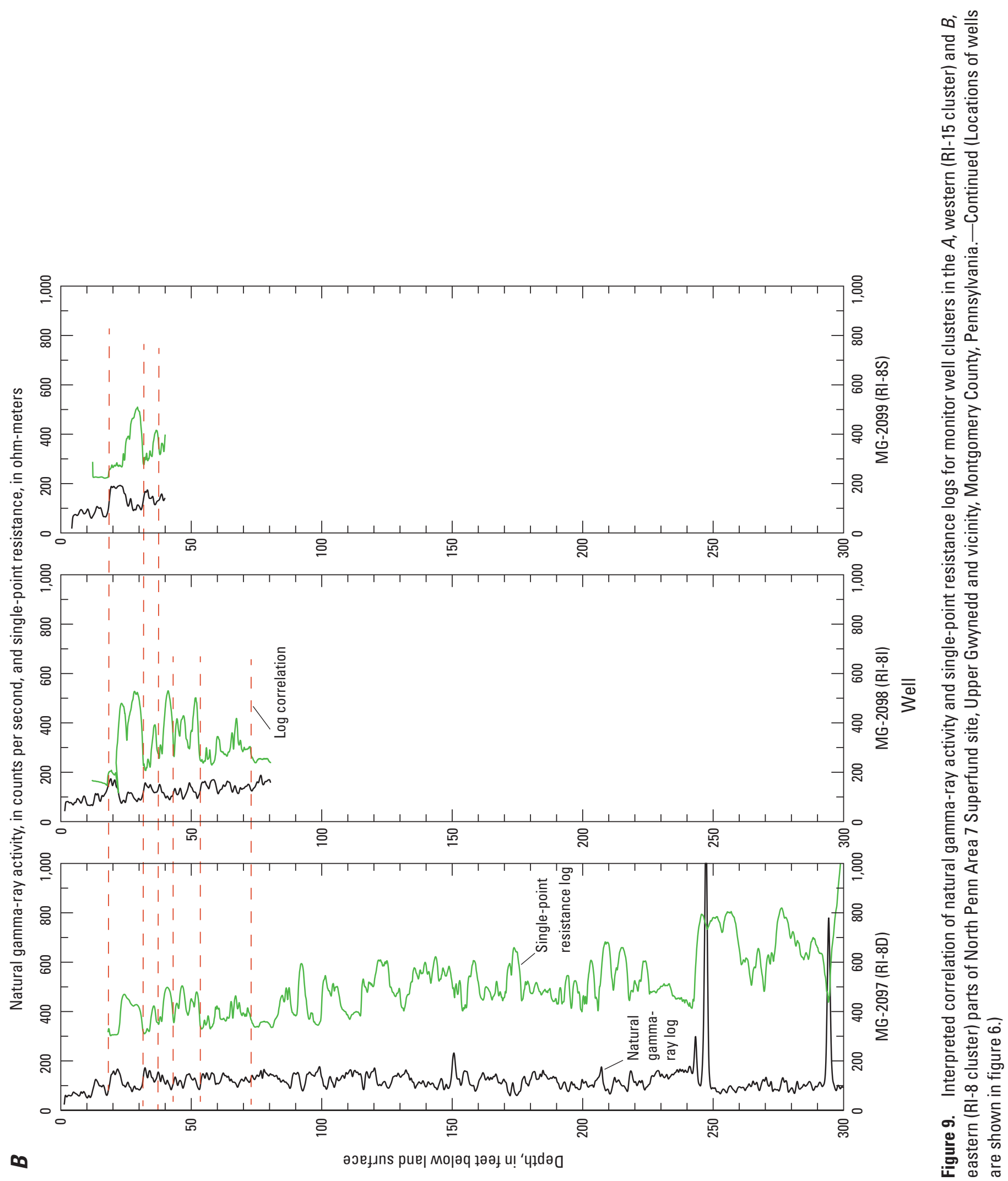


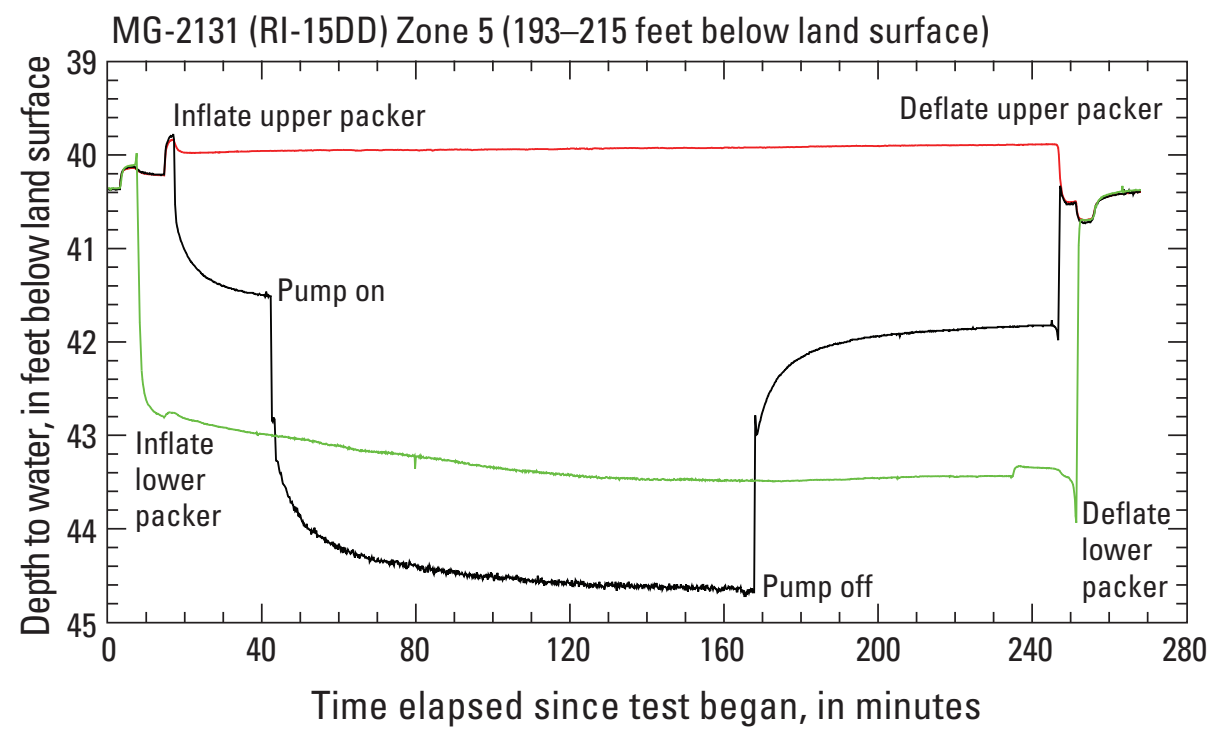

EXPLANATION

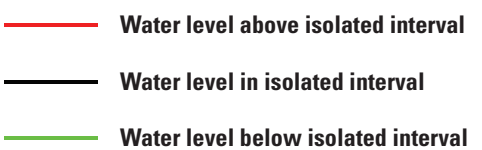

Figure 10. Water levels in the isolated interval of 193 to $215 \mathrm{ft}$ below land surface and adjacent intervals in well MG-2131 (RI-15DD) during the single-well packer tests, North Penn Area 7 Superfund site, Upper Gwynedd Township and vicinity, Montgomery County, Pennsylvania, June 10, 2005.

2,290 $\mathrm{ft}^{2} / \mathrm{d}$ ) (Senior and others, 2008). These transmissivity values, however, showed some relation to depth over the range of depths tested, although the full range of transmissivities was measured throughout the $300-\mathrm{ft}$ thickness of the aquifer. When transmissivities of tested intervals were grouped by depth in ranges of $50 \mathrm{ft}$ (fig. 11A), the transmissivities of the shallowest zones and deepest zones tested (interval midpoints of 0 to 50 and 251 to $300 \mathrm{ft}$ below land surface, respectively) were statistically significantly different (smaller) from transmissivities of intermediate depths, as determined by the non-parametric Kruskall-Wallis test using a p-value of 0.05 (statistically significant at a 95-percent confidence level). Transmissivities of tested zones at intermediate depths (interval midpoints ranging from 51 to $250 \mathrm{ft}$ below land surface) were statistically similar to each other. The hydraulic conductivity of tested intervals, calculated by dividing transmissivity by the length of the tested interval, shows the same relation to depth as transmissivity (fig. 11B). Results of the evaluation of differences in transmissivity with depth suggests that weathering may reduce the permeability of the shallowest interval tested ( 0 to $50 \mathrm{ft}$ below land surface) and that the frequency of high-permeability zones decreases with depth below $250 \mathrm{ft}$. The transmissivities of water-bearing zones in the existing production and monitor wells tested mostly during phase 1 of field activities (Senior and others, 2005) ranged from 1.2 to $795 \mathrm{ft}^{2} / \mathrm{d}(0.11$ to $146 \mathrm{~m}^{2} / \mathrm{d}$ ) and were similar to those determined for the $15 \mathrm{new}$ deep monitor wells. Transmissivities of tested zones for deep monitor and existing production wells are shown in a crosssection (fig. 12) where well locations have been projected onto the section line oriented in the dip direction.

Transmissivities and associated hydraulic conductivities of individual tested zones did not differ statistically by geologic unit (fig. 13A), as determined by the non-parametric Kruskall-Wallis test using a p-value of 0.05 . These hydraulic properties ranged over the same three orders of magnitude for the four geologic units with more than four water-bearing zones tested. Mean and median values of hydraulic conductivity determined in packer tests of individual isolated zones in geologic units ranged from 5.7 to $18.4 \mathrm{ft} / \mathrm{d}(1.7$ to $5.6 \mathrm{~m} / \mathrm{d})$ and 3.0 to $5.1 \mathrm{ft} / \mathrm{d}(0.9$ to $1.6 \mathrm{~m} / \mathrm{d})$, respectively (fig. $13 B)$. Estimates of bulk or average hydraulic conductivity for geologic units calculated by dividing the total transmissivity of waterbearing zones by the total open interval of the geologic unit intersected by a borehole were slightly less than average of the hydraulic conductivities determined for individual zones because the bulk calculation included very low permeability sections of the aquifer that were not tested with packers. For data collected from the 15 new deep monitor wells, bulk hydraulic conductivity ranged from 0.1 to $26.4 \mathrm{ft} / \mathrm{d}(0.03$ to $8.0 \mathrm{~m} / \mathrm{d}$ ), and average estimates of bulk conductivity for geologic units L5, B6, L7, B8, L9 were 3.7, 8.8, 7.6, 5.2, and $9.4 \mathrm{ft} / \mathrm{d}(1.1,2.7,2.3,1.6$, and $2.9 \mathrm{~m} / \mathrm{d})$, respectively. 

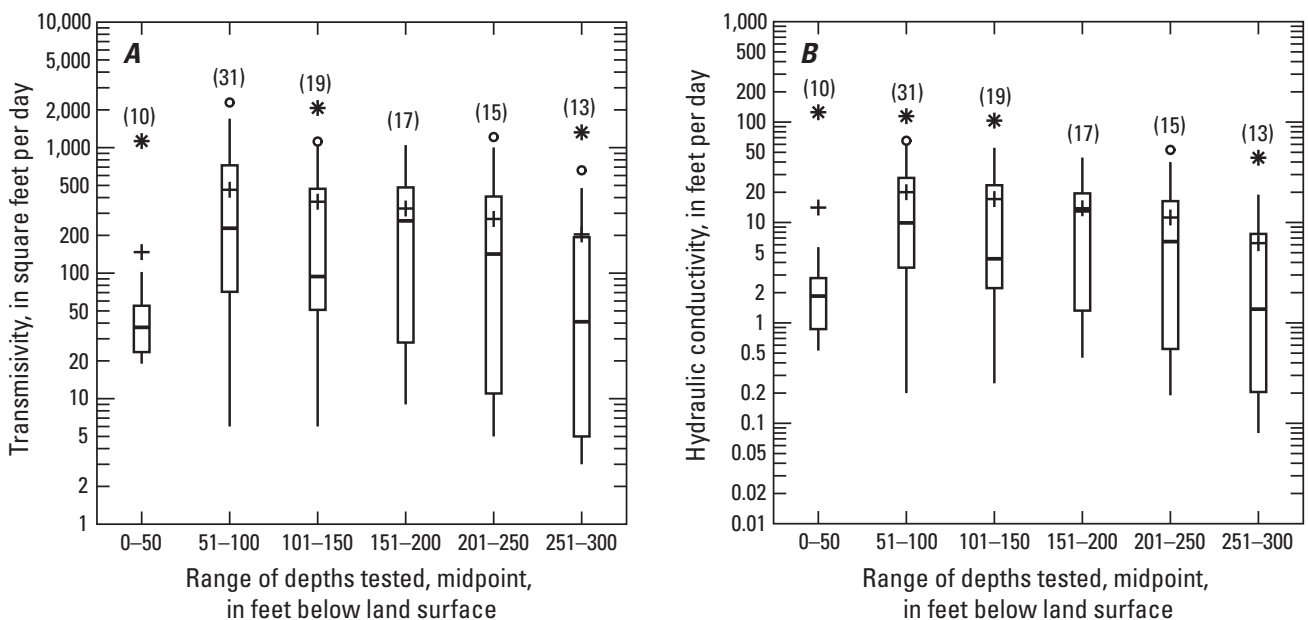

EXPLANATION

(31) Number of values

+ $\begin{aligned} & \text { 75th percentile } \\ & \text { 50th percentile (median) } \\ & \text { Mean }\end{aligned} \begin{gathered}\text { Interquartile } \\ \text { range }\end{gathered}$

+ Mean

25th percentile range

- Outside value-Values are more than 1.0 times the interquartile range from the top to bottom of the box

* Far-out value-Values are more than 1.5 times the interquartile range from the top to bottom of the box

Figure 11. $A$, calculated transmissivities and $B$, hydraulic conductivities in relation to a range of depths for water-bearing intervals isolated by packers in 15 wells of similar depths, North Penn Area 7 Superfund site, Upper Gwynedd Township and vicinity, Montgomery County, Pennsylvania, March 2004 through August 2005. Wells ranging in depth from 246 to 300 feet (new monitor wells RI-1D to RI-15DD) were initially drilled as the deepest borehole in a monitor-well cluster.

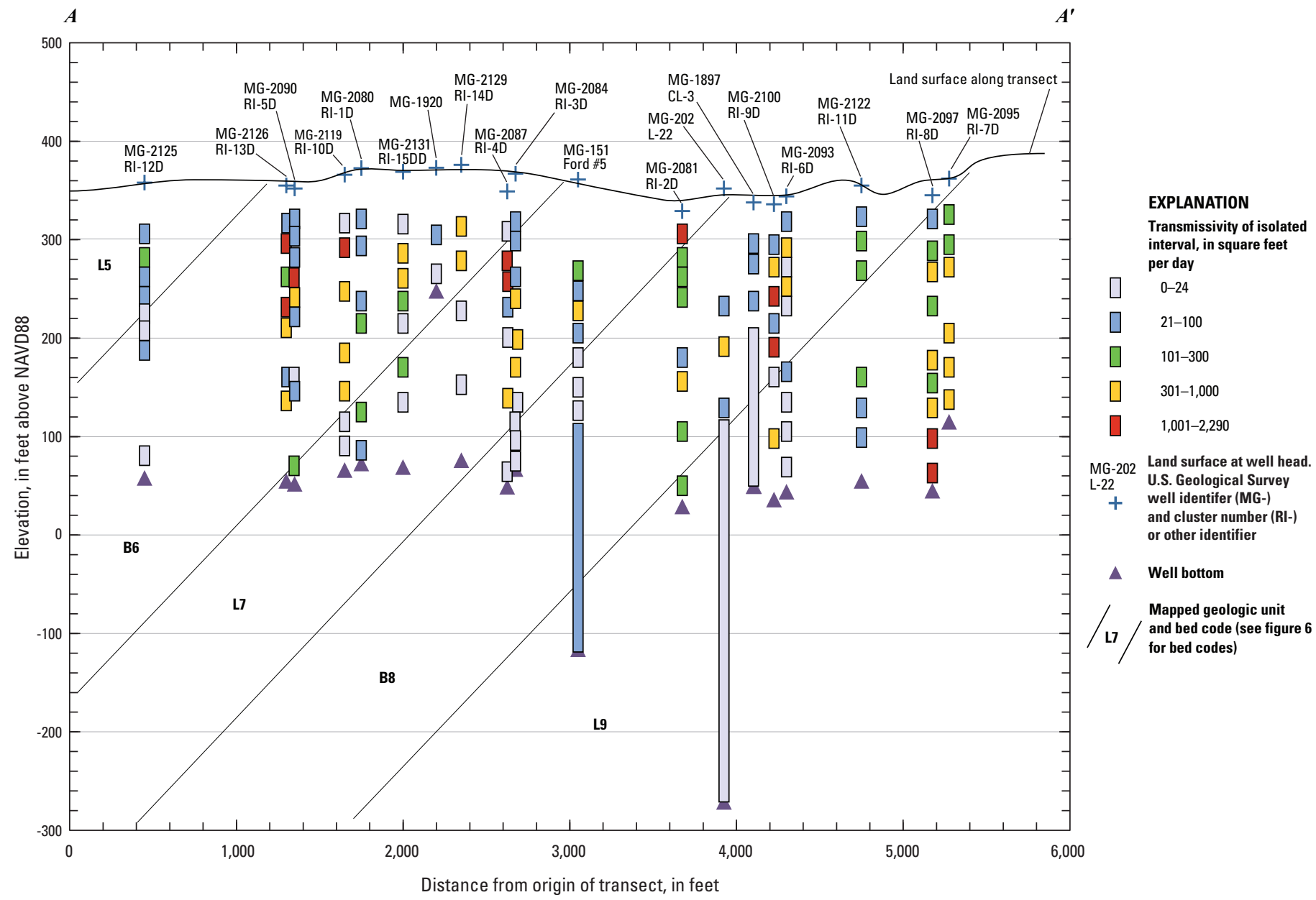

Figure 12. Section $A-A^{\prime}$ with transmissivity of tested zones in selected wells that are projected onto a line approximately parallel to estimated dip of 10 degrees, North Penn Area 7 Superfund site, Upper Gwynedd Township and vicinity, Montgomery County, Pennsylvania. (See figure 6 for explanation of bed codes and figure 14 for location of section line.) 

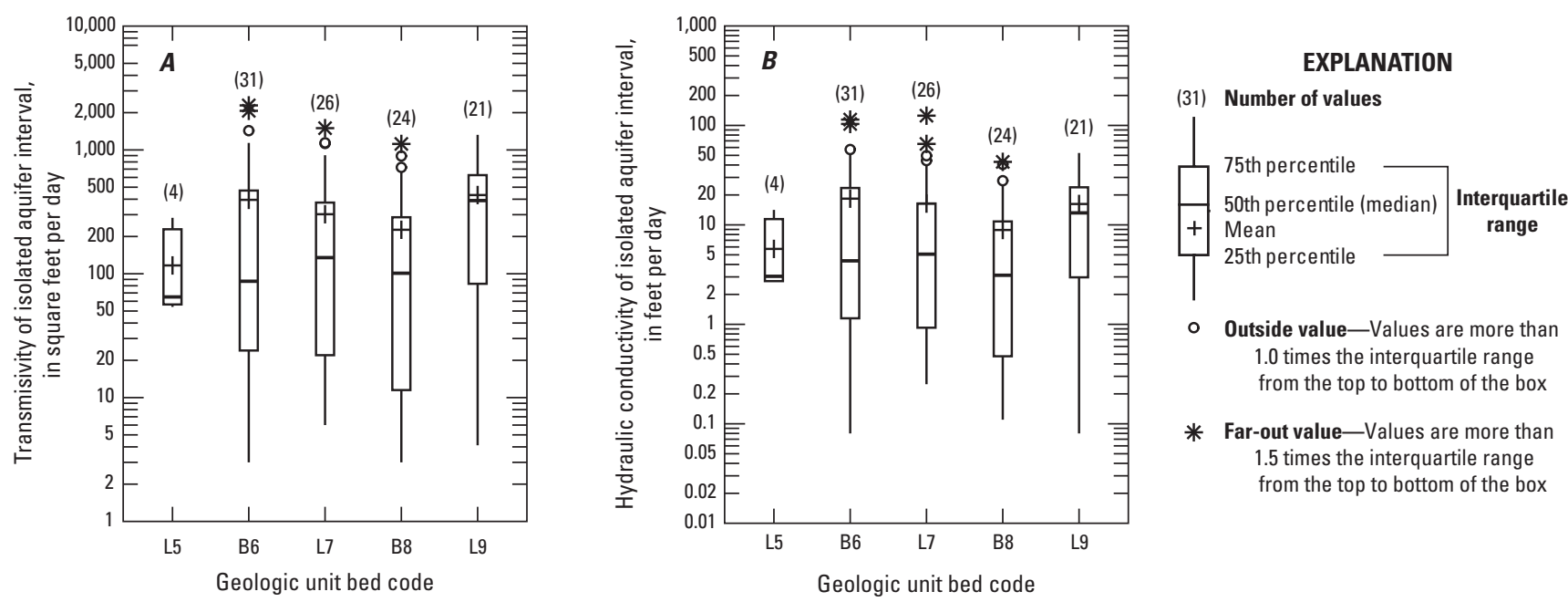

Figure 13. A, calculated transmissivities and $B$, hydraulic conductivities, by mapped geologic unit, for water-bearing intervals isolated by packers in 15 wells of similar depths, North Penn Area 7 Superfund site, Upper Gwynedd Township and vicinity, Montgomery County, Pennsylvania, March 2004 through August 2005. Wells ranging in depth from 246 to 300 feet (RI-1D to RI-15DD) were initially drilled as the deepest boreholes in monitor-well clusters. (See figures 4 and 6 for explanation of geologic unit bed codes.)

\section{Multiple-Well Aquifer Tests}

In 2002 and 2004, the production well MG-202 (L-22) (fig. 2) was shut down for periods of a few days, providing an opportunity to measure water-level response in nearby wells to the shutdown and restart of pumping. Data collected for these shutdown tests at multiple observation wells are presented in detail by Senior and others (2005) and Senior and others (2008). Locations of pumped and observation wells used for these tests are shown in figure 14 . The 623 - $\mathrm{ft}$ deep production well MG-202 (L-22) was pumped at rates from about 75 to 125 gallons per minute (gal $/ \mathrm{min})$ during routine operation. The primary purpose of the tests was to determine the spatial distribution of hydraulic responses rather than to estimate aquifer properties of transmissivity and storage. However, drawdown and recovery data for observation wells obtained during the two tests were analyzed by use of Theis (1935) solution for confined aquifers, a method that is not strictly appropriate for these dipping-bed fractured-rock leaky aquifers but was considered useful as a first approximation and to evaluate the extent of deviation from the Theis solution. This analysis yielded estimates of transmissivity that ranged from 712 to $2,286 \mathrm{ft}^{2} / \mathrm{d}\left(66\right.$ to $\left.212 \mathrm{~m}^{2} / \mathrm{d}\right)$ and of storage that ranged from 0.00003 to 0.0071 (Senior and others, 2005; 2008).

Wells that responded to changes in pumping of well MG-202 (L-22) generally were along strike or open to the projected dip of the thickness of aquifer intersected by waterproducing zones in well MG-202 (L-22). Water levels in wells that were open to the structurally projected thickness of the main producing interval of well MG-202 (L-22), located from 53 to $260 \mathrm{ft}$ below land surface with the main producing zone at about $150 \mathrm{ft}$ below land surface, reflected changes in pumping at well MG-202 (L-22), whereas water levels in wells that were not open to the structurally projected thickness of the main producing interval in well MG-202 (L-22) did not reflect changes during the 2002 or the 2004 shutdown tests (fig. 15). The changes in water levels shown on figure 15 were not corrected for changes in background water levels, which were $+0.10 \mathrm{ft}$ (rise) and $-0.44 \mathrm{ft}$ (decline), respectively, for the March 2002 and December 2004 tests in background well MG-68. The schematic cross-sections (fig. 15) assume a dip angle of 10 degrees to the northwest and depict the general pattern of wells that respond to pumping in well MG-202 (L-22). However, the dip angle may not be uniform throughout the area as a result of minor faulting. Previous estimates of the dip angle determined from log correlation range from about 6 to 10 degrees in the area (Conger, 1999; Senior and others, 2005; 2008); therefore, actual bedding planes of geologic units may differ from those shown in this schematic and other cross sections presented in this report.

A pattern of water-level responses, indicating similar structural/stratigraphic controls on hydraulic connections, was observed in nearby wells during the June 2005 packer test of the deep well MG-2131 (RI-15DD) when water-levels were monitored in wells MG-2085 (RI-3I), MG-2084 (RI-3D), MG-2092 (RI-5S), MG-2091 (RI-5I), MG-2090 (RI-5D), and MG-2126 (RI-13D) (fig. 16). These data, which are not presented in previous reports, show that only well MG-2090 (RI-5D), which is open downdip from the tested isolated interval at 193 to $215 \mathrm{ft}$ below land surface in well MG-2131 


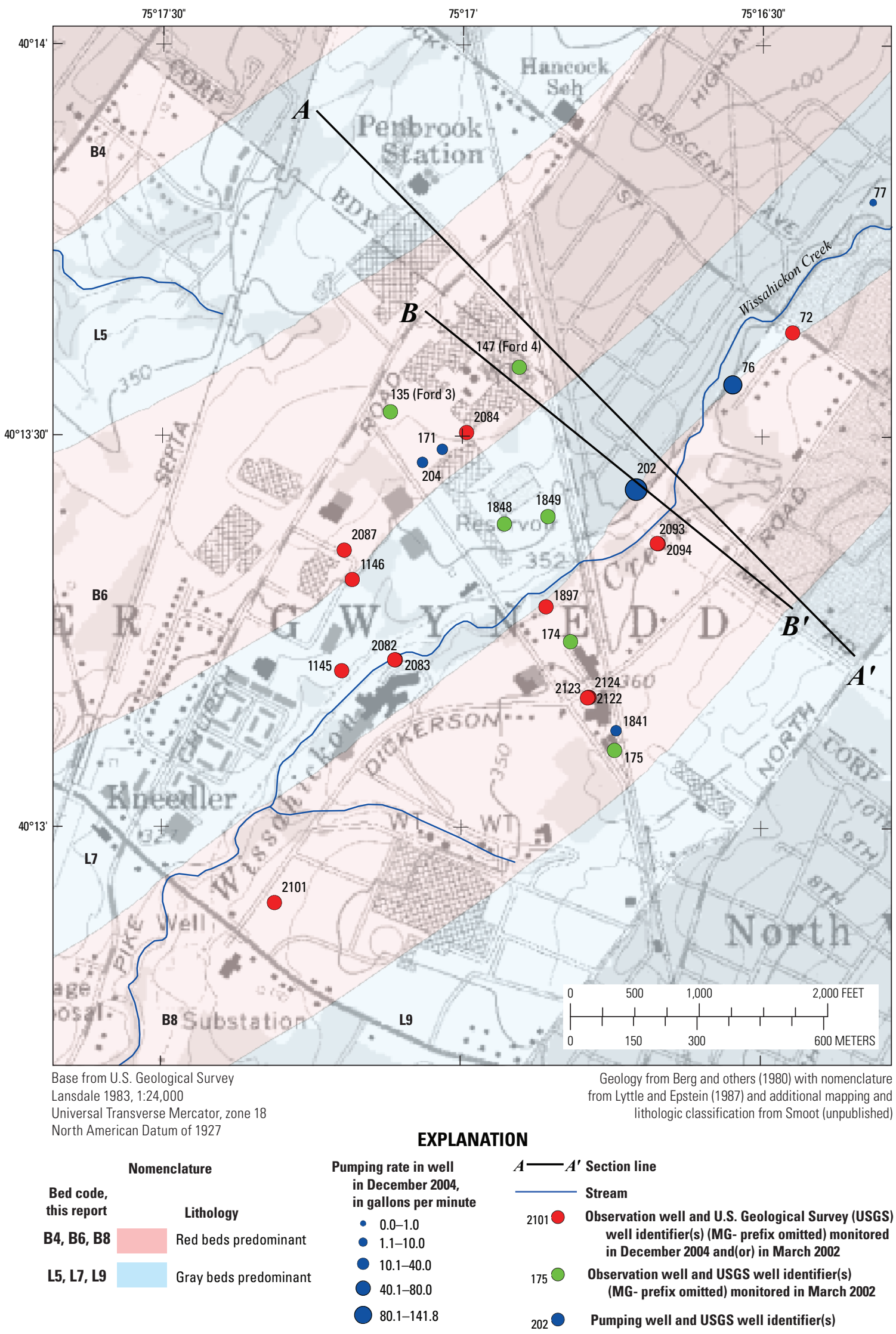

Figure 14. Location of pumped production and observation wells used for multiple well aquifer tests, and lines of section $A-A^{\prime}$ and $B-B^{\prime}$, at North Penn Area 7 Superfund site, Upper Gwynedd Township and vicinity, Montgomery County, Pennsylvania, 2002-2005. Cross sections for $A-A^{\prime}$ and $B-B^{\prime}$ lines shown in figure 15. 


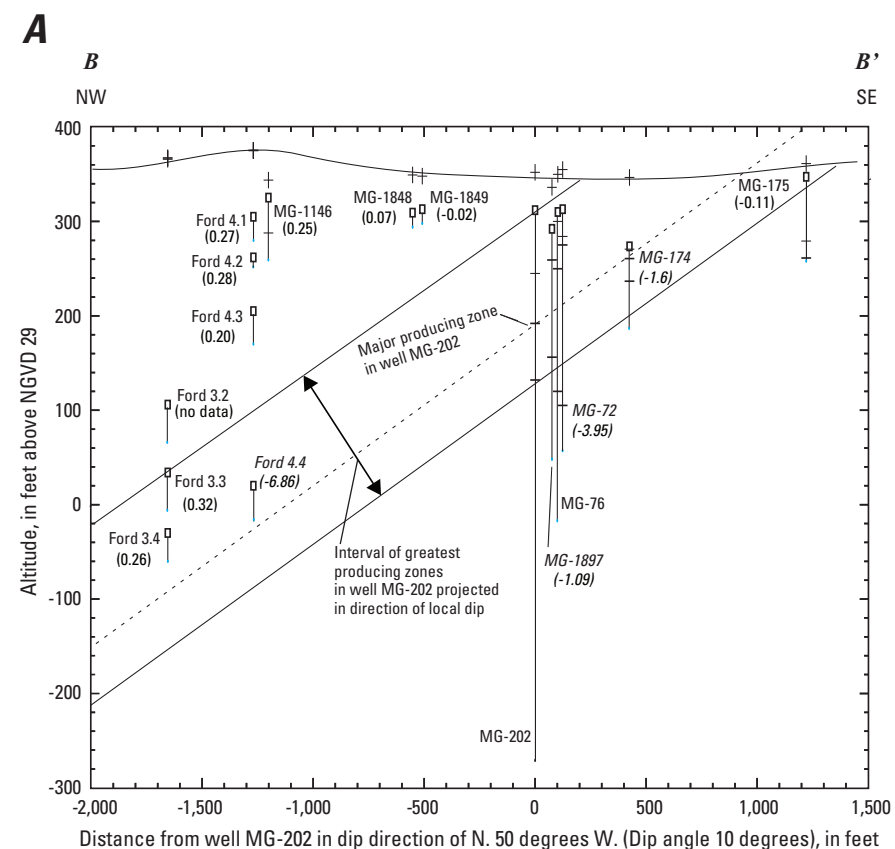

\author{
EXPLANATION \\ 口. Top of open interval \\ Bottom of open interval \\ Water-bearing zone \\ $+\quad$ Land-surface altitude at wellhead \\ MG-1848 Well identifer and change in water \\ (0.07) level, in feet, after 1,000 minutes \\ of pumping well MG-202, \\ restarted on March 5, 2002; \\ italized if showing relatively \\ large drawdown
}

B

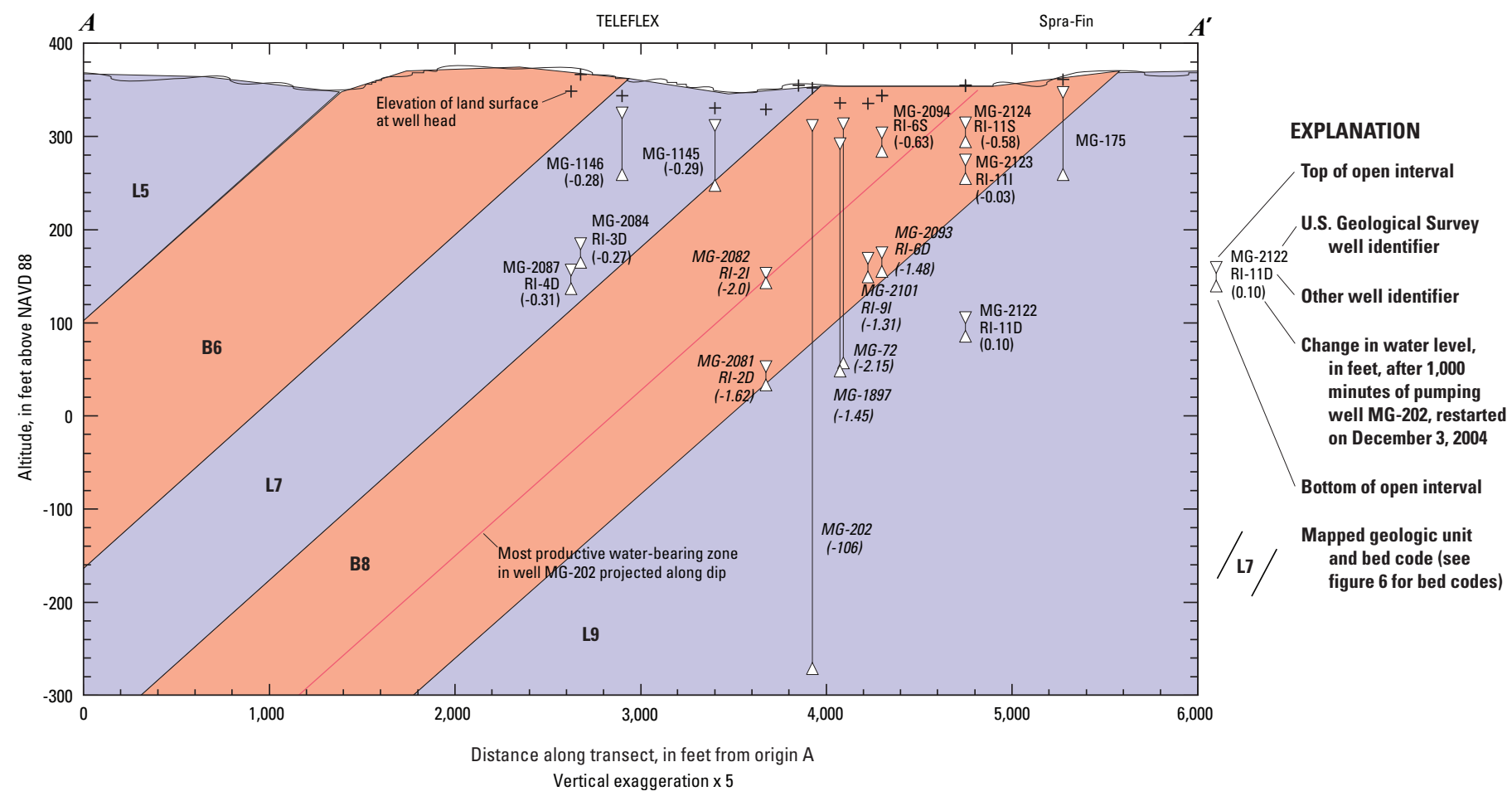

Figure 15. $A$, section $B-B^{\prime}$ with production well MG-202 (L-22) and 15 observation wells monitored during shutdown and after restart of pumping in well MG-202 in March 2002 and $B$, section $A-A^{\prime}$ with production well MG-202, 14 observation wells monitored during shutdown and restart of pumping in well MG-202 in December 2004, well MG-175 at the Spra-Fin property, and mapped geologic units at and near North Penn Area 7, Upper Gwynedd Township and vicinity, Montgomery County, Pennsylvania. Well open interval is depicted with measured change in water levels 1,000 minutes after restart of pumping in well MG-202 on March 5, 2002, and December 3, 2004. Changes in water levels in wells shown on figure are not corrected for changes in background water levels, which were +0.10 feet (rise) and -0.44 feet (decline), respectively, for the March 2002 and December 2004 tests in background well MG-68. (Figures modified from $A$, Senior and others (2005) and $B$, Senior and others (2008). Lines of sections are shown in figure 14. Mapped geologic units in 15A are shown in figure 6.) 


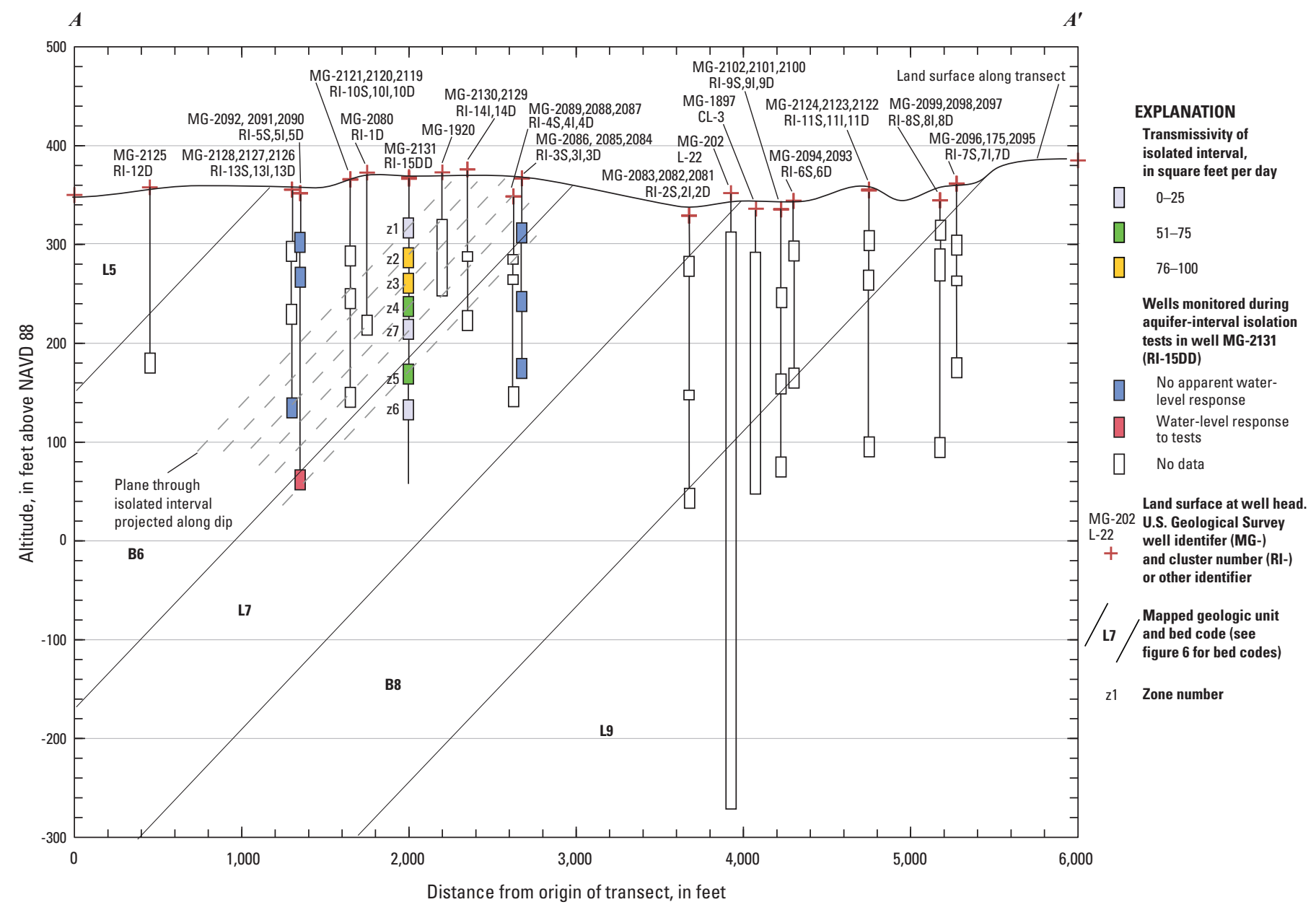

Figure 16. Water-level responses to pumping of isolated intervals in well MG-2131 (RI-15DD) in June 2005, North Penn Area 7 Superfund site, Upper Gwynedd Township and vicinity, Montgomery County, Pennsylvania. (Locations of wells are shown in figure 6, and measured water levels are shown in figure 17. Line of section is shown in figure 14.) 
(RI-15DD) (zone 5 in Senior and others, 2008), responds measurably to pumping (fig. 17). The water-level responses in MG-2090 (RI-5D) track water-level changes resulting from both pumping and packer inflation in any interval in MG-2131 (RI-15DD) that included fractures at 193 to $215 \mathrm{ft}$ below land surface. Thus, the two wells were connected through the fractures at 193 to $215 \mathrm{ft}$ below land surface while well MG-2131 (RI-15DD) was an open borehole during the packer testing and before reconstruction. Wells located nearby but not open updip or downdip from the 193 to $215 \mathrm{ft}$ interval and other tested intervals in well MG-2131 (RI-15DD) did not respond. Long open sections of boreholes can act as short circuits to connect fractures in layers of the aquifer that under natural conditions are separated.

The spatial distribution and magnitude of hydraulic connections of water-bearing fractures will vary at the local scale from site to site and are likely to be specific to each site at the local scale. Additional multi-well aquifer tests would be needed to establish extent of interconnection between intervals at the local scale to address remediation or migration of contamination at each source area.

\section{Groundwater Levels}

Water levels were measured by USGS in existing and new monitor wells in synoptic rounds in 2000, 2005, and 2006 to provide information on horizontal and vertical gradients and depth to water throughout North Penn Area 7. Data on the synoptic water levels, water levels measured by USGS in 1996, and water levels measured and reported by Merck \& Co. in 2000 and 2005 for about 40 observation wells on and near the Merck facility in West Point, Pa., were used in the calibration of the groundwater-flow model. Also, water levels in four wells were measured continuously by USGS for various long-term periods from 2000 through 2006 to provide information about groundwater conditions during the RI. Three of the four wells (MG-72, MG-1145, MG-1146) are within the boundary of the North Penn Area 7 (fig. 4) or within about $1,000 \mathrm{ft}$ of the boundary, and the fourth well (MG-68) is about $3,500 \mathrm{ft}$ to the northwest (figs. 3 and 4). Well MG-68 provided background water-level data because the well did not appear to be directly affected by pumping in the area after early 2000 when a nearby production well (MG-69, fig. 4) in Lansdale was shutdown.

Depths to static water levels in wells in North Penn Area 7 from December 2000 through September 2006 ranged from about 6 to $83 \mathrm{ft}$ below land surface, generally were least in shallow wells near streams or springs, and were greatest in wells affected by nearby pumping or on hilltops. Water levels fluctuated seasonally in response to changes in recharge and were lowest during dry periods in 2001 and 2002. Regionally, groundwater levels, as mapped in 2000 (Senior and Ruddy, 2004) and measured in the synoptic rounds from 2000 through 2005 , indicate a potentiometric surface similar to the topography, except in areas affected by relatively large amounts of pumping.
In the December 2000 synoptic round, water levels were measured by USGS in 56 existing non-pumping residential, production, and monitor wells; those water levels combined with water levels reported by Merck \& Co. in 40 observation wells on or near their West Point facility were used to estimate the altitude and configuration of the regional potentiometric surface at and near North Penn Area 7 (Senior and Ruddy, 2004). These existing mostly, open-hole wells range in depth from less than $50 \mathrm{ft}$ to more than $400 \mathrm{ft}$, although most wells (about 70 percent) range in depth from 50 to $200 \mathrm{ft}$. Wells for residential, industrial, and water supply typically are constructed as open holes (surface casing only) in competent bedrock aquifers and frequently have more than one water-bearing zone; therefore, measured water levels in these wells typically represent composite heads. Cones of depression are indicated in an area at and near the Merck facility where numerous wells pump a total of about 1 million gallons per day (Mgal/d). The regional potentiometric surface estimated from measured water levels appears relatively flat at North Penn Area 7 with water-level altitudes within the approximate site boundary (fig. 4) ranging from 301 to $323 \mathrm{ft}$ above NAVD 88 in 2000.

Comparison of water levels measured in the same wells in August 1996, December 2000, and June 2005 indicates that levels generally were 1 to $15 \mathrm{ft}$ higher in 1996 and 2005 than in 2000, except in some areas where water levels were locally affected by nearby pumping that appeared to vary over time. For example, differences in water levels between measurement periods were as large as $69 \mathrm{ft}$ at the Merck facility, probably because of different rates of nearby pumping at the time of measurement. Evaluation of water-level records for the nearest USGS observation wells completed in similar geologic units (BK-929 and BK-1020 in Bucks County, fig. 2) shows levels were close to long-term annual mean water levels in August 1996 but about 2 to $3 \mathrm{ft}$ lower than the long-term annual means in December 2000 (fig. 18). These long-term records indicate that regional water levels were below average for fallto-winter periods during 2000-02 and fall 2005 and generally above average from early 2003 to mid-2005 and 2006.

Several additional rounds of synoptic water-level measurements were made in new monitor and existing wells in the immediate vicinity of North Penn Area 7 from late fall 2004 through spring of 2006. Water levels in 76 wells were measured during December 2004, 82 wells during June 2005, 83 wells during September 2005, 49 wells during October 2005, and 90 wells during March 2006. Water levels measured in December 2004, June 2005, and March 2006 when compared to long-term data (wells BK-929 and BK-1020) were slightly higher than or close to long-term annual means. Water levels typically exhibit seasonal fluctuations and are lowest in the fall, but water levels measured in September and October 2005 were lower than long-term seasonal and long-term annual means. Although 2005 overall was a relatively normal year in terms of annual precipitation, precipitation was below normal from April to October, and water levels in wells declined by as much as $15 \mathrm{ft}$ during this relatively dry period. As part of the RI, groundwater samples were collected by CDM for the 

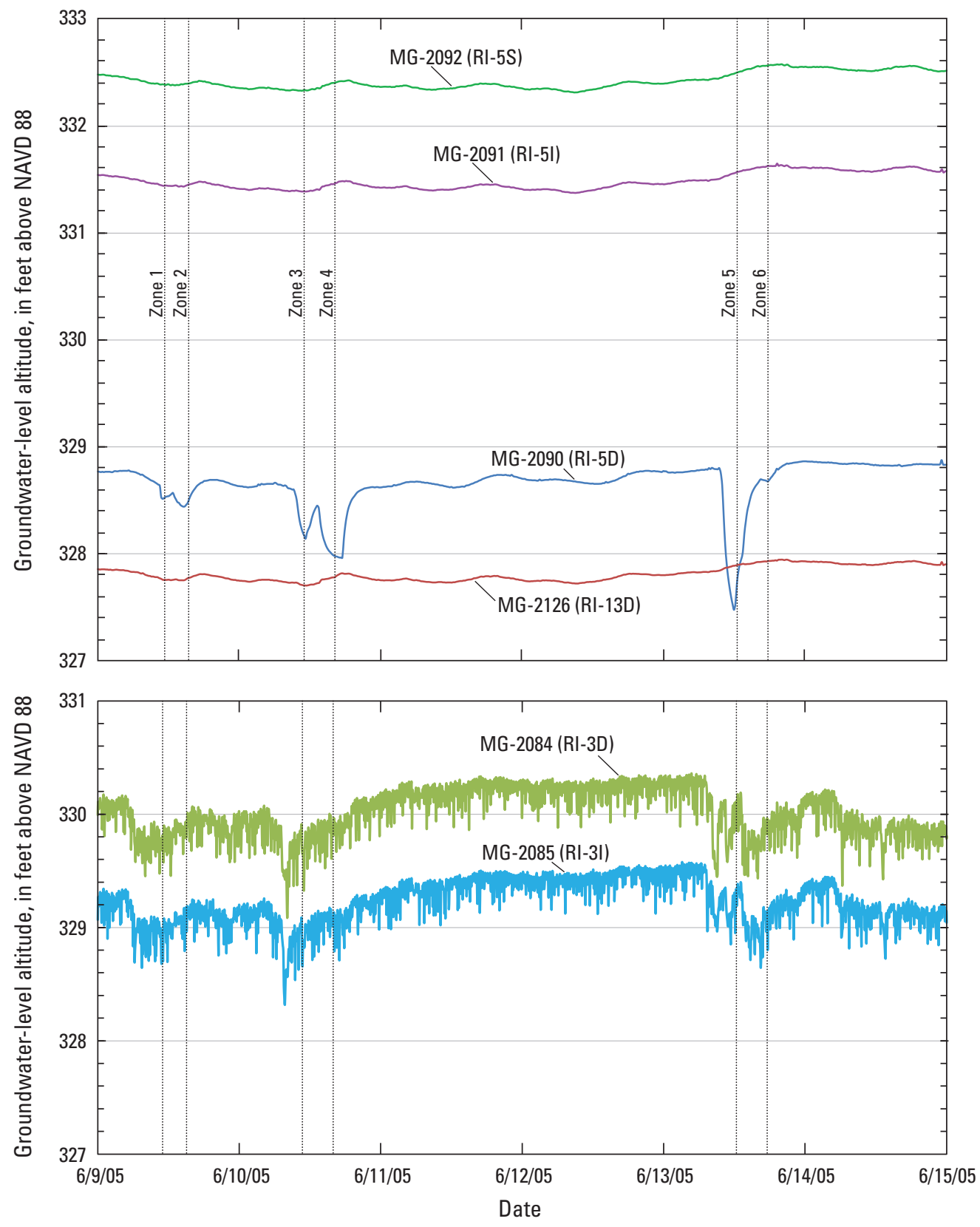

EXPLANATION

Time of tests of isolated zones in well MG-2134 (RI-15)

Figure 17. Water levels measured in $A$, wells MG-2085 (RI-3I) and MG-2084 (RI-3D) and $B$, MG-2092 (RI-5S), MG-2091 (RI-5I), MG-2090 (RI-5D), and MG-2126 (RI-13D) during the packer test of well RI-15DD (MG-2131), June 9-13, 2005, North Penn Area 7 Superfund site, Upper Gwynedd Township and vicinity, Montgomery County, Pennsylvania. (Open intervals of wells and isolated zones in well MG-2131 (RI-15DD) are shown in figure 16.) 


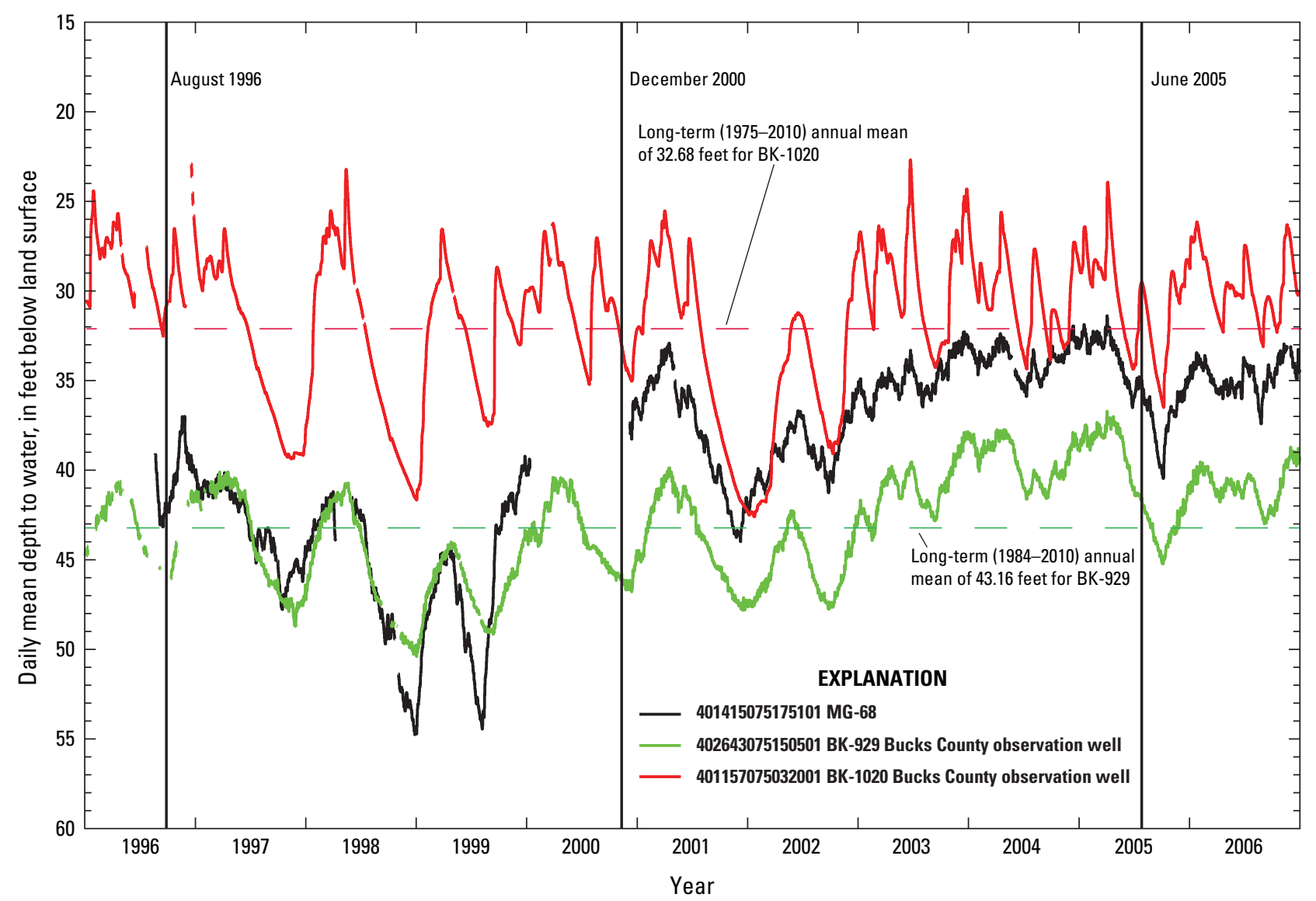

Figure 18. Water levels in long-term observation wells BK-929 and BK-1020 and in well MG-68, North Penn Area 7, Upper Gwynedd Township and vicinity, Montgomery County, Pennsylvania, 1996-2006. (Locations of wells BK-929 and BK-1020 are shown in figure 2 and location of well MG-68 in figure 3.)

USEPA in October 2005, a dry period when water levels were low, and in March 2006 when groundwater levels were on average about 6 to $7 \mathrm{ft}$ higher than in October 2005 .

Synoptic water-level measurements for the monitor well clusters showed the presence of vertical gradients, which were predominantly downward west of Wissahickon Creek and predominantly upward, except where affected by pumping, east of Wissahickon Creek (Senior and others, 2008; fig. 7). Although water levels in all wells fluctuated from one synoptic round of measurements to the next, vertical gradients were relatively similar for wells in clusters for all synoptic measurement rounds (table 78, p. 157-158 in Senior and others, 2008), except for wells in the RI-2 and RI-9 clusters (fig. 6). In these two clusters, vertical gradients increased substantially from December 2004 to periods in 2005 and 2006, and these changes appear to be independent of the drought in late summer and fall 2005. For the RI-2 cluster, water levels in the intermediate and deeper wells [MG-2082 (RI-2I) and MG-2081 (RI-2D)] declined much more (greater than 30 $\mathrm{ft})$ than levels in the shallow well [MG-2083 (RI-2S)]. For the RI-9 cluster, water levels in the shallow and intermediate wells [MG-2102 (RI-9S) and MG-2101 (RI-9I)] declined much more (greater than $30 \mathrm{ft}$ ) than levels in the deep well
[MG-2100 (RI-9D)]. The wells that had the largest declines have intervals open to the hydrogeologic unit most affected by pumping along the Wisshahickon Creek and at the Merck facility (see unit coded B8 in figures 4, 6, and 16).

\section{Streamflow Measurements and Groundwater/ Surface-Water Relations}

Streamflow under base-flow conditions was measured at selected locations (fig. 19) along Wissahickon Creek to evaluate groundwater/surface-water relations periodically from December 2000 to September 2005. The periodic streamflow measurements show that the stream lost water in the reach from station 01473808 at Wissahickon Avenue to 01473809 at Sumneytown Pike in 2001, 2002, most of 2003, summer 2005, and fall 2005 when groundwater levels were low and gained water in winter and spring 2004 and 2005 when groundwater levels were relatively high (fig. 20). The stream was dry (had no measureable base flow) at station 01473809 (fig. 19) in December 2000, summer and fall 2001, spring through summer 2002, and the summers of 2003, 2004, and 2005. A seepage study to investigate gains and losses from stream to 


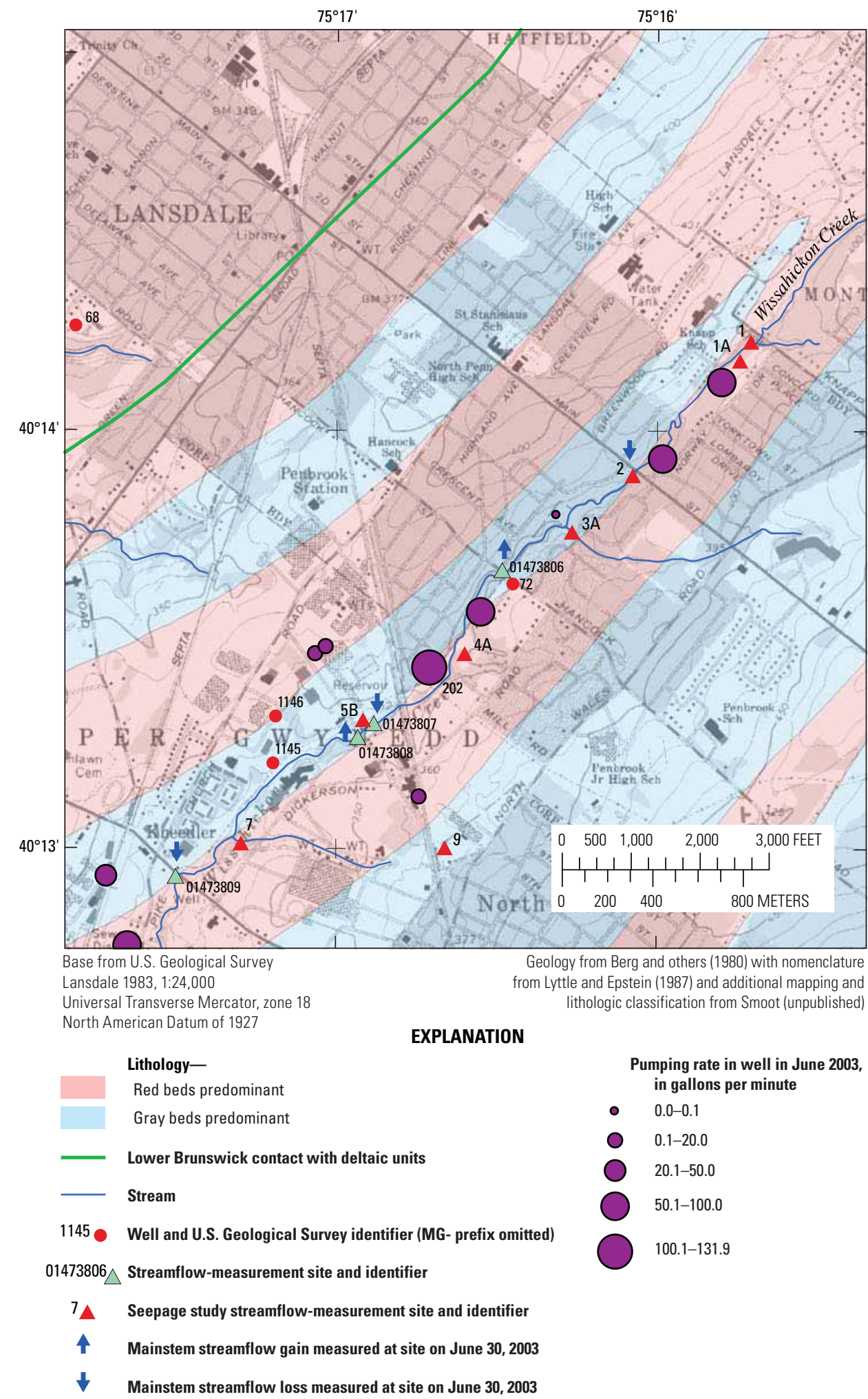

Figure 19. Location of pumped wells with pumping rates, observation wells, and streamflowmeasurement sites for the June 2003 seepage investigation on Wissahickon Creek and lithology at and near North Penn Area 7, Upper Gwynedd Township and vicinity, Montgomery County, Pennsylvania. 


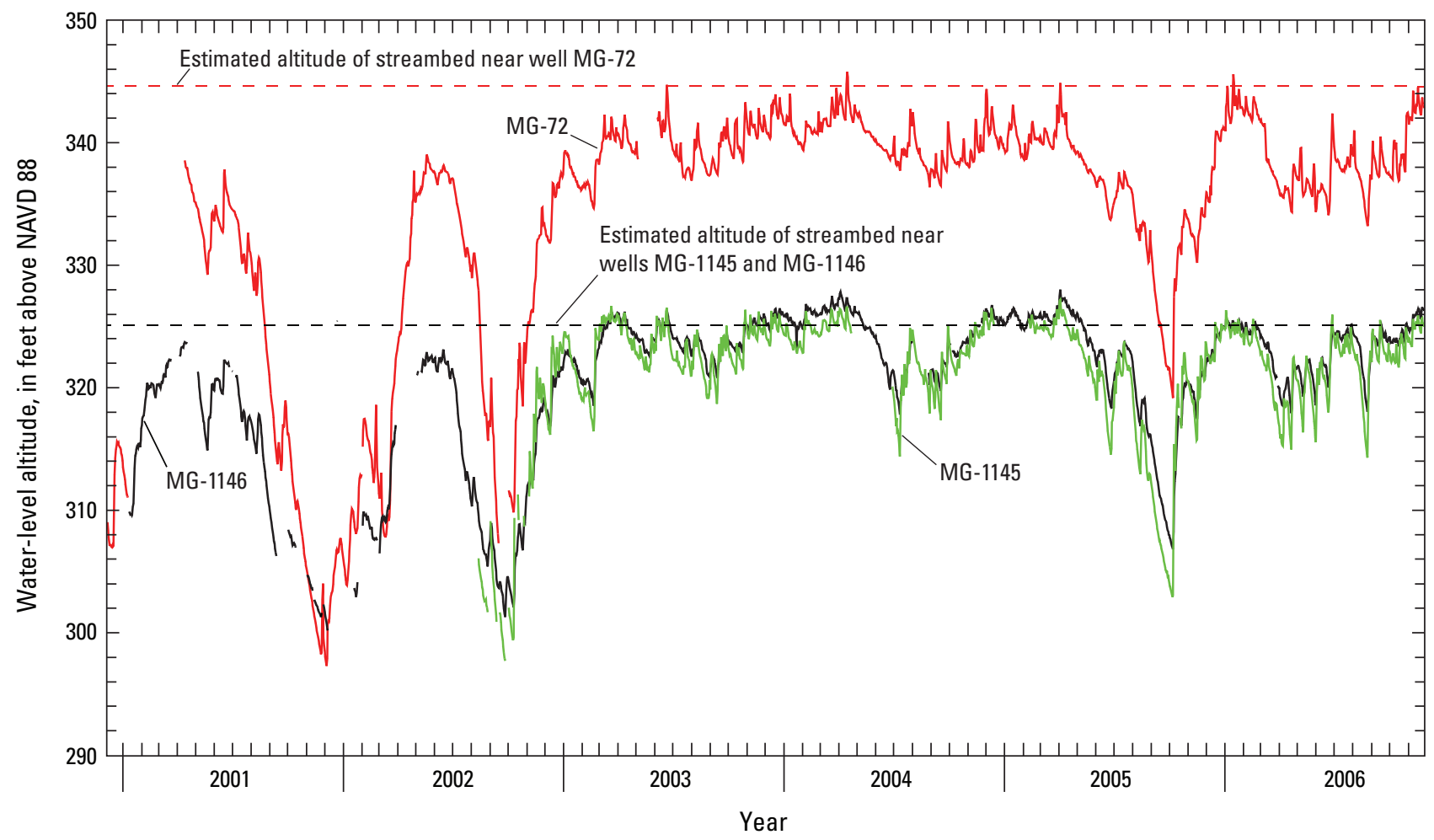

Figure 20. Measured groundwater levels (shown as altitudes) in wells MG-72, MG-1145, and MG-1146 and estimated altitudes of the streambed of Wissahickon Creek near the wells, at and near North Penn Area 7 Superfund site, Upper Gwynedd Township and vicinity, Montgomery County, Pennsylvania, December 2000-November 2006.

groundwater was conducted in late June 2003. Synoptic measurements of streamflow on June 30 and July 3, 2003 (Senior and others, 2005), indicate loss of streamflow in reaches with production wells near Wissahickon Creek (between sites 1 and 2 and between sites 01473806 and 01473807 in fig. 19). The June 2003 seepage study indicated a gain in streamflow between sites 2 and 01473806 , the latter being very near well MG-72. Streamflow measurements are described in detail in reports by Senior and others $(2005 ; 2008)$.

\section{Groundwater Quality at North Penn Area 7}

Data on groundwater quality at and near North Penn Area 7 were collected by USGS for isolated intervals of the aquifer during packer tests of existing wells and new deep monitor wells during 2001-05 (Senior and others, 2005; Senior and others, 2008); CDM sampled existing open-hole production, supply, and monitor wells and screened intervals of new monitor wells during 2001-06 (CDM Federal Programs Corporation 2011). Analyses for concentrations of volatile organic compounds (VOCs) and other contaminants in all groundwater samples were conducted by laboratories under contract to CDM and USEPA; complete results for these analyses are reported and interpreted in CDM (2011) and only briefly discussed in this report. Concentrations of VOCs in water samples collected from intervals isolated during packer tests were used to investigate the vertical extent of contamination in groundwater and to guide completion depths of nested wells in clusters. The spatial extent of VOCs and other contaminants at North Penn Area 7 were determined by CDM through sampling rounds in 2001, 2005, and spring 2006. Contaminant concentrations in groundwater generally were greatest for TCE and PCE at the site, but numerous other VOCs were detected, including 1,1,1-trichloroethane (TCA), 1,1-diochloroethene (DCE), 1,2-DCE, cis-1,2,-DCE, trans1,2-DCE, vinyl chloride (VC), carbon tetrachloride, and the chlorofluorocarbons CFC-11 and CFC-113.

\section{Groundwater Quality in Isolated Intervals}

Water samples were collected from the isolated intervals in the fractured-rock aquifer for use as screening values only because the samples potentially were affected by the condition of open boreholes. In open boreholes, water from producing fractures may travel in the borehole to exit in receiving fractures, and thus, water samples collected from the interval with receiving fractures may represent a mixture of water from that interval and other producing intervals in the open borehole. At 
North Penn Area 7, packer tests were done in boreholes that had been open for periods ranging from a few weeks for some recently drilled monitor wells to decades for some previously existing current and former production wells. Nevertheless, water chemistry of samples from the isolated intervals showed some distinct differences, which are supported by results of subsequent sampling by CDM in 2005 and 2006 of monitor well clusters, that provide evidence for a conceptual model of discrete flow paths through the layered aquifer.

Concentrations of TCE and some other VOCs tended to be, but were not always, greatest in the samples from shallow isolated intervals of wells at known contaminant source areas. Maximum concentrations of frequently detected VOCs in samples from isolated intervals were 640 micrograms per liter $(\mu \mathrm{g} / \mathrm{L})$ for TCE, $37 \mu \mathrm{g} / \mathrm{L}$ for PCE, $680 \mu \mathrm{g} / \mathrm{L}$ for cis-1,2,-DCE, $59 \mu \mathrm{gL}$ for $1,1,1-\mathrm{TCA}, 33 \mu \mathrm{g} / \mathrm{L}$ for $1,1-\mathrm{DCE}, 55 \mu \mathrm{g} / \mathrm{L}$ for CFC-11, and $71 \mu \mathrm{g} / \mathrm{L}$ for CFC-113. Maximum concentrations of some infrequently detected VOCs were $14 \mu \mathrm{g} / \mathrm{L}$ for vinyl chloride (VC) and $33 \mu \mathrm{g} / \mathrm{L}$ for carbon tetrachloride.

In addition to collection of water samples from isolated zones for VOC analysis, field measurements were made by USGS of $\mathrm{pH}$, temperature, specific conductance, dissolved oxygen concentration, acid neutralizing capacity (ANC) which often is similar or equivalent to alkalinity, nitrate, sulfate, sulfide, total iron, and ferrous iron in unfiltered samples by methods described in Senior and others $(2005 ; 2008)$. Summary statistics describing these measurements are listed in table 2, and graphs showing the distribution of selected waterquality characteristics of, and constituents in, water from isolated zones in each well are presented in figure 21. Generally, water samples had near neutral to slightly alkaline $\mathrm{pH}$; low to moderate concentrations of dissolved oxygen, nitrate, and sulfate; mostly low concentrations of total and ferrous iron; and moderate to high specific conductance (table 2). Comparison of water quality between wells indicates some general differences. Specific conductance is much higher [greater than 700 and up to 2,700 microsiemens per centimeter $(\mu \mathrm{S} / \mathrm{cm})]$ in water samples from isolated intervals in wells MG-2125, MG-2126, and MG-2090 (open boreholes later reconstructed as RI-12D, RI-13D, and RI-5D, respectively), in the western part of the study area than elsewhere. Alkalinity (as estimated by ANC) is also elevated ( 250 to $350 \mathrm{mg} / \mathrm{L}$ as $\mathrm{CaCO}_{3}$ ) in one of these wells [MG-2125 (later reconstructed as RI-12D)]. Sulfate concentrations in water samples from isolated intervals differ more among wells than among zones in an individual well.

\section{Groundwater Quality in Existing and New Monitor Wells}

Groundwater samples were collected by CDM from existing and new monitor wells during three rounds of sampling during 2001-06 as part of the RI to assess the extent of groundwater contamination at North Penn Area 7. Only existing wells were sampled during the first round in 2001-02, and both existing and new monitor wells were sampled during the second and third rounds in fall 2005 and spring 2006. The first round of groundwater samples was analyzed for VOCs, semivolatile organic compounds, pesticides, and selected major ions and metals. The second and third rounds of groundwater samples were analyzed for VOCS, selected major ions and metals, and a few additional inorganic constituents suggested by USGS, including chloride, sulfate, and silica in the second round samples and chloride, bromide, and boron in the third round samples.

Table 2. Summary statistics of physical and chemical characteristics measured in the field of unfiltered water samples collected from isolated zones in 15 deep monitor wells, North Penn Area 7 Superfund site, Upper Gwynedd Township and vicinity, Montgomery County, Pennsylvania, March 2004 through August 2005.

$\left[{ }^{\circ} \mathrm{C}\right.$, degrees Celsius; $\mathrm{mg} / \mathrm{L}$, milligrams per liter; $\mu \mathrm{S} / \mathrm{cm}$, microsiemens per centimeter at $25^{\circ} \mathrm{C}$; $\mathrm{ANC}$, acid neutralizing capacity; $\mathrm{mg} / \mathrm{L}$ as $\mathrm{CaCO}$, milligrams per liter as calcium carbonate; $\mathrm{mg} / \mathrm{L}$ as $\mathrm{N}$, milligrams per liter as nitrogen; $<$, less than]

\begin{tabular}{llcccccc}
\hline \multicolumn{1}{c}{ Characteristic } & \multicolumn{1}{c}{ Units } & $\begin{array}{c}\text { Number of } \\
\text { zones }\end{array}$ & Minimum & 10th percentile & Median & 90th percentile & Maximum \\
\hline $\mathrm{pH}$ & $\mathrm{pH}$ units & 106 & 6.34 & 7.03 & 7.49 & 7.83 & 8.09 \\
Temperature & ${ }^{\circ} \mathrm{C}$ & 105 & 11.7 & 13.1 & 14.5 & 17.6 & 19.1 \\
Dissolved oxygen & $\mathrm{mg} / \mathrm{L}$ & 106 & 0.10 & 0.16 & 1.40 & 4.33 & 9.00 \\
Specific conductance & $\mu \mathrm{S} / \mathrm{cm}$ & 105 & 362 & 390 & 578 & 1,026 & 2,742 \\
ANC (alkalinity) & $\mathrm{mg} / \mathrm{L}$ as $\mathrm{CaCO}_{3}$ & 106 & 25 & 133 & 159 & 201 & 354 \\
Sulfide & $\mathrm{mg} / \mathrm{L}$ & 102 & $<0.001$ & $<0.001$ & 0.003 & 0.016 & 0.070 \\
Ferrous iron $\left(\mathrm{Fe}^{2+}\right)$ & $\mathrm{mg} / \mathrm{L}$ & 103 & $<0.01$ & $<0.01$ & 0.03 & 0.12 & 1.47 \\
Iron, total & $\mathrm{mg} / \mathrm{L}$ & 103 & $<0.01$ & 0.07 & 0.17 & 0.43 & 2.02 \\
Sulfate & $\mathrm{mg} / \mathrm{L}$ & 103 & 9 & 18 & 30 & 42 & 59 \\
Nitrate & $\mathrm{mg} / \mathrm{L}$ as N & 103 & $<0.1$ & 0.1 & 0.8 & 1.5 & 3.1 \\
\hline
\end{tabular}



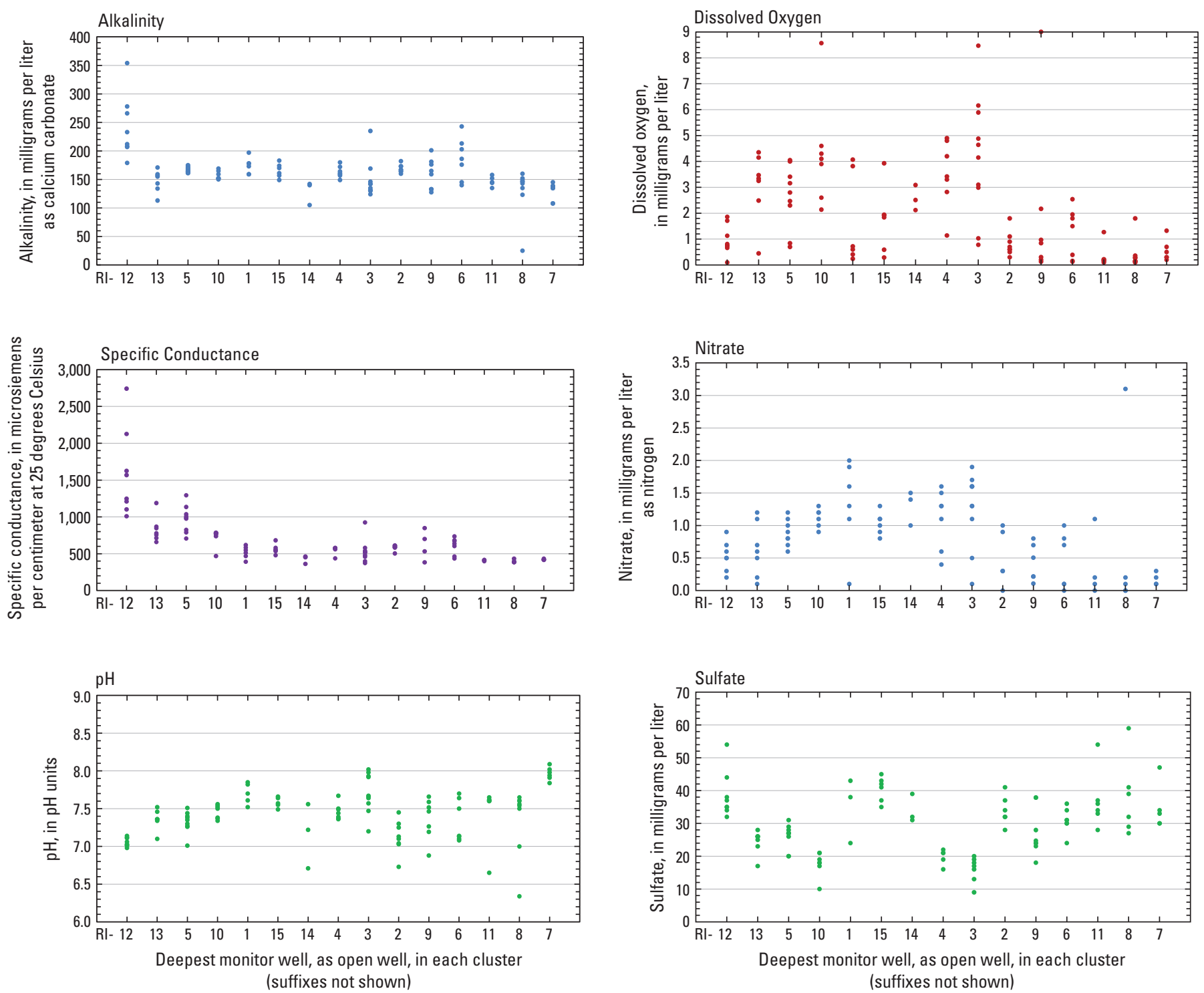

Figure 21. Specific conductance, acid neutralizing capacity as estimate of alkalinity, $\mathrm{pH}$, and concentrations of dissolved oxygen, nitrate, and sulfate measured in the field in water samples from isolated zones in 15 deep monitor wells, North Penn Area 7 Superfund site, Upper Gwynedd Township and vicinity, Montgomery County, Pennsylvania, March 2004 through August 2005. Results are plotted in order of wells projected onto line parallel to dip. 


\section{Volatile Organic Compounds and Metals}

The main contaminants identified in groundwater from the three rounds of sampling are VOCs, of which TCE was the VOC most frequently detected and measured at the highest concentrations [up to $650 \mu \mathrm{g} / \mathrm{L}$ in monitor well RI-11S (MG-2124)] (CDM Federal Programs Corporation, 2011). Other VOCs detected include, but are not limited to, PCE, cis-1,2-DCE, 1,1,1-TCA, 1,1-DCE, VC, CFC-11, and CFC113. The highest VOC concentration measured from 2001 to 2006 was $1,700 \mu \mathrm{g} / \mathrm{L}$ for cis-1,2-DCE in one sample from well MG-1841 (SF-1) in 2001, although concentrations of cis-1,2DCE were less than $330 \mu \mathrm{g} / \mathrm{L}$ for all other samples (CDM Federal Programs Corporation, 2011). Arsenic, chromium, iron, lead, manganese, and mercury are the metals most frequently measured in concentrations greater than health-screening levels, as reported by CDM (2011). The occurrence and distribution of VOCs and metals are described and discussed in detail in the RI report prepared by CDM (2011).

\section{Selected Inorganic Constituents}

As part of the assessment of the spatial distribution of contaminants in groundwater in wells at and near North Penn Area 7, water samples collected by CDM in fall 2005 (second round) and spring 2006 (third round) were also analyzed for one or more selected inorganic constituents, including chloride, boron, bromide, silica, and sulfate. These inorganic constituents were thought to be potentially useful in understanding the groundwater-flow system and (or) determining potential contaminant sources and pathways. In addition, chloride and sulfate were analyzed to identify the ions causing the high specific conductance, determined through geophysical logging of some wells, as concentrations of these anions commonly are elevated in water that has high specific conductance. Acid neutralizing capacity (ANC), a field measure that is approximately equivalent to alkalinity (and of the bicarbonate ion), was determined by USGS during packer tests during 2002-04 and, in general, was not found to differ much between wells, ranging mostly from about 130 to $200 \mathrm{mg} / \mathrm{L}$ as $\mathrm{CaCO}_{3}$ with and without high fluid conductance identified during logging. The exceptions are samples from well MG-2125 (RI-12), which had the highest ANC (alkalinity) values of up to $354 \mathrm{mg} / \mathrm{L}$ as $\mathrm{CaCO}_{3}$ (fig. 14). In fall 2005, samples from all reconstructed monitor wells were analyzed for chloride, silica, and sulfate. In spring 2006, samples were analyzed for chloride, boron, and bromide.

Evaluation of chloride, nitrate, and sulfate concentrations and other data not collected during the RI, such as hydrogen or ethane concentrations, may be helpful in understanding the extent of possible PCE or TCE degradation at North Penn Area 7. A detailed assessment of the potential for degradation of PCE and TCE is beyond the scope of this report.

\section{Chloride}

Chloride is a naturally occurring constituent in the environment but also can be artificially introduced by various human activities. Once dissolved, chloride is a relatively conservative anion (not degraded, readily adsorbed, or precipitated) and may be used as a tracer in groundwater and surface-water flow. At North Penn Area 7, chloride concentrations greater than natural background levels could originate from several sources. In urban and suburban areas, a common source of chloride released on the land surface is road salt used for de-icing. Sodium chloride is the most common component of road salt, but other compounds, such as calcium chloride, are used. Chloride may also be released into groundwater as part of degradation processes of halogenated organic compounds, such as TCE.

Most chloride concentrations measured during fall 2005 and spring 2006 rounds of sampling by CDM at North Penn Area 7 did not differ much between sampling rounds and were within the range of 10 to $50 \mathrm{mg} / \mathrm{L}$ in about half of the samples, slightly to moderately elevated above natural background concentrations in southeastern Pennsylvania, estimated to be about $10 \mathrm{mg} / \mathrm{L}$ or less (Senior and other, 1997). Across the site at North Penn Area 7, chloride concentrations generally decreased with depth of water samples from monitor well clusters, indicating near-surface or surface sources of chloride (figs. 22, 23).

Samples from some monitor wells had substantially elevated chloride concentrations - greater than $100 \mathrm{mg} / \mathrm{L}$ to as high as $350 \mathrm{mg} / \mathrm{L}$. The highest chloride concentrations were in samples from shallow- and intermediate-depth monitor wells [MG-2092 (RI-5S), MG-2091 (RI-5I), MG-2128 (RI-13S), MG-2127 (RI-13I), MG-2121 (RI-10S), MG-2120 (RI-10I)] west of Church Road on the former Zenith and adjacentproperties, one shallow monitor well [MG-2086 (RI-3S)] on the former Ford property (figs. 22 and 23), and two shallow open-hole wells (MG-1844, MG-1845) at an industrial facility along North Wales Road (fig. 22). Sources of the substantially elevated chloride concentrations in groundwater are unknown, but road salt is a likely source for wells near North Wales Road and a possible contributing source for the wells west of Church Road, as these latter wells are near parking lots. However, water from other wells near roads and parking lots elsewhere at North Penn Area 7 typically do not have such high chloride concentrations, suggesting an additional source of chloride for the wells west of Church Road.

Sulfate

Sulfate concentrations were used to identify the source of elevated specific conductance and to assess the potential for, and extent of, anaerobic degradation of chlorinated solvents, such as TCE, in groundwater. Sulfate concentrations in samples collected from reconstructed monitor wells in North Penn Area 7 ranged from 10 to $68.6 \mathrm{mg} / \mathrm{L}$, were between 20 and $35 \mathrm{mg} / \mathrm{L}$ in samples from most wells, generally were not elevated above background levels estimated from regional studies (Sloto and Schreffler, 1994; Durlin and Schaffstall, 2000, p. 599), and showed no strong pattern in relation to depth or spatial distribution. The reported sulfate concentrations in the samples collected in fall 2005 confirmed 


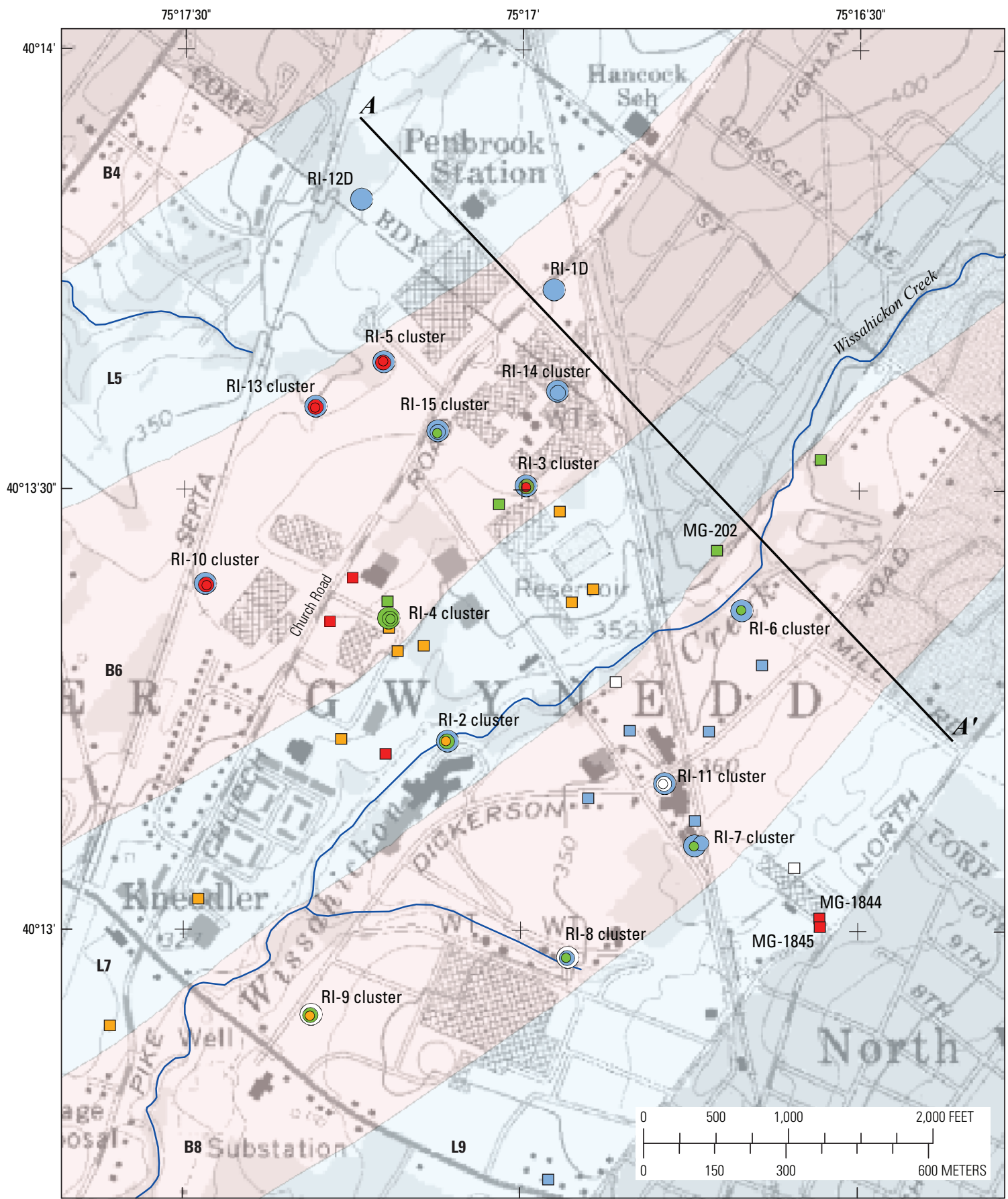

Base from U.S. Geological Survey

Lansdale 1983, 1:24,000

Universal Transverse Mercator, zone 18

North American Datum of 1927

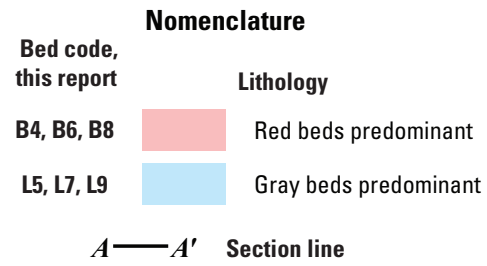

\section{EXPLANATION}

$\begin{array}{lll}\begin{array}{l}\text { Type of well-Label is } \\ \text { well (MG-) or cluster (RI-) } \\ \text { identifier }\end{array} & \begin{array}{c}\text { Chloride concentrations in } \\ \text { groundwater samples (2006), } \\ \text { in micrograms per liter }\end{array} \\ \text { Shallow monitor } & 0 & 11.7-25.0 \\ \text { Intermediate monitor } & 0 & 25.1-50.0 \\ \text { Deep monitor } & 0 & 50.1-75.0 \\ \square \quad \text { Open-hole existing well } & 0 & 75.1-100.0 \\ & 0 & 100.1-304.0\end{array}$

Figure 22. Chloride concentrations in samples collected in spring 2006 from monitor well clusters and open-hole wells and line of section $A-A^{\prime}$, North Penn Area 7 Superfund site, Upper Gwynedd Township and vicinity, Montgomery County, Pennsylvania. (Section $A-A^{\prime}$ is shown in figure 23.) 


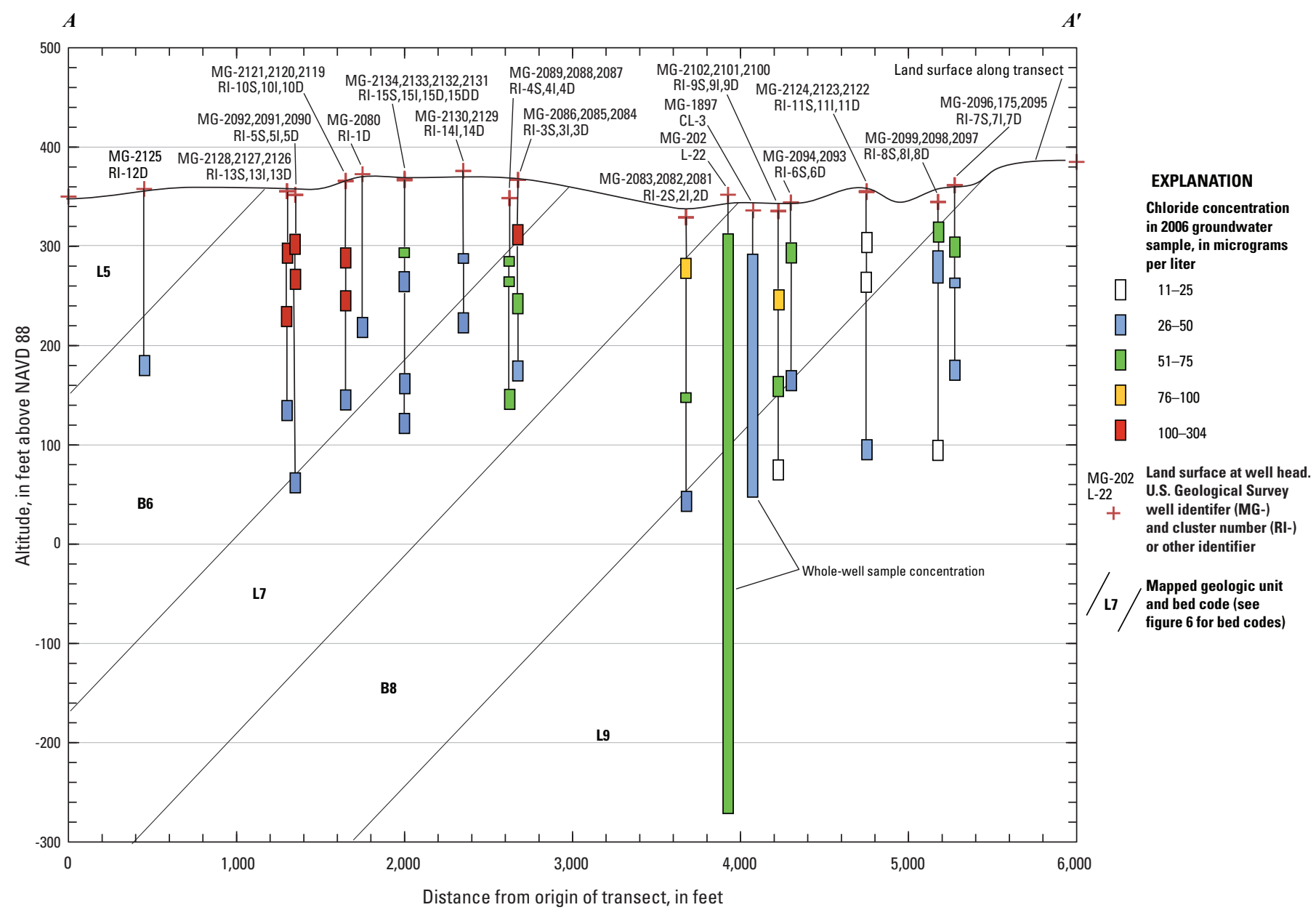

Figure 23. Locations of monitor wells projected onto a line parallel to dip and chloride concentrations in samples collected from the monitor wells in spring 2006, North Penn Area 7 Superfund site, Upper Gwynedd Township and vicinity, Montgomery County, Pennsylvania. (See figure 22 for location of line of section.) 
concentrations previously estimated using a field spectrophotometer for analysis of samples from packer tests (Senior and others, 2008). The moderate sulfate concentrations and alkalinity indicate chloride is the main anion associated with high specific conductance measured in some wells at North Penn Area 7.

During anaerobic degradation under sulfate-reducing conditions of VOCs, sulfate concentrations may decrease and sulfide concentrations concurrently increase (Chapelle and Bradley, 1998), although sulfide may precipitate out of solution if iron is present (Kennedy and others, 1998). Sulfide concentrations measured in samples collected during packer tests using a field spectrophotometer were less than $0.06 \mathrm{mg} / \mathrm{L}$ (Senior and others, 2005; 2008); these low concentrations indicate some, but relatively little, reduction of sulfate and associated concurrent degradation of chlorinated solvents. At concentrations greater than $20 \mathrm{mg} / \mathrm{L}$, sulfate may compete with the reductive pathway for degradation of VOCs (Wiedemeier and others, 1998). Heimann and others (2005) report that sulfate concentrations greater than 2.5 millimolar (mM) (or $240 \mathrm{mg} / \mathrm{L}$ ) may limit microbial dechlorination of TCE and other chlorinated solvents. At North Penn Area 7, sulfate concentrations in groundwater were frequently in the range of 20 to $35 \mathrm{mg} / \mathrm{L}$ and as high as to $69 \mathrm{mg} / \mathrm{L}$ and, therefore, could be, but not necessarily are, limiting for anaerobic degradation of VOCs.

Many zones tested during packer tests at North Penn Area 7 (Senior and others, 2005; 2008) had low concentrations (less than $1 \mathrm{mg} / \mathrm{L}$ ) of dissolved oxygen and nitrate, and a few had elevated concentrations ( 1 to $2 \mathrm{mg} / \mathrm{L}$ ) of ferrous iron, consistent with reducing conditions that may be associated with degradation of chlorinated ethenes. The detection of PCE and TCE degradation products in groundwater, such as cis-1,2-DCE across the site and VC detected at Spra-Fin property, indicate that degradation occurs in the areas sampled but that sulfate reduction does not appear to be a main part of the process.

\section{Silica}

Silica may accumulate in groundwater as a product of mineral weathering, and concentrations have sometimes been found to correlate with residence time (Burns and others, 2003). Silica concentrations in samples from the monitor well clusters ranged from about 14.7 to $26.4 \mathrm{mg} / \mathrm{L}$ and tended to be higher in samples from the shallow or intermediate well than from the deep well in each cluster (figs. 24, 25). This finding indicates the following possible explanation. Shallow groundwater follows different flow paths than deeper groundwater, and water reacts more extensively with minerals because of greater surface area and more reactive geochemical environment in the shallow weathered zone and less extensively with minerals in fractures at depth. Also, groundwater may travel more slowly in the shallow weathered zone with relatively higher porosity than in fracture networks at depth. Some water at depth may be recharged relatively rapidly through preferential paths, reducing transit time through the shallow weathered zone; however, variability in groundwater chemistry (such as $\mathrm{pH}$ ) and mineral composition of aquifer materials will affect, and may alternatively explain, the distribution of dissolved silica in groundwater. From limited analyses of the chemical data, it is unclear whether or not silica concentrations reflect residence time in the hydrogeologic setting at North Penn Area 7.

Boron

Boron is a naturally occurring trace element that occurs in elevated concentrations (up to about $5,000 \mu \mathrm{g} / \mathrm{L}$ ) in mineralized areas of the Newark Basin (Senior and Sloto, 2006), but natural background concentrations typically are less than $40 \mu \mathrm{g} / \mathrm{L}$ in non-mineralized areas. Elevated boron concentrations in groundwater of as much as $24,700 \mu \mathrm{g} / \mathrm{L}$ were found to be associated with the Salford Quarry site, located about $10 \mathrm{mi}$ northwest of North Penn Area 7 and used by several industries including the former American Olean Tile of Lansdale for waste disposal (U.S. Environmental Protection Agency, 2010). Boron was selected for analysis as a possible indicator of industrial waste after broken waste tile from American Olean was observed in disturbed fill on the former Clearline property (between wells MG-174 and MG-1897, fig. 6) in North Penn Area 7.

Boron concentrations in water samples from wells at North Penn Area 7 ranged from less than 20 to $220 \mu \mathrm{g} / \mathrm{L}$ and were highest in the RI- 6 well cluster and wells along the strike from that cluster (figs. 26, 27). Boron concentrations were greater than or about equal to $100 \mu \mathrm{g} / \mathrm{L}$ in water from five wells, four of which are along the strike in the same geologic unit, denoted as B8, [181 $\mu \mathrm{g} / \mathrm{L}$ in well MG-2094 (RI-6S); $220 \mu \mathrm{g} / \mathrm{L}$ in well MG-2093 (RI-6D); $122 \mu \mathrm{g} / \mathrm{L}$ in well MG-2081 (RI-2D); and $94 \mu \mathrm{g} / \mathrm{L}$ in well MG-1541 (N5)] and one of which is in a separate unit, denoted as L7, [110 $\mu \mathrm{g} / \mathrm{L}$ in well MG-2090 (RI-5D)] (figs. 26, 27). The highest boron concentrations were near, but not at, wells on the former Clearline property (MG-174 and MG-1897), and thus, the data do not clearly support an association of elevated boron in groundwater with the occurrence of waste tile in disturbed soil. The source of slightly elevated boron concentrations in groundwater (greater than the estimated background of about $40 \mu \mathrm{g} / \mathrm{L}$ ) is unknown. The spatial distribution of the slightly elevated boron concentrations may be related to a natural occurrence in the geologic formation that follows geologic structure (bedding orientation) or may follow groundwater transport partly controlled by geologic structure from a natural or anthropogenic source (such as one related to waste-disposal activities).

\section{Bromide}

Bromide is a relatively soluble halide anion, like chloride. Chloride/bromide molar or mass ratios have been used to distinguish sources of salinity (Edmunds, 1996; Davis and others, 1998; Vengosh and Pankratov, 1998; Davis and others 2004) and were selected by USGS for analysis to possibly 


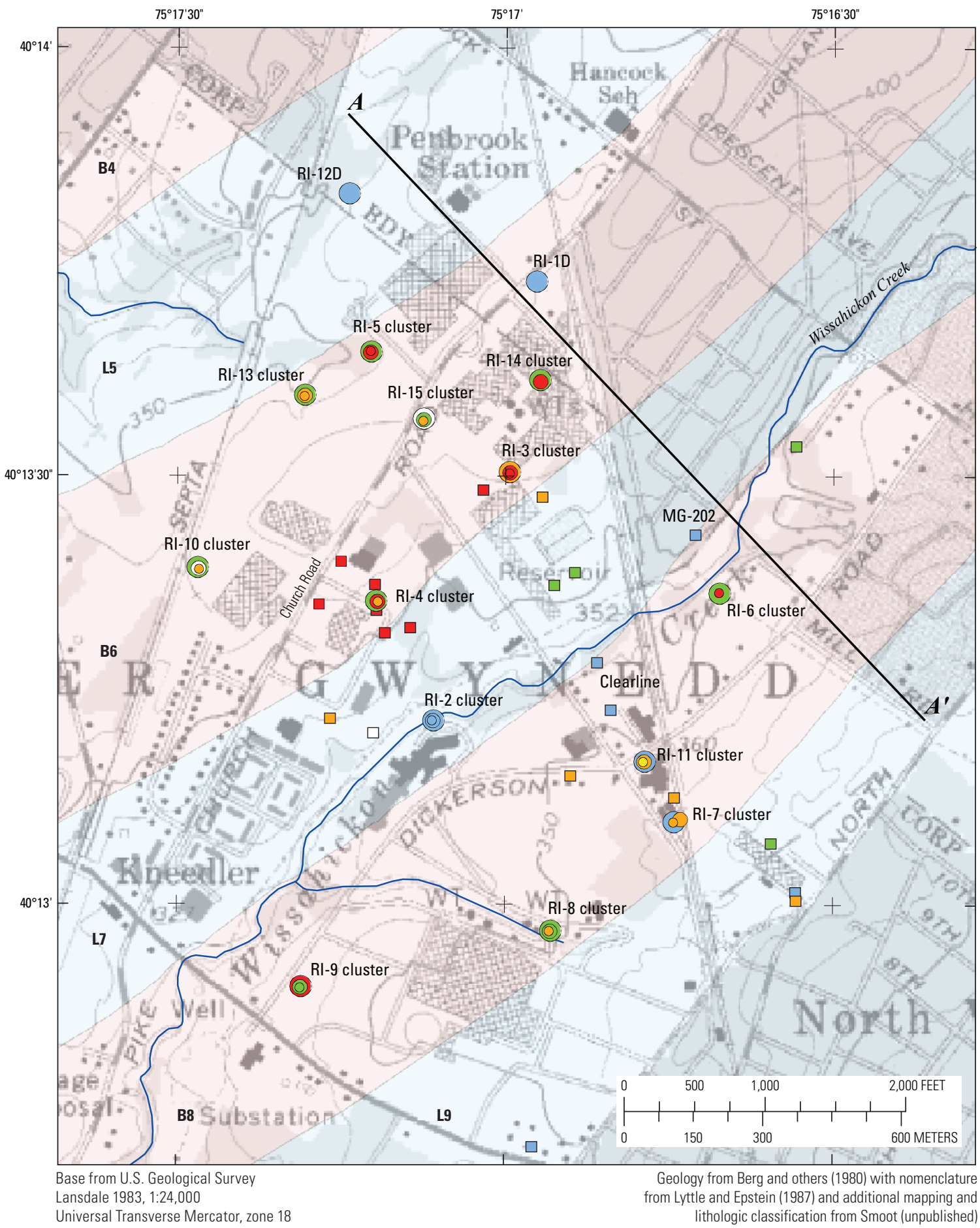

Universal Transverse Mercator, zone 18

North American Datum of 1927

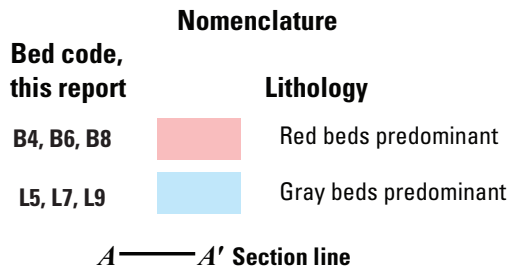

\section{EXPLANATION}

Type of well-Label is
well (MG-) or cluster (RI-)
identifier
Shallow monitor
Intermediate monitor
Deep monitor
Open-hole existing well

\begin{tabular}{|c|c|}
\hline & $\begin{array}{l}\text { ica concentrations in } \\
\text { groundwater samples (2005), } \\
\text { in micrograms per liter }\end{array}$ \\
\hline $\mathrm{O}$ & $14.7-16.0$ \\
\hline o & $16.1-18.0$ \\
\hline 0 & $18.1-20.0$ \\
\hline & $20.1-22.0$ \\
\hline & $22.1-25.2$ \\
\hline
\end{tabular}

Figure 24. Silica concentrations in samples collected in fall 2005 from monitor well clusters and open-hole wells, and line of section $A-A^{\prime}$, North Penn Area 7 Superfund site, Upper Gwynedd Township and vicinity, Montgomery County, Pennsylvania. (Section $A-A^{\prime}$ is shown in figure 25.) 


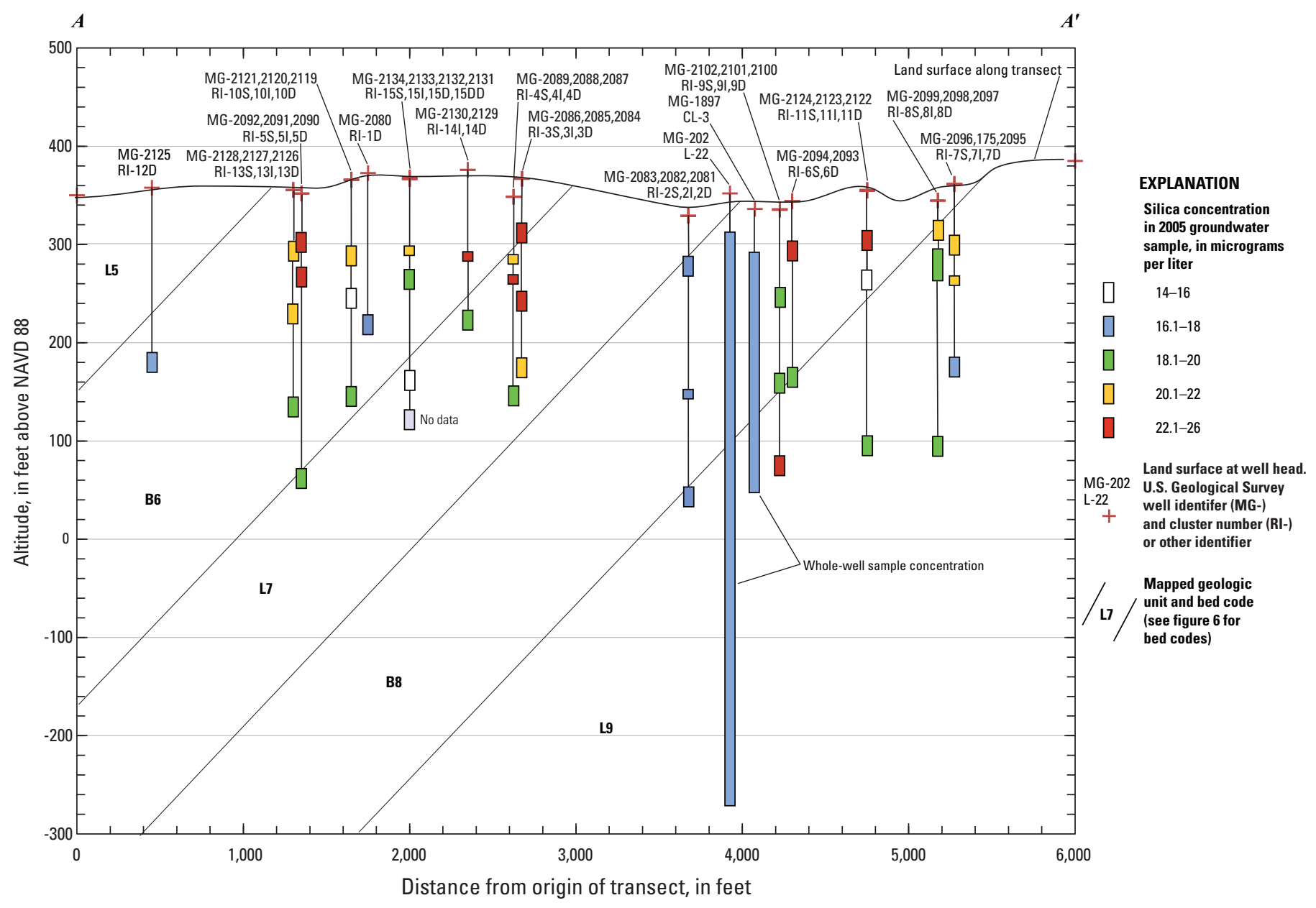

Figure 25. Locations of monitor wells projected onto a line parallel to dip and silica concentrations in samples collected from the monitor wells in fall 2005, North Penn Area 7 Superfund site, Upper Gwynedd Township and vicinity, Montgomery County, Pennsylvania. (See figure 24 for line of section $A-A^{\prime}$.) 


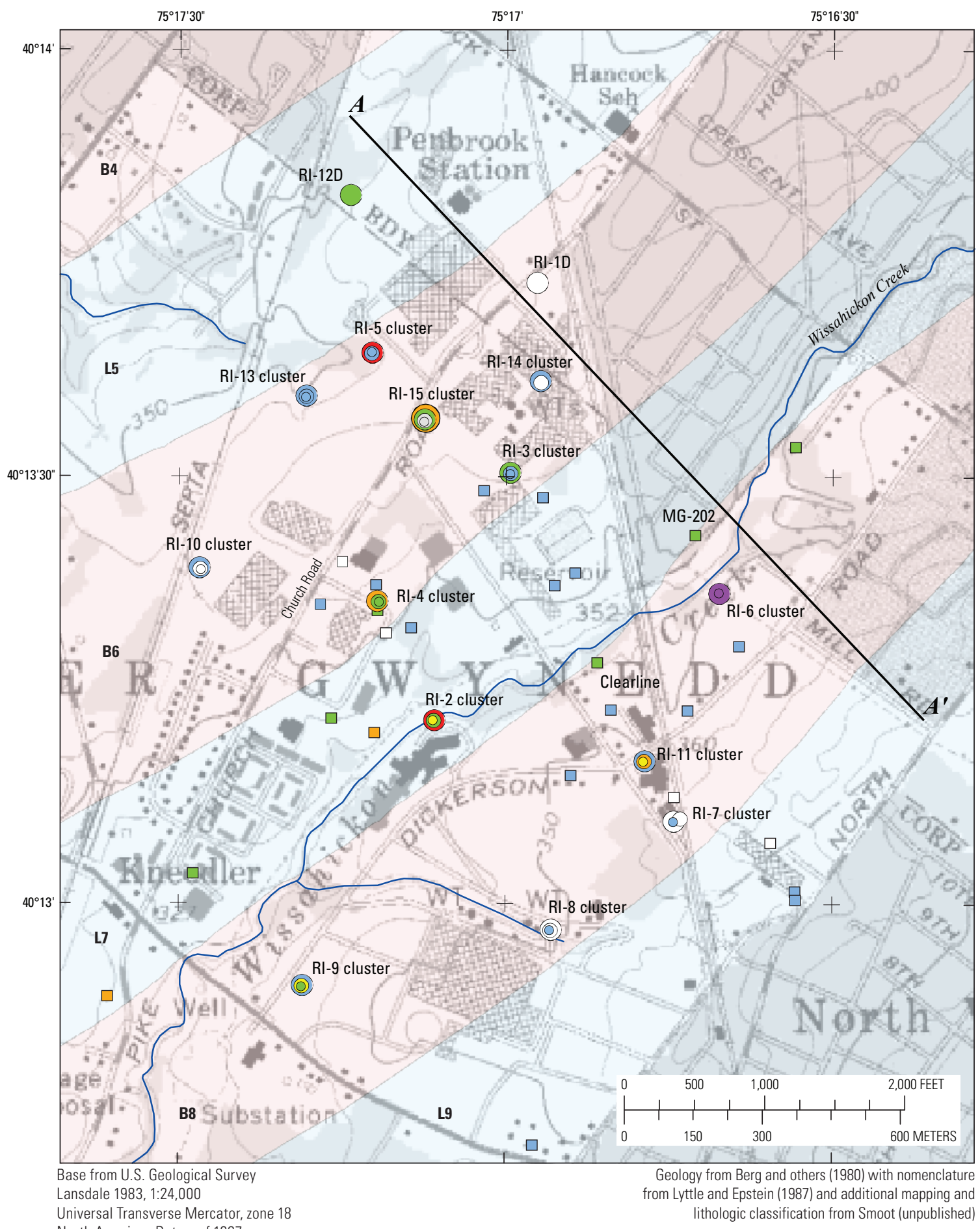

North American Datum of 1927

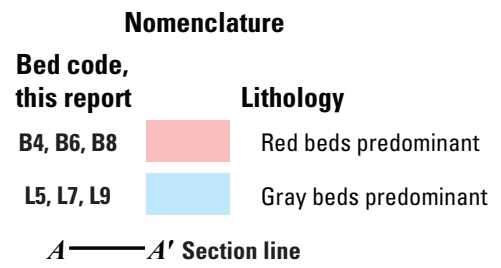

\section{EXPLANATION}

Type of well-Label is well (MG-) or cluster (RI-) identifier

- Shallow monitor

Intermediate monitor

Deep monitor

$\square \quad$ Open-hole existing well

\begin{tabular}{|c|c|c|c|}
\hline \multicolumn{4}{|c|}{$\begin{array}{l}\text { Boron concentrations in } \\
\text { groundwater samples (2006), } \\
\text { in micrograms per liter }\end{array}$} \\
\hline 0 & $0-20$ & 0 & 81-100 \\
\hline 0 & $21-40$ & 0 & $101-150$ \\
\hline 0 & $41-60$ & 0 & $151-230$ \\
\hline 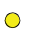 & $61-80$ & & \\
\hline
\end{tabular}

Figure 26. Boron concentrations in samples collected in spring 2006 from monitor well clusters and openhole wells, and line of section $A-A^{\prime}$, North Penn Area 7 Superfund site, Upper Gwynedd Township and vicinity, Montgomery County, Pennsylvania. 


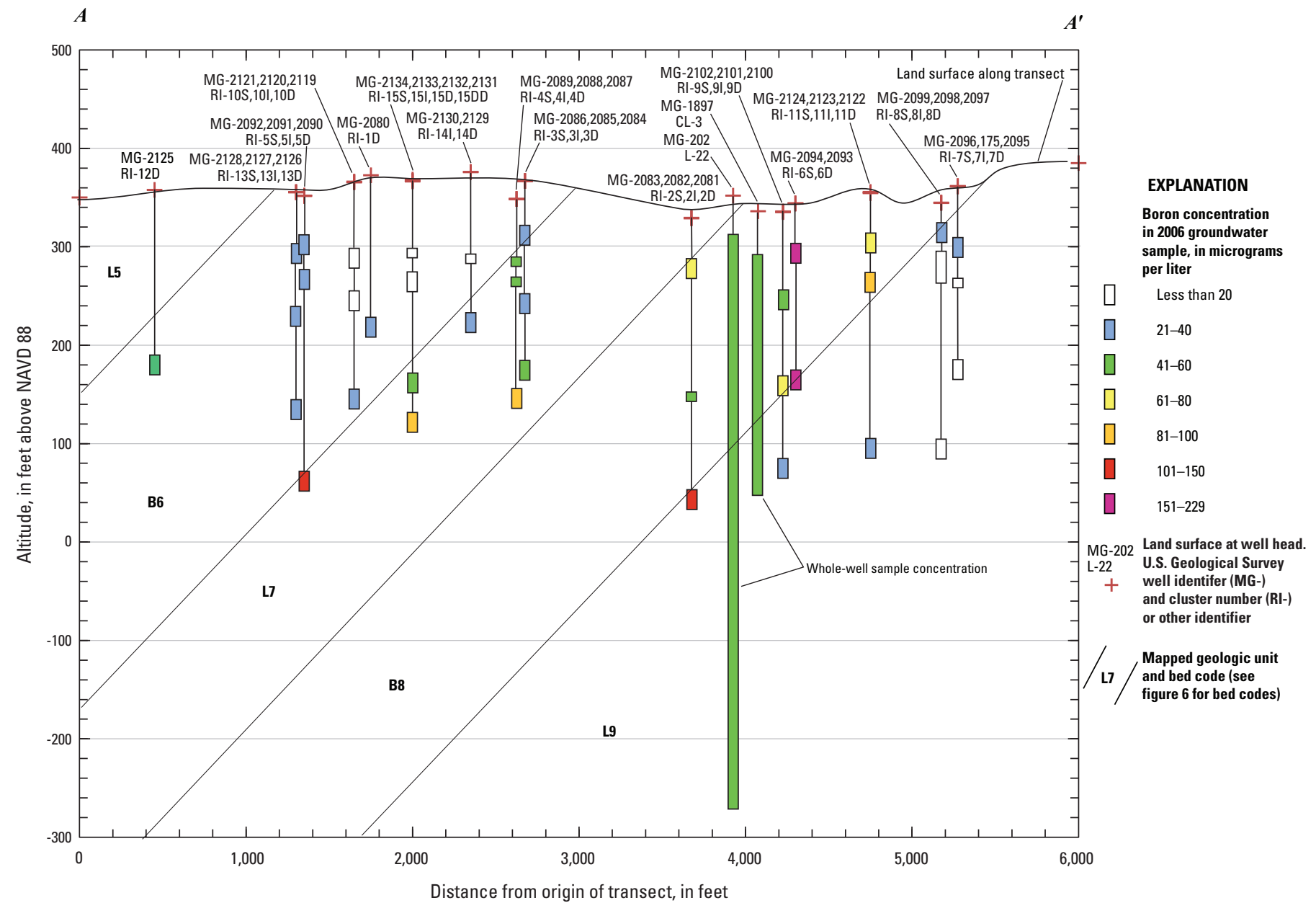

Figure 27. Locations of monitor wells projected onto a line parallel to dip and boron concentrations in samples collected from the monitor wells in spring 2006, North Penn Area 7 Superfund site, Upper Gwynedd Township and vicinity, Montgomery County, Pennsylvania. (See figure 26 for location of line of section.) 
identify different sources of elevated chloride at North Penn Area 7. Davis and others (1998) state that chloride/bromide mass ratios generally range from 50 to 150 in atmospheric precipitation, from 100 to 200 in shallow ground water, from 300 to 600 in domestic sewage, from 1,000 to 10,000 in water affected by dissolution of halite, and from 10 to 100 in summer runoff from urban streets.

In water samples collected from 70 wells at North Penn Area 7 in 2006, bromide concentrations were quantified in samples from 60 wells, ranging from 0.075 to $1.59 \mathrm{mg} / \mathrm{L}$, and concentrations were less than detection levels in samples from 10 wells (less than $0.075 \mathrm{mg} / \mathrm{L}$ in samples from 8 wells and less than $0.1 \mathrm{mg} / \mathrm{L}$ in samples 2 wells). In samples that had bromide concentrations reported at greater than the detection level, the 2006 chloride/bromide mass ratios ranged from 144 to 1,386 in two main groups of samples - those in which the chloride/bromide mass ratios increased almost linearly in relation to chloride concentrations and those in which chloride/ bromide mass ratios were relatively constant and (or) were independent of chloride concentration (fig. 28). The group for which the chloride/bromide mass ratios were independent of chloride concentration include shallow- and intermediatedepth monitor wells west of Church Road [MG-2092 (RI-5S), MG-2091 (RI-5I), MG-2121 (RI-10S), MG-2120 (RI-10I), MG-2128 (RI-13S), and MG-2127 (RI-13I)] and shallow open-hole wells along, but east of, Church Road at the Teleflex facility [MG-1149 (T-10), MG-1148 (T-12),] (figs. 28, 29). The spatial clustering of these wells indicates similar sources of chloride. Other groundwater samples with chloride/bromide mass ratios that appear relatively less strongly related to chloride concentrations were from several shallow wells at the Teleflex facility [MG-1146 (T-4), MG-1147 (T-11), MG-1842 (T-15), MG-1843 (T-6), and MG-2089 (RI-4S)], three nearby shallow wells [MG-2086 (RI-3S), MG-1847, and MG-2134 (RI-15S)], one well to the southwest of the RI-10 well cluster [MG-1537 (N1)], and two shallow wells east of Wissahickon Creek [MG-2099 (RI-8S) and MG-2102 (RI-9S) (figs. 28, 29). The spatial distribution of these other wells indicates (1) some

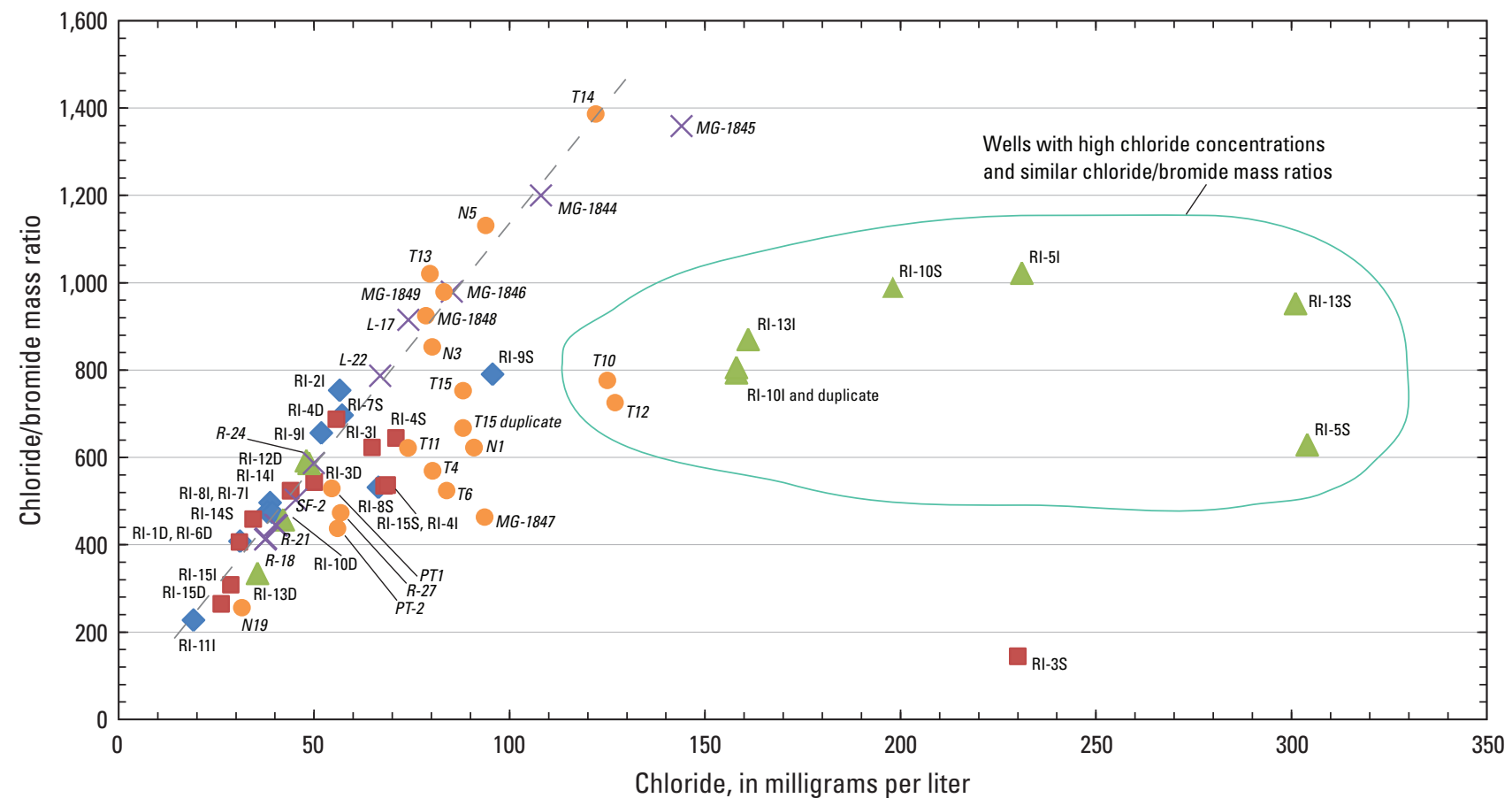

EXPLANATION

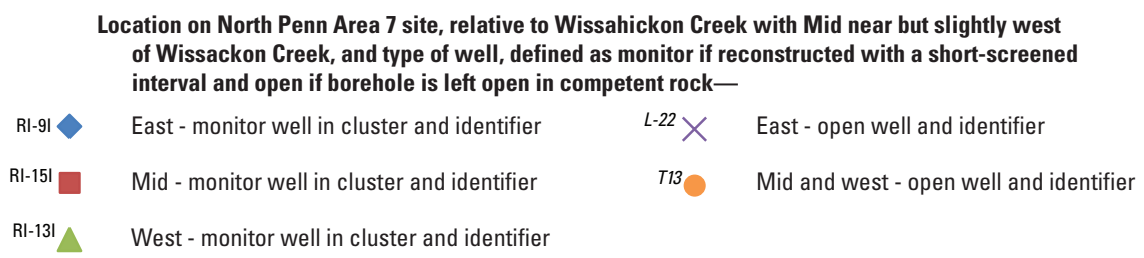

Figure 28. Chloride/bromide mass ratio in relation to chloride concentration in water samples collected in March 2006 from monitor wells at and near North Penn Area 7 Superfund site, Upper Gwynedd Township and vicinity, Montgomery County, Pennsylvania. (See figure 29 for location of wells.) 


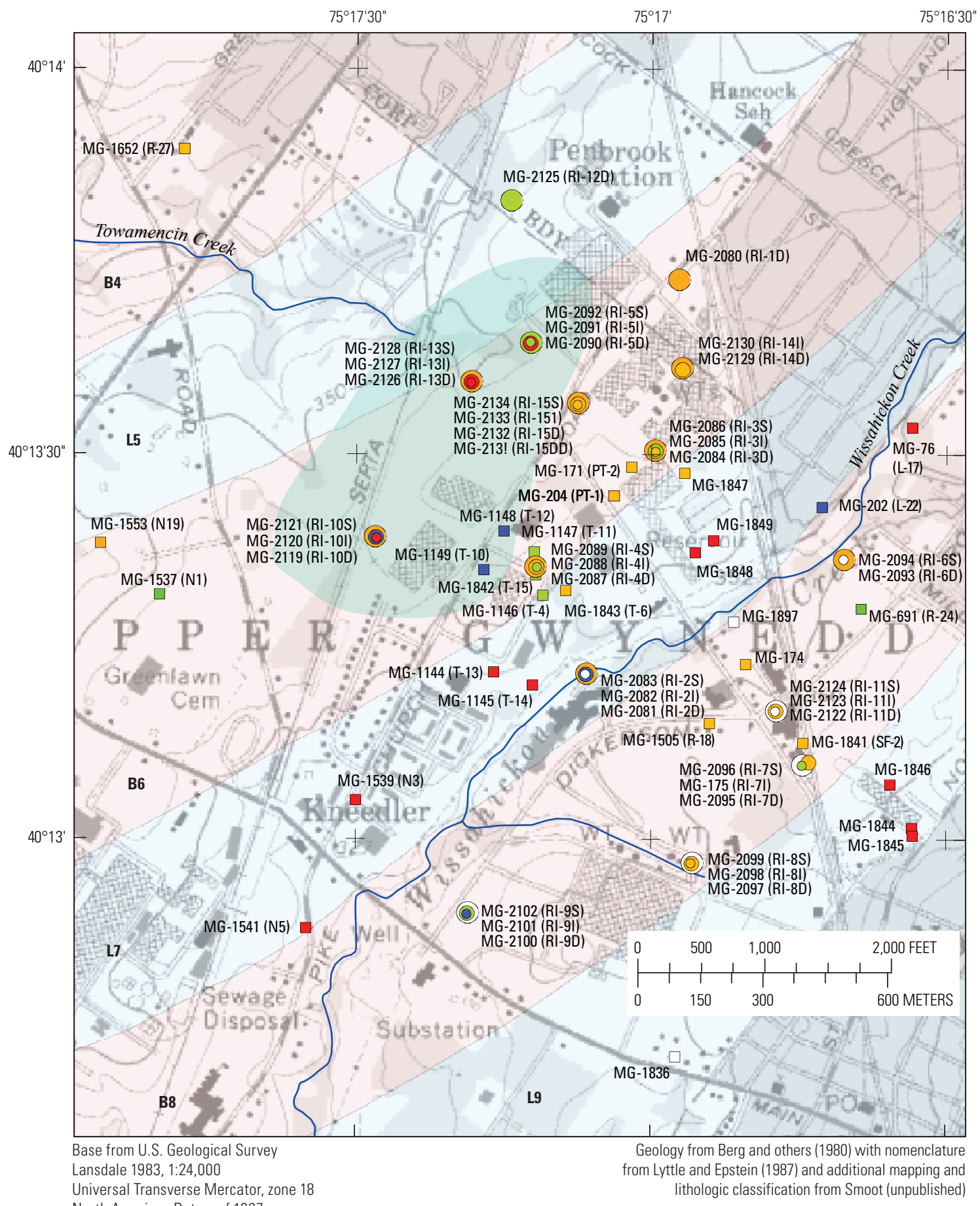

North American Datum of 1927

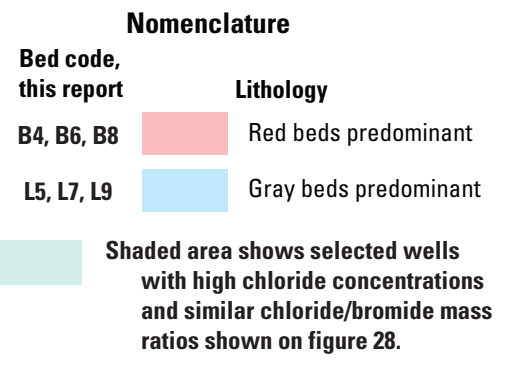

\begin{tabular}{lll}
$\begin{array}{l}\text { Type of well-Label is } \\
\text { well (MG-) or cluster (RI-) } \\
\text { or other identifier }\end{array}$ & $\begin{array}{c}\text { Chloride/bromide mass ratios } \\
\text { in groundwater samples (2006) }\end{array}$ \\
\hline & $\circ$ & Less than 0.1 or no data \\
Shallow monitor & $\circ$ & $0.1-550$ \\
Intermediate monitor & $\circ$ & $550.1-700$ \\
Deep monitor & $\bullet$ & $700.1-850$ \\
\hline$\quad$ Open-hole existing well & $\bullet$ & $850.1-1,390$
\end{tabular}

Figure 29. Spatial distribution of chloride/bromide mass ratios in water collected in March 2006 from monitor and existing open-hole wells, at and near North Penn Area 7 Superfund site, Upper Gwynedd Township and vicinity, Montgomery County, Pennsylvania. 
mixing of chloride sources occurs at and near the Teleflex facility, (2) unique sources of chloride are near MG-2086 (RI3S) and MG-2099 (RI-8S); and (3) groundwater flow is from shallow sources near the RI-5, RI-10, and RI-13 well clusters toward the southwest near well MG-1537 (N1). The remaining wells belong to the group for which chloride/bromide mass ratios increased almost linearly in relation to chloride concentrations, likely reflecting the introduction of bromide-poor salt, such as road salt or halite (sodium chloride), to the groundwater that has a natural background chloride/bromide mass ratio in the range of 100 to 150 .

\section{Inorganic Constituents as Tracers or Indicator of Lithology}

The 2005 and 2006 water samples from discrete isolated zones represented by the monitor well clusters at North Penn Area 7 showed that silica concentrations generally decreased with depth, indicating the presence of mechanisms for rapid recharge and (or) more reactive surfaces in shallower materials. Differences in silica concentrations across the site may be attributable to lithology to some extent, concentrations being higher overall in one of the predominantly red beds.

Like silica, chloride concentrations generally were higher in shallow zones. Chloride concentrations greater than the estimated natural background of about $10 \mathrm{mg} / \mathrm{L}$ were measured in most deep zones, indicating transport of recharge affected by surface applications of chloride (such as road salt or septic systems) to depths. The presence of chloride from surface sources may be used as a tracer and (or) surrogate for organic compounds or other constituents at the surface. Chloride/ bromide mass ratios indicate that sources of chloride in water from wells west of and along Church Road appear to differ from sources at other locations at North Penn Area 7 and probably include substances other than road salt.

Elevated boron concentrations (greater than $100 \mu \mathrm{g} / \mathrm{L}$ and up to $220 \mu \mathrm{g} / \mathrm{L}$ in RI-6D cluster) may be associated with flow paths from a source area or be associated with the lithology of beds that occur along Wissahickon Creek. The spatial distribution of boron concentrations in well-water samples appears to be related to the geologic structure, with the highest concentrations measured in samples from wells completed in units L7 and B8 (fig. 27), although it is unknown whether controls on the distribution are lithologic or hydrologic.

\section{Simulation of Regional Groundwater Flow}

A model using numerical simulation of regional groundwater flow at North Penn Area 7 was developed to (1) estimate regional-scale aquifer properties to better understand and describe the groundwater system and (2) provide a tool to estimate directions of groundwater flow (and contaminants transported in groundwater) under various historical and predictive scenarios.

\section{Estimation of Regional-Scale Aquifer Hydraulic Properties}

Hydraulic conductivity and storage are aquifer properties that may vary spatially because of geologic heterogeneity. Transmissivity, the hydraulic conductivity multiplied by the saturated thickness of the aquifer, represents a vertical average of hydraulic conductivities that may vary with depth. Estimation of these properties allows a quantitative prediction of the hydraulic response of the aquifer to recharge, pumping, and other hydrologic changes. Storage coefficients are important for understanding hydraulic response to transient stresses on aquifers. These properties can be estimated on a local scale by analysis of data from aquifer tests, such as single-well or multiple-well aquifer tests or on a regional scale by a numerical simulation of groundwater flow by use of a computer-based model. The local scale ranges from tens of feet to hundreds of feet. The regional scale is characterized by lengths of hundreds to thousands of feet.

Most of the analytical techniques used to estimate the hydraulic properties of aquifers were developed for porous media, such as unconsolidated sediments. These techniques may provide reasonable estimates of hydraulic properties in fractured rocks when the hydraulic response of the fracturedrock aquifers approximates porous media at the scale of interest. Previous application of this approach near the North Penn Area 7 Superfund site by Senior and Goode (1999) demonstrates that regional groundwater-flow properties can be estimated using porous media methods.

The regional-scale groundwater-flow model for North Penn Area 7 and vicinity described in this report assumes steady-state conditions and, therefore, can be used to estimate regional-scale hydraulic conductivities but not storage properties. Once hydraulic properties have been estimated, groundwater flow (and inferred advective transport of contaminants in groundwater) may be simulated to help describe and determine effects of pumping on the spatial distribution of contaminants in groundwater.

In the following section describing the model, both metric units and inch/pound units are given for convenience. Metric units were used for model input and output. However, all data used to construct and calibrate the model, except elevations from the digital elevation model (DEM), originally were collected, and in some cases presented elsewhere in this and previous reports, in inch/pound units.

\section{Numerical Simulation of Regional Groundwater Flow}

A three-dimensional finite-difference numerical model, MODFLOW-2000 (Harbaugh and others, 2000), was used to simulate regional steady-state flow. Model data were prepared using the Argus-ONE preprocessor (Agrus Interware, 1997) with a customized interface for preparing input files for and displaying model results from MODFLOW (Winston, 2000). 
The model was calibrated using automatic, nonlinear regression-based parameter estimation (optimization) and sensitivity algorithms incorporated in MODFLOW-2000 (Hill and others, 2000). Model parameters were adjusted to reduce the model error, which was computed from the differences between measured and simulated water levels and streamflow. MODPATH (Pollock, 1994) was used to calculate groundwater-flow paths and to plot the groundwater-flow paths on maps. S-Plus statistical software (Insightful Corporation, 2008) was used for Monte Carlo simulation using procedures developed by Starn and others (2010). ArcGIS (ESRI, 2006) was used to prepare maps of simulation results.

\section{Conceptual Model}

The model structure is based on a simplified conceptualization of the groundwater-flow system as understood from field investigations at North Penn Area 7 and previous studies. The weathered and fractured-rock formations are modeled as equivalent porous media, such as unconsolidated granular deposits. Thus, it is assumed that groundwater flow can be described using a three-dimensional flow equation based on Darcy's Law. In this approach, the hydraulic conductivities used in the model represent the bulk properties of the fractured-rock formations. Water flux, which may pass through only a small fraction of the rock mass occupied by fractures, is simulated as if it were distributed throughout all parts of the formations.

The regional-scale model presented here incorporates the effect of bed-oriented anisotropy, with generally lower hydraulic conductivity perpendicular to beds, by modeling the dipping stratigraphic beds (such as shown in fig. 15) with dipping model layers, as described by Goode and Senior (2000). Anisotropy refers to a dependence of hydraulic conductivity on direction. In contrast, under isotropic conditions, the hydraulic conductivity does not depend on direction. On the basis of field testing described in the previous section, the vertical hydraulic conductivity that is normal to the plane of bedding or "cross bed" is expected to be less than the subhorizontal hydraulic conductivity, which is oriented in the bedding plane. In addition, subhorizontal hydraulic conductivity anisotropy with different hydraulic conductivities in the dip and strike directions was incorporated for some parts of the model. As shown by Senior and Goode (1999), use of horizontal anisotropy approximates some features of groundwater flow in dipping sedimentary formations. The entire thickness of rock represented by each model layer is assumed to be saturated. This approximation means that the transmissivity, the product of the hydraulic conductivity and the saturated thickness, of the top model layer is assumed to be independent of the computed hydraulic head. In fact, the transmissivity of the shallow weathered zone is proportional to the saturated thickness of this unit. However, the model results are relatively insensitive to minor changes in the transmissivity of the weathered zone because most flow is in the deeper parts of the groundwater system. Where not affected by pumping, the depth to water in wells in the study area typically was less than 15 meters (m; $50 \mathrm{ft}$ ) and was less than $9 \mathrm{~m} \mathrm{(30} \mathrm{ft)} \mathrm{in} \mathrm{about} \mathrm{half} \mathrm{of} \mathrm{the} \mathrm{wells}$ measured in August 1996 (Senior and others, 1998).

As used here, MODFLOW-2000 calculates optimum values of model parameters, such as recharge rate and hydraulic conductivity, for a particular model structure on the basis of overall differences between simulated and observed water levels and streamflow. The model structure includes all quantitative information that establishes the functional relation between model parameters and simulated water levels and streamflow. Although properties of model cells can be specified individually, the approach used here was to group cells with similar properties into zones with uniform parameters. This approach significantly reduced the number of model parameters and improved the reliability of parameter estimates, although it generally reduced the model fit (Hill and Tiedeman, 2007). Zones, in this case primarily model layers, were delineated on the basis of hydrogeologic information, namely the regional bedrock geology as mapped at land surface, and the estimated regional dip angles for the rock formations. During model calibration, further grouping of model layers which are expected on the basis of hydrogeologic information to be similar and which are less sensitive to the observations, reduced the number of separate parameters. In addition, some model parameters that are shown to be very insensitive to the observations were removed from the automatic optimization for final calibration and sensitivity calculations. Thus, although the model in general calculates the optimum parameter values for each simulation, significant hydrogeologic judgment was used during the model construction and calibration to guide and control the calibration

\section{Model Structure and Boundary Conditions}

The model grid is aligned parallel to the regional strike of the dipping sedimentary beds (45 degrees NE) and corresponds to the assumed major axis of anisotropy of horizontal hydraulic conductivity (figs. 3 and 30). The assumed minor axis of anisotropy, therefore, is oriented generally in the dip direction. Cell dimensions of the horizontal model grid are $100 \mathrm{~m} \times 100 \mathrm{~m}(328 \mathrm{ft} \times 328 \mathrm{ft})$. Lateral boundaries of the model are defined as zero-flux (no flow) cells that include streams (discharge boundaries) and topographic divides that are assumed to be groundwater divides (fig. 30). Definition of the lateral boundaries is based, in part, on maps of water levels in the area (Senior and others, 1998; Senior and Ruddy, 2004).

The altitude of the top surface of the model is derived from 30-m digital-elevation-model (DEM) data with 30-m $(100-\mathrm{ft})$ grid spacing. The top of the model is defined as a constant flux boundary, where the flux into the model domain equals the recharge rate. The top two hydrogeologic units are conceptualized as a soil or colluvium unit and a highly weathered rock unit. These units have uniform thicknesses of $6 \mathrm{~m}(19.7 \mathrm{ft})$.

Beneath the subhorizontal soil and highly weathered rock units, the regional-scale model has a vertical structure 


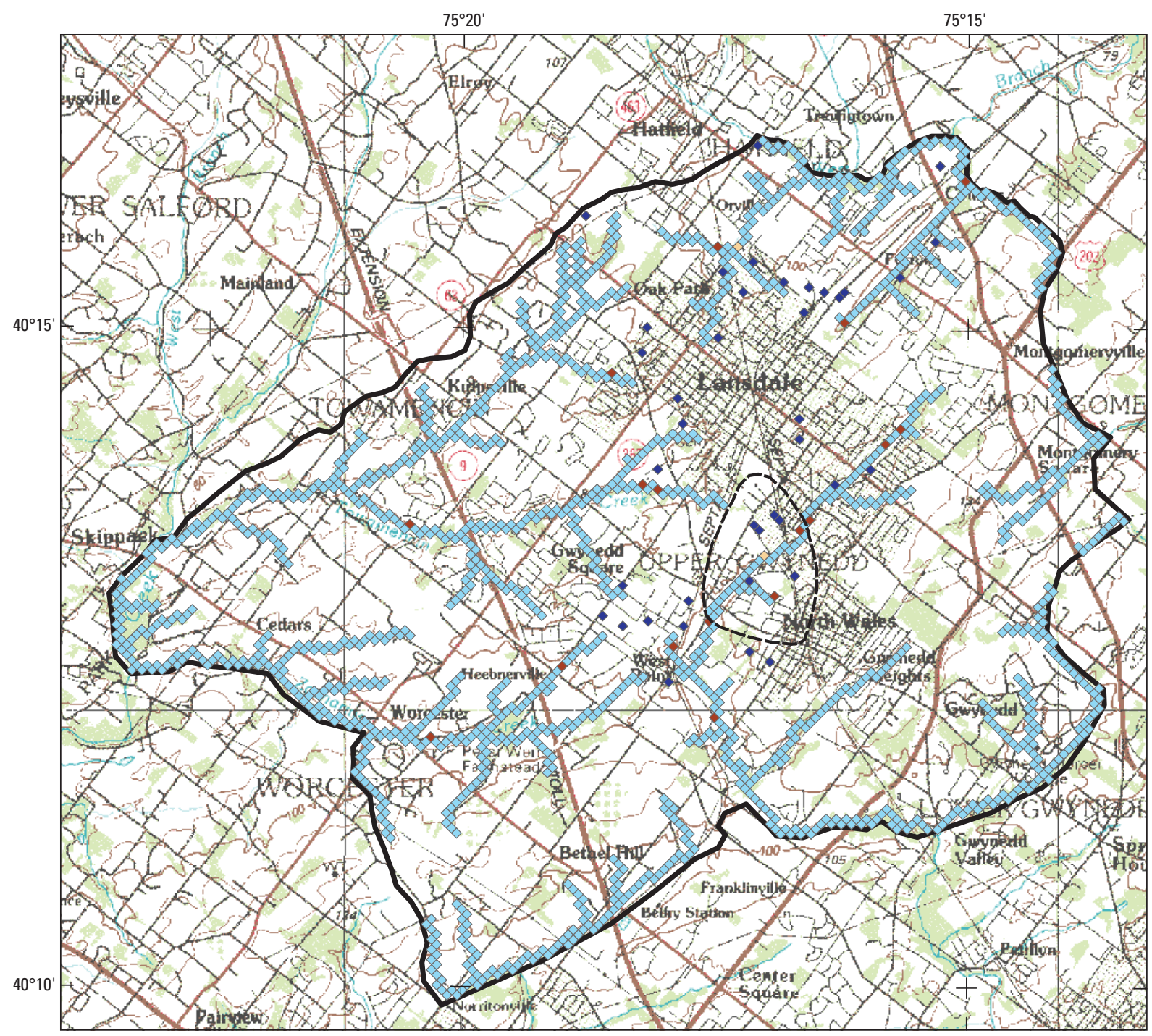

Base from U.S. Geological Survey

Reading, Pennsylvania-New Jersey 1984, 1:100,000

Figure 30. Model boundary, streams cells, and pumped well cells for model of North Penn Area 7 Superfund site, Upper Gwynedd Township and vicinity, Montgomery County, Pennsylvania. 
that mimics the dipping stratigraphy of the geologic units, as defined by geologic mapping in the area and by correlations between borehole logs (Senior and others, 2008). The model preprocessor computes appropriate layer elevations and thicknesses and assigns the corresponding model parameters. The geologic structure is simulated using contours of elevation on the top of the uppermost (to the NW) dipping bed, B4, corresponding to model layer 4 (table 3 ). The contour lines were digitized from the surface geology map of Smoot (Joseph P. Smoot, written communication, 2006). Starting from the contact contour of the top of bed B4, which is at the elevation of the land surface, the assumed regional dip of 10 degrees to the NW was used to extrapolate the elevation of the top of bed B4 throughout the model domain, updip and downdip from the contact contour. Note that in updip areas parts or all of this bed have been eroded. Approximate bed thicknesses were calculated geometrically for each bed from the geologic-contact contour horizontal spacings. These thicknesses were used to compute the structural contour elevations for the top of the each bed.

Using the depth of the weathered zone and the assumed lower boundary of the model, the model layers representing the beds are truncated at the top and bottom (figs. 31, 32). The upper truncation occurs where each bed represented by a model layer subcrops below the subhorizontal highly weathered rock layer or $12 \mathrm{~m}(39.4 \mathrm{ft})$ below the land surface. At this interface, truncated bedrock layers are assigned a thickness of $0.01 \mathrm{~m}(0.033 \mathrm{ft})$, and the hydraulic properties are those of the overlying highly weathered rock layer. In areas where model layers representing beds are truncated near the surface, the thickness of the overlying highly weathered rock unit is thus slightly increased, but the increase does not significantly affect the estimation of aquifer properties or regional flow results. The lower truncation is at the bottom of the model, $200 \mathrm{~m}$ ( $656 \mathrm{ft})$ beneath the bottom of the highly weathered rock layer, or $212 \mathrm{~m}(695 \mathrm{ft})$ below the land surface. Model cells truncated at the bottom are inactive cells and are not included in the simulation. The bottom layer of the model is defined as a no-flow boundary.

In summary, the model structure is similar to the regional-scale model of Senior and Goode (1999) but with dipping model layers to represent mapped dipping sedimentary units. Computations of model layer top and bottom elevations and specification of model cell properties are performed

Table 3. Hydrostratigraphy used in the groundwater model for North Penn Area 7 Superfund site, Upper Gwynedd Township and vicinity, Montgomery County, Pennsylvania.

$[\mathrm{m}$, meters $]$

\begin{tabular}{|c|c|c|c|c|c|c|c|c|}
\hline \multirow[b]{2}{*}{ Geologic unit } & \multirow[b]{2}{*}{$\begin{array}{l}\text { Bed code } \\
\text { for model }\end{array}$} & \multirow[b]{2}{*}{$\begin{array}{c}\text { Geologic } \\
\text { map } \\
\text { symbol }\end{array}$} & \multirow[b]{2}{*}{$\begin{array}{c}\text { Lithologic } \\
\text { map } \\
\text { symbol }\end{array}$} & \multirow[b]{2}{*}{$\begin{array}{l}\text { Model } \\
\text { layer }\end{array}$} & \multirow[b]{2}{*}{$\begin{array}{l}\text { Thickness }^{3} \\
(\mathrm{~m})\end{array}$} & \multicolumn{3}{|c|}{ Hydraulic conductivity parameters } \\
\hline & & & & & & $\begin{array}{l}\text { Value in } \\
\text { strike } \\
\text { direction }\end{array}$ & $\begin{array}{c}\text { Horizontal } \\
\text { anisotropy }\end{array}$ & $\begin{array}{c}\text { Vertical } \\
\text { anisotropy }\end{array}$ \\
\hline \multicolumn{9}{|c|}{ Subhorizontal units (uniform thickness) } \\
\hline Overburden & & & & 1 & 6 & KW & 1 & 1 \\
\hline Highly-weathered rock & & & & 2 & 6 & $\mathrm{KW}$ & 1 & 1 \\
\hline \multicolumn{9}{|c|}{ Dipping units (varying thickness) } \\
\hline Brunswick Group - undifferentiated & $\mathrm{B}$ & JTrb & TrSic & 3 & 200 & KB & HANI & VANI \\
\hline Red beds predominant - deltaic & B4 & $\mathrm{JTrb}$ & $\mathrm{TrS} / \mathrm{Sic}$ & 4 & 80 & KB46 & HANIBED & VANIBED \\
\hline Gray beds predominant - deltaic & L5 & JTrblg & $\mathrm{TrS} / \mathrm{Sicg}$ & 5 & 83 & KL5 & HANIBED & VANIBED \\
\hline Red beds predominant - deltaic & B6 & $\mathrm{JTrb}$ & $\mathrm{TrS} / \mathrm{Sic}$ & 6 & 140 & KB46 & HANIBED & VANIBED \\
\hline Gray beds predominant - deltaic & L7 & JTrblg & $\mathrm{TrS} / \mathrm{Sicg}$ & 7 & 57 & KL7 & HANIBED & VANI7 \\
\hline Red beds predominant - deltaic & B8 & $\mathrm{JTrb}$ & $\mathrm{TrS} / \mathrm{Sic}$ & 8 & 74 & KB8 & HANIBED & VANI8 \\
\hline Gray beds predominant - deltaic & L9 & $\operatorname{Trl}$ & $\mathrm{TrS} / \mathrm{Sicg}$ & 9 & 233 & KL9 & HANIBED & VANIBED \\
\hline Red beds predominant - deltaic & B10 & Trlr & $\mathrm{TrS} / \mathrm{Sic}$ & 10 & 47 & KB10 & HANIBED & VANIBED \\
\hline Lockatong Formation - undifferentiated & $\mathrm{L}$ & $\operatorname{Trl}$ & TrSicg & 11 & 200 & KL & HANI & VANI \\
\hline
\end{tabular}

${ }^{1}$ Lyttle and Epstein, 1987.

${ }^{2}$ Joseph Smoot, U.S. Geological Survey, unpublished mapping, 2005.

${ }^{3}$ Thickness used in model for layers 3-11 depends on location with respect to dipping beds. Maximum stratigraphic thickness of layer listed. Total thickness of layers $3-11$ is limited to $200 \mathrm{~m}$.

${ }^{4}$ Hydraulic conductivity in the dip direction divided by the value in the strike direction.

${ }^{5}$ Hydraulic conductivity in the strike direction divided by the value in the vertical direction. 


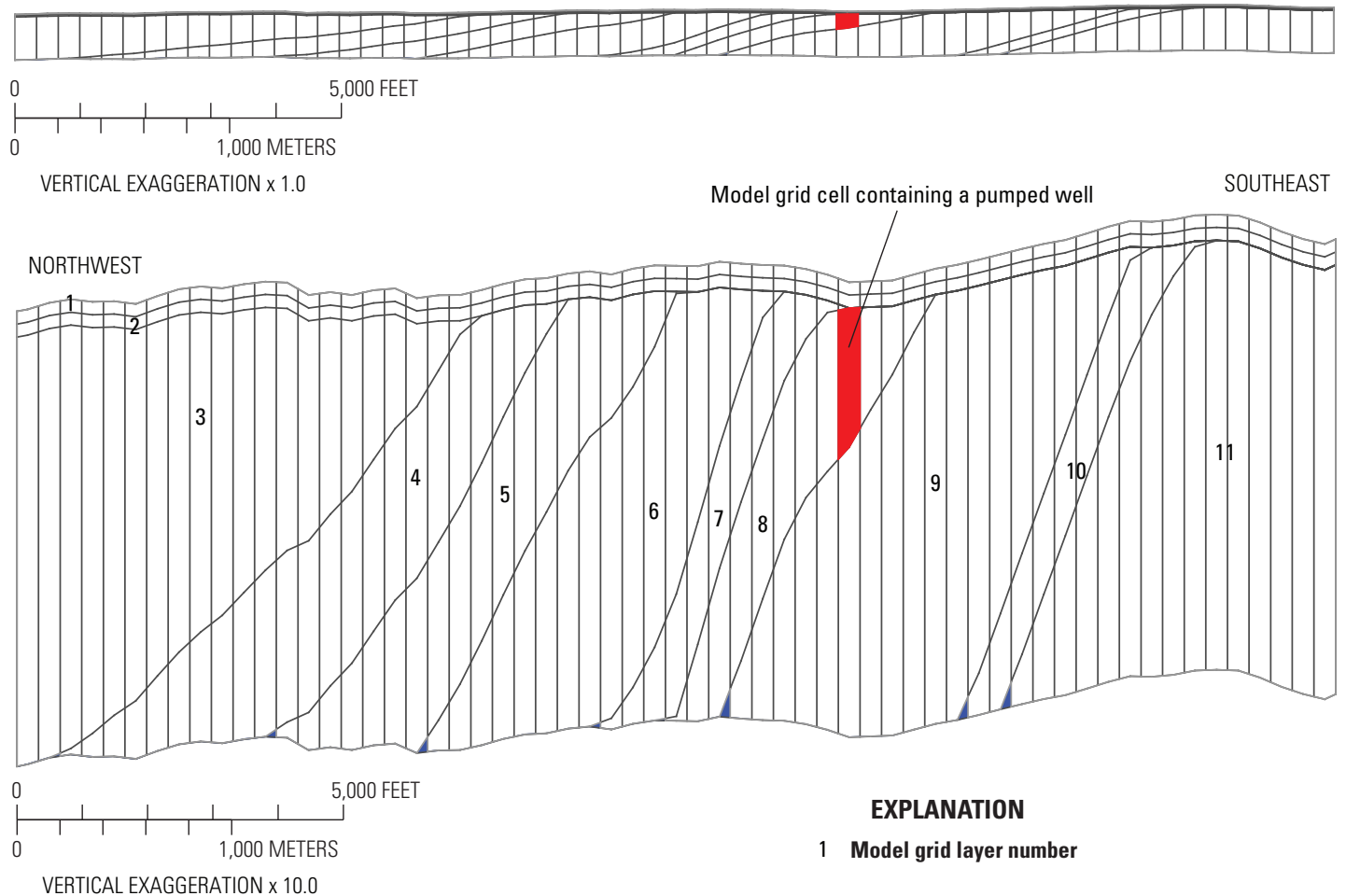

Figure 31. Cross section in the dip direction of model grid for North Penn Area 7 Superfund site, Upper Gwynedd Township and vicinity, Montgomery County, Pennsylvania. (See figure 33 for location of lines of section.)

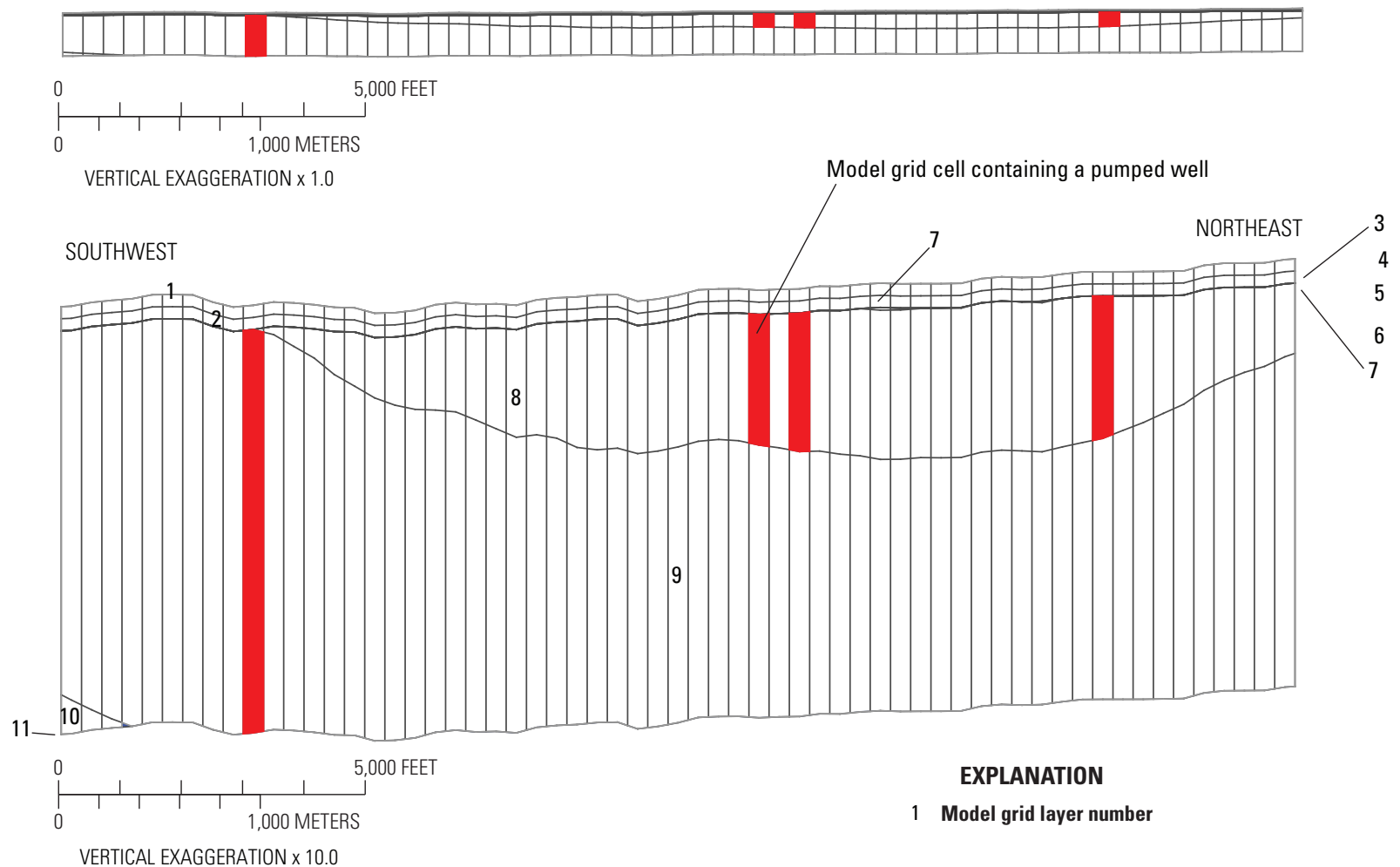

Figure 32. Cross section in the strike direction of model grid for North Penn Area 7 Superfund site, Upper Gwynedd Township and vicinity, Montgomery County, Pennsylvania. (See figure 33 for lines of section.) 
by a preprocessor using a programmed geographic information system (GIS) (Winston, 2000). This approach yields dipping model layers whose geometry conforms to the mapped geologic units in the study area (fig. 33) and are pinched out where these beds have been eroded or subcrop within the weathered zone.

This model is constructed to simulate regional features of groundwater flow in the study area and is not designed to simulate features of groundwater flow observed during local-scale testing. In contrast to the model of Goode and Senior (2000), in which thin dipping layers a couple of meters thick represent individual bed-oriented flow features, the present model has dipping layers that represent larger hydyrostratigraphic units and do not represent individual high-transmissivity zones. The thinnest model layer (representing fractured-bedrock units) used here is $47 \mathrm{~m}$ thick, whereas field testing indicates that high-transmissivity features in boreholes are generally less than $1 \mathrm{~m}$ thick.

\section{Calibration Methods}

The numerical model is calibrated by use of parameterestimation components of MODFLOW-2000 (Hill and others, 2000) that minimize model error through a linearized gradient method. During parameter estimation, an iterative procedure is used to adjust aquifer hydraulic properties in the model

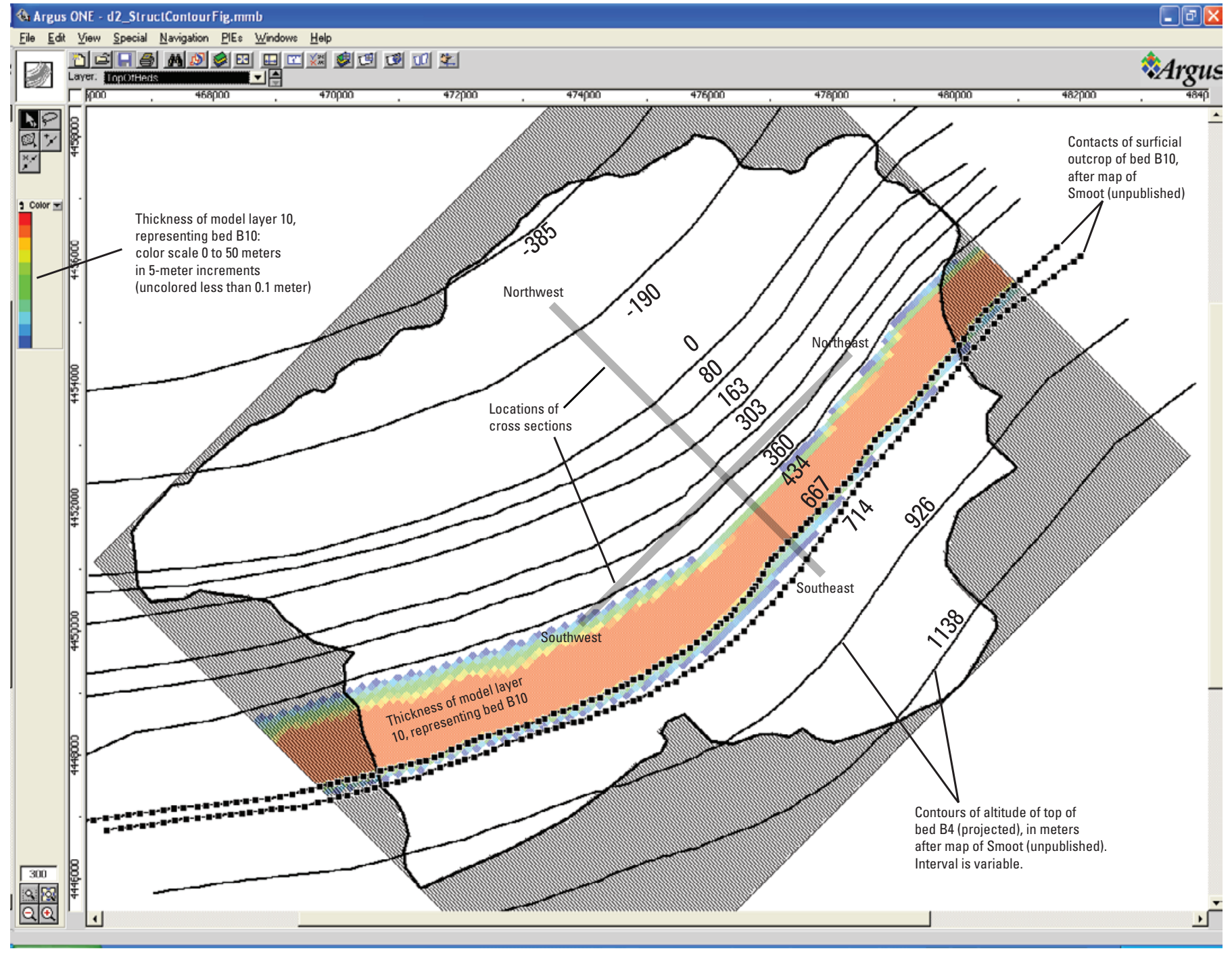

Figure 33. Model preprocessor showing structural contours for top of bed B4 (projected), layer 10 thickness for the model, and lines of section, North Penn Area 7 Superfund site, Upper Gwynedd Township and vicinity, Montgomery County, Pennsylvania. Cross sections for depicted section lines shown on figure 31. 
in such a way as to minimize an overall model error. Model error is defined as the sum of squared, weighted residuals, where residuals are the differences between measured and simulated hydraulic head (water level) and streamflow. These residuals are weighted to account for differences in units, for example between units of meters for water-level measurements and units of cubic meters per day $\left(\mathrm{m}^{3} / \mathrm{d}\right)$ for streamflow. The weight for all water-level measurements is 1.0 (in units of $1 / \mathrm{m})$, and the weight for all streamflow residuals is 0.058 [in units of days per cubic meter $\left(\mathrm{d} / \mathrm{m}^{3}\right)$ ] (Senior and Goode, 1999, p. 76).

The model was calibrated using measured groundwater levels (317 values), measured streamflows (10 values), and specified pumping rates for three time periods. The calibration procedure computes the total model error as the sum of the errors for each simulation period and uses a consistent set of hydraulic parameters for all simulations. The time periods used for model calibration were August 1996 (Senior and others, 1998; Senior \& Goode, 1999), December 2000 (Senior and Ruddy, 2004), and June 2005 (Senior and others, 2008). Although water levels fluctuate seasonally and typically are lowest in late summer/early fall and highest in spring, the pattern of rainfall prior to each set of synoptic measurements evened out the differences related to seasonal timing of measurements. The regional groundwater levels in each set of synoptic measurements were near long-term (30year) annual averages (fig. 19). Compared to the long-term (30-year) precipitation normals, the hydrologic conditions during these periods were relatively wet prior to August 1996 and near the long-term average prior to December 2000 and June 2005 (Senior and others, 2008). During calibration, the recharge during the three time periods (1996, 2000, and 2005) was specified as three independent model parameters. The conductivity of the streambed, which controls the head gradient between the aquifer and the stream, provided the stream is flowing, was an estimated model parameter.

External procedures were used to guide and control the parameter estimation process. During initial calibration, several model parameters were identified that were relatively insensitive to the observations. That is, large changes in the model parameter value had relatively small effects on the overall model error. For example, the limited observations (14 monitor well clusters) of the vertical head gradient limits the sensitivity of the model error to vertical anisotropy. Hydrogeologic judgment was used to remove such parameters from the automatic calibration. In several cases, initial calibrations were used to identify a model parameter value that was reasonable on the basis of hydrogeologic judgment and field observations and that yielded a low model error. Subsequently, these parameter values were fixed and removed from the calibration process. Parameters estimated using this procedure also were not used in Monte Carlo simulations. The estimates of these parameters are considered to have high uncertainty.

Final parameter values were estimated using a combination of manual and automatic optimization procedures. Automatic calibration successfully reduced the overall model error by adjusting parameters from their initial values. However, near the optimum, the gradient search method failed to converge. There may be several aspects of this particular application that cause this, including numerous and sometimes poorly constrained parameters and nonlinear behavior of the groundwater-flow model and optimization. Separate optimizations were conducted with many different sets of parameters fixed, and in some cases, all but one parameter was fixed. However, even in this case the overall model error increased during the automatic calibration when starting close to the optimum value. The final parameter values presented here were eventually identified by picking, by hand, the model parameter set that produced the lowest overall model error from among the trials conducted near the optimum. Although these values are not guaranteed to be the absolute optimum parameter values possible, the parameter values identified are considered close enough to the true optimum to be used for reasonably accurate simulation. This uncertainty is considered acceptable given the other uncertainties in the model. It may be possible to use alterative optimization procedures beyond the gradient search method that may yield slightly different optimum parameter values, but the application presented here is limited to the procedures in MODFLOW-2000 (Hill and others, 2000).

\section{Recharge and Discharge}

The components of the water budget for the saturated zone that are included in the model are (1) uniform recharge to the water table, (2) discharge to pumped wells, and (3) discharge to, and infiltration from, streams. The steady-state assumption implies that these fluxes are in equilibrium and that hydraulic head is not changing in time. In reality, these fluxes, particularly pumping rates and recharge, are changing in time, and hydraulic head changes in response to these fluctuations. The steady-state model corresponds to the average flow conditions for the time period of interest and approximates the average fluxes and hydraulic head during that period. Thus, the steady-state model does not and cannot simulate instantaneous flow conditions.

Recharge to the saturated zone is assumed to be spatially uniform because detailed spatial information on factors affecting infiltration is not available for the study area. On average, recharge to the water table is precipitation minus surface runoff and evapotranspiration. Areal recharge enters through the top model layer, and the magnitude of recharge is determined from calibration. An average, the annual recharge rate of 210.8 millimeters per year (mm/yr; 8.3 inches per year (in/yr)) estimated by Senior and Goode (1999) for the Lansdale area, was used as an initial estimate in this model. Recharge was not varied spatially according to differences in land use or topography. Three separate parameters were used for the recharge in 1996, 2000, and 2005, named Rech1996, Rech2000, and Rech2005, respectively.

Streams are simulated in the model by use of the stream package (Prudic, 1989) as modified for MODFLOW-2000. Streams are in the shallow top layer of the model, and the 
aquifer discharges to the stream if the hydraulic head in a model cell is higher than the hydraulic head of the stream in that cell. The stream package allows simulated streams to gain or lose water and accounts for the flow in each stream cell so that losses cannot exceed the simulated base flow of the stream. Land-surface elevations from the $10-\mathrm{m}$ digital elevation model (DEM) were interpolated to points along each stream. Stream stage was assigned an altitude $1 \mathrm{~m}$ lower than the interpolated land-surface elevation. The thickness of the streambed was assumed to be $2 \mathrm{~m}(6.6 \mathrm{ft})$. Stream width was assumed to be $3 \mathrm{~m}(9.8 \mathrm{ft})$. The location of streams in the model domain and interpolated land-surface elevation at streams are shown in figure 34. The uniform streambed conductivity parameter (STR) was estimated during calibration.

Values for aquifer discharge to streams are derived from 25 measurements of base flow made at five locations from May 1995 through November 1996 (Senior and Goode, 1999, table 4) and from measurements made at several locations on Wissahickon Creek from June 2000 to September 2005 (Senior and others, 2005, table 65; Senior and others, 2008, tables 74 and 75) (fig. 20). Base-flow measurements used to estimate groundwater discharge to the stream at various time periods of the simulation were available at several streams for the 1996 calibration period but only at Wissahickon Creek for the 2000 and 2005 calibration period (table 4). Comparison of

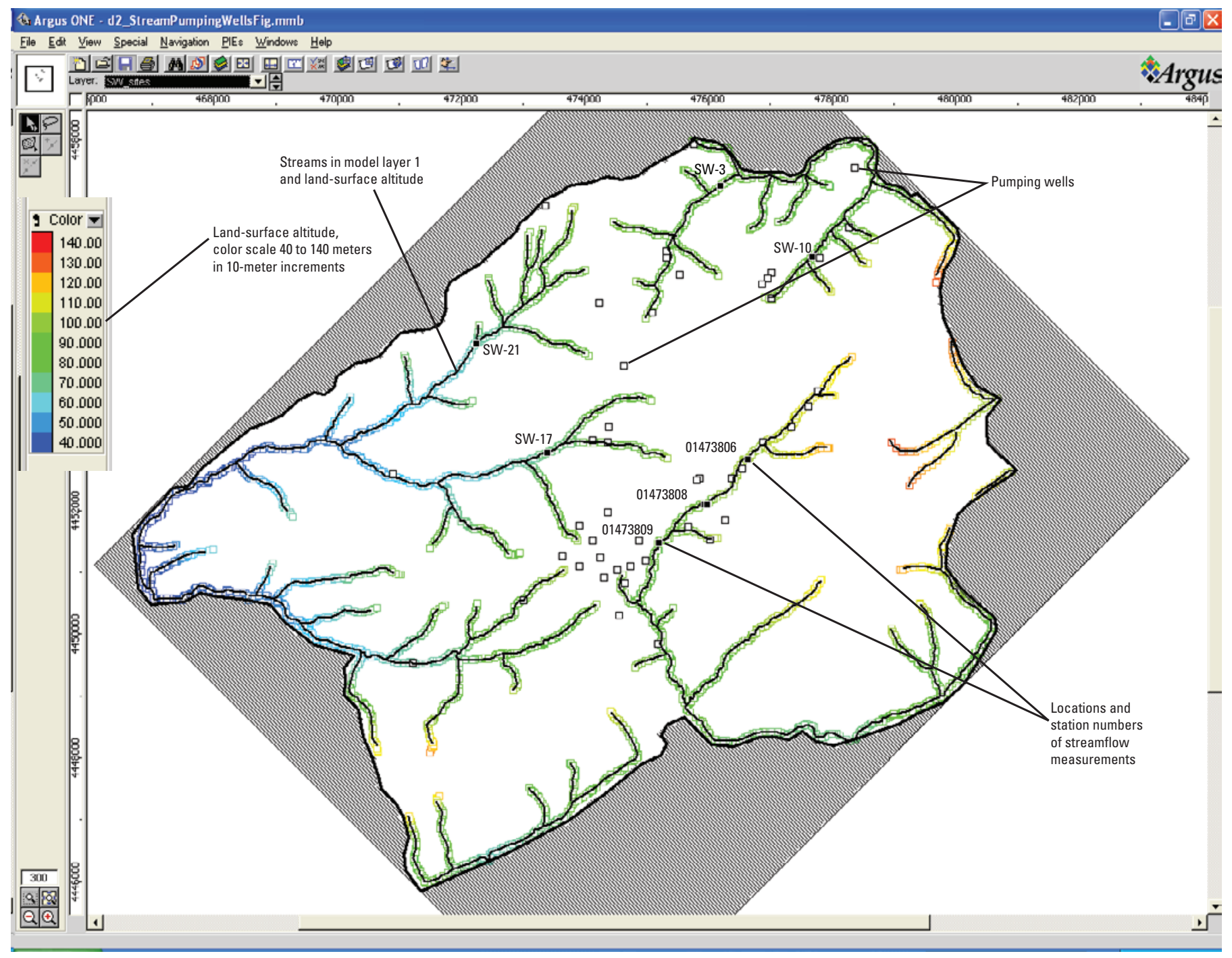

Figure 34. Model preprocessor showing locations of streamflow measurements, land-surface elevations at streams, and locations of pumped wells for the numerical model for North Penn Area 7 Superfund site, Upper Gwynedd Township and vicinity, Montgomery County, Pennsylvania. 
measured and simulated streamflow for 1996, 2000, and 2005 simulation periods is shown in table 4 , which lists the measured and simulated incremental change in streamflow, that is the net discharge from the aquifer to the stream (gain) or flow from the stream to the aquifer (loss) for a given stream reach. Measured streamflows were relatively well-simulated by the model in 1996 for streams other than Wissahickon Creek. Residuals (simulated-measured) for Wissahickon Creek in all calibration periods (1996, 2000, and 2005) were larger than those in 1996 for other streams (table 4).

Groundwater withdrawals from wells are represented by a constant flux of water removed from the model using the multi-node well (MNW) package in MODFLOW-2000. Withdrawals from each well are computed for all model layers representing beds to which the well is open. An iterative procedure ensures that the sum of the layer fluxes for a given well is equal to the well pumping rate, within a user-specified tolerance. Locations of pumped wells used in model simulations are shown in figure 34. Well information and pumping rates for calibration periods are shown in table 5 .

The pumping rates used in the model represent annual average rates (Pennsylvania Department of Environmental Protection, State Water Plan Division, written commun., 1995), except for some NPWA wells (table 5). NPWA wells were assigned the average pumping rate for the month of interest, if monthly data were available.

\section{Measured and Simulated Water Levels in Wells}

A total of 317 measured water levels in 215 wells within the model domain were available for three different time periods (table 6 , at end of report). The periods used for model calibration are August 1996 (Senior and others, 1998; Senior and Goode, 1999), December 2000 (Senior and Ruddy, 2004), and June 2005 (Senior and others, 2008). Water-level data consist of one measurement per well for each period. The water-level data were distributed over a larger area for the 1996 calibration (139 wells) than for the 2000 calibration (95 wells) and the 2005 calibration ( 84 wells); data for the 2000 and 2005 calibration periods were spatially centered on North Penn Area 7 and vicinity. A simultaneous calibration was performed using steady-state models for each of the periods. On the basis of specified altitudes of the top and bottom of the open interval of each well, the model preprocessor determined the corresponding model layers for each well and, if needed, thickness-proportional layer weights. In the latter case, the measured water level was compared to a weighted vertical average of the simulated water levels in the model layers that intersect the open interval of the well.

Maps of simulated water-table altitudes (water levels in top layer of model representing the weathered zone) are shown for the three calibration periods, 1996, 2000, and 2005 (fig. 35). The simulated water-table contours are similar to potentiometric-surface maps prepared from measured water levels in wells completed at various depths (Senior and Goode, 1999; Senior and Ruddy, 2004; Senior and others, 2008).

Groundwater-level residuals (simulated water level minus the measured water level) for wells with measurements also are shown on these maps for the three calibration periods, 1996, 2000, and 2005 (fig. 35). The root mean square residuals for the 1996, 2000, and 2005 calibration periods are 5.53, 4.86 , and $4.54 \mathrm{~m}$ (18.1, 16.0 and $14.9 \mathrm{ft})$, respectively. The residuals show that many simulated groundwater levels are close in value to measured levels and indicate that there are some clusters of over-simulated and under-simulated groundwater levels. The groundwater levels at several locations in the northern part of the modeled area are under-simulated for 1996 by the model (fig. 35). This northern area is far from the contamination in the North Penn Area 7 and is modeled as a single hydrogeologic unit of the Brunswick Group, after Senior and Goode (1999). Additional effort to add heterogeneity and parameters in this part of the model was not attempted in the present study but could be attempted in future model applications to reduce model error for that area. Simulated water levels for several wells in the vicinity of the Merck facility are too high by more than $5 \mathrm{~m}(16.4 \mathrm{ft})$ for all three time periods and too low by more than $5 \mathrm{~m}(16.4 \mathrm{ft})$ for 2005 , which may be due to higher or lower than average pumping rates, respectively, at the time of the water-level measurement. In addition, the local-scale heterogeneity that has been observed during aquifer tests at the Merck facility (Goode and Senior, 1998) and in Lansdale (Goode and Senior, 2000) was not incorporated in the present regional-scale model.

The relation of simulated groundwater levels to measured groundwater levels indicates that the groundwater-flow model generally captures the regional characteristics of groundwater flow (fig. 36). The overall root-mean-square water-level residual is $5.02 \mathrm{~m}(16.5 \mathrm{ft})$ for the three calibration periods, which is small in comparison to the range of measured water level altitudes as great as $115 \mathrm{~m}(377 \mathrm{ft})$. However, the residuals at individual wells range from $-21.6 \mathrm{~m}(-70.8 \mathrm{ft})$ to $+16.7 \mathrm{~m}$ $(+54.8 \mathrm{ft})$, indicating that the simulation error at individual well locations may be large. Residuals (or model errors) are among the largest for water levels in wells affected by pumping, such as those at the Merck facility or in the RI-2 and RI-9 well clusters, indicating that, locally, the model sometimes did not closely simulate the observed vertical gradient determined using measured water levels in well clusters. The direction, but not the magnitude, of the vertical gradients generally were correctly simulated in the areas affected by pumping. This result is due, in part, to two factors - (1) inaccurate pumping rates, annual or monthly average pumping rates were used in the steady-state simulation, but measured water levels reflect possibly different daily or hourly rates and (2) the model structure in which occasionally more than one well in a cluster, each with its own water level, may be in the same model cell, making accurate simulation of water levels impossible. For example, in 2005, the measured water levels were about $10 \mathrm{~m}$ (33 ft) lower in the intermediate well [MG-2101 (RI-9I)] than the deep well [MG-2100 (RI-9D)] of the RI-9 cluster because 


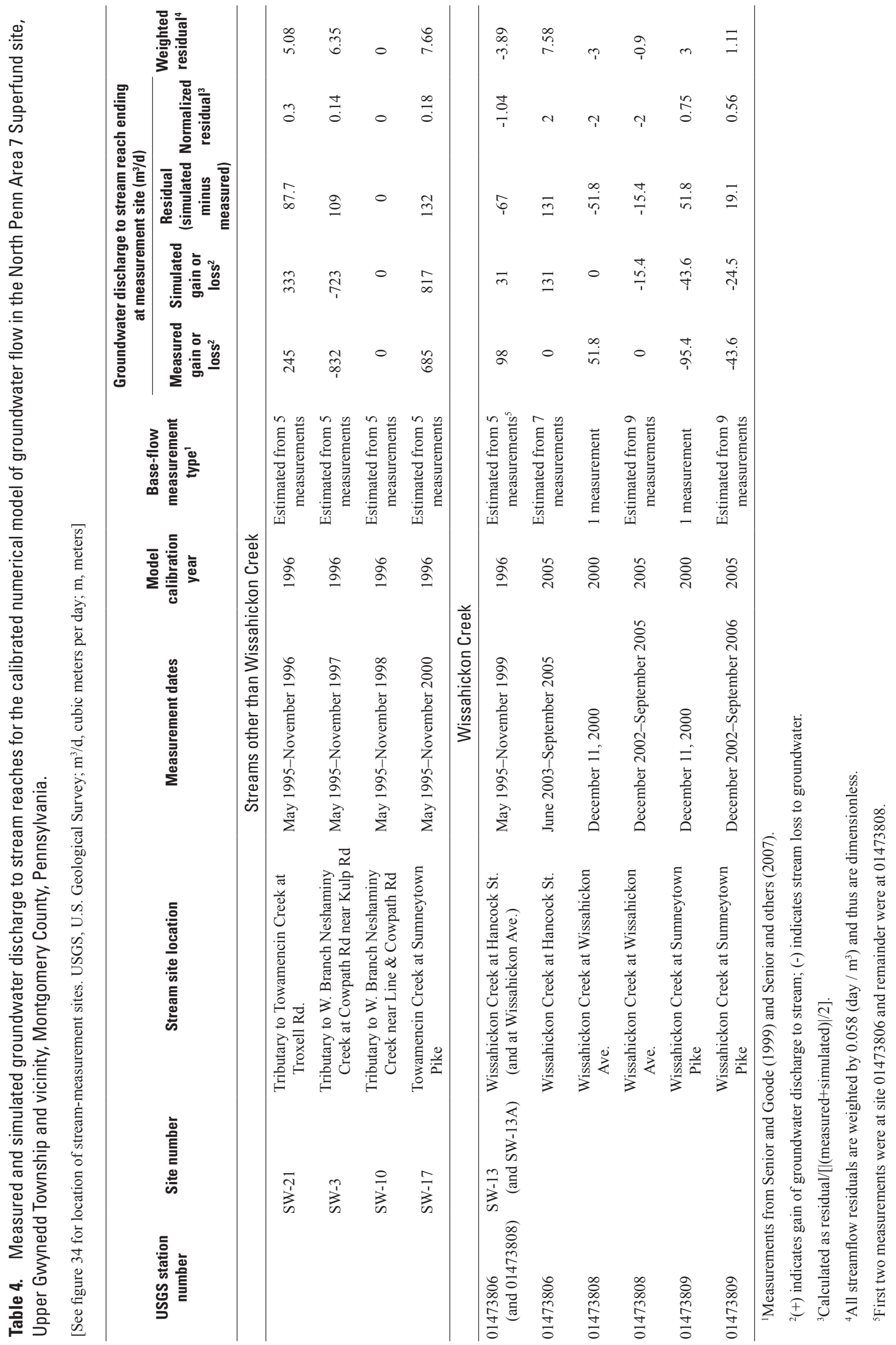


Table 5. Pumping well identification, locations and pumping rates for North Penn Area 7 Superfund site, Upper Gwynedd Township and vicinity, Montgomery County, Pennsylvania.

[USGS, U.S. Geological Survey; NGVD 29, National Geodetic Vertical Datum of 1929; m³/d, cubic meters per day; gal/min, gallons per minute]

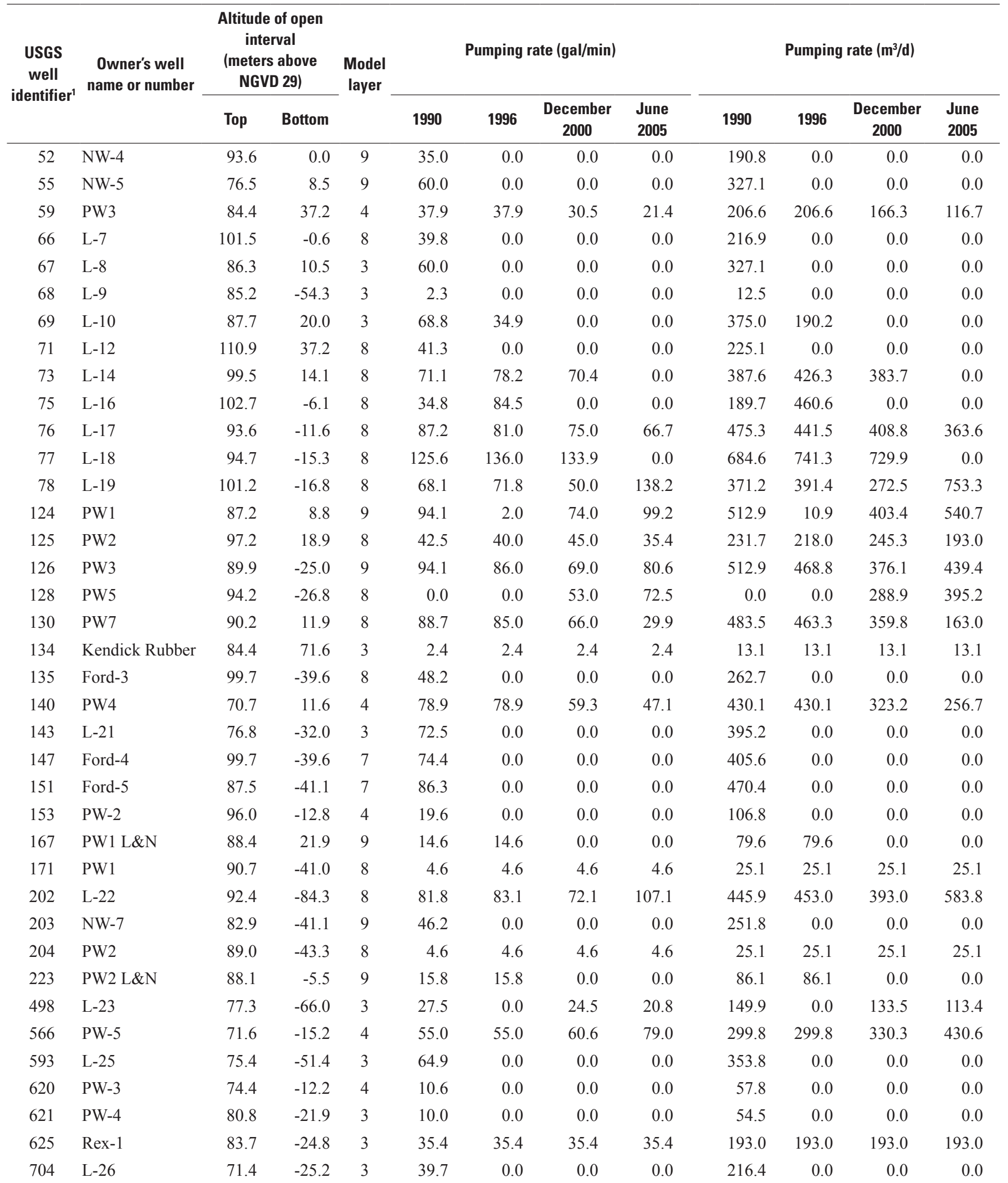


Table 5. Pumping well identification, locations and pumping rates for North Penn Area 7 Superfund site, Upper Gwynedd Township and vicinity, Montgomery County, Pennsylvania.-Continued

[USGS, U.S. Geological Survey; NGVD 29, National Geodetic Vertical Datum of 1929; m³/d, cubic meters per day; gal/min, gallons per minute]

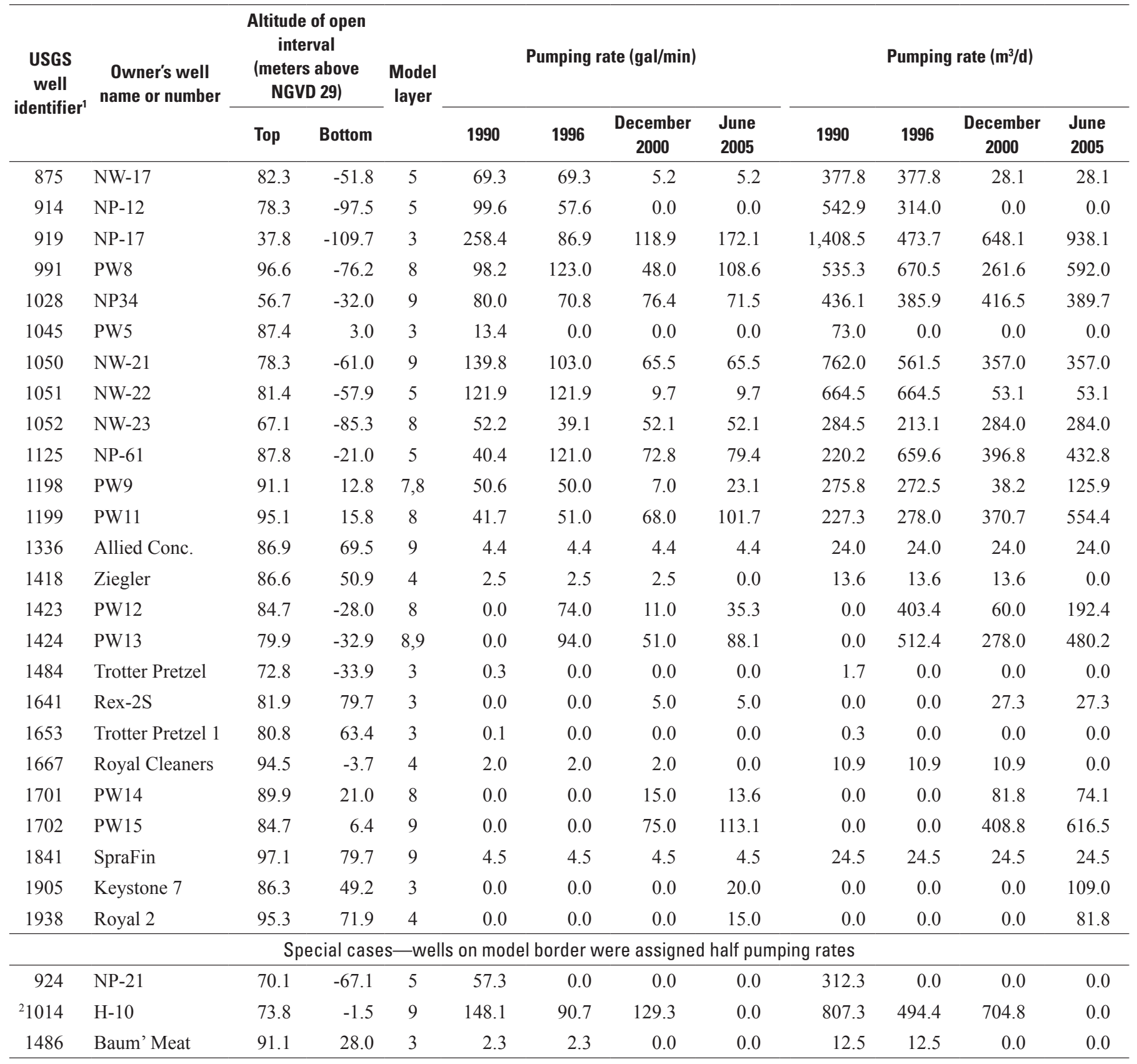

${ }^{1} \mathrm{MG}$ - prefix omitted.

${ }^{2}$ MG-1014 (H-10) was artificially moved so that the well is inside the model grid. 

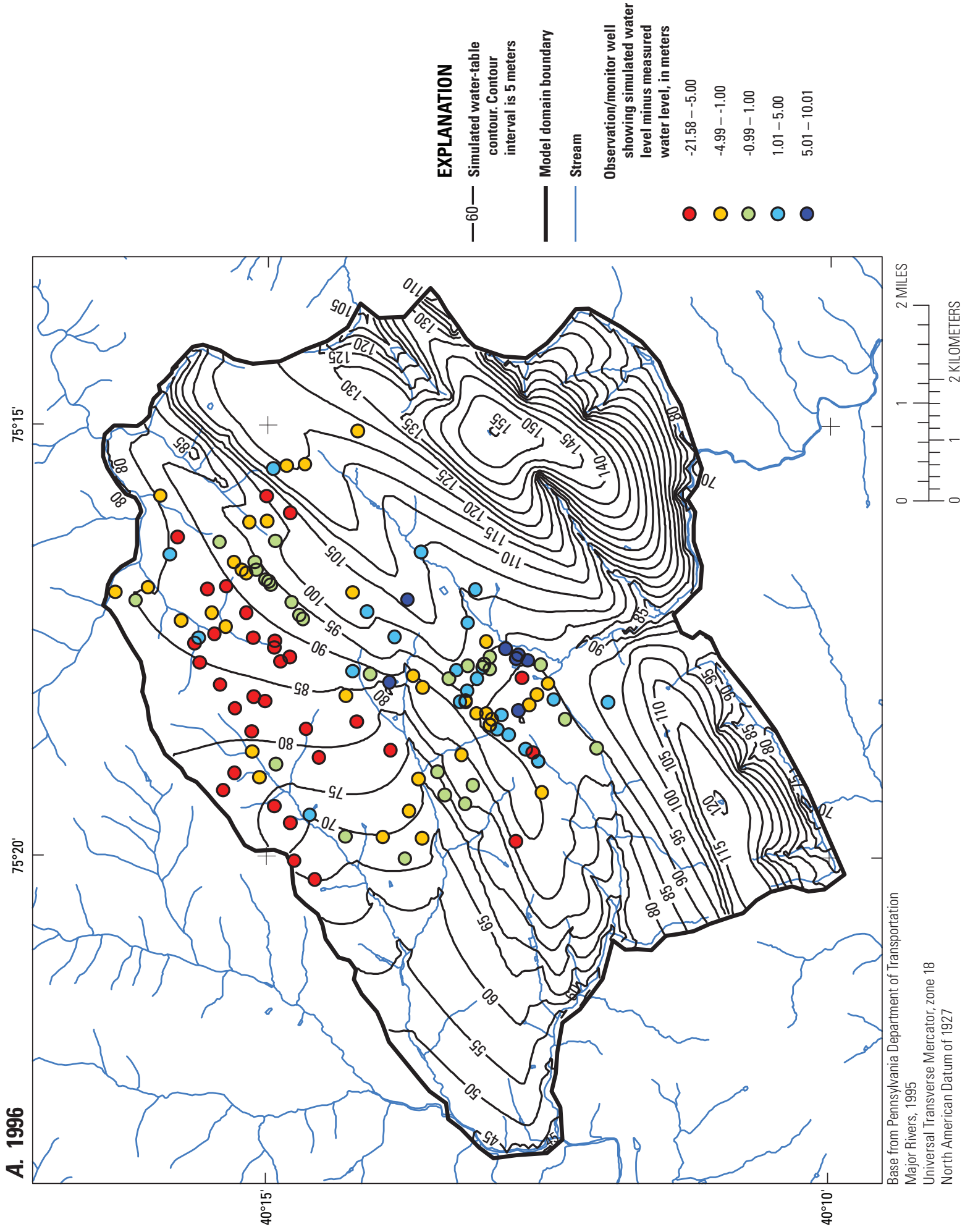

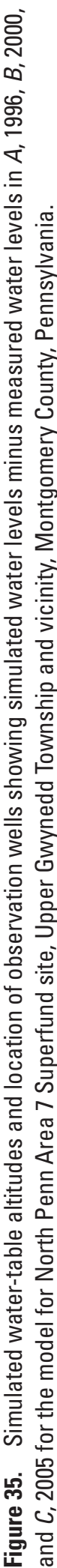



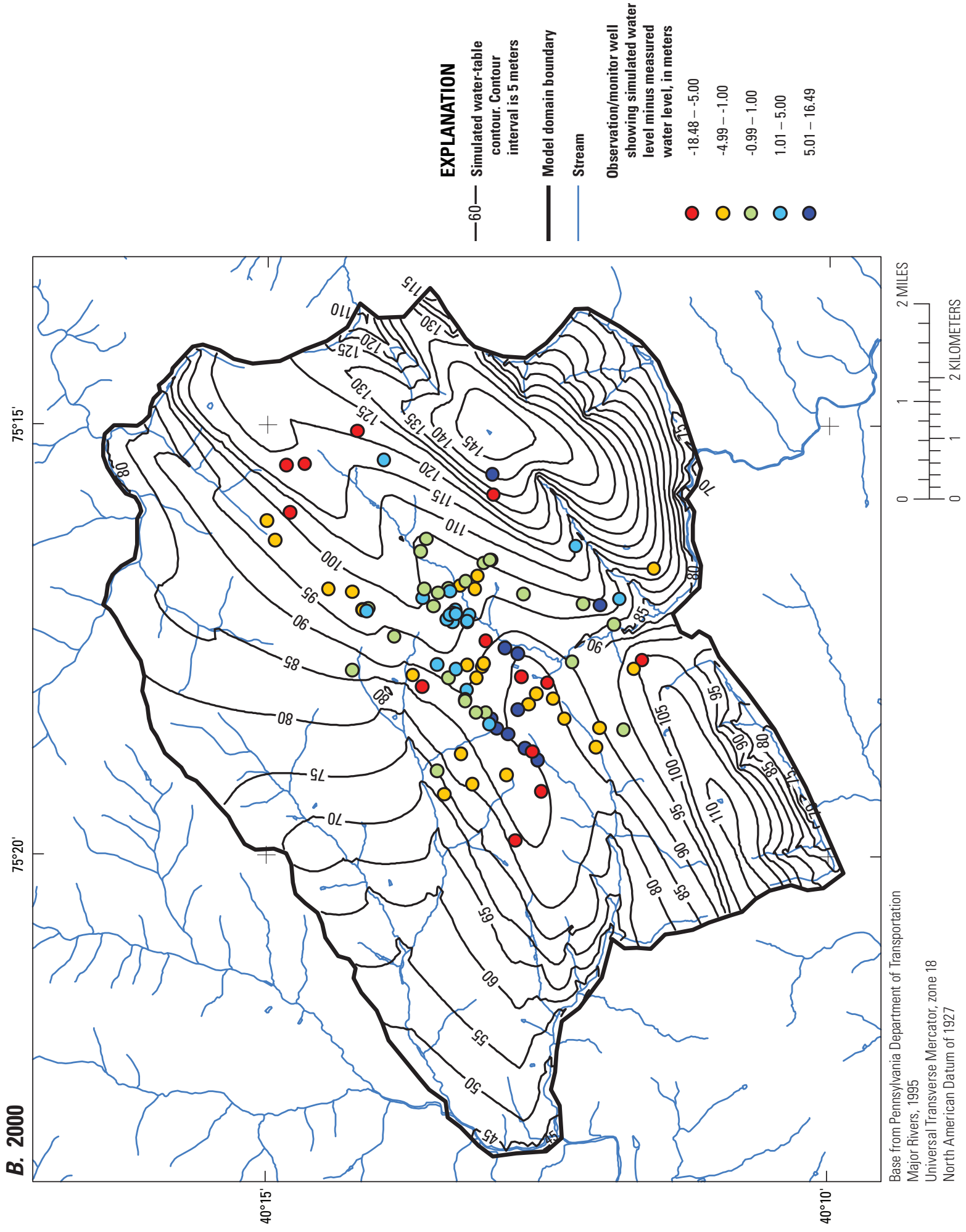

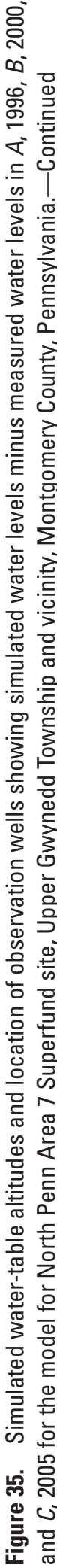



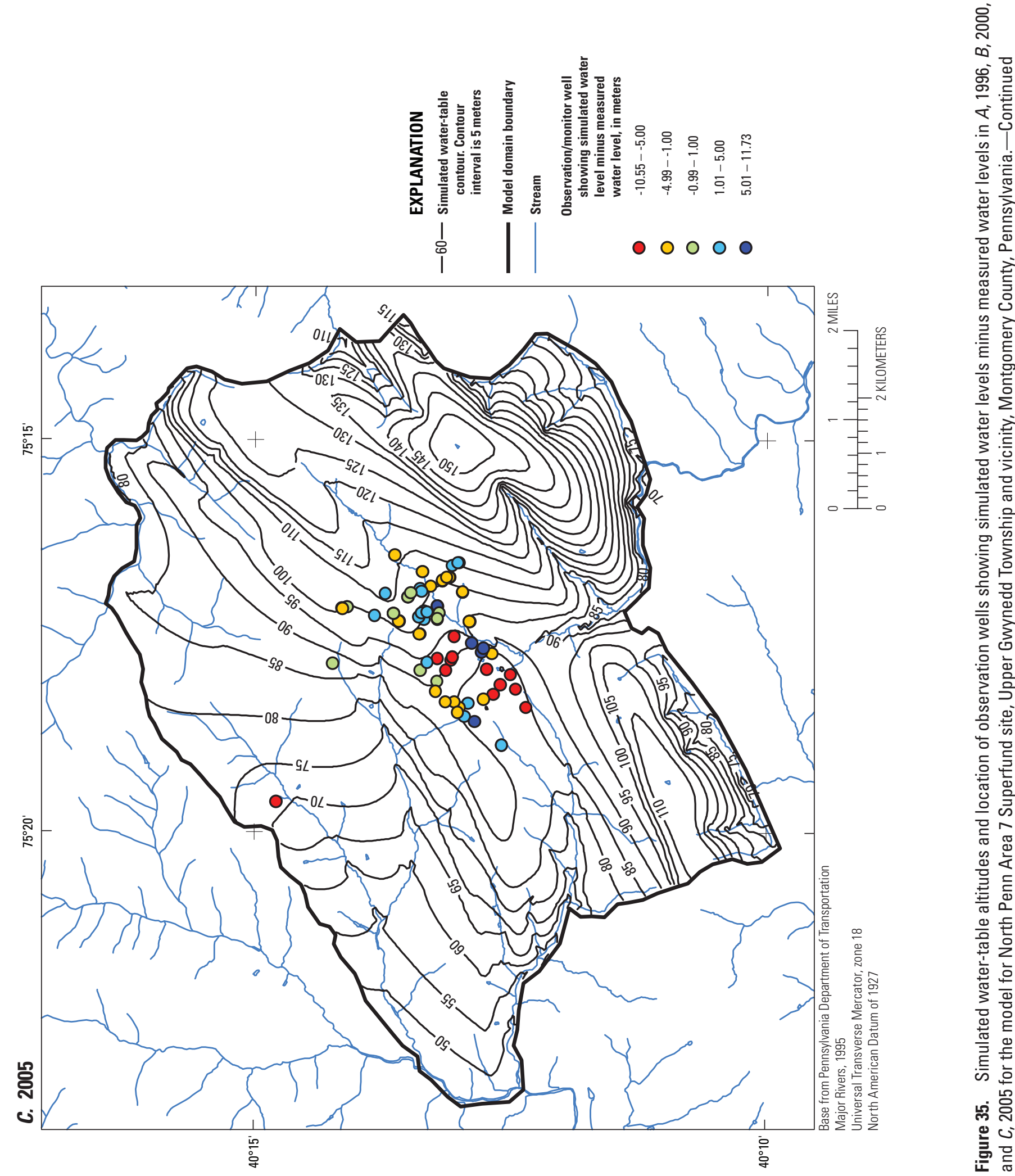
of nearby pumping (Senior, 2008, table 78), but the structure of the model placed the intermediate and deep well in the same model cell. Residuals for 2005 measurements in and near the North Penn Area 7 Superfund site range from $-10.5 \mathrm{~m}$ $(-34.4 \mathrm{ft})$ to $+11.7 \mathrm{~m}(+38.4 \mathrm{ft})$, but except for selected wells in the RI-2 and RI-9 clusters, the residuals are smaller within the boundary of North Penn Area 7, ranging from -3.9 m (-13.0 ft) to $4.1 \mathrm{~m}(+13.4 \mathrm{ft})$. Two of the three wells in the RI-2 and RI-9 clusters are affected by pumping, resulting in large vertical gradients not well simulated by the model, and residuals in these clusters range from -0.9 to $9.8 \mathrm{~m}(-3.0$ to $32 \mathrm{ft})$. The highly heterogeneous fractured-rock aquifer is simulated only approximately by this regional-scale model; however, it is judged that the model accuracy is adequate for simulation of overall regional patterns in groundwater flow and for simulation of flow paths at the regional scale.

\section{Estimated Aquifer Hydraulic Properties and Recharge Rates}

The hydraulic properties and other features of the groundwater-flow system were represented by parameters of the calibrated numerical model (table 7) that were determined by parameter estimation, a process in which the parameters are adjusted until the simulated water levels and groundwater discharge to streams reasonably match the measured water levels and groundwater discharge to streams. In this way, the numerical model mimics features of the real groundwatersystem, as characterized by the measurements, and the model parameters are considered estimates of the regional-scale hydraulic properties of the groundwater-flow system. As described above, model parameters were assigned by layers, and further grouped during calibration. Some trial parameters, such as vertical anisotropy ratios for individual layers, could not be estimated because the parameter value had no effect on the model error. Some of these parameters were assumed to be equal to other similar parameters, such as the vertical anisotropy of another layer in this example. Even with this reduced set, some parameters could not be estimated by the automatic algorithm and were manually adjusted, as discussed in previous sections.

The top two layers of the model are assumed to be isotropic in all cases because extensive fracture features are less likely to be important in highly weathered rock and saprolite and because preliminary model evaluation indicated the simulated water levels in underlying layers, where water levels have been measured, are not sensitive to the anisotropy of model layers 1 and 2. The model parameter describing the horizontal anisotropy is designated HANI for layers 3 and 11, and HANIBED for layers 4 to 10. Model layers 3 and 11 represent bulk properties of the various beds to the northwest (layer 3) and southeast (layer 11), whereas layers 4 to 10 are dipping layers representing individual mapped hydrostratigraphic units. The parameter is the hydraulic conductivity in the dip direction (northwest direction in model) divided by

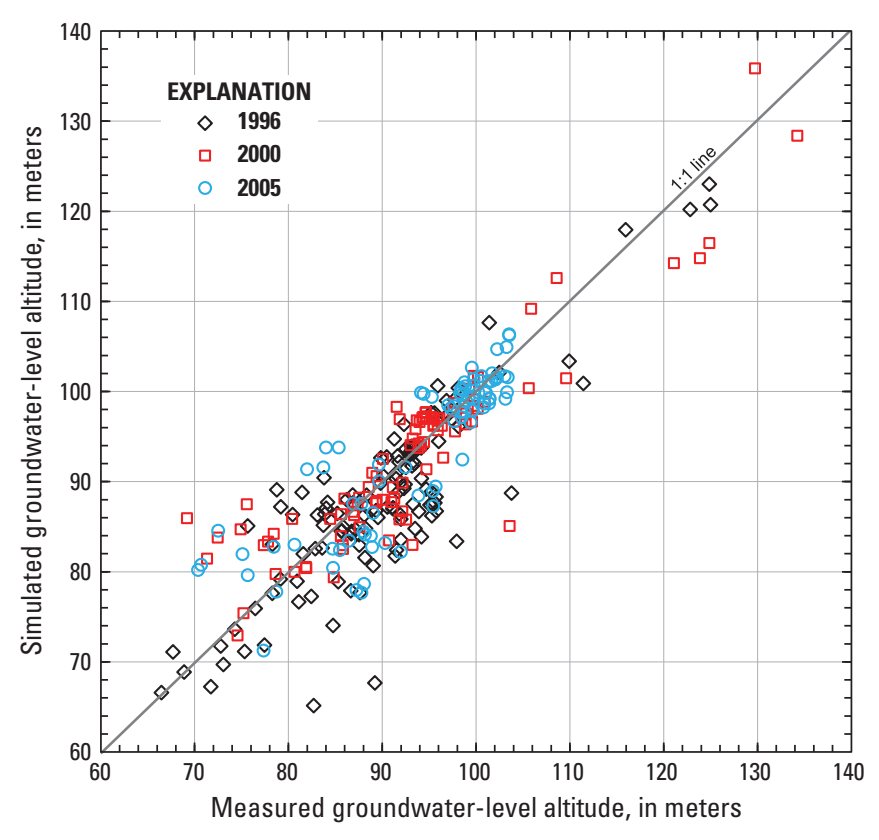

Figure 36. Relation of measured groundwater-level altitudes to groundwater-level altitudes simulated by the numerical model for North Penn Area 7 Superfund site, Upper Gwynedd Township and vicinity, Montgomery County, Pennsylvania.

the hydraulic conductivity in the strike direction (northeast direction in model) (or HANI $=\mathrm{Kdip} / \mathrm{Kstrike}$ ). In anisotropic cases, the hydraulic conductivity parameters listed in table 7 for model layers 3 to 11 are the hydraulic conductivities in the strike direction; therefore, for example, the Brunswick Group parameter KB = KBstrike, and the Lockatong Formation parameter $\mathrm{KL}=\mathrm{KL}$ strike. The hydraulic conductivity in the dip direction is the value in the strike direction multiplied by HANI.

The vertical anisotropy is parameterized in a similar, but different, manner in MODFLOW-2000. The vertical anisotropy parameter, designated VANI, is the ratio of the vertical hydraulic conductivity to the hydraulic conductivity in the strike direction; VANI = Kstrike/Kvertical. Thus, to compute the vertical hydraulic conductivity, the hydraulic conductivity in the strike direction is divided by the ratio VANI.

Other model parameters include the vertical hydraulic conductivity of streambeds, STR, which controls the conductance between layer 1 of the model and the stream. The simplified approach here is to assume that all streams have uniform width ( $3 \mathrm{~m})$ and uniform streambed thickness $(2 \mathrm{~m})$ and that the hydraulic conductivity of the streambed is also uniform. Another model parameter estimated by calibration is the uniform recharge rate, designated RECH, which is specified separately for the three different calibration time periods (table 7).

The optimum parameter values and approximate individual 95-percent confidence intervals are shown in table 7. 


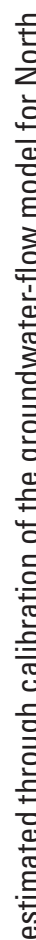
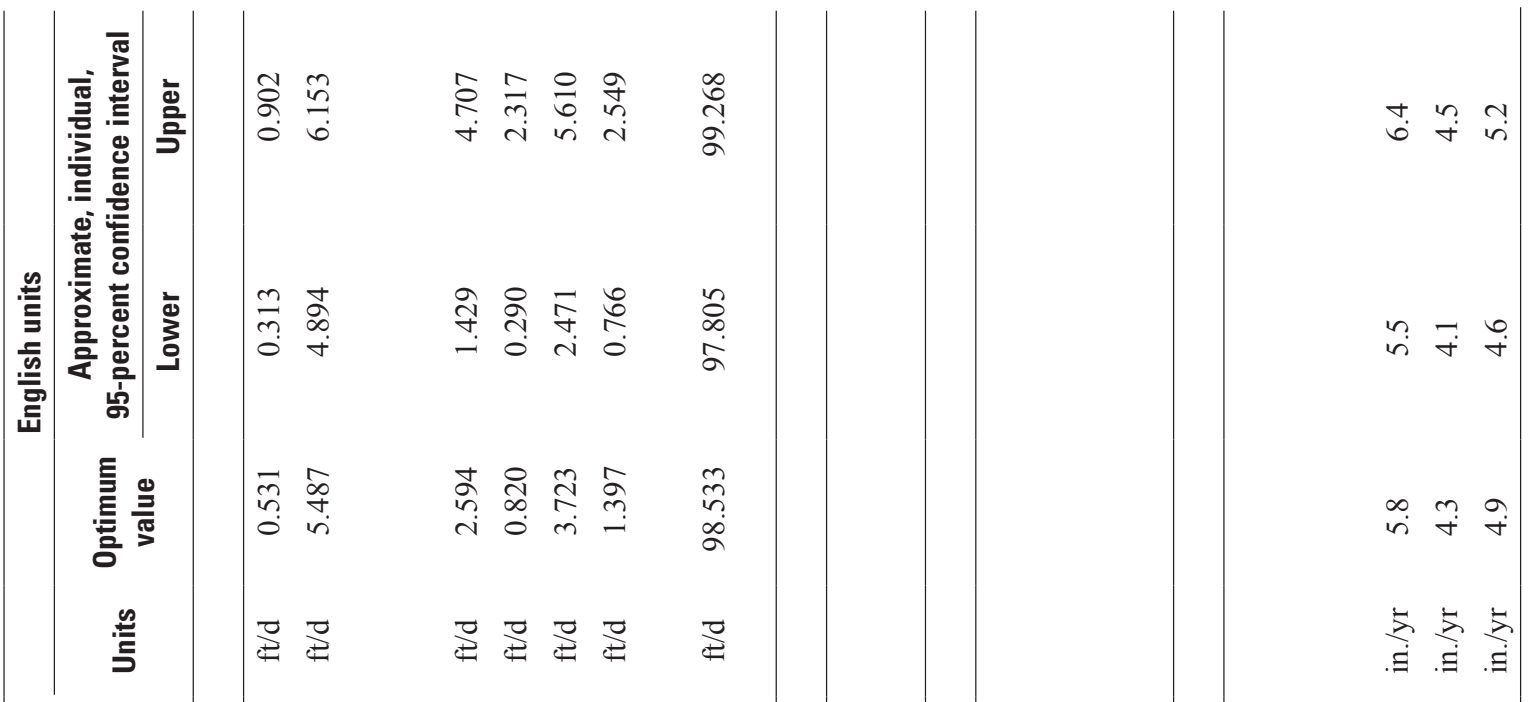

는

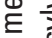

范

흥

¿

궁

$\frac{3}{\pi}$

离

d

这

등

능 음

을

일

亩要

元

긍므

. ㅡㅡ

ब

范㐫品

등 음

흠

更 5

宛

空

至

范总

ヘ் 选

ब㐫 ह

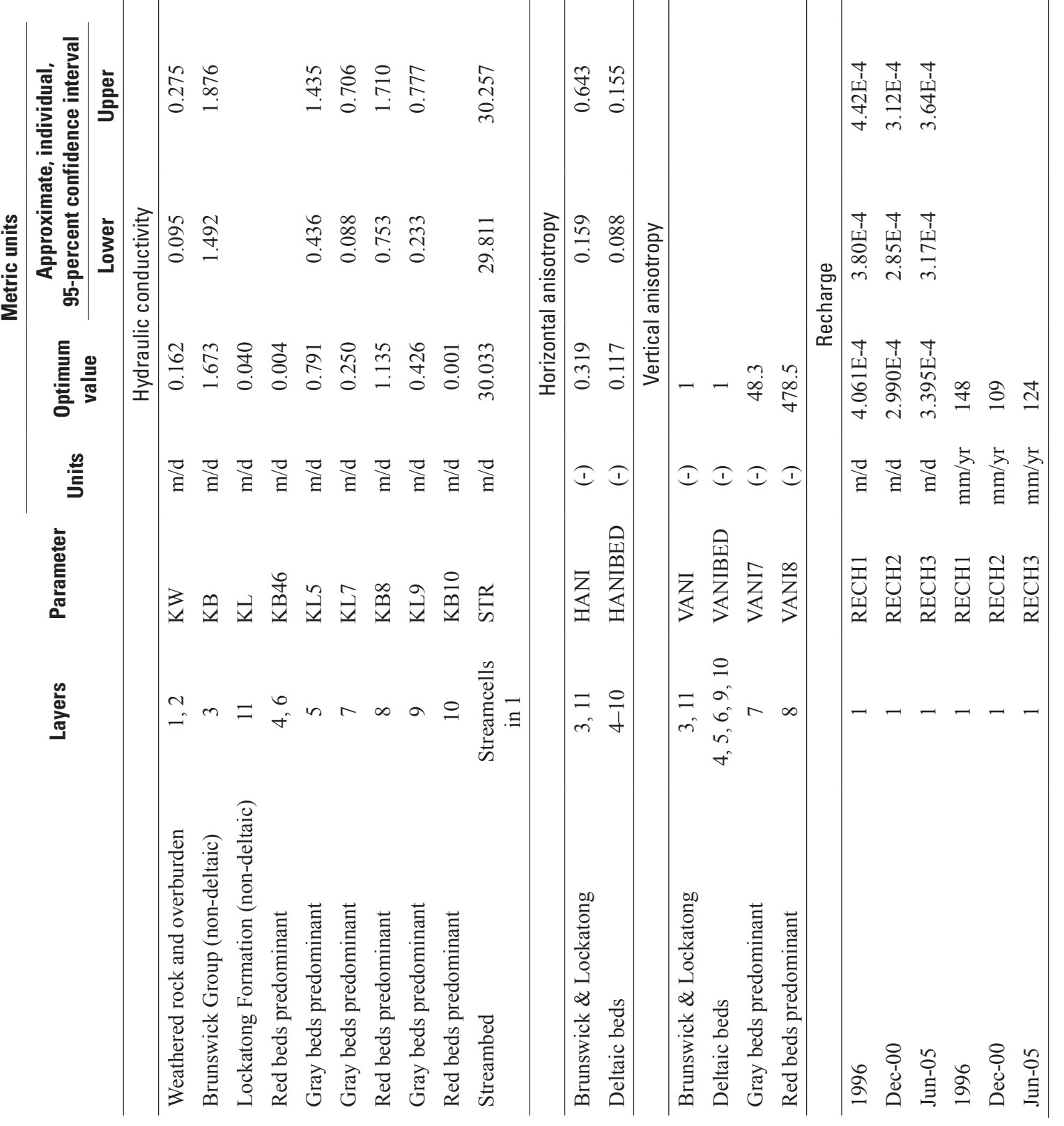


All but the top two model layers representing weathered rock/ saprolite are anisotropic with respect to subhorizontal hydraulic conductivity. The optimum value for hydraulic conductivity listed in table 7 for model layers $3-10$, representing dipping bedrock units, is subhorizontal and in the strike direction. In the set of optimum parameters, the ratio of minimum (dip direction) to maximum (strike direction) subhorizontal hydraulic conductivity ranges from $1 / 3.1$ to $1 / 8.6$ (horizontal anisotropy of 0.319 to 0.117 ). The ratio of vertical to horizontal hydraulic conductivity ranges from 1/1 (manually set during calibration for some model layers) to the optimized value of 1/478 (table 7).

The optimum parameter values yield the minimum model error for the model structure, boundary conditions, and observations used. The approximate confidence intervals are estimated from a linear statistical model with the calibrated model and assumed error variances of the observations (Hill and Tiedeman, 2007). Confidence intervals are shown only for parameters that are included in the final calibration. Model adjustments focused on parameters that, when changed, caused the greatest proportional change in simulated water levels and flow, which are indicated by their composite scaled sensitivities (fig. 37). The composite scaled sensitivity is the rate of change in the parameter-estimation optimization objective function for incremental changes in the parameter value, normalized by the optimum parameter value. Thus, the overall model error changes the most for (proportional) changes in parameters with the highest composite scaled sensitivities (Hill and others, 2000; Hill and Tiedeman, 2007). Changes to the values of parameters that have low composite scaled sensitivity will cause small changes in the model error. Compared to other parameters, the vertical hydraulic conductivity model parameters are less constrained by the measured water levels, which are relatively well distributed in horizontal space but less well distributed in vertical space and thus, provide less information about vertical head gradients to constrain the model than they do about horizontal gradients. Values for which confidence intervals are not shown in table 7 are to be considered more uncertain. During calibration, the optimization process tended to yield values for vertical anisotropy (VANI) that were less than 1 for some beds; however, values of VANI less than 1 are not consistent with the low hydraulic connections across beds observed during local-scale packer tests. The model, as structured, was not sensitive to changes in values for the parameter VANI, and therefore, the estimated value of 1 was set for the parameter VANI for beds 3 to 6 and 9 to 11 (table 7) to minimize model error and maintain some consistency with observed hydraulic properties of the aquifer.

Estimated hydraulic conductivity is comparable to previous estimates made using aquifer-test results and regional flow models. Senior and Goode (1999) estimated hydraulic conductivities of the weathered zone $(0.05 \mathrm{~m} / \mathrm{d}$ or $0.16 \mathrm{ft} / \mathrm{d})$, Lockatong Formation $(0.34 \mathrm{~m} / \mathrm{d}$ or $1.1 \mathrm{ft} / \mathrm{d}$ in strike), and the Brunswick Group ( $1.6 \mathrm{~m} / \mathrm{d}$ or $5.2 \mathrm{ft} / \mathrm{d}$ in strike) by calibration of a steady-state regional-scale model that included the current model area west of Wissahickon Creek using water

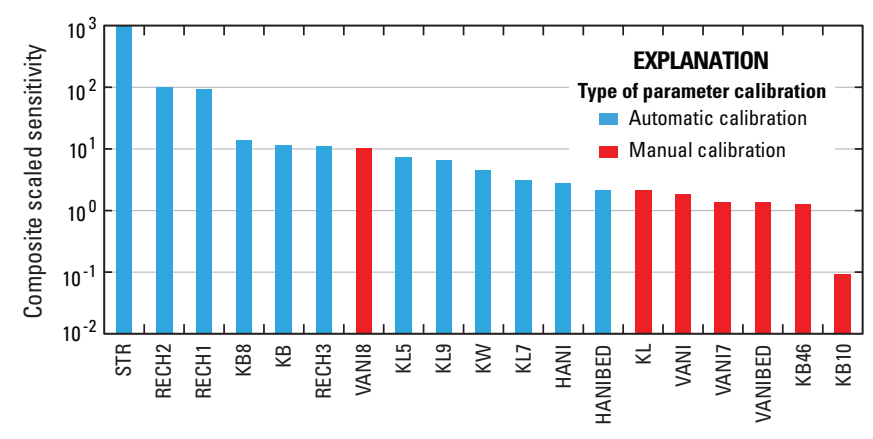

Model parameter

Figure 37. Sensitivity of model calibration to model parameters for groundwater-flow simulation of North Penn Area 7 Superfund site and vicinity, Upper Gwynedd Township and vicinity, Montgomery County, Pennsylvania. (Model parameters are described in table 7.)

levels during 1996. The optimum hydraulic conductivity for the weathered zone $(\mathrm{KW})$ is $0.16 \mathrm{~m} / \mathrm{d}(0.53 \mathrm{ft} / \mathrm{d})$, about 3 times higher than the results from Senior and Goode (1999). The optimum hydraulic conductivities for the (non-deltaic) Lockatong Formation (KL) and Brunswick Group (KB) for the present study are 0.040 and $1.67 \mathrm{~m} / \mathrm{d}(0.13$ and $5.5 \mathrm{ft} / \mathrm{d})$ in strike, respectively. For the present study, the area for which the bulk Lockatong Formation hydraulic conductivity (KL) was estimated is to the south and east of the area considered by Senior and Goode (1999) and is an area for which few water-level measurements are available. The predominantly gray beds farthest north in the present model have an optimum hydraulic conductivity (KL5) of $0.79 \mathrm{~m} / \mathrm{d}(2.6 \mathrm{ft} / \mathrm{d})$ in strike, which is slightly larger than the Lockatong Formation value estimated by Senior and Goode (1999) for rocks in the same geographic location. Hydraulic conductivities estimated using the numerical groundwater-flow model are within the range of those estimated from results of the packer tests for isolated aquifer intervals at North Penn Area 7 (Senior and others, 2008). Estimates of bulk hydraulic conductivties from packer tests calculated by dividing the total transmissivity of waterbearing zones by the total open interval of the geologic unit intersected by a borehole ranged from about 0.03 to $8.0 \mathrm{~m} / \mathrm{d}$ $(0.1$ to $26.4 \mathrm{ft} / \mathrm{d})$. Mean and median values of hydraulic conductivity for discrete aquifer intervals determined in packer tests of individual isolated zones in geologic units ranged from 1.7 to $5.6 \mathrm{~m} / \mathrm{d}(5.7$ to $18.4 \mathrm{ft} / \mathrm{d})$ and 0.9 to $1.6 \mathrm{~m} / \mathrm{d}(3.0$ to $5.1 \mathrm{ft} / \mathrm{d}$ ), respectively (fig. 13B). However, hydraulic conductivities estimated from local-scale packer tests do not appear to differ as much by geologic unit as those regional values estimated from the numerical groundwater-flow model.

Recharge rates estimated for the three simulation periods range from 109 to $148 \mathrm{~mm} / \mathrm{yr}$ ( 4.3 to $5.9 \mathrm{in} / \mathrm{yr}$ ) in 2000 and 1996 , respectively (table 7). The higher recharge values correspond to general features of the water levels in the study area: 
compared to the long-term average, water levels were similar or slightly higher in 1996 and slightly lower in December 2000 and June 2005 (fig. 19). The assumption of steady-state flow also has some effect on the estimated recharge values (Halford, 1999). The natural flow system is not at steady state for any of the time periods because of variations in time of recharge, pumping rates, and evapotranspiration. Halford (1999) found that the long-term average recharge rate was bracketed by "effective" recharge rates determined from the calibration of steady-state flow models using synoptic water levels and streamflow. In the present case, the variability of the effective recharge rate is enhanced by the low storage of the fractured-rock aquifer system. The range of recharge rates estimated in this study is similar to but about 25 percent smaller than the value of $208 \mathrm{~mm} / \mathrm{yr}$ ( $8.2 \mathrm{in} / \mathrm{yr}$ ) estimated from a different steady-state regional-flow model calibration for 1996 conditions (Senior and Goode, 1999) for a model area that included a portion of current model area west of Wissahickon Creek (see North Penn Area 6 model boundary, fig. 3). The lower value identified here may reflect that the geology underlying the current model is less dominated by the Brunswick Group and more affected by properties of the Lockatong Formation. The Lockatong Formation generally has lower permeability and, hence, may have less recharge. A single value of recharge is assumed to be representative of the entire model area for this study. Recharge rates may be estimated from, and compared to, stream base flow. White and Sloto (1990) used 1959 to 1972 streamflow records for two streams overlying Triassic sedimentary rocks in southeastern Pennsylvania and estimated average annual base flows of 148 and $201 \mathrm{~mm} / \mathrm{yr}$ (5.8 and $7.9 \mathrm{in} / \mathrm{yr}$ ).

The water budgets are different for each calibration period of the North Penn Area 7 model (table 8). Withdrawals from and recharge to the entire modeled area vary similarly, with highest rates in 1996 and lowest rates in 2000. Local withdrawals in the immediate vicinity of North Penn Area 7 (area shown by dashed boundary in figure 30) change in a similar manner.

\section{Regional Groundwater-Flow Paths}

The groundwater-flow model can be used to evaluate groundwater-flow paths under different hydrologic conditions and recharge/discharge relations. Groundwater-flow paths were simulated under conditions representative of different periods when industries using water or those identified as probable contaminant source areas were and (or) still are active in the vicinity of North Penn Area 7. The changes in hydrologic conditions considered in this report are (1) changes in pumping rates at wells and (2) changes in recharge rates, during calibration periods. For hydrologic conditions in 1990 , the average of the recharge values determined for the three calibration periods (1996, 2000, and 2005), $128 \mathrm{~mm} / \mathrm{yr}$ (5.0 in./yr), is used.
Table 8. Simulated water budgets for calibration periods 1996, 2000, and 2005 for model area and North Penn Area 7 Superfund site, Upper Gwynedd Township and vicinity, Montgomery County, Pennsylvania. Area for water-budget calculation delineated by North Penn Area 7 boundary as shown in figure 30 .

[ $\mathrm{m}^{3} / \mathrm{d}$, cubic meters per day]

\begin{tabular}{|c|c|c|c|c|}
\hline & \multirow{2}{*}{ Units } & \multicolumn{3}{|c|}{ Simulation period } \\
\hline & & 1996 & 2000 & 2005 \\
\hline \multicolumn{5}{|c|}{ Inflows } \\
\hline Recharge & $\mathrm{m}^{3} / \mathrm{d}$ & 41,642 & 30,256 & 34,508 \\
\hline Stream loss & $\mathrm{m}^{3} / \mathrm{d}$ & 2,361 & 2,904 & 2,863 \\
\hline \multicolumn{5}{|c|}{ Outflows } \\
\hline Withdrawal by pumping wells & $\mathrm{m}^{3} / \mathrm{d}$ & 11,743 & 9,207 & 9,991 \\
\hline Stream gain & $\mathrm{m}^{3} / \mathrm{d}$ & 32,259 & 23,953 & 27,380 \\
\hline \multicolumn{5}{|c|}{ Inflows } \\
\hline Recharge & $\mathrm{m}^{3} / \mathrm{d}$ & 1,178 & 856 & 976 \\
\hline Stream loss & $\mathrm{m}^{3} / \mathrm{d}$ & 26 & 44 & 101 \\
\hline Ground-water inflow & $\mathrm{m}^{3} / \mathrm{d}$ & 1,432 & 1,297 & 1,901 \\
\hline \multicolumn{5}{|c|}{ Outflows } \\
\hline Withdrawal by pumping wells & $\mathrm{m}^{3} / \mathrm{d}$ & 693 & 468 & 658 \\
\hline Stream gain & $\mathrm{m}^{3} / \mathrm{d}$ & 107 & 0 & 31 \\
\hline Ground-water outflow & $\mathrm{m}^{3} / \mathrm{d}$ & 1,836 & 1,729 & 2,289 \\
\hline
\end{tabular}

The model was used to evaluate groundwater-flow paths and areas contributing recharge to wells under several steady-state scenarios corresponding to historic and current hydrologic conditions of recharge and withdrawals in 1990, 1996, 2000, and 2005. Results from historic groundwaterflow path simulations were compared to selected measured constituent concentrations in water samples from monitor and pumped wells that may be used to infer possible contaminant migration pathways.

\section{Simulated Flow Paths, Contributing Areas, and Uncertainty}

Model simulations were conducted under steady-state conditions to estimate groundwater-flow paths and contributing areas. Steady-state simulations give results that represent the average position of groundwater-flow paths and contributing areas on the basis of the values of average groundwater recharge and withdrawals assigned to the model. Changes caused by seasonal variations in recharge or operational variability of withdrawals were not simulated. 
A probabilistic method is used to approximate uncertainty in simulated regional groundwater-flow paths because of model hydraulic-parameter uncertainty (Starn and others, 2010). Deterministic groundwater-flow paths are simulated using the optimal calibrated values for all model parameters. However, these parameters are not exactly known. The amount of uncertainty in parameter values is estimated during the automatic calibration procedure, and these results can be carried through the groundwater-flow path simulation to produce probabilistic groundwater-flow paths. A Monte Carlo procedure developed by Starn and others (2010) is used in which 1,000 realizations of different parameter sets are produced, based on the probabilistic model of the parameters and their uncertainty. This method incorporates the individual parameter uncertainty and the correlation between estimated parameters. This method was recently applied by Lindsey (2005) to a carbonate fractured-rock aquifer in Pennsylvania.

Although recharge values for 1996, 2000, and 2005, and their respective estimation variances, were estimated, these parameters are considered exactly known for the analysis here. Thus, this analysis illustrates the uncertainty that is due to selected hydraulic properties alone. A variance/covariance matrix for this uncertainty analysis is generated by the sensitivity calculations with all model parameters at their respective optimal values and with the recharge values considered known and removed from the sensitivity calculation. The resulting variance/covariance of the selected hydraulic parameters alone (table 9) is used to generate realizations of model parameters that sample the assumed lognormal parameter distribution and that preserve the estimated covariances between parameters. Many assumptions underlie the probabilistic theory for this method (Neupauer and Wilson, 2004; Starn and others, 2010), and this model may not meet all those assumptions.
For example, only 1,000 realizations were simulated for each case, and more realizations may be necessary to accurately represent low-frequency features. Nonetheless, this systematic approach does allow illustration of the effect that uncertainty in the model-selected hydraulic parameters has on model predictions, in this case regional groundwater-flow paths (Starn and others, 2010).

Groundwater-flow paths are presented on areal maps showing both deterministic and probabilistic results. The deterministic results are obtained by simulating groundwaterflow paths using the optimal parameter values identified during calibration. Deterministic groundwater-flow paths from probable contaminant sources in North Penn Area 7 are shown as gray dashed lines (for example, see figure 38 farther on in this report). Contributing areas for the pumped production well MG-202 (L-22) (fig. 4) are shown as black dots indicating model cells from which recharge flows to the pumped well (for example, see figure 39 farther on in this report).

For probabilistic results, model cell color indicates frequency, which is expressed as a fraction ranging from 0 to 1.0. For contributing areas of water for pumped well MG-202 (L-22), the colors correspond to the frequency of simulations for which recharge from the indicated model cell at the top of the saturated zone flowed to the pumped well. For example, if 800 of the 1,000 simulations resulted in flow to the pumped well from a particular cell, then that cell would be the color corresponding to a frequency of 0.8 . For the groundwaterflow-path simulations, the color map indicates the frequency at which particles from source locations flowed through the area covered by the model cell. This result is vertically integrated in that groundwater-flow paths through the cell area are counted regardless of which vertical model layer the

Table 9. Correlation and variance/covariance matrices for generation of probabilistic parameters.

[Correlations are in shaded part of table. Both matrices are symmetric, so the upper or lower diagonal of either matrix is the transpose of the part of the matrix shown. Correlations of parameters with themselves are equal to 1.0 and are not shown. The logarithm of the parameter value is used in the regression for all parameters. These covariances and correlations are for the parameters in the regression space]

\begin{tabular}{l|ccccccccccc}
\hline Parameter & HANIBED & KB & KW & STR & KB46 & KL5 & HANI & KB8 & KL7 & KL9 \\
\hline HANIBED & $1.75 \mathrm{E}-2$ & $6.76 \mathrm{E}-4$ & $6.43 \mathrm{E}-3$ & $-9.69 \mathrm{E}-5$ & $-1.27 \mathrm{E}-2$ & $-1.14 \mathrm{E}-2$ & $1.16 \mathrm{E}-2$ & $-3.57 \mathrm{E}-3$ & $1.93 \mathrm{E}-3$ & $-5.89 \mathrm{E}-3$ \\
KB & 0.14 & $1.25 \mathrm{E}-3$ & $-4.80 \mathrm{E}-3$ & $-4.52 \mathrm{E}-5$ & $3.62 \mathrm{E}-3$ & $-2.09 \mathrm{E}-3$ & $4.02 \mathrm{E}-3$ & $-2.04 \mathrm{E}-3$ & $3.67 \mathrm{E}-3$ & $-8.39 \mathrm{E}-4$ \\
KW & 0.19 & -0.54 & $6.32 \mathrm{E}-2$ & $2.60 \mathrm{E}-4$ & $-4.88 \mathrm{E}-2$ & $-2.68 \mathrm{E}-3$ & $-1.22 \mathrm{E}-2$ & $1.37 \mathrm{E}-2$ & $-3.82 \mathrm{E}-2$ & $-4.99 \mathrm{E}-3$ \\
STR & -0.27 & -0.48 & 0.39 & $7.19 \mathrm{E}-6$ & $-4.26 \mathrm{E}-4$ & $3.78 \mathrm{E}-4$ & $-5.64 \mathrm{E}-4$ & $3.57 \mathrm{E}-4$ & $-3.16 \mathrm{E}-4$ & $2.87 \mathrm{E}-4$ \\
KB46 & -0.12 & 0.13 & -0.24 & -0.20 & $6.38 \mathrm{E}-1$ & $-1.09 \mathrm{E}-1$ & $7.11 \mathrm{E}-2$ & $7.40 \mathrm{E}-3$ & $-1.08 \mathrm{E}-1$ & $-5.31 \mathrm{E}-2$ \\
KL5 & -0.33 & -0.22 & -0.04 & 0.54 & -0.52 & $6.93 \mathrm{E}-2$ & $-4.18 \mathrm{E}-2$ & $6.20 \mathrm{E}-3$ & $-1.31 \mathrm{E}-2$ & $2.83 \mathrm{E}-2$ \\
HANI & 0.33 & 0.43 & -0.18 & -0.80 & 0.34 & -0.60 & $7.00 \mathrm{E}-2$ & $-2.35 \mathrm{E}-2$ & $7.67 \mathrm{E}-3$ & $-2.86 \mathrm{E}-2$ \\
KB8 & -0.16 & -0.34 & 0.32 & 0.78 & 0.05 & 0.14 & -0.52 & $2.90 \mathrm{E}-2$ & $-5.09 \mathrm{E}-2$ & $1.06 \mathrm{E}-2$ \\
KL7 & 0.03 & 0.20 & -0.30 & -0.23 & -0.26 & -0.10 & 0.06 & -0.59 & $2.60 \mathrm{E}-1$ & $1.05 \mathrm{E}-2$ \\
KL9 & -0.30 & -0.16 & -0.13 & 0.73 & -0.45 & 0.73 & -0.73 & 0.42 & 0.14 & $2.17 \mathrm{E}-2$ \\
\hline
\end{tabular}


groundwater-flow path occurs in. For example, if 400 of the 1,000 simulations resulted in at least one groundwater-flow path from any of the sources passing through any layer at a model cell location, then that color of the cell corresponds to a frequency of 0.4 .

In general, the probabilistic groundwater-flow-path results resemble a diffuse cloud around the deterministic groundwater-flow paths. Simulations of contributing area to a pumped well have high frequencies in the middle of the deterministic contributing area and close to the pumped well. Frequencies are lower at greater distances from the pumped well and at the edges of the contributing area. Similar features occur for groundwater-flow-path results where frequencies are high near source locations; however, the features may occur far from the source location near large pumped wells as a result of the convergence of groundwater-flow paths near the large well or well field.

In the following sections, deterministic groundwaterflow paths and contributing areas simulated using optimal model parameters are discussed for each period. Uncertainty associated with flow paths estimated using the Monte Carlo method is shown in figures with results of the deterministic simulations for each time period but is not discussed at length. In general, probabilistic groundwater-flow paths simulated using uncertain model parameters (Monte Carlo method) pass through similar, but expanded, areas around deterministic flow paths simulated using optimal model parameters.

\section{Groundwater-Flow Paths in 1990}

Groundwater withdrawals in the study area were relatively high in 1990, and more wells in the vicinity of North Penn Area 7 were pumped for industrial and public supply than in subsequent periods. Using optimal model parameters, simulated deterministic groundwater-flow paths from contaminant sources in North Penn Area 7 ultimately reach local wells at the industrial facilities, with the exception of groundwaterflow paths from the source at Leeds \& Northrup and some of the groundwater-flow paths from the source at Spra-Fin, which discharge to wells such as well MG-130 at the Merck facility immediately southwest of North Penn Area 7 (fig. 38). Probabilistic simulations also show most groundwater-flow paths extend from contaminant sources towards local pumped wells in the vicinity of North Penn Area 7. Simulated deterministic groundwater-flow paths from sources at the Zenith, Teleflex, and Ford facilities discharge to pumped wells at Ford. The frequencies of probabilistic groundwater-flow paths extending from contaminant sources to areas at and near Ford are higher than 0.75 . Simulated groundwater-flow paths from the source at Spra-Fin travel beneath the upper Wissahickon Creek and discharge to industrial wells at other properties in the vicinity of North Penn Area 7, including pumped wells at Ford and well MG-130 at Merck. Groundwater flow from the source at the Rogers facility (a named contaminant source in NPL site North Penn Area 6) is generally southwest, away from North Penn Area 7, towards pumped production wells MG-59, MG-566, and MG-140. Some probabilistic simulations result in groundwater-flow paths extending east from the Rogers facility to nearby pumped wells MG-66 and MG-71, although the frequencies are less than 0.25 .

The production well MG-202 (L-22) does not capture any groundwater-flow paths from identified contaminant sources at North Penn Area 7 in the deterministic simulation using optimal model parameters (fig. 38). For the probabilistic simulations, the frequency of groundwater-flow paths extending from contaminant sources to areas near well MG-202 ranges from 0.05 to 0.25 .

Modeled contaminant source locations do not appear likely to be in the contributing area of recharge flowing to well MG-202 under conditions in 1990 (fig. 39). The frequency of probabilistic simulations for which recharge from modeled contaminant source cells flows to MG-202 is less than 0.05 . The deterministic simulated contributing area for water pumped from MG-202 is east of the pumped well. For probabilistic simulations, the frequency of recharge flowpaths discharging to well MG-202 (L-22) decreases with distance away from the well to the east. Under simulated steadystate conditions, some water flowing to the well is recharged beyond the contributing area for nearby well MG-76 (L-17). The contributing area for well MG-76 (L-17) is surrounded by areas that contribute flow to MG-202 (L-22).

The complex shape of the contributing area to MG-202 (L-22) is caused by the juxtaposition of contributing areas of other nearby wells and the complex groundwater/surfacewater interaction in the headwaters of the Wissahickon Creek. In addition to capturing groundwater recharge through the aquifer, well MG-202 (L-22) also captures flow from the Wissahickon Creek. This flow originates as recharge to groundwater near the stream, discharges to the stream, and then returns to the aquifer near well MG-202 (L-22). Thus, both groundwater and surface water contribute flow to this well. Contaminant sources in areas that discharge to Wissahickon Creek could be sources of contamination to well MG-202 (L-22), provided that the discharge to the stream occurs upstream from the area where the stream loses water to the aquifer near well MG-202 (L-22).

Although the deterministic groundwater-flow paths indicate that a thin ring of surface area contributes recharge to the well, the probabilistic plume indicates that a much larger area could potentially contribute recharge to the well, but the frequency for any particular spot as a contaminant source is relatively low. In general, these probabilistic results do not incorporate all uncertainty in the predictive methods used for groundwater-flow simulations, but only the uncertainty associated with specific parameter values for the specific regionalscale model developed for North Penn Area 7 and described in this report. 


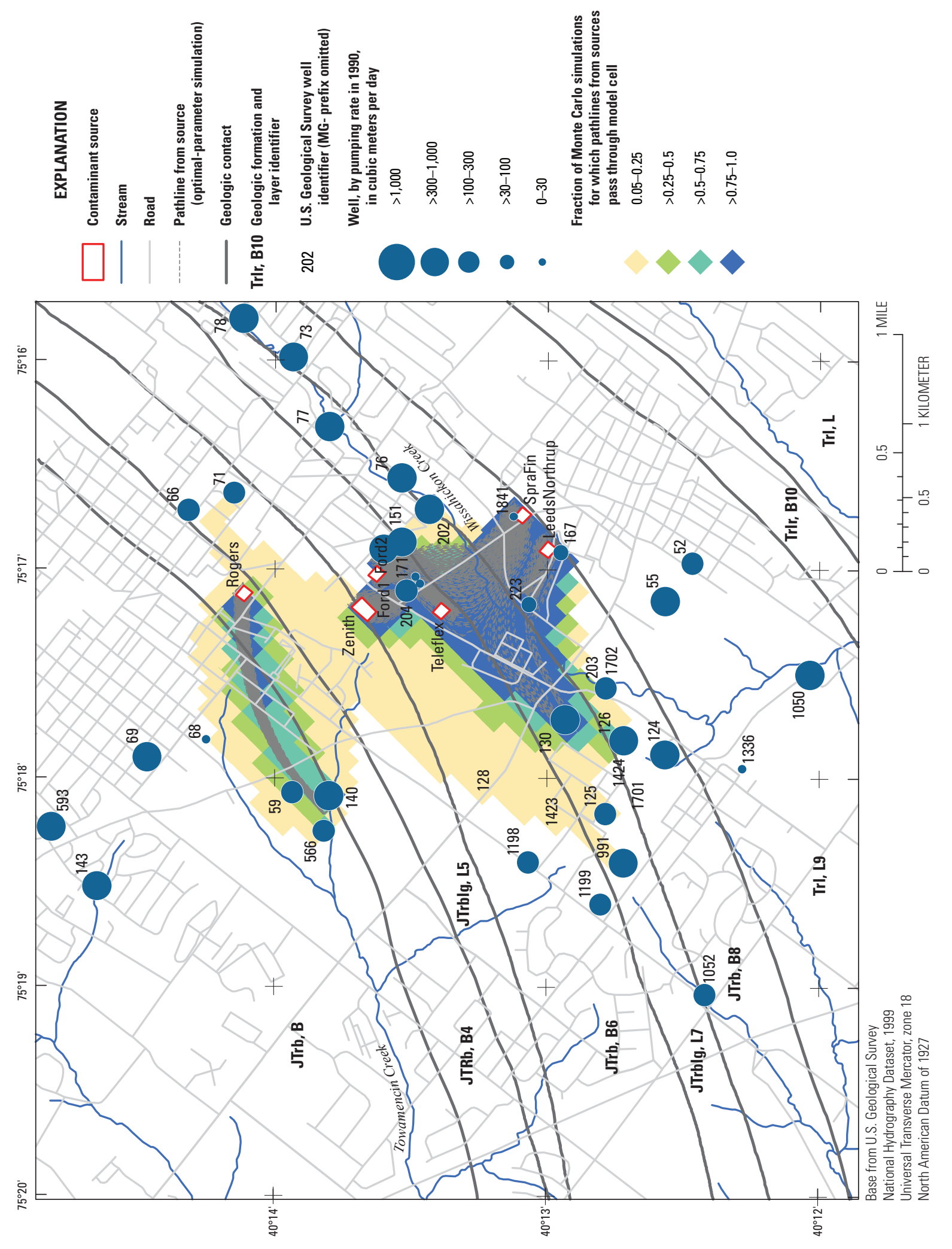

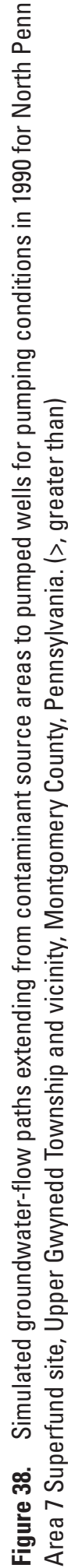




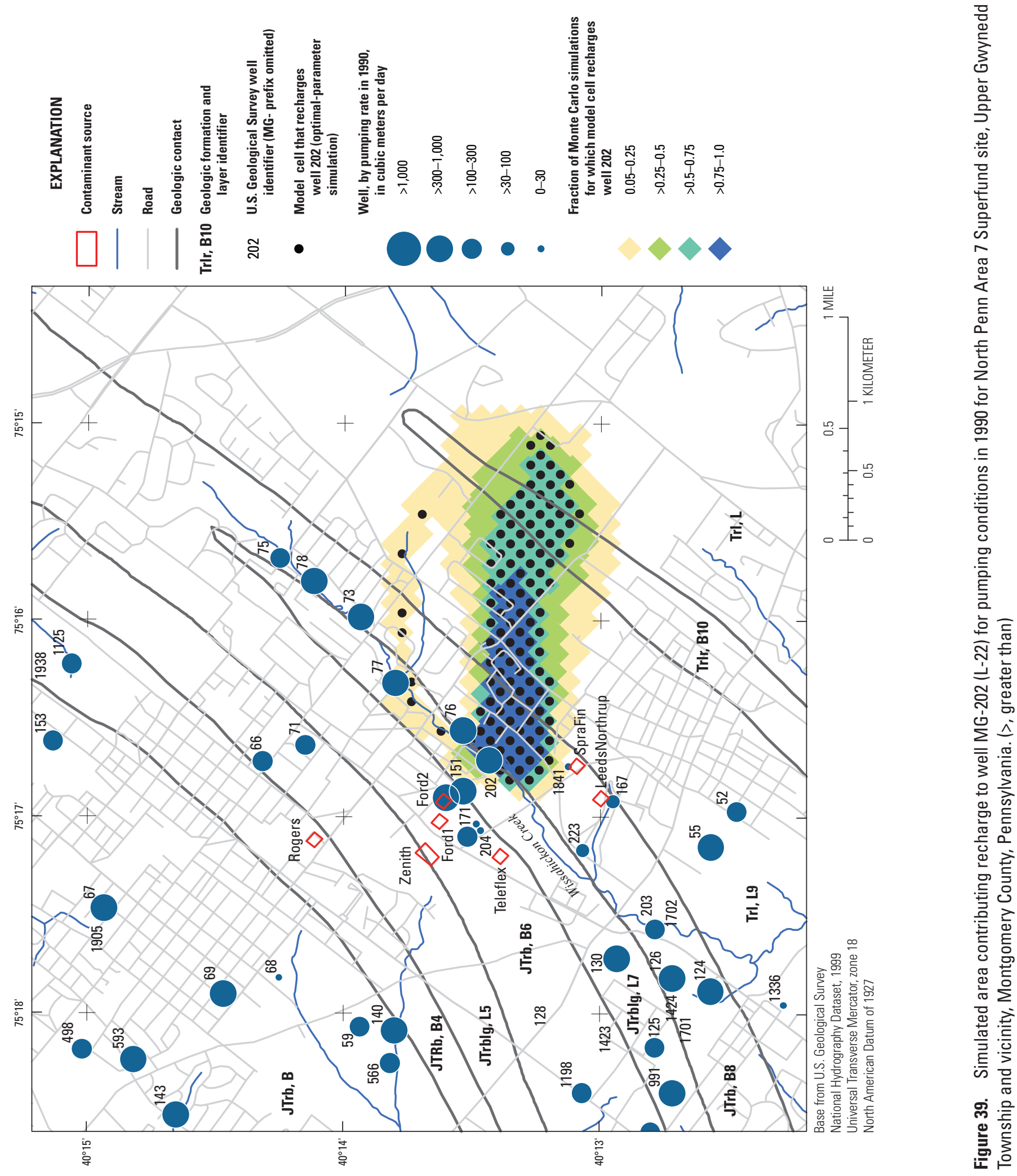




\section{Groundwater-Flow Paths in 1996}

Groundwater pumping rates in the vicinity of North Penn Area 7 in 1996 (a model calibration period) were lower than in 1990 (table 5), and fewer wells were operating. Simulated deterministic groundwater-flow paths (fig. 40) are generally longer in 1996 than in 1990, with nearly all groundwater-flow paths leaving the immediate area of the contaminant sources and discharging to pumped wells southwest and west of North Penn Area 7. Industrial wells at Ford that captured simulated groundwater-flow paths from contaminant sources in the 1990 simulation were no longer pumping in 1996. Simulated deterministic and probabilistic groundwater-flow paths extend from the contaminant source at the Zenith facility to Merck facility wells (including wells MG-1198 and MG-1199) to the southwest and to well MG-140 to the west of North Penn Area 7 (fig. 40). For probabilistic simulations, the frequencies of flow paths extending from all North Penn Area 7 contaminant-source areas to pass near or arrive at Merck wells are greater than 0.75 . The deterministic groundwater-flow paths from the Rogers facility source are similar to those in 1990. The shutdown of the two pumped wells northeast of Rogers (MG-66 and MG-71) results in very low frequency of the probabilistic groundwater-flow paths passing through the area east of Rogers (fig. 40).

Production well MG-202 (L-22) does not capture any deterministic groundwater-flow paths from identified contaminant sources in North Penn Area 7 in the 1996 simulation (fig. 40). The frequency of probabilistic simulations that indicate groundwater-flow paths extend from contaminant sources to areas near well MG-202 (L-22) is less than 0.05.

In the simulation of contributing area, modeled source locations do not appear to contribute recharge to well MG-202 (L-22) under conditions in 1996 (fig. 41). The frequency of probabilistic simulations for which recharge from identified contaminant sources in North Penn Area 7 flows to MG-202 (L-22) is less than 0.05 . The deterministic contributing area simulated using optimal model parameters for withdrawals from well MG-202 (L-22) is located east of the well; a thin and discontinuous contributing area extends to the northeast. The probabilistic contributing area also extends to the northeast, but the frequencies are low, less than 0.25 at any particular location. As in the 1990 simulation, the probabilistic contributing area to MG-202 has a complex shape caused by nearby pumped wells and surface-water/groundwater interaction in the headwaters of the Wissahickon Creek. Under simulated steady-state conditions, some water flowing to well MG-202 (L-22) is recharged beyond the contributing areas for nearby wells in the Wissahickon well field [MG-76 (L-17), MG-77 (L-18), MG-73 (L-14), MG-78 (L-19), and MG-75 (L-16)]. The contributing areas for other wells in the well field are surrounded by areas that contribute flow to well MG-202 (L-22).

\section{Groundwater-Flow Paths in 2000}

Groundwater pumping rates in the study area were relatively low (table 5), and fewer wells were pumping in 2000 (a calibration period) than in the other time periods. Simulated deterministic and probabilistic groundwater-flow paths from contaminant sources in North Penn Area 7 (fig. 42) are similar to, but slightly different than, those in 1996. For 2000, simulated groundwater-flow paths from all contaminant sources converge towards nearby pumped wells west and southwest of North Penn Area 7. More of the deterministic groundwaterflow paths from the source at the Zenith facility discharge to the area that contributes to Merck wells (MG-128, MG-1198, and MG-1199) and fewer discharge to the areas contributing to production well MG-140 in the 2000 simulation (fig. 42) than in the 1996 simulation (fig. 40). The frequencies for probabilistic flow paths from all North Penn Area 7 contaminant sources to pass near or arrive at Merck wells are higher than 0.75 .

As in the 1990 and 1996 simulations, production well MG-202 (L-22) does not capture any deterministic groundwater-flow paths from identified contaminant sources in North Penn Area 7 (fig. 42). The frequency of probabilistic simulations that indicates groundwater-flow paths extend from North Penn Area 7 contaminant sources to areas near well MG-202 is less than 0.05 .

In the simulation of contributing area, modeled contaminant source locations do not appear likely to contribute recharge to well MG-202 (L-22) under conditions in 2000 (fig. 43). The frequency of probabilistic simulations for which recharge from identified contamination sources in North Penn Area 7 flows to MG-202 (L-22) is less than 0.05. The deterministic contributing area for water pumped from MG-202 (L-22) is east of the well; a thin and discontinuous contributing area extends to the northeast. The probabilistic contributing area also extends to the northeast, but the frequencies are low, less than 0.25 at any particular location. As in the 1990 and 1996 simulations, the contributing area to MG-202 (L-22) has a complex shape caused by nearby pumped wells and groundwater/surface-water interaction in the headwaters of the Wissahickon Creek. Under simulated steady-state conditions, some water flowing to well MG-202 (L-22) is recharged beyond the contributing areas for nearby wells in the Wissahickon well field. [MG-76 (L-17), MG-77 (L-18), MG-73 (1-14), and MG-78 (L-19) were pumping, but MG-75 (L-16) was not pumping in December 2000.] The contributing areas for other wells in the well field are surrounded by areas that contribute flow to well MG-202 (L-22). 


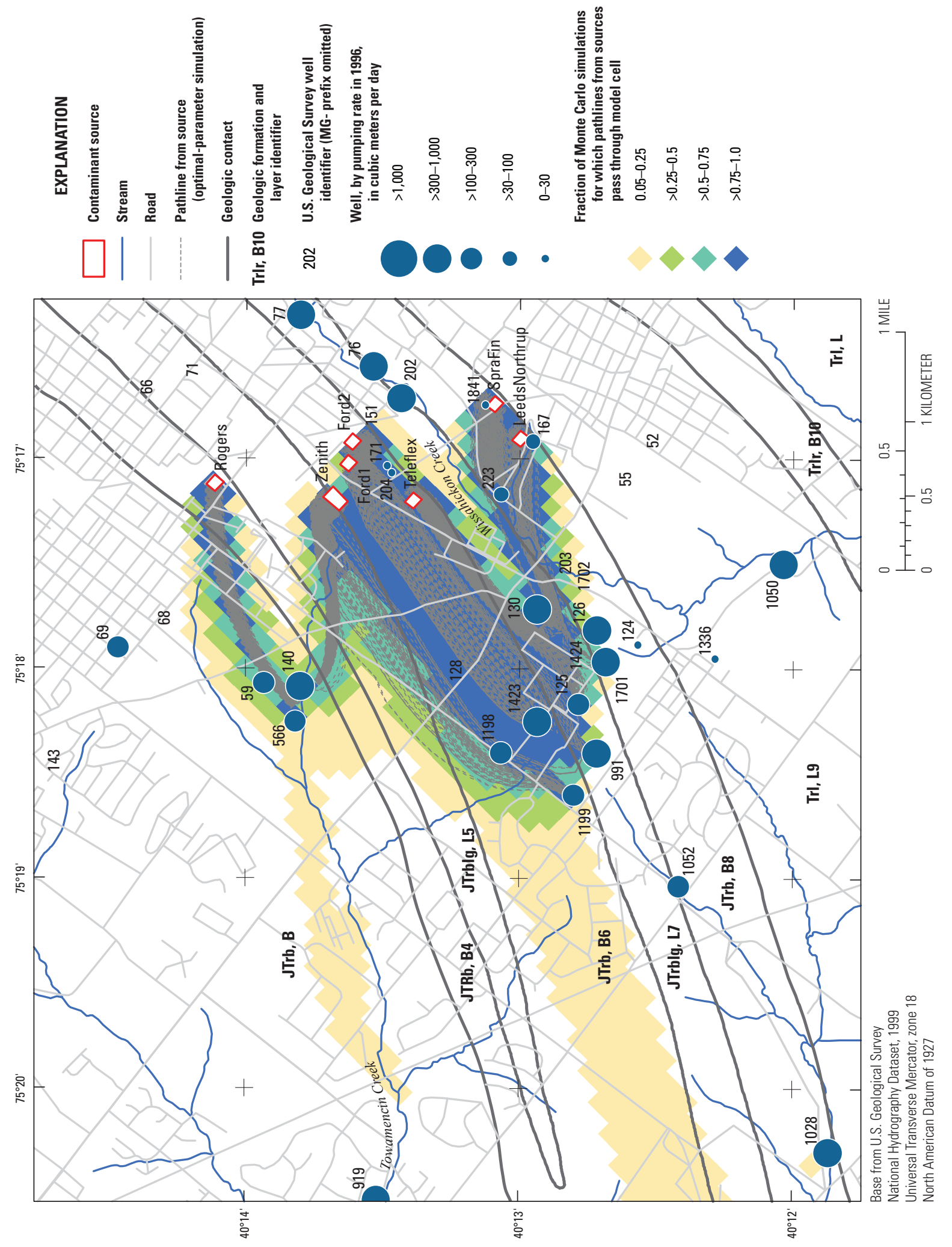

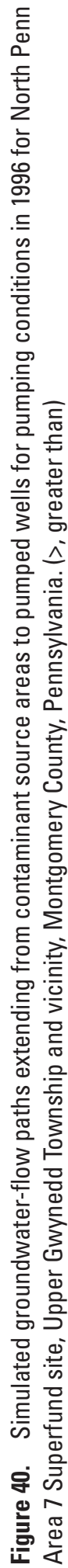



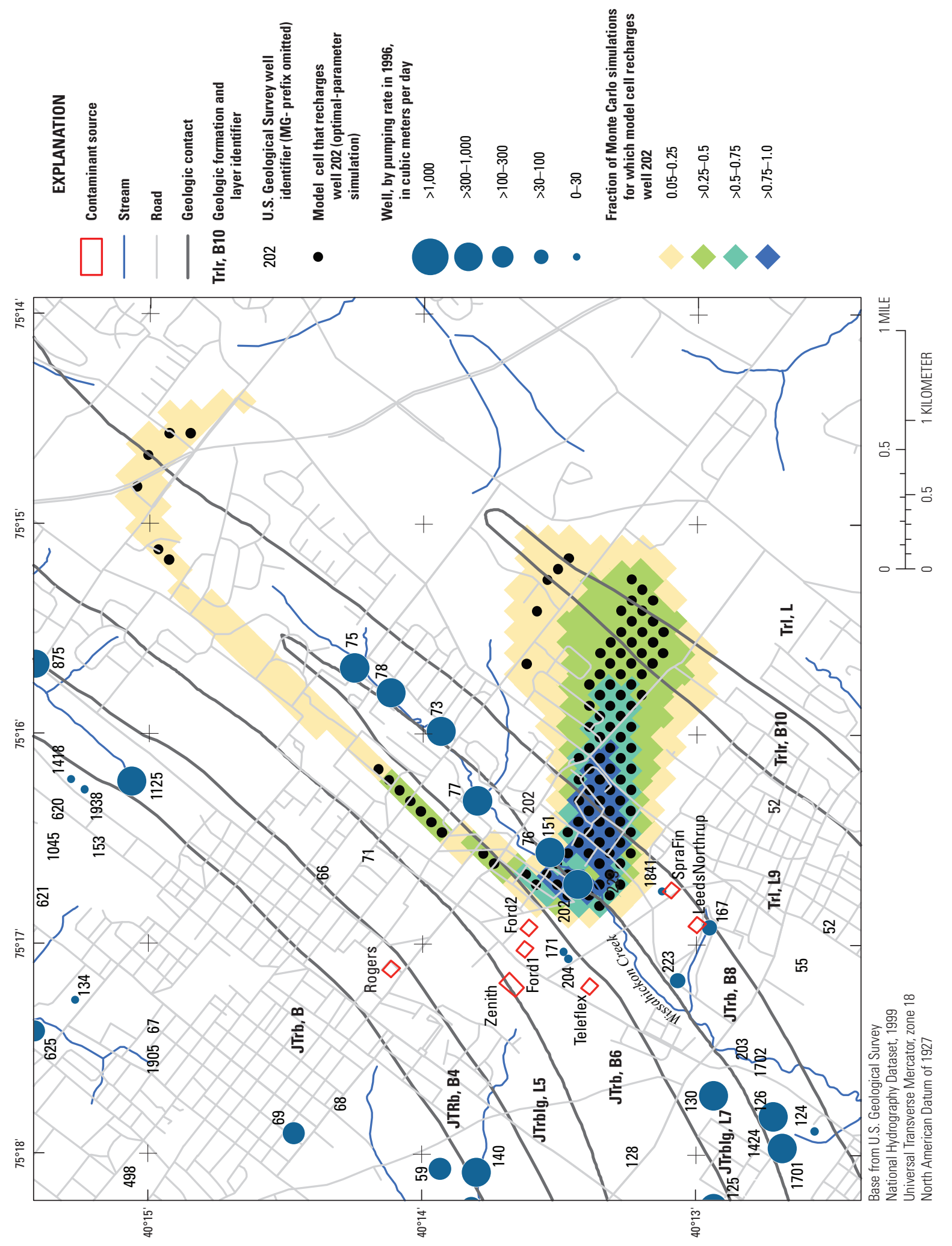

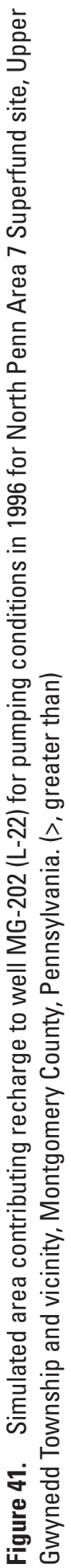




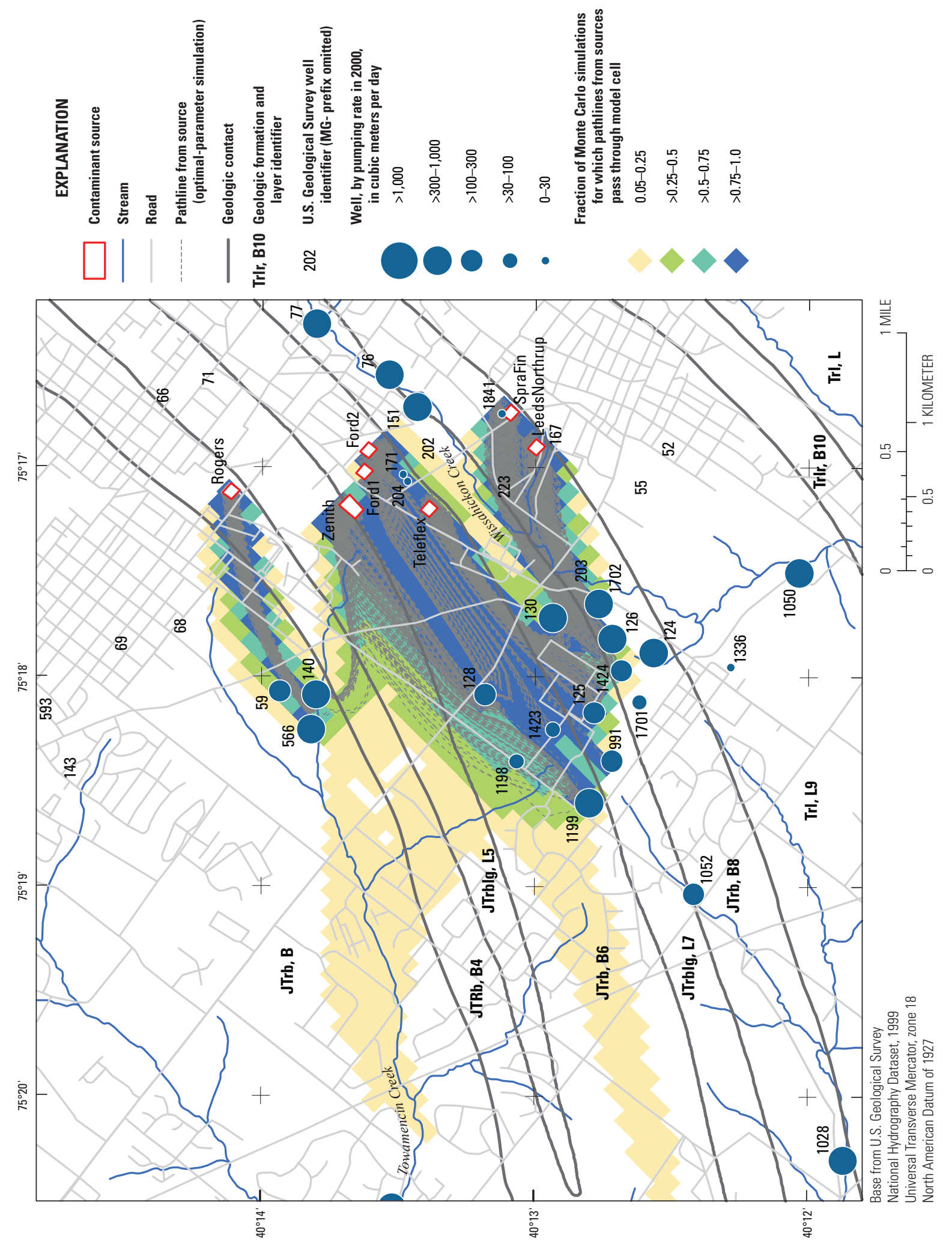

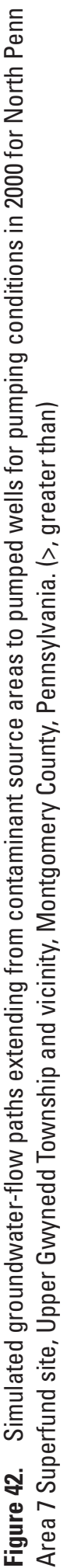




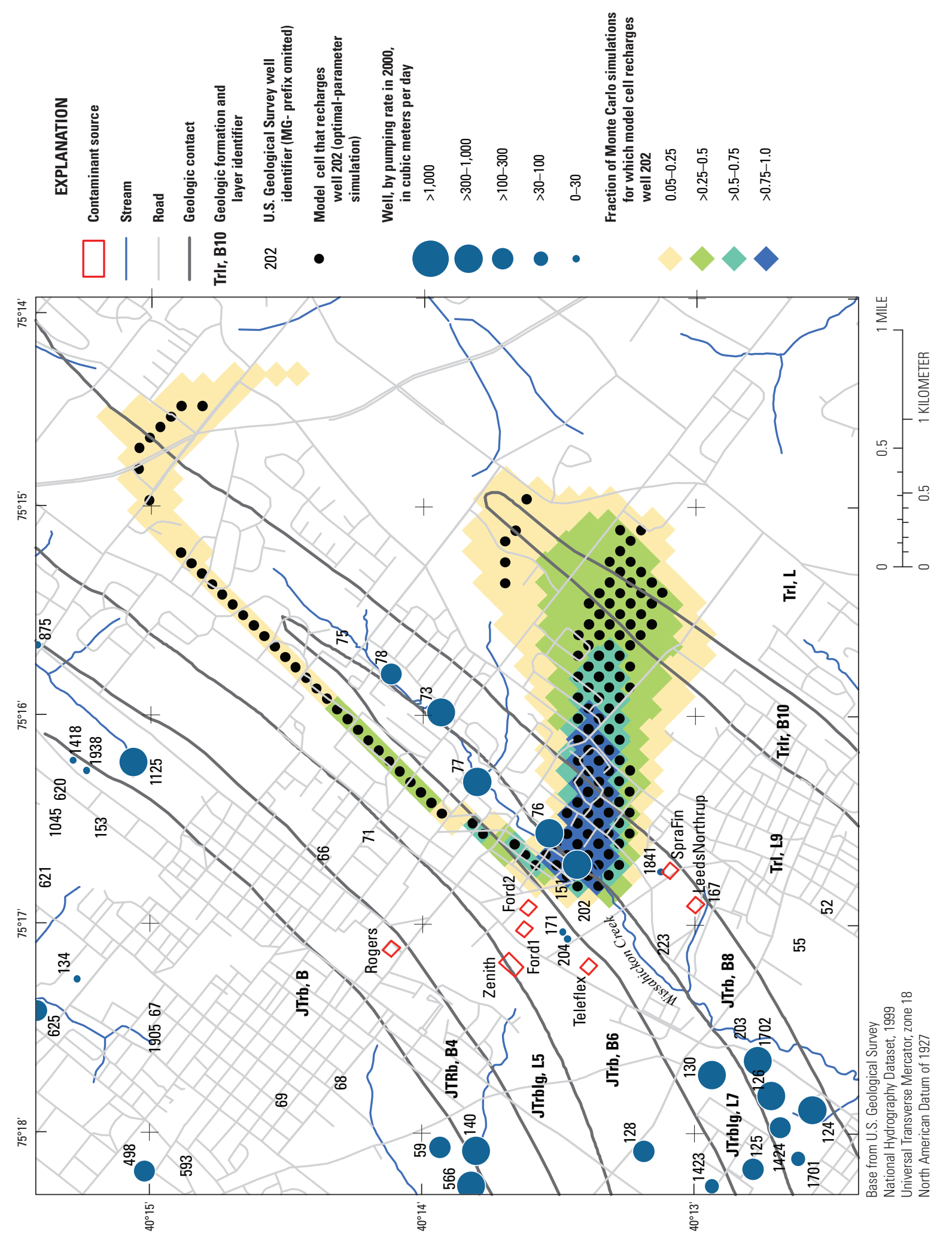

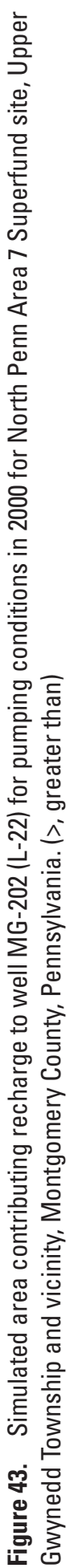




\section{Groundwater-Flow Paths in 2005}

Pumping rates in the vicinity of North Penn Area 7, and in the model domain as a whole, were somewhat higher in 2005 (a calibration period) than in 2000, although 2005 rates were lower than 1990 and 1996 rates. Simulated deterministic and probabilistic groundwater-flow paths from contaminant sources in North Penn Area 7 discharge to the contributing area of Merck wells (including MG-125, MG-128, MG-991, MG-1198, MG-1199, and MG-1423), except for the source area at the Rogers facility (North Penn Area 6), which discharges to the area contributing to pumped production wells MG-59, MG-140, and MG-566 (fig. 44). Simulated deterministic and probabilistic groundwater-flow paths from Leeds $\&$ Northrup and Spra-Fin sources do not flow beneath Wissahickon Creek but flow more directly to the southwest and discharge to wells at Merck. The frequencies for probabilistic flow paths from all North Penn Area 7 source areas to pass near or arrive at Merck wells are higher than 0.75.

As in the 1990, 1996, and 2000 simulations, production well MG-202 (L-22) does not capture any deterministic groundwater-flow paths from identified sources in North Penn Area 7 (fig. 44). The frequency for probabilistic flow paths that extend from contaminant sources to areas near well MG-202 (L-22) is less than 0.05 .

In the simulation of contributing area, modeled source locations do not appear likely to contribute recharge to well MG-202 (L-22) under conditions in 2005 (fig. 45), as was the case for 1990, 1996, and 2000 simulations. The frequency of probabilistic simulations for which recharge from identified contaminant sources in North Penn Area 7 flows to MG-202 (L-22) is less than 0.05 . The deterministic contributing area simulated using optimal model parameters for withdrawals from MG-202 (L-22) is east of the pumped well; a thin and discontinuous contributing area extends to the northeast. The probabilistic contributing area also extends to the far northeast, but the frequencies are low, less than 0.25 at any particular location. As in the 1990, 1996, and 2000 simulations, the probabilistic contributing area to MG-202 (L-22) has a complex shape caused by nearby pumped wells and surfacewater/groundwater interaction in the headwaters of the Wissahickon Creek. The probabilistic contributing area is larger than in previous simulations, apparently as a result, in part, of the change in the number (decreased to three in 2005) of large pumped wells that affect the complex flow field. Under simulated steady-state conditions, some water flowing to well MG-202 (L-22) is recharged beyond the contributing areas for nearby pumped wells MG-76 (L-17) and MG-78 (L-19) in the Wissahickon well field. The contributing areas for wells MG-76 (L-17) and MG-78 (L-19) are separated by a thin strip that contributes flow to well MG-202 (L-22).

\section{Groundwater/Surface-Water Interactions}

Analysis of computed groundwater discharge to streams shows the complex flow patterns in the headwaters area of
Wissahickon Creek in the vicinity of North Penn Area 7 where groundwater withdrawals are a large part of the water budget (table 8). Streamflow gain, or discharge from the groundwater to surface water, occurs in the model where the aquifer hydraulic head is higher than the specified hydraulic head in the stream (Prudic 1989). In contrast, if the simulated aquifer hydraulic head is lower than the specified hydraulic head in the stream, then streamflow loss, or recharge of the groundwater by surface water, occurs. Under 2005 hydrologic conditions, the Wissahickon Creek has both gaining and losing reaches in the vicinity of North Penn Area 7 (fig. 46). Away from pumping wells, the streams generally gain water; this also occurs in sections of Wissahickon Creek upstream from pumped wells. Stream loss, in some cases, results in total depletion of the streamflow. Sections of the Wissahickon Creek, near and upstream and downstream from Sumneytown Pike (approximate southern boundary of the North Penn Area 7) are dry in the simulation because of large groundwater withdrawals in this area. These results are consistent with observed streamflow in the study area in previous studies (Senior and Goode, 1999) and are reported in the section "Streamflow Measurements and Groundwater/Surface-Water Relations." Most of the groundwater removed by pumping is eventually discharged to surface water at wastewatertreatment-plant discharge points on the Wissahickon Creek or other nearby streams. Downstream from these discharge points, measured base flow may be relatively high, whereas the stream may be dry during low-flow conditions upstream from the discharge points.

\section{Simulated Shutdown of Well MG-202}

Well MG-202 (L-22) produces water contaminated with VOCs, as documented since the 1980s (Martin, 1981; CH2M Hill, 1992), yet water from the nearby production well MG-76 (L-17) has rarely contained contaminants in detectable concentrations. Anecdotal accounts indicate that the pumping of well MG-202 (L-22) effectively "protects" well MG-76 (L-17) from drawing in contaminated water. A hypothetical simulation was run using the calibrated groundwater-flow model for North Penn Area 7 under 2005 conditions to estimate the contributing area for MG-76 (L-17) with and without MG-202 (L-22) pumping. A transient simulation of recovery following the shutdown of MG-202 (L-22) was conducted using 2005 pumping and recharge rates; results were compared with the recovery measured in December 2004.

Results of the simulated shutdown of MG-202 (L-22) under steady-state 2005 conditions show that the area contributing recharge for well MG-76 (L-17) when well MG-202 (L-22) is not pumping shifts downstream (fig. 47), overlapping, and similar in shape to, the area contributing recharge for well MG-202 (L-22) when both wells are pumping (fig. 45). This result is consistent with the anecdotal account that the pumping of well MG-202 (L-22) "protects" well MG-76 (L-17) from drawing in contaminated water if the contaminant source is in the overlapping area that contributes recharge 


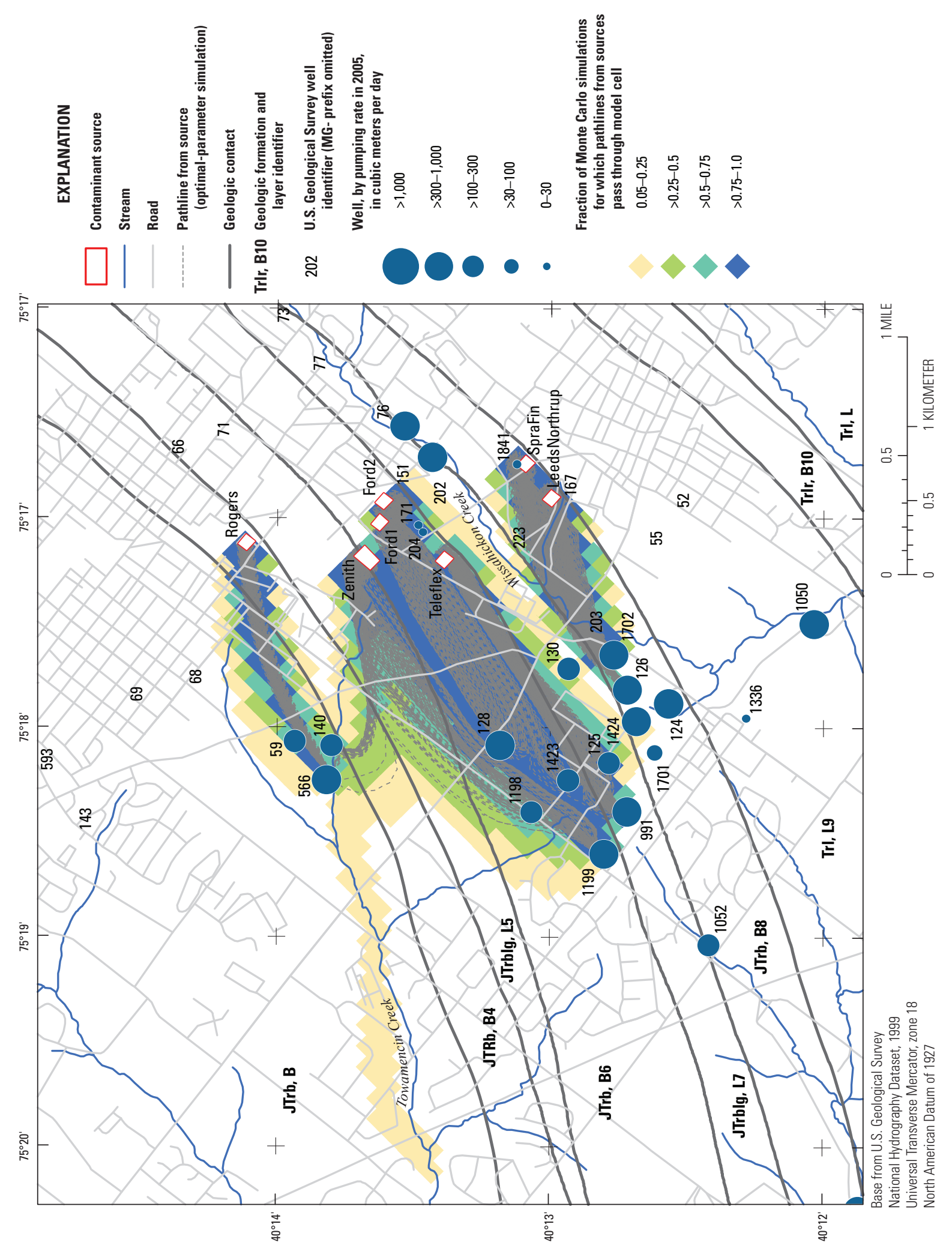

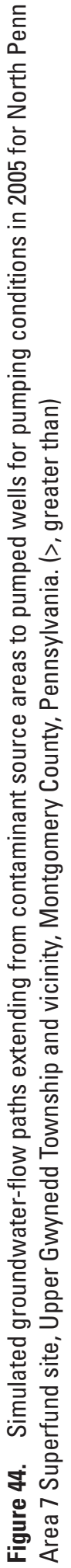




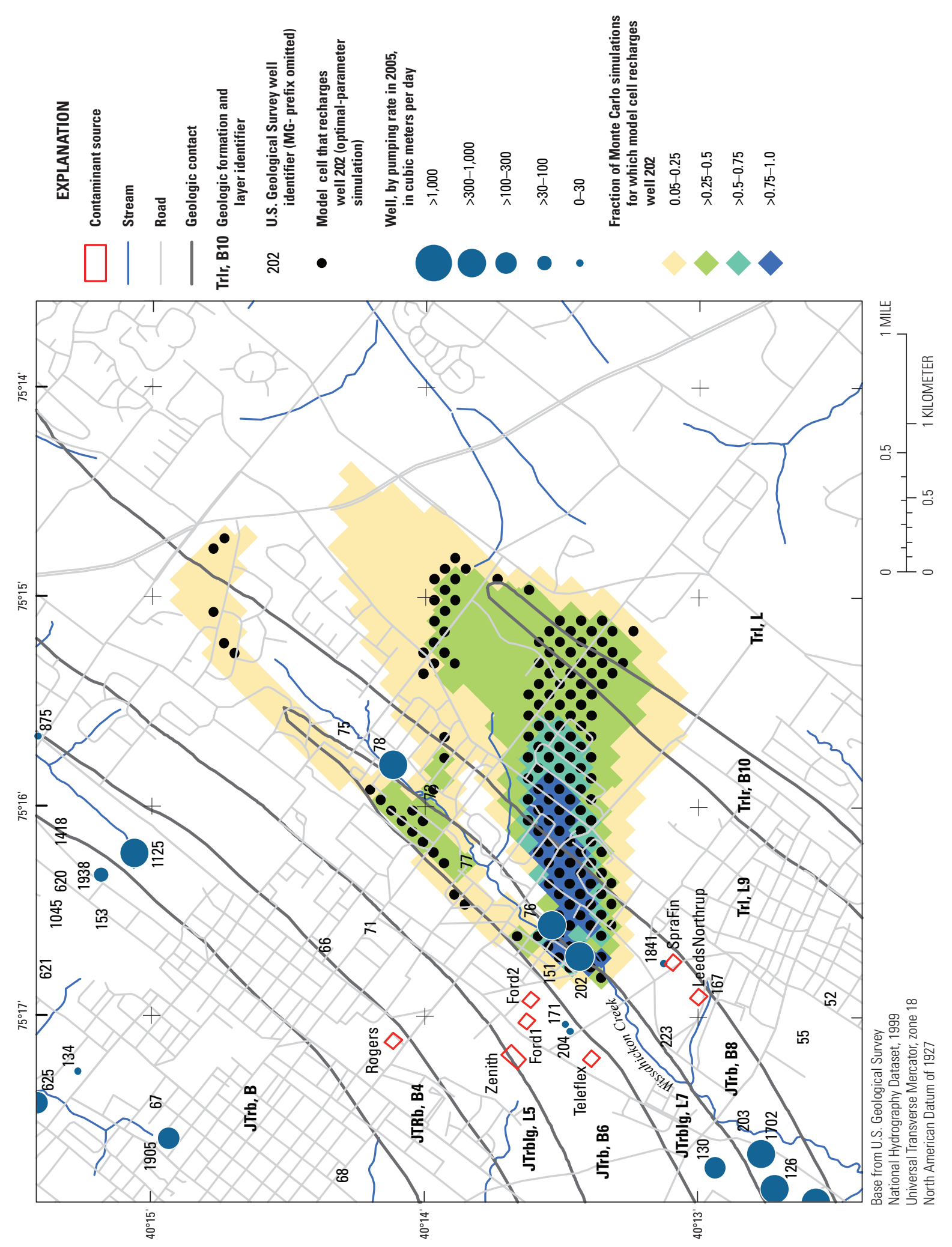

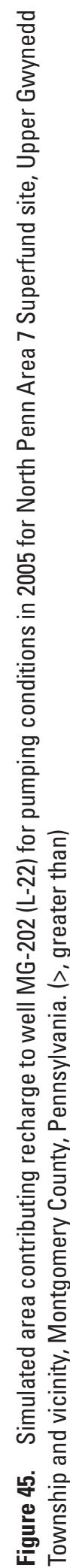




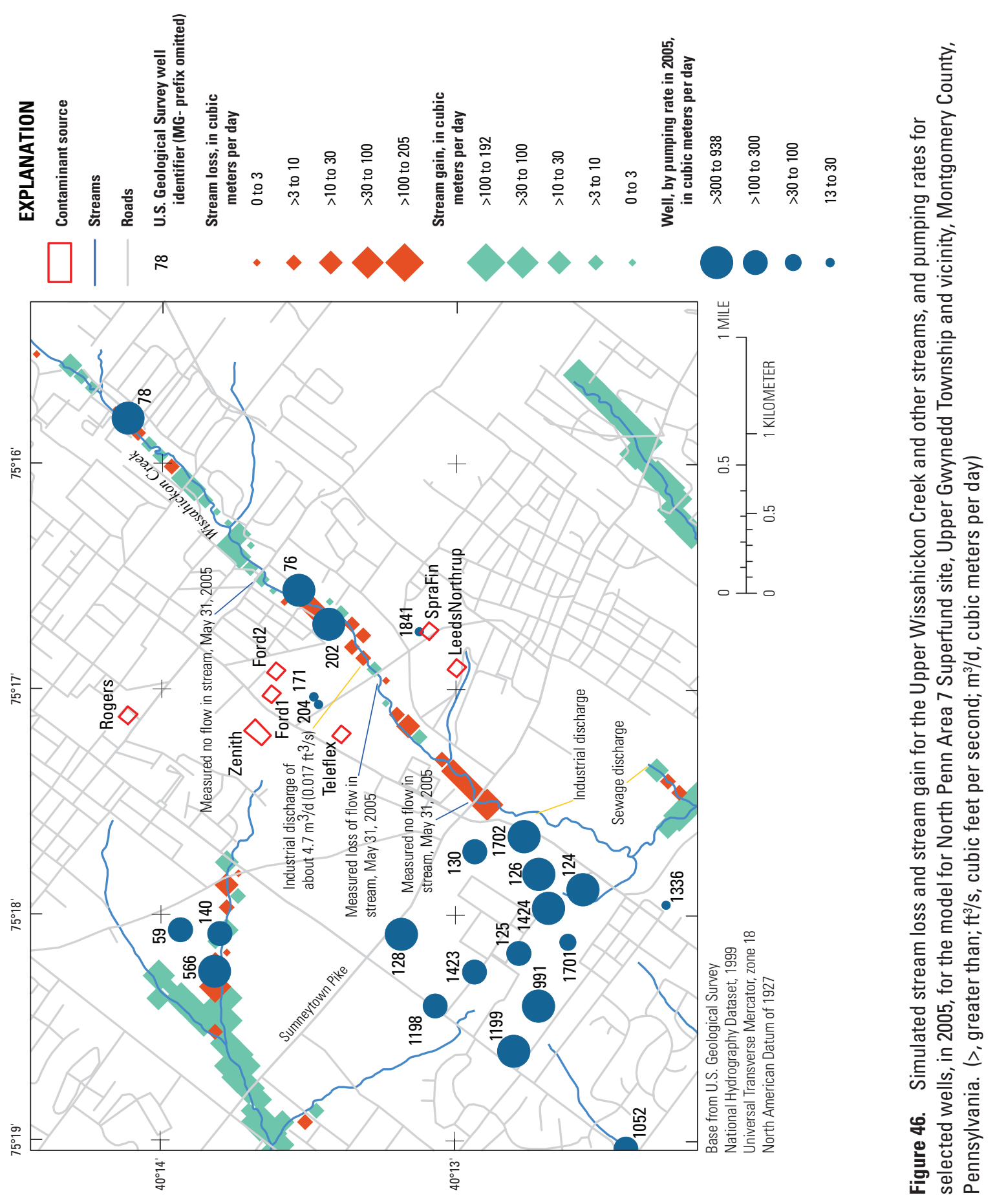




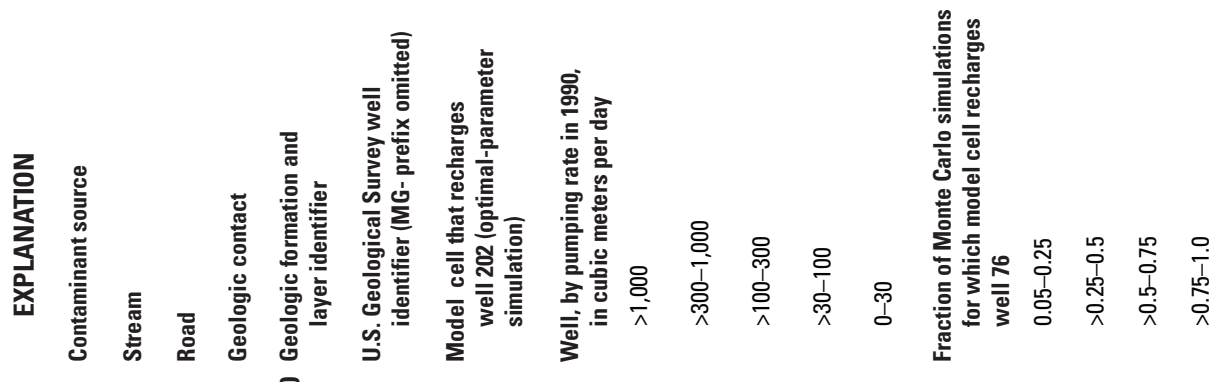

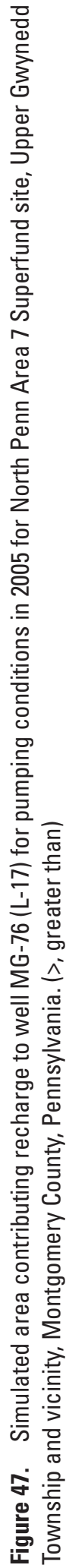


captured by the wells. However, this area (figs. 45 and 47) does not include known contaminant sources, indicating the presence of an unknown or unidentified contaminant source.

The shutdown of well MG-202 (L-22) was also simulated under transient conditions using 2005 pumping and recharge to allow comparison of the groundwater-model results to measurements made in observation wells during the December 2004 shutdown, described earlier in this report. The initial conditions for this simulation were the steadystate potentiometric heads corresponding to 2005 pumping and recharge rates. For the transient simulation, the specific yield was set equal to 0.2 , and specific storage was set equal to 0.00001 . These values of aquifer storage parameters were not calibrated, but were selected from the literature to approximately represent local conditions. A specific yield of 0.2 was reported by Johnson (1967) for silt loess. For comparison, in other simulations of groundwater-flow in fractured rock in the Newark Basin in New Jersey, Lewis-Brown and Rice (2002) used a specific yield value of 0.15 for overburden overlying the Lockatong Formation, and Tiedeman and others (2010) used a specific storage value of 0.00001 for weathered and unweathered fractured rock of the Lockatong Formation. The model layers representing mapped geologic units were subdivided into three sub-layers for the transient simulation. The pumped well MG-202 (L-22) intersects layers 8 and 9 but withdraws water primarily from layer 8 . The simulated recovery from the shutdown of well MG-202 (L-22) generally is consistent with measurements made during shutdown tests of that well in 2002 and 2004, which are described by Senior and others $(2005 ; 2008)$ and previously in this report. The recovery in water levels after 1 day $(1,440$ minutes) in the middle sub-layer of model layer 8 is depicted in figure $48 \mathrm{~A}$, which shows that the distribution of changes in water levels is elongated in the strike direction but extends downdip to the northwest. For some wells, such as MG-72 (L-13), the simulated recovery is similar in magnitude to the actual measured changes in water levels during shutdown tests in 2002 and 2004 (fig. 15), and overall, the general shape and magnitude of simulated recovery is consistent with measured water-level changes. Little to no recovery in water levels was simulated near Spra-Fin, which is consistent with measured water levels in well MG-175 during the 2002 shutdown test. The recovery in layer 8 is much larger (at least one order of magnitude) than in the overlying layer 7 , as indicated by simulated changes in water levels in the middle sub-layer of model layers 7 and 8 after 7 days (figs. $48 B$ and $48 C$ ). Thus, the regional-scale groundwater-flow model, in general, is able to simulate aquifer response at the scale of the MG-202 aquifer test, although the model does not include sufficient detail to accurately simulate all measured water-level changes.

Transmissivity values estimated from measured waterlevel changes in response to shutdown and restart of pumping in well MG-202 (L-22) using the Theis (1935) analytical method ranged from about 700 to $2,300 \mathrm{ft}^{2} / \mathrm{d}$ (65 to $214 \mathrm{~m}^{2} / \mathrm{d}$ ) in the 2004 test (Senior and others, 2008) and 770 to $1,625 \mathrm{ft}^{2} / \mathrm{d}\left(72\right.$ to $151 \mathrm{~m}^{2} / \mathrm{d}$ ) in the 2002 test (Senior and others, 2005). Although the application of the Theis method to the fractured-rock setting does not account for anisotropy or heterogeneity, transmissivity values determined using this analytical approach may be considered rough estimates and are similar in magnitude to the transmissivity of about $904 \mathrm{ft}^{2} / \mathrm{d}\left(84 \mathrm{~m}^{2} / \mathrm{d}\right)$ in the strike direction [optimum $\mathrm{K}$ of $3.72 \mathrm{ft} / \mathrm{d}(1.135 \mathrm{~m} / \mathrm{d})$ multiplied by maximum layer thickness of $243 \mathrm{ft}(74 \mathrm{~m})$ ] estimated using the computer model for layer 8 (table 7).

\section{Relation Between Water Quality and Groundwater Flow}

Soluble chemical constituents may be transported in groundwater and can act as tracers of groundwater-flow paths. Chemical constituents that are introduced at the land surface by human activities may enter the groundwater system in recharge through soils and unsaturated aquifer materials. A constituent that is relatively conservative (not degradable, readily adsorbed, or precipitated to solid phases), such as the dissolved inorganic anion chloride, usually will trace advective groundwater flow more closely than other constituents, such as metals or organic compounds that are more chemically reactive.

Concentrations of constituents in groundwater samples collected by CDM Programs Corporation in fall 2005 are evaluated in relation to results of groundwater-flow simulations for the year 2005 to provide a qualitative assessment of model results, acknowledging that a snapshot of groundwater quality may not exactly match steady-state flow paths. Flow paths change over time because of differences in recharge and pumping rates. Constituents, including contaminants, may be transported to one area and then to another area as groundwater-flow directions change. The observed spatial distribution of selected constituents in groundwater in 2005 generally was supportive of, or consistent with, the model results of the 2005 groundwater-flow simulation at North Penn Area 7.

\section{Inferred Flow Paths from Distribution of Measured Contaminants}

The most common contaminant in groundwater at North Penn Area 7 is TCE. The spatial distribution of TCE in fall 2005 shows that highest TCE concentrations were in or near groundwater-flow paths simulated under steady-state conditions in 2005 (fig. 49A). Notably, TCE was not detected in water samples from most wells that were not in or near flow paths from identified contamination sources; the exception is well MG-202 (L-22) and possibly wells MG-174 and MG-1897 at the former Clearline property. As discussed previously, the simulated contributing area for well MG-202 (L-22) does not include any identified contamination source in North Penn Area 7; therefore, the model results suggest the presence of an unidentified contaminant source of TCE for MG-202 (L-22). 
$\boldsymbol{A}$

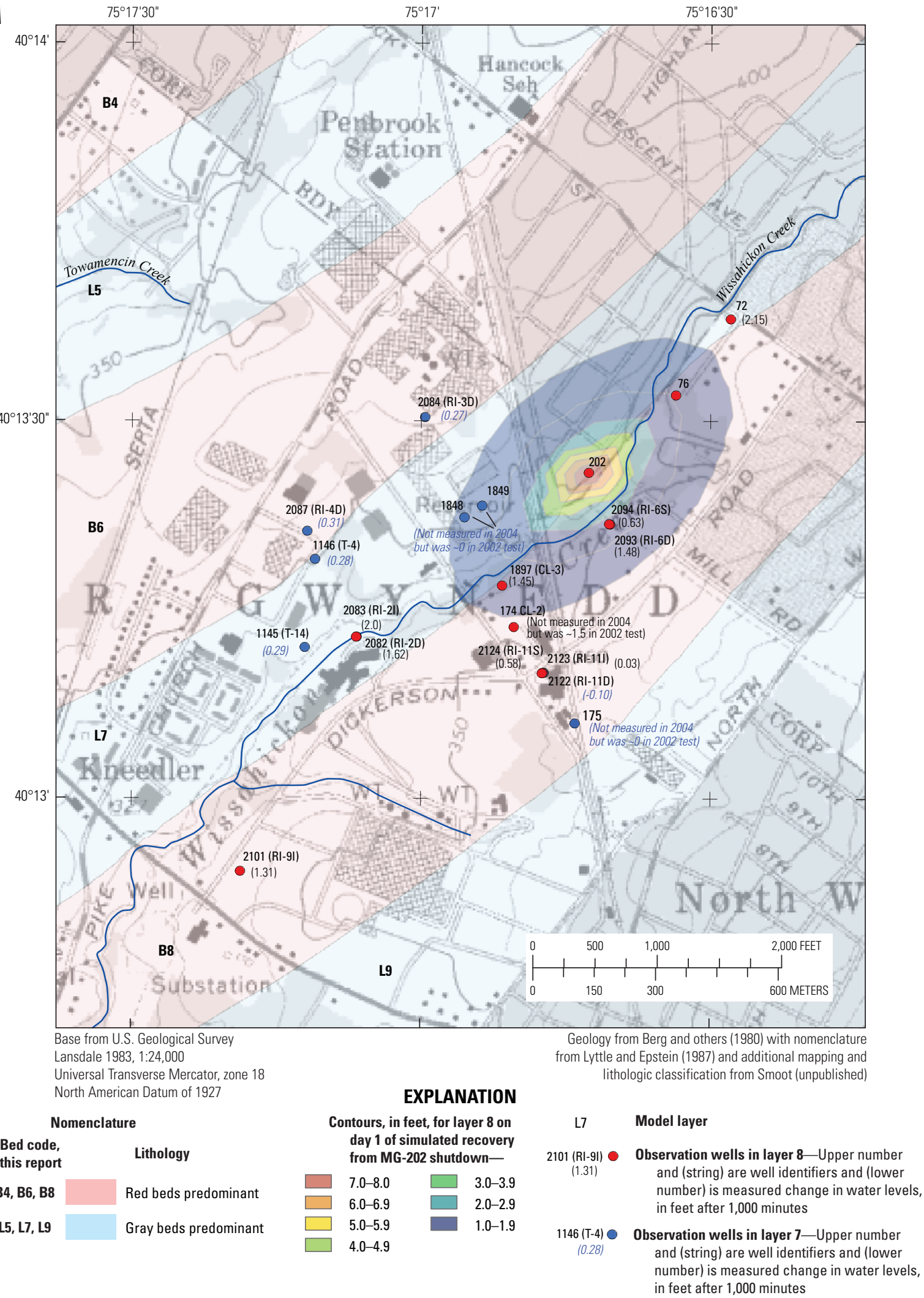

Figure 48. Measured water-level changes in observation wells at 1,000 minutes after shutdown of well MG-202 (L-22) in 2004 and simulated water-level recovery contours in the respective middle sub-layers of model layers after shutdown of well MG-202 (L-22): $A$, model layer 8 at at 1 day (1,440 minutes), $B$, model layer 8 at 7 days, and $C$, model layer 7 at 7 days, North Penn Area 7, Upper Gwynedd Township and vicinity, Montgomery County, Pennsylvania. [See figure 15 for cross-section showing changes in water levels measured in observation wells in 2004 shutdown test of well MG-202 (L-22).] 


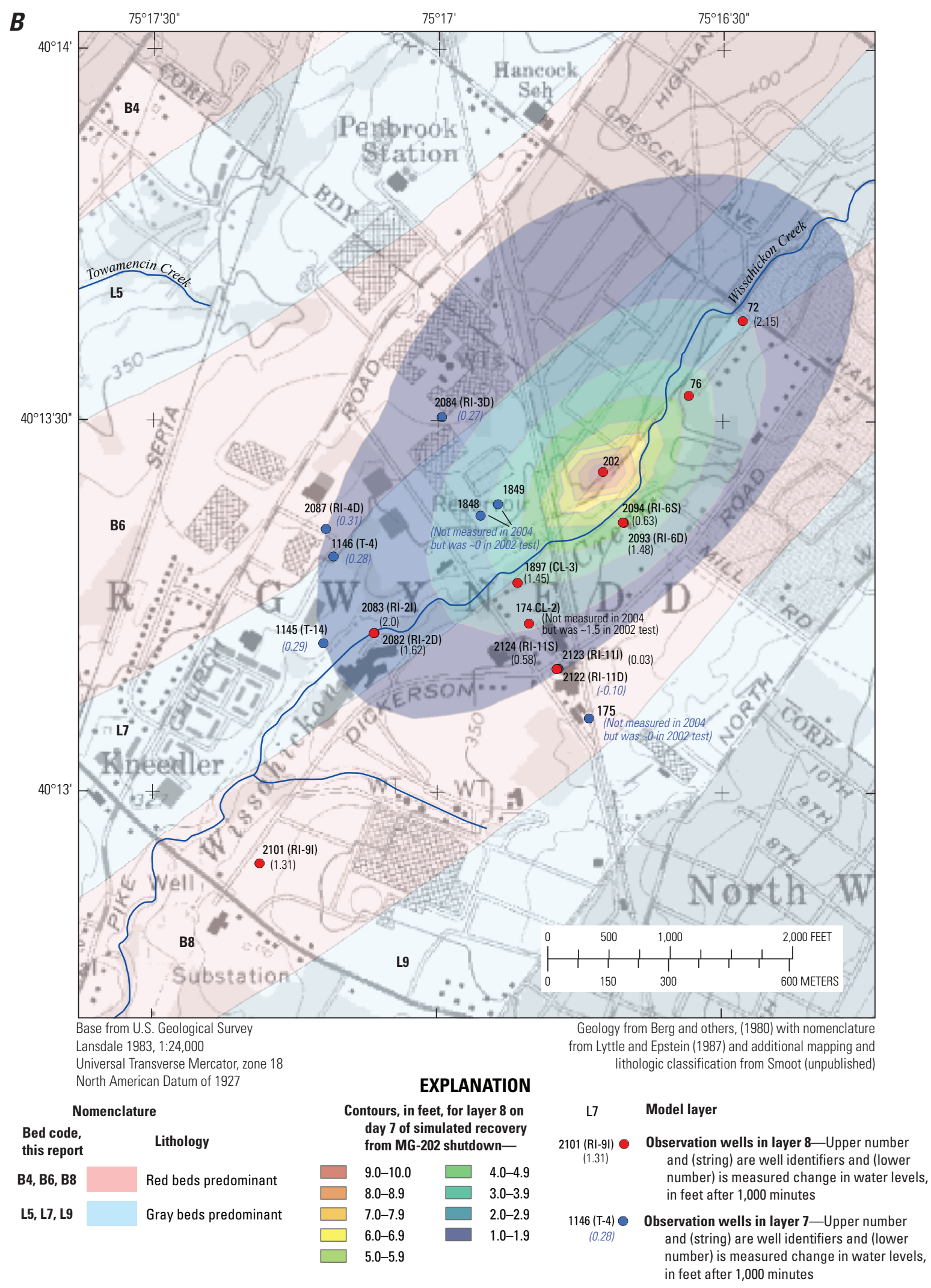

Figure 48. Measured water-level changes in observation wells at 1,000 minutes after shutdown of well MG-202 (L-22) in 2004 and simulated water-level recovery contours in the respective middle sub-layers of model layers after shutdown of well MG-202 (L-22): $A$, model layer 8 at at 1 day (1,440 minutes), B, model layer 8 at 7 days, and $C$, model layer 7 at 7 days, North Penn Area 7, Upper Gwynedd Township and vicinity, Montgomery County, Pennsylvania.-Continued [See figure 15 for cross-section showing changes in water levels measured in observation wells in 2004 shutdown test of well MG-202 (L-22).] 
C

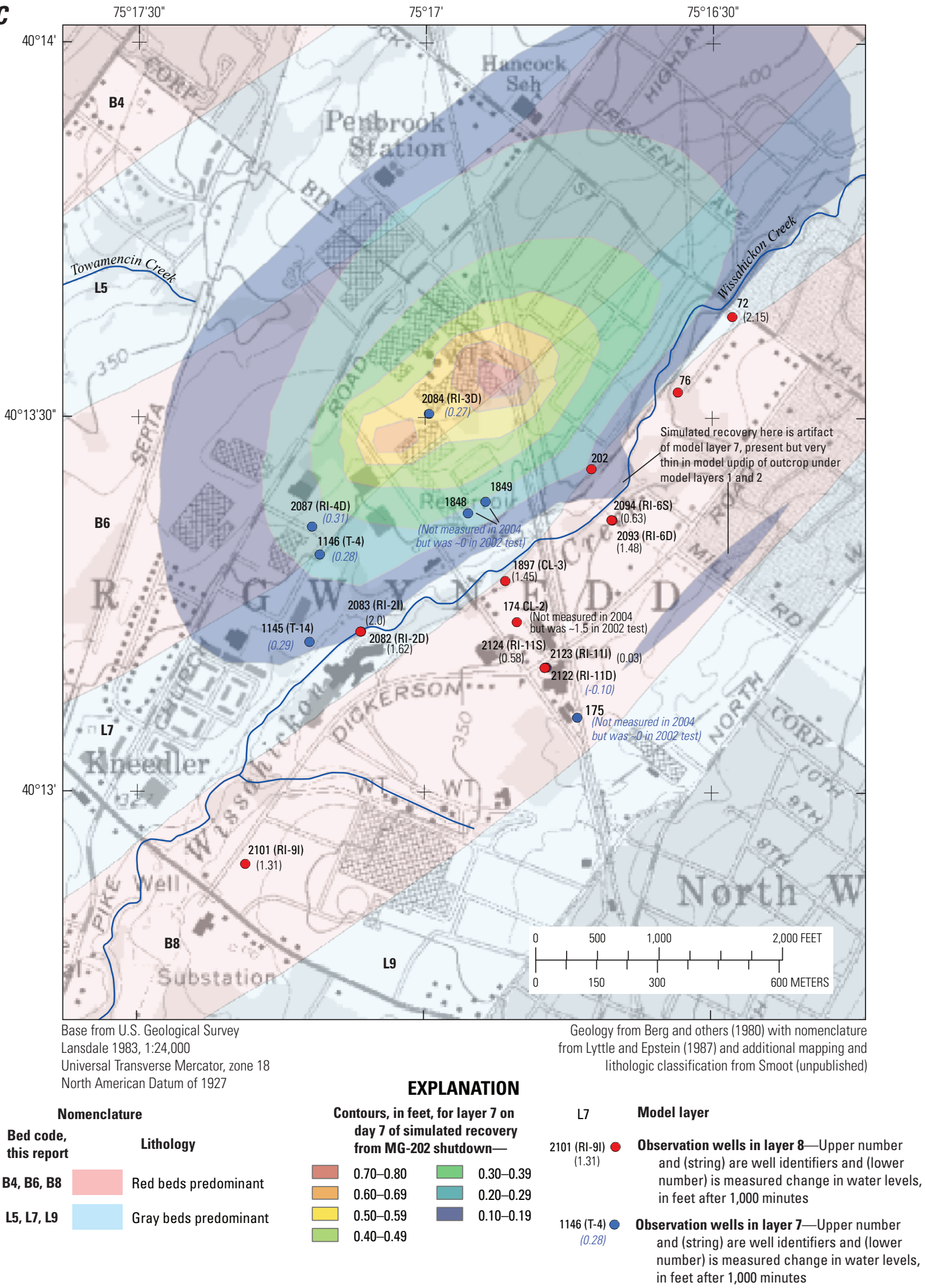

Figure 48. Measured water-level changes in observation wells at 1,000 minutes after shutdown of well MG-202 (L-22) in 2004 and simulated water-level recovery contours in the respective middle sub-layers of model layers after shutdown of well MG-202 (L-22): A, model layer 8 at at 1 day (1,440 minutes), B, model layer 8 at 7 days, and $C$, model layer 7 at 7 days, North Penn Area 7, Upper Gwynedd Township and vicinity, Montgomery County, Pennsylvania.-Continued [See figure 15 for cross-section showing changes in water levels measured in observation wells in 2004 shutdown test of well MG-202 (L-22).] 

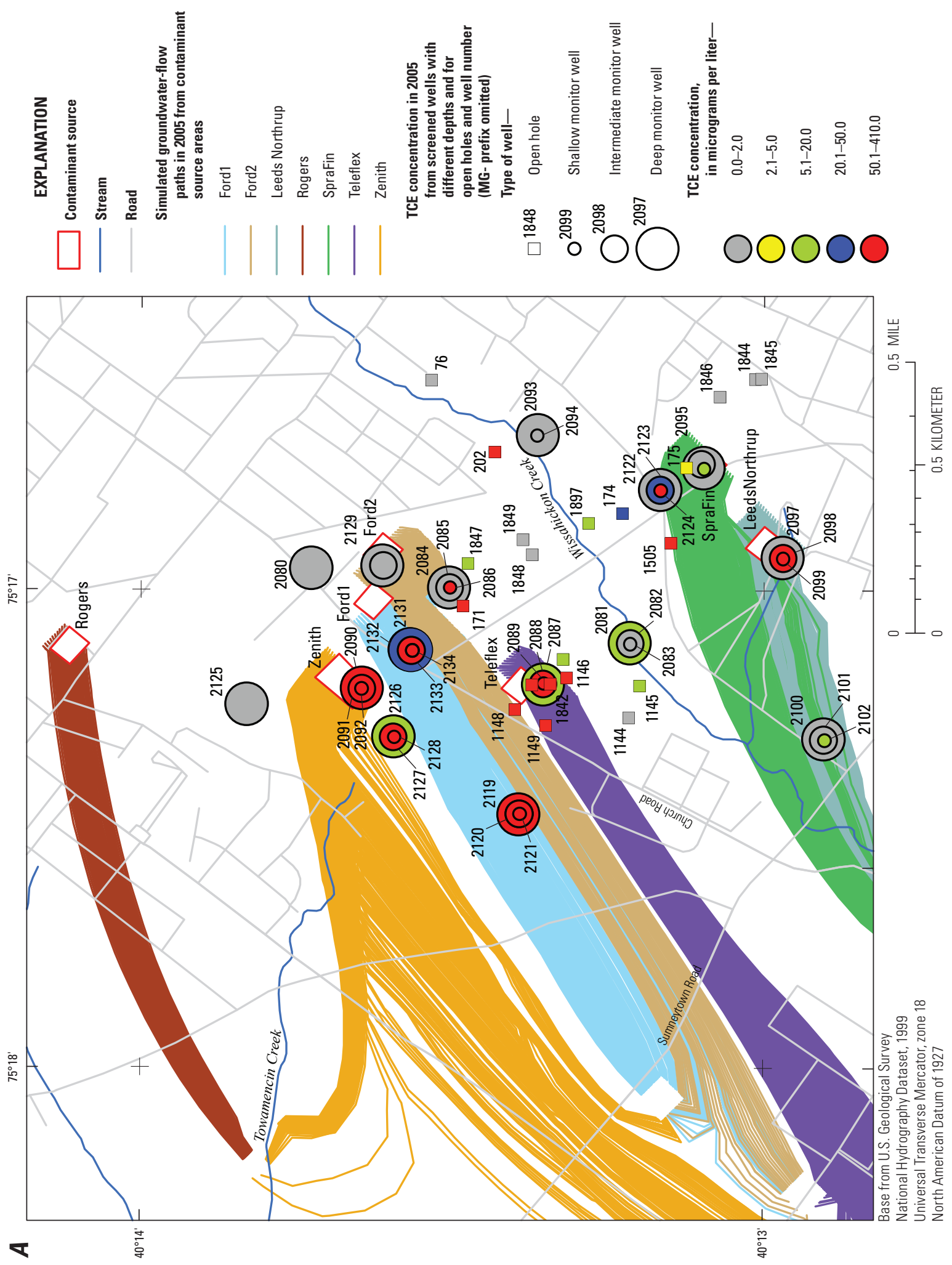

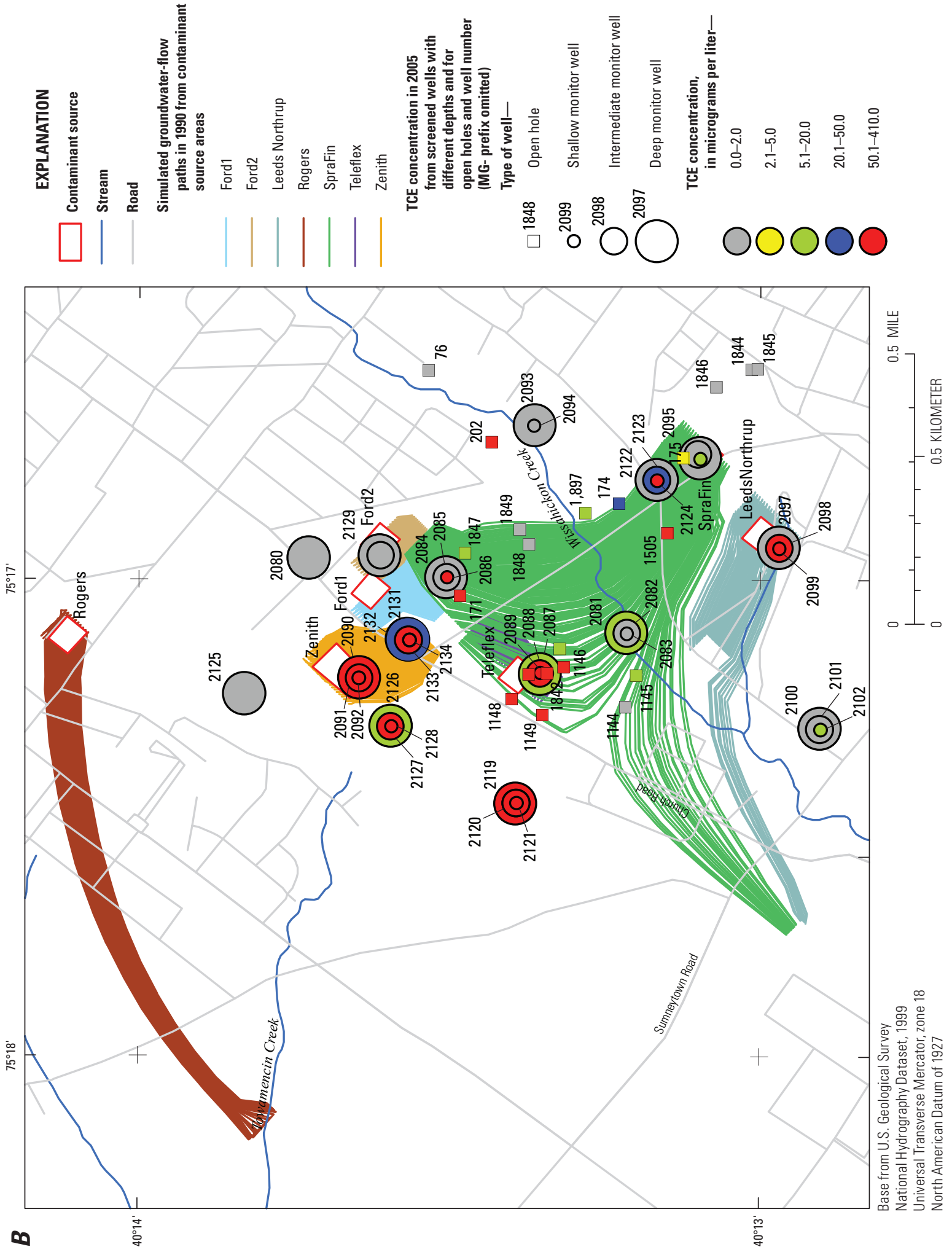

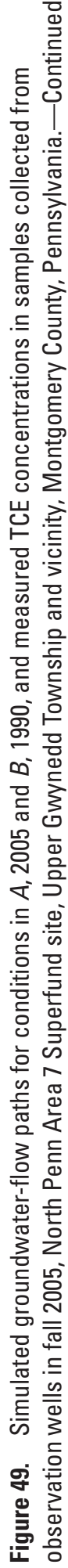


The effects of differences in aquifer stresses on directions of flow paths are depicted in figure $49 B$ where TCE concentrations in fall 2005 are shown with flow paths simulated for 1990 steady-state conditions when more wells were pumping and pumping rates were higher than in 2005. The TCE concentrations in 2005 samples from well clusters west of Church Road [wells MG-2119 (RI-10D), MG-2120 (RI-10I), MG-2121 (RI-10S) of the RI-10 cluster] and near the southern extent of Dickerson Road [wells MG-2100 (RI-9D), MG-2101 (RI-9I), MG-2102 (RI-9S) of the RI-9 cluster] are not in or near simulated deterministic 1990 flow paths (and not along high-frequency probabilistic flow paths; fig. 38), indicating that flow paths from known sources were different in 1990 than in 2005. The 1990 simulated flow paths are similar to those for 2005 in that the simulated 1990 flow paths from identified contaminant sources do not pass near well MG-202, which nevertheless yields water with TCE at concentrations of concern, indicating contamination from an unknown or unidentified source.

In addition to TCE, other VOCs were detected in samples from wells in North Penn Area 7. The fall 2005 spatial distribution of CFC-11 and CFC-113 (fig. $50 \mathrm{~A}$ and B), two VOCs present in relatively low to moderate concentrations (up to 230 and $79 \mu \mathrm{g} / \mathrm{L}$, respectively) in selected groundwater samples, indicate different source areas for these compounds. The distribution of CFC-11 and CFC-113 in groundwater samples generally agrees with the 2005 simulated path lines. CFC-11 primarily was detected in samples from wells west of Church Road (well clusters RI-5, RI-13, and RI-10), two wells in the RI-15 cluster just east of Church Road [MG-2133 (RI-15I), MG-2134 (RI-15S)], and the shallow well [MG-2099 (RI$8 \mathrm{~S}$ )] of the RI-8 cluster east of Wissahickon Creek (fig. 50A). CFC-113 primarily was detected at concentrations higher than those for CFC-11 in samples from wells east of Church Road on the Teleflex property and the shallow well of the RI-8 cluster [well MG-2099 (RI-8S)] east of Wissahickon Creek and at relatively lower concentrations in samples from wells at the Precision Tube facility (MG-171 and MG-204) and former FERCO facility (RI-15 and RI-3 clusters) along strike from Teleflex (fig. 50B). Samples from wells in the RI-8 and RI-15 well clusters contained detectable concentrations of CFC-11 and CFC-113. Analyses of 2006 well samples indicated that CFC-11 and CFC-113 were present in concentrations similar to, or higher than, those reported for 2005 samples, indicating that the spatial distribution pattern of these compounds was persistent over that time period.

The 2005 observed concentrations and 2005 simulated path lines indicate (1) a source of CFC-11 near the RI-5 cluster west of Church Road, (2) a source of CFC-113 on the Teleflex property east of Church Road, and (3) a source of CFC-11 and CFC-113 near RI-8 cluster on the former Leeds \& Northrup property east of Wissahickon Creek. The presence of CFC-113 in samples from wells at the Precision Tube and former FERCO facilities may be a result of previous and current pumping drawing the compound from the Telefex facility, or the $\mathrm{CFC}-113$ could come from independent sources.
CFC-11 and CFC-113 measured in 2005 samples from the shallow and intermediate wells (MG-2099, MG-2098) of the RI- 8 cluster near a contaminant source at the Leeds \& Northrup facility east of Wissahickon Creek were not detected in 2005 samples collected downgradient, possibly because of limited data. Simulated 2005 groundwater-flow paths from this source do not pass directly through areas where wells were sampled for CFC-11 and CFC-113 analysis, although the flow paths pass near the RI-9 well cluster. Neither CFC-11 nor CFC-113 was detected in 2005 samples from wells in the RI-9 well cluster, but low concentrations (less than $1 \mu \mathrm{g} / \mathrm{L}$ ) of both compounds were measured in 2006 samples from the shallow well [MG-2102 (RI-9S)] in the RI-9 cluster.

\section{Inferred Flow Paths from Observed Inorganic Constituent Distribution}

As discussed previously, elevated concentrations of chloride coupled with distinct chloride/bromide mass ratios were measured in samples from well clusters RI-5, R-13, and RI-10 west of Church Road (figs. 22, 28, and 29). The distribution of these inorganic chemical characteristics (figs. 22 and 29) is similar to the spatial distribution of CFC-11 (fig. 50A), indicating a similar source location and (or) similar flow paths for the elevated chloride and CFC-11 in that part of North Penn Area 7.

Boron is another inorganic constituent that appears to occur in a distinct spatial distribution. Boron was detected in elevated concentrations above estimated background concentrations of about $40 \mu \mathrm{g} / \mathrm{L}$ in the 2006 samples from selected wells only. The highest boron concentrations (up to $229 \mu \mathrm{g} / \mathrm{L}$ ) were measured in samples from wells in the RI-6 cluster southeast, updip, and across the Wissahickon Creek from production well MG-202 (L-22) (fig. 26). Relatively elevated boron concentrations also were measured in samples from wells generally downgradient and along strike from the RI-6 cluster. The spatial distribution of the elevated boron may be related to natural geologic occurrence (composition of certain beds) and (or) to groundwater flow through the aquifer from a natural or anthropogenic source near the RI-6 cluster. If the elevated boron were from a source, the spatial distribution would be consistent with the general direction of groundwater flow. The RI- 6 well cluster is at the edge of the 2005 simulated contributing area for well MG-202, and therefore, pumping at MG-202 may not capture all groundwater originating as recharge in the vicinity of the RI- 6 cluster. The boron concentration of $50 \mu \mathrm{g} / \mathrm{L}$, slightly higher than estimated natural background, in the 2006 water sample from well MG-202 (L-22) indicates that the source of elevated boron is relatively small or, if geologically controlled, does not extend far along strike to the northeast of the RI-6 cluster. Boron in MG-202 (L-22) well water also could be a mixture of some water with high boron concentrations from near RI-6 and other water with lower boron concentrations. Analysis for boron isotopes in groundwater might be useful in identifying boron sources 

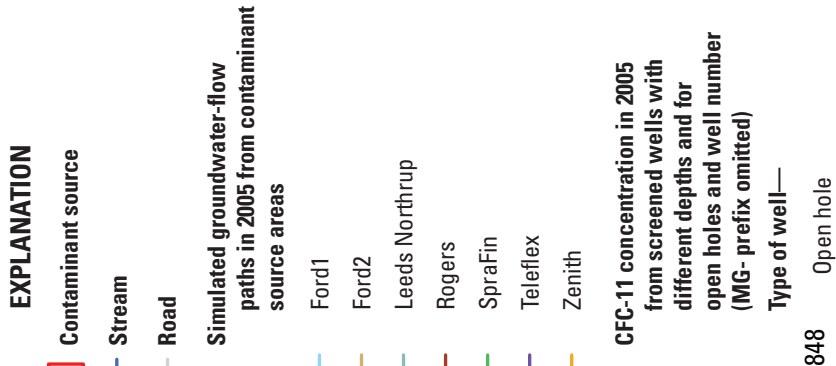

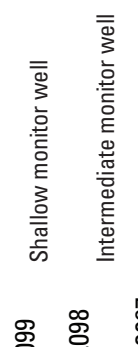

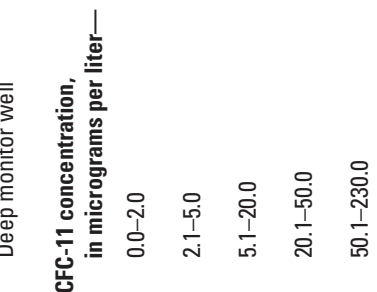

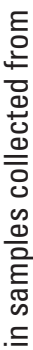

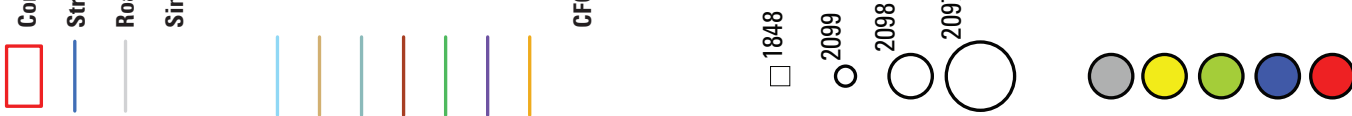

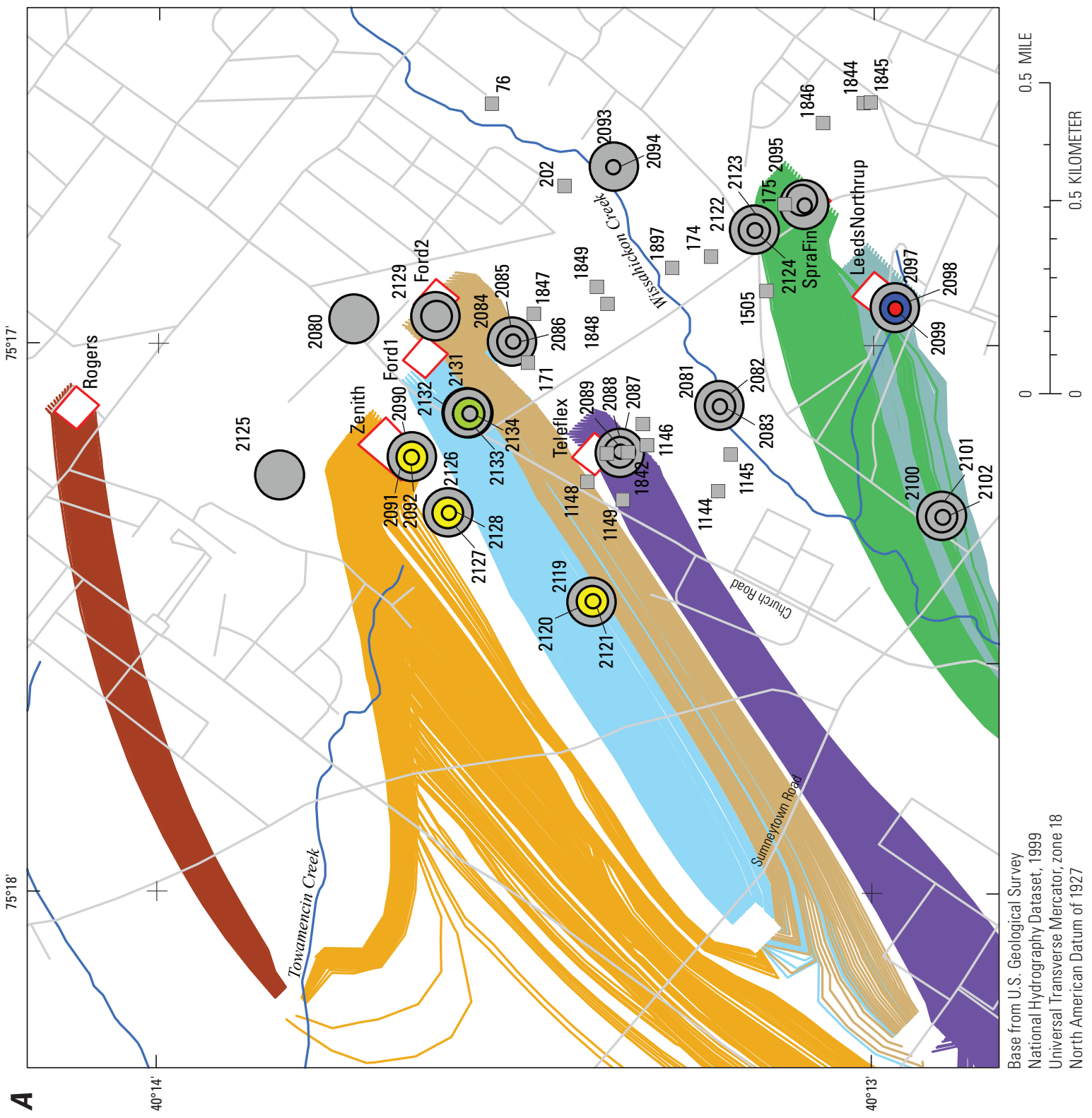



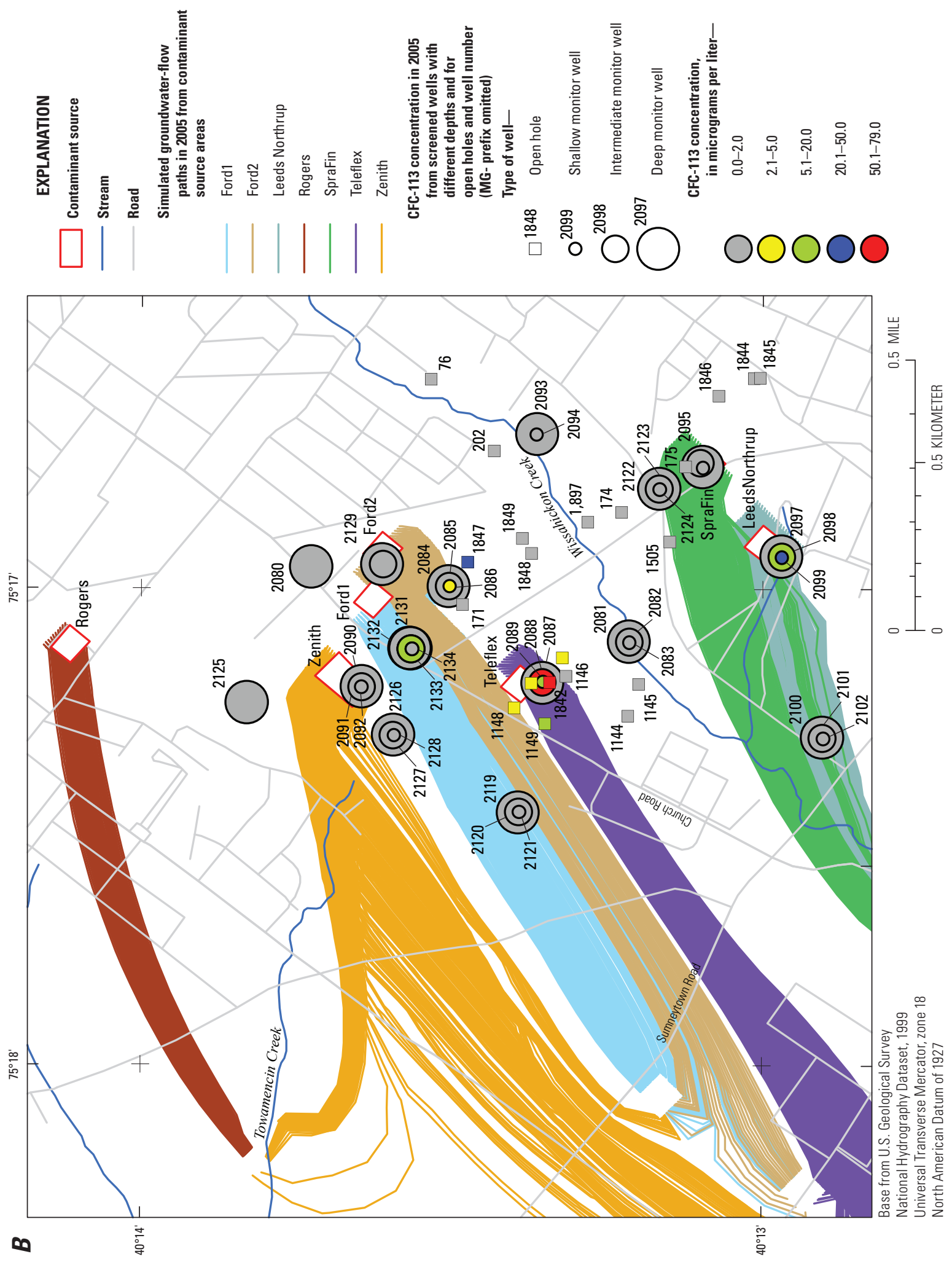

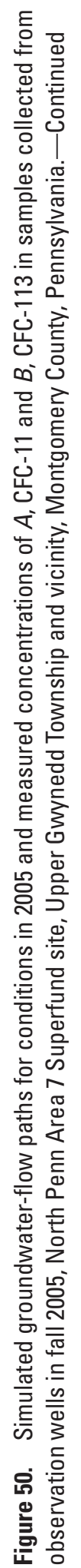


in the area and their relative contribution to water withdrawn from well MG-202 (L-22) and, thus, could be potentially helpful in identifying the location of the unknown source of TCE contamination affecting well MG-202 (L-22).

\section{Limitations and Uncertainties in Predictive Simulations}

Regional groundwater-flow paths in the study area are approximated by the predictive simulations in this report. Although the calibrated regional model reasonably matches overall regional water-level trends, the measurements are not precisely reproduced by the models, partly as the result of the model structure and availability of data. The actual groundwater-flow paths are likely to be more complex than those shown here because of the highly heterogeneous characteristics of the fractured-rock aquifers, and the groundwaterflow paths are likely to change in time because of changing recharge and pumping conditions. Nevertheless, the model and results here can be used to compare the potential effects of alternative groundwater-management methods and to indicate general characteristics of contributing areas for wells in the study area. The uncertainties in the predictive simulations of regional groundwater flow could be reduced by more detailed field studies and longer-term aquifer and tracer tests, which are beyond the scope of this study. Similar additional data also would be needed to simulate groundwater flow at the local scale. The probabilistic groundwater-flow paths indicate that the area that may have contributed recharge to individual pumped wells is larger than that shown for deterministic groundwater-flow paths. Vertical anisotropy of some layers of the model could not be calibrated with the observations available, and these parameters were fixed, rather than calibrated. The effect of uncertainty in the vertical anisotropy was not included in the Monte Carlo simulations.

\section{Summary and Conclusions}

Groundwater in an area near Lansdale and Upper Gwynedd Township in southeastern Pennsylvania is contaminated with organic solvents, and on the basis of investigations in the 1980s that identified several probable industrial sources, the U.S. Environmental Protection Agency (USEPA) placed the area on the National Priority List in 1989 as the North Penn Area 7 Superfund site. Groundwater in and near North Penn Area 7 has been and currently (2012) is withdrawn for water supply. Contaminant migration is of concern as pumping patterns in the area change. In 2000, the U.S. Geological Survey (USGS) and the USEPA began a cooperative study, in which the USGS provided technical assistance for the Remedial Investigation (RI) at the North Penn Area 7 Superfund site. This assistance included describing the groundwater system and simulating groundwater flow on a regional scale.
The study area is underlain by Triassic and Jurassic age sandstones and shales of the Lockatong Formation and Brunswick Group in the Mesozoic Newark Basin. Regionally, these rocks strike northeast and dip to the northwest. The sequence of rocks form a fractured-sedimentary-rock aquifer that acts as a set of confined to partially confined layers of differing permeabilities. The aquifer layers are recharged locally by precipitation through thin soils and discharge locally to streams. Depth to the top of competent bedrock typically is less than $20 \mathrm{ft}$ below land surface. The Wissahickon Creek begins less than 1 mile northeast of the study area and flows southwest, parallel to strike, to bisect North Penn Area 7.

Results of field investigations conducted by USGS at North Penn Area 7, including geophysical logging, singlewell testing of isolated aquifer intervals (packer testing), and aquifer tests with multiple observation wells, support the conceptual model of a layered aquifer with low hydraulic connection across beds and higher hydraulic connection parallel to bedding. Correlation of natural gamma-ray activity in borehole logs for the western part of North Penn Area 7 is possible over distance of hundreds to thousands of feet, indicating lateral continuity of beds that dip about 9 to 10 degrees northwest. Correlation of natural gamma-ray-activity logs appears possible only over smaller distances (less than 1,000 ft) in the eastern part of the study area and may reflect different depositional environments for sedimentary rocks than in the western part of the study area. Vertical hydraulic gradients vary throughout the area, as indicated by measurements of borehole flow in open wells, by different water levels in vertically nested wells, and by different water levels in zones isolated by packers in open wells. Vertical gradients are predominantly upward east of Wissahickon Creek, except where affected by pumping, and downward west of Wissahickon Creek.

Depths to static water levels in wells at North Penn Area 7 from December 2000 through September 2006 ranged from about 6 to $83 \mathrm{ft}$ below land surface and generally were least in shallow wells near streams and greatest in wells affected by nearby pumping or located on hilltops. Water levels fluctuated seasonally in response to changes in recharge and were lowest during dry periods in 2001 and 2002. Regional groundwater levels mapped by USGS in 2000 and measured in several synoptic rounds from 2000 through 2005 indicate a potentiometric surface similar to topography, except in areas affected by relatively high pumping rates. Periodic base-flow stream measurements at selected sites on Wissahickon Creek from December 2000 through September 2005 show that the stream lost water between two sites on a reach in the study area when groundwater levels were low and gained water when groundwater levels were relatively high. The stream frequently was dry (no measureable base flow) at the most downstream site on Wissahickon Creek (at Sumneytown Road) that was measured for the North Penn Area 7 study.

Transmissivity values calculated from pumping rates and drawdown in isolated intervals in 11 existing wells and the 15 deepest new monitor wells drilled for the RI ranged over three orders of magnitude ( 2.8 to 2,290 square feet per day). 
Transmissivity values showed some relation to depth over the range of depths tested; the full range of transmissivities was measured throughout the 300-ft thickness of the aquifer penetrated by the new deep monitor wells. When the transmissivities of tested intervals in the 15 deepest monitor wells, which are of similar depths, were grouped by depth in ranges of $50 \mathrm{ft}$, the transmissivities of the shallowest zones and deepest zones tested (interval midpoints of 0 to 50 and 251 to $300 \mathrm{ft}$ below land surface, respectively) were statistically significantly different (smaller) than transmissivities of intermediate depths, as determined by the non-parametric Kruskall-Wallis test using a p-value of 0.05 . Possible explanations for the apparent differences in transmissivity with depth are that weathering may reduce the permeability of the shallowest intervals and that the frequency of high-permeability zones decreases with depth below $250 \mathrm{ft}$ below land surface.

The structure of dipping beds appears to control hydraulic connections in the fractured-rock aquifer, as determined from water-level responses in observation wells to the shutdown and restart of pumping in production well MG-202 (L-22). Water-level changes measured in nearby monitor wells during packer testing of well MG-2131 (RI-15DD) show similar structural/stratigraphic controls on hydraulic connections; water-level changes also show that long open sections of boreholes can act as short circuits to connect fractures in layers of the aquifer that under natural conditions are separated.

Groundwater samples collected by CDM from existing and new monitor wells during three rounds of sampling during 2001-06 as part of the RI to assess the extent of groundwater contamination at North Penn Area 7 were analyzed for VOCs in all rounds and for selected major ions, metals, inorganic constituents, semi-volatile organic compounds, and (or) pesticides in one or more rounds. The main contaminants identified in groundwater from the three rounds of sampling are VOCs; trichloroethylene (TCE) is the VOC most frequently detected and measured at the highest concentration (up to $650 \mu \mathrm{g} / \mathrm{L}$ in monitor well MG-2124 (RI-11S). Other detected VOCs include (but are not limited to) tetrachloroethylene, cis-1,2-DCE, 1,1,1-TCA, 1,1-DCE, vinyl chloride, CFC-11, and CFC-113.

Water samples were analyzed for the additional inorganic constituents, including chloride, bromide, boron, sulfate, and silica, to determine the ions causing the high specific conductance in water from some wells identified through geophysical logging and packer tests and to potentially aid in the understanding of the groundwater-flow system and (or) determine potential contaminant sources and (or) pathways. Chloride concentrations were elevated above the estimated natural background of 10 milligrams per liter $(\mathrm{mg} / \mathrm{L})$ in most groundwater samples, generally decreased with depth, and were highly elevated (100 to $350 \mathrm{mg} / \mathrm{L}$ ) in water samples from wells with high specific conductance in the western part of North Penn Area 7, indicating dissolved salts are the probable cause of the high conductance there. Chloride/bromide mass ratios indicate that sources of chloride in water from wells west of and along Church Road appear to differ from other locations at North Penn Area 7 and probably include substances other than road salt. Sulfate concentrations in samples ranged from 10 to $68.6 \mathrm{mg} / \mathrm{L}$, were not elevated above background levels estimated from regional studies, showed no strong pattern in relation to depth or spatial distribution, and were not high enough to limit anaerobic degradation of VOCs. Silica concentrations, a possible surrogate for residence time, generally decreased with depth like chloride, indicating possible rapid recharge through preferential pathways to deep groundwater. Silica concentrations also indicate that shallow groundwater may follow different, slower flow paths than deeper groundwater. Boron concentrations in water samples from wells at North Penn Area 7 ranged from less than 20 to 220 micrograms per liter $(\mu \mathrm{g} / \mathrm{L})$ and were highest in the RI-6 well cluster and wells along strike from that cluster. The spatial distribution of the slightly to moderately elevated boron concentrations (greater than $40 \mu \mathrm{g} / \mathrm{L}$ ) may be related to a natural occurrence of boron in the geologic formation that follows geologic structure (bedding orientation) or may trace groundwater transport partly controlled by geologic structure from a natural or anthropogenic source (such as waste-disposal facilities).

Groundwater flow in and near North Penn Area 7 under steady-state conditions was simulated by use of a numerical model (MODFLOW-2000). The model, intended to simulate groundwater flow at a regional scale, was oriented parallel to regional strike and consisted of multiple layers. The top two layers represent saprolite and highly weathered rock near the surface. The dipping sedimentary formations that underlie the study area were modeled using dipping model layers for intermediate and deep zones of unweathered, fractured rock. The beds and their geometry were identified on the basis of geologic mapping of the Lockatong Formation and Brunswick Group and transitional beds (maps of the beds are not published). The model does not include detailed structure to account for local-scale differences in hydraulic properties, with the result that local-scale groundwater flow may not be well simulated. Additional detailed multi-well aquifer tests would be needed to establish the extent of interconnection between intervals at the local scale to address remediation of contamination at each source area.

The regional groundwater-flow model was calibrated to measured water levels $(1996,2000$, and 2005) and base flow estimated from selected streamflow measurements by use of nonlinear-regression parameter-estimation algorithms. Estimated model parameters include hydraulic conductivity (subhorizontal and vertical), anisotropy of hydraulic conductivity, streambed hydraulic conductivity, and recharge during calibration periods. Vertical anisotropy of some layers of the model could not be calibrated with the observations available and, consequently, was fixed for these layers. Estimated hydraulic conductivity ranges from 0.001 to 1.67 meters per day $(\mathrm{m} / \mathrm{d})(0.0032$ to $5.5 \mathrm{ft} / \mathrm{d})$. The calibrated regional model indicates that the aquifer appears to be anisotropic; hydraulic conductivity is greatest parallel to the strike of bedding of the dipping sedimentary formations underlying the area and 
smallest in the cross-bed (dip) direction. The ratio of minimum to maximum subhorizontal hydraulic conductivity ranges from $1 / 1$ to $1 / 8.5$, and the ratio of vertical to (sub)horizontal hydraulic conductivity ranges from $1 / 1$ to $1 / 478$. Estimated recharge rates corresponding to calibration periods in 1996, 2000, and 2005 are 148, 109, and 124 millimeters per year (mm/yr) (5.8, 4.3 , and $4.9 \mathrm{in} / \mathrm{yr}$ ), respectively.

The calibrated groundwater-flow model was used to simulate groundwater flow during periods of relatively high withdrawals (pumpage) (1990) and relatively low withdrawals (2000 and 2005). Groundwater-flow paths originating from recharge near known source areas of soil contamination were simulated. Pumped industrial wells captured groundwater from several of these sources. Because pumping at some of these wells ceased or decreased after 1990, groundwater from those sources was no longer captured at those wells. Greater amounts of contaminated groundwater moved away from North Penn Area 7 Superfund site to surrounding areas under pumping conditions in 1996, 2000, and 2005 than in 1990. Changes in the hydraulic properties of the model result in changes in the simulated flow paths of groundwater from contaminant source areas to pumped wells, and this uncertainty in the groundwater-flow paths was illustrated through Monte Carlo simulations. The effect of uncertainty in the vertical anisotropy was not included in the Monte Carlo simulations because limited available field data precluded calibration of vertical anisotropy in the model. The probabilistic simulations show that the groundwater-flow paths from potential areas of contaminant sources are generally consistent with deterministic paths but that uncertainty in the aquifer properties leads to uncertainty in the paths, such that contaminated water may have moved through a much larger part of the formations in the study area. The uncertainty in these paths could potentially be reduced by further field studies, such as tracer tests, that characterize flow paths directly.

Simulated contributing areas indicate the general configuration of groundwater flow towards production well MG-202 (L-22) in the study area, and as simulated, contributing areas likely do not include any identified contaminant source in North Penn Area 7. Recharge to wells generally comes from infiltration near the well and over an area that extends upgradient from the well. The contributing area is more complex at groundwater divides, can extend in more than one direction, and can capture recharge from thousands of feet away. Contributing areas to wells in areas with many wells are particularly complex and, in some cases, include areas that contribute flow to streams that subsequently recharge the aquifer through stream loss. In these cases, water-quality constituents in the surface water may be drawn into nearby pumped wells.

The groundwater-flow model was used to determine the contributing area for well MG-76 (L-17) when production well MG-202 was shutdown. Results of the simulated shutdown of well MG-202 (L-22) under steady-state 2005 conditions show that the area contributing recharge to well MG-76 (L-17) when MG-202 (L-22) is not pumping shifts downstream and is similar to the area contributing recharge to MG-202 (L-22) when both wells are pumped. This result is consistent with the anecdotal account that pumped well MG-202 (L-22) "protects" well MG-76 (L-17) from drawing in contaminated water if the contaminant source is in the overlapping area that contributes recharge to both wells. Simulation of the MG-202 (L-22) shutdown under transient conditions shows that the regionalscale groundwater-flow model is, in general, able to simulate observed aquifer response at the scale of the MG-202 (L-22) aquifer test, although the model does not include sufficient detail to accurately simulate all measured water-level changes.

Concentrations of constituents in groundwater samples collected by CDM in fall 2005 are compared with groundwater-flow simulations for the year 2005 to provide a qualitative assessment of model results, acknowledging that a snapshot of groundwater quality may not exactly match steady-state flow paths. The observed spatial distribution of selected constituents, including TCE, CFC-11, CFC-113 in groundwater in 2005 and the chloride/bromide mass ratios for 2006, generally were supportive of, or consistent with, the model results of the 2005 groundwater-flow simulation at North Penn Area 7.

\section{References Cited}

Argus Interware, Inc., 1997, User's Guide Argus ONETM, Argus Open Numerical Environments-A GIS Modeling System, Version 4.0: Jericho, N.Y., Argus Holdings, Limited, 506 p.

Barton, G.J., Risser, D.W., Galeone, D.G., and Goode, D.J., 2003, Case study for delineating a contributing area to a well in a fractured siliciclastic-bedrock aquifer near Lansdale, Pennsylvania: U.S. Geological Survey WaterResources Investigations Report 02-4271, 46 p.

Berg, T.M., Edmunds, W.E., Geyer, A.R., and others, comps., 1980, Geologic map of Pennsylvania: Pennsylvania Geological Survey, 4th Series, Map 1, 2nd edition, scale 1:250,000, 2 sheets.

Berg, T.M., Barnes, J.H., Sevon, W.D., Skema, V.W., Wilshusen, J.P., and Yannacucci, D.S., 1989, Physiographic Provinces of Pennsylvania: Pennsylvania Geological Survey, 4th ser., map 13, scale 1:2,000,000.

Biesecker, J.E., Lescinsky, J.B., and Wood, C.R., 1968, Water resources of the Schuylkill River Basin: Pennsylvania Department of Environmental Protection Water Resources Bulletin, no. 3, 198 p.

Black \& Veatch Waste Science, Inc., 1994, Remedial Investigation Feasibility Study Report North Penn Area 6 Site Source Control Operable Unit, Lansdale, Pennsylvania, Work assignment no. 91-19-3LW9, contract no. 68-W80091: Prepared for the U.S. Environmental Protection Agency, December 20, 1994. 
Black \& Veatch Waste Science, Inc., 1999, Remedial Investigation Feasibility Study Report North Penn Area 6 Site Groundwater Operable Unit (OU3), Lansdale, Pennsylvania.Work assignment no. 004-RICO03W9, contract no. 68-S8-3002. Prepared for the U.S. Environmental Protection Agency, August 1999

Burns, D.A., Plummer, L.N., McDonnell, J.J., Busenberg, Eurybiades, Casile, G.C., Kendall, Carol, Hooper, R.P., Freer, J.E., Peters, N.E., Beven, Keith, and Schlosser, Pete, 2003, The geochemical evolution of riparian ground water in a forested Piedmont catchment: Ground Water, v. 41, no. 7, p. 913-925.

Chapelle, F.H, and Bradley, P.M, 1998, Selecting remediation goals by assessing the natural attenuation capacity of groundwater systems: Bioremediation Journal, v. 2, no. 3-4, p. 227-238.

CDM Federal Programs Corporation, 2003, Revised final remedial investigation report for North Penn Operable Unit 2 Spra-Fin property, North Wales, volume 1: U.S. Environmental Protection Agency work assignment no. 015-RICO03X1 document no. 3232-015-RT-RIRT-01570, June 23, 2003, accessed December 3, 2010, at http://loggerhead.epa. gov/arweb/public/pdf/464104.pdf.

CDM Federal Programs Corporation, 2011, Final remedial investigation report for North Penn Area 7 Superfund Site, Operable Unit 3, Montgomery County, Pennsylvania: U.S. Environmental Protection Agency contract no. EP-S3-0706, work assignment no. 024-RICO-03X1 document control no. 3330-024-RT-RIRT-01543, April 28, 2011.

CH2M-Hill, Inc., 1992, North Penn Area 7 Phase II RI/FS Work Plan. Work assignment no. 05-3LX1.0, contract no. 68-W8-0090: Prepared for the U.S. Environmental Protection Agency, February 1992.

Conger, R.W., 1999, Evaluation of geophysical logs at North Penn Area 6 Superfund Site, Lansdale, Montgomery County, Pennsylvania: U.S. Geological Survey Open-File Report 99-271A, 149 p.

Converse Consultants East, 1994, Report: Task 2-Investigation of regional and site groundwater quality Ford Electronics and Refrigeration Corporation (FERCO) - Church Road facility, Lansdale, Pennsylvania, Project No. 91-37322-07: Parsippany, N.J., Sept. 20, 1994, 2 vols.

Davis, S.N, Whittemore, D.O., Fabryka-Martin, 1998, Uses of chloride/bromide ratios in studies of potable water: Ground Water, v. 36, no. 2, p. 338-350.

Davis, S.N., Fabryka-Martin, J.T., and Wolfsberg, L.E., 2004, Variations of bromide in potable ground water in the United States: Ground Water, v. 42, no. 6, p. 902-909.
Durlin, R.R., and Schaffstall, W.P., 2000, Ground water in the clastic bedrock within the Triassic lowlands section of the Piedmont Physiographic Province, in Water resources data for Pennsylvania, water year 1999, volume 1, Delaware River Basin: U.S. Geological Survey Water-Data Report PA-00-1, p. 1-24, accessed December 3, 2010, at http:// pa.water.usgs.gov/infodata/surfacewater/annual_rpt/wy00/ pdfs/nawqa-piedmont.pdf.

Edmunds, W.M., 1996, Bromine geochemistry of British groundwaters: Mineralogical Magazine, v. 60, p. 275-284.

ESRI, 2006, ArcGIS 9.2, Using ArcGIS Desktop: Redlands, Calif., ESRI Inc., 452 p.

Geraghty \& Miller, Inc., 1993, Evaluation of groundwater pumpage and containment at the Merck \& Co., Inc., West Point, Pennsylvania, plant: Reston, Virginia, Dec. 3, 1993.

Golder and Associates, Inc., 2003, RI sampling data review, 1190 Church Road, North Penn Area 7 Superfund site, letter dated October 28, 2003, to U.S. Environmental Protection Agency, accessed December 3, 2010, at http://loggerhead. epa.gov/arweb/public/pdf/2037767.pdf.

Goode, D.J., and Senior, L.A., 1998, Review of aquifer test results for the Lansdale area, Montgomery County, Pennsylvania, 1980-95: U.S. Geological Survey Open-File Report 98-294, $70 \mathrm{p}$.

Goode, D.J., and Senior, L.A., 2000, Simulation of aquifer tests and ground-water flow paths at the local scale in fractured shales and sandstones of the Brunswick Group and Lockatong Formation, Lansdale, Montgomery County, Pennsylvania: U.S. Geological Survey Open-File Report 00-97, 46 p.

Halford, K.J., 1999, Effects of steady-state assumption on hydraulic conductivity and recharge estimates in a surficial aquifer system: Ground Water, v. 37, no. 1, p. 70-79.

Harbaugh, A.W., Banta, E.R., Hill, M.C., and McDonald, M.G., 2000, MODFLOW-2000, The U.S. Geological Survey modular ground-water model-User's guide to modularization concepts and the ground-water flow process: U.S. Geological Survey Open-File Report 00-92, 191 p.

Heimann, A.C., Friis, A.K, and Jakobsen, Rasmus, 2005, Effects of sulfate on anaerobic chloroethene degradation by an enriched culture under transient and steady-state hydrogen supply: Water Research, v. 39, no. 15, September 2005, p. 3579-3586.

Hill, M.C., Banta, E.R., Harbaugh, A.W., and Anderman, E.R., 2000, MODFLOW-2000, The U.S. Geological Survey modular ground-water model-User's guide to the observation, sensitivity, and parameter-estimation processes and three post-processing programs: U.S. Geological Survey Open-File Report 00-184, 220 p. 
Hill, M.C., and Tiedeman, C.R, 2007, Effective groundwater model calibration: With analysis of data, sensitivities, predictions, and uncertainty: Hoboken, N.J., John Wiley \& Sons, $455 \mathrm{p}$.

Insightful Corporation, 2008, S-Plus 7 for Windows statistical software documentation, accessed June 2, 2008, at http:// www.insightful.com/support/doc_splus_win.asp.

Johnson, A.I., 1967, Specific yield-compilation of specific yields for various materials: U.S. Geological Survey Water Supply Paper 1662-D, 74 p.

Kennedy, L.G., Everett, J.W., Ware, K.J., Parsons, Robert, and Green, Valerie, 1998, Iron and sulfur mineral analysis methods for natural attenuation assessments: Bioremediation Journal, v. 2, no. 3, p. 259-276.

Lewis-Brown, J.D., and Rice, D.E., 2002, Simulated groundwater flow, Naval Air Warfare Center, West Trenton, New Jersey: U.S. Geological Survey Water-Resources Investigations Report 02-4019, 44 p.

Lindsey, B.D., 2005, Hydrogeology and simulation of source areas of water to production wells in a colluvium-mantled carbonate-bedrock aquifer near Shippensburg, Cumberland, and Franklin Counties, Pennsylvania: U.S. Geological Survey Scientific Investigations Report 2005-5195, 49 p.

Longwill, S.M., and Wood, C.R., 1965, Ground-water resources of the Brunswick Formation in Montgomery and Berks Counties, Pennsylvania: Pennsylvania Geological Survey, 4th ser., Water Resource Report W22, 59 p.

Lyttle, P.T., and Epstein, J.B., 1987, Geologic map of the Newark $1^{\circ}$ x $2^{\circ}$ Quadrangle, New Jersey, Pennsylvania and New York: U.S. Geological Survey Miscellaneous Investigations Map I-1715, scale 1:250,000.

Martin, L.M, 1981, Source identification of TCE and other chlorinated organic groundwater pollutants in the upper Wissahickon watershed-phase II: Report prepared for the Wissahickon Valley Watershed Association in cooperation with the North Penn Water Authority, November 1981, $141 \mathrm{p}$.

Neupauer, R.M., and J.L. Wilson, 2004, Numerical implementation of a backward probabilistic model of ground water contamination: Ground Water, v. 42, no. 2, p. 179-189.

Newport, T.G., 1971, Groundwater resources of Montgomery County, Pennsylvania: Pennsylvania Geological Survey, 4th ser., Water Resource Report W29, 83 p.
Pollock, D.W., 1994, User's Guide for MODPATH/MODPATH-PLOT, Version 3: A particle tracking post-processing package for MODFLOW, the U.S. Geological Survey finite-difference ground-water flow model: U.S. Geological Survey Open-File Report 94-464, 6 chap.

Prudic, D.E., 1989, Documentation of a computer program to simulate stream-aquifer relations using a modular, finite-difference, ground-water flow model: U.S. Geological Survey Open-File Report 88-729, 113 p.

Rima, D.R., 1955, Ground water resources of the Lansdale area, Pennsylvania: Pennsylvania Geological Survey, 4th ser., Prog. Report 146, 24 p.

Risser, D.W., and Bird, P.H., 2003, Aquifer tests and simulation of ground-water flow in Triassic sedimentary rocks near Colmar, Bucks and Montgomery Counties, Pennsylvania: U.S. Geological Survey Water-Resources Investigations Report 03-4159, 73 p.

Schlische, R.W., 1992, Structural and stratigraphic development of the Newark extensional basin, eastern North America-Evidence for growth of the basin and its bounding structures: Geological Society of America Bulletin, v. 104 , p. $1246-1263$.

Senior, L.A., Cinotto, P.J., Conger, R.W., Bird, P.H., and Pracht, K.A., 2005, Interpretation of geophysical logs, aquifer tests, and water levels in wells in and near the North Penn Area 7 Superfund Site, Upper Gwynedd Township, Montgomery County, Pennsylvania, 2000-02: U.S. Geological Survey Scientific Investigations Report 2005-5069, $129 \mathrm{p}$.

Senior, L.A., Conger, R.W., and Bird, P.H., 2008, Geophysical logs, aquifer tests, and water levels in wells in and near the North Penn Area 7 Superfund Site, Upper Gwynedd Township, Montgomery County, Pennsylvania, 2002-06: U.S. Geological Survey Scientific Investigations Report 2008-5154, 277 p.

Senior, L.A., and Goode, D.J., 1999, Ground-water system, estimation of aquifer hydraulic properties, and effects of pumping on ground-water flow in Triassic sedimentary rocks in and near Lansdale, Pennsylvania: U.S. Geological Survey Water-Resources Investigations Report 99-4228, 112 p.

Senior, L.A., Rowland, C.A., and Prieto, D.A., 1998, Altitude and configuration of the potentiometric surface in Lansdale and vicinity, Montgomery County, Pennsylvania, August 22-23, 1996: U.S. Geological Survey Open-File Report 98-253, 1 plate, scale 1:24,000. 
Senior, L.A., and Ruddy, A.J., 2004, Altitude and configuration of the water-level surface in Mesozoic sedimentary rocks at and near the North Penn Area 7 Superfund site, Upper Gwynedd Township, Montgomery County, Pennsylvania, December 4-6, 2000: U.S. Geological Survey OpenFile Report 2004-1006, 1 pl., scale 1:24,000.

Senior, L.A., Sloto, R.A., and Reif, A.G., 1997, Hydrogeology and water quality of the West Valley Creek Basin, Chester County, Pennsylvania: U.S. Geological Survey WaterResources Investigations Report 94-4137, 160 p.

Senior, L.A., and Sloto, R.A., 2006, Arsenic, boron, and fluoride concentrations in ground water in and near diabase intrusions, Newark Basin, Southeastern Pennsylvania: U.S. Geological Survey Scientific Investigations Report 20065261, $105 \mathrm{p}$.

Sevon, W.D., comp., 2000, Physiographic provinces of Pennsylvania: Pennsylvania Geological Survey, 4th ser., map 13, scale 1:2,000,000.

Sloto, R.A., and Schreffler, C.L., 1994, Hydrogeology and ground-water quality of northern Bucks County, Pennsylvania: U.S. Geological Survey Water-Resources Investigations Report 94-4109, 85 p.

Starn, J.J., Bagtzoglou, A.C., and Robbins, G.A., 2010, Using atmospheric tracers to reduce uncertainty in groundwater recharge areas: Ground Water, v. 48, no. 6, p. 858-868.

Theis, C.V., 1935, The relation between the lowering of the piezometric surface and the rate and duration of discharge of a well using groundwater storage: Transactions American Geophysical Union, v. 16, p. 519-524.

Tiedeman, C. R., Lacombe, P. J. and Goode, D. J., 2010, Multiple well-shutdown tests and site-scale flow simulation in fractured rocks: Ground Water, v. 48, no. 3, p. 401-415.

Turner, D.P., 2006, Draft soil sampling summary tables, figures and the soil data validation narratives for the North Penn Area 7 Superfund Site, 205 Church Rd property, memorandum dated June 26, 2006, to site file: U.S. Environmental Protection Agency, accessed December 3, 2010, at http://loggerhead.epa.gov/arweb/public/pdf/2062825.pdf.

U.S. Environmental Protection Agency, 2010, NPL Site Narrative for Salford Quarry, accessed October 1, 2010, at: http:// www.epa.gov/superfund/sites/npl/nar1490.htm

VanHouten, F.B., 1962, Cyclic sedimentation and the origin of analcime-rich Upper Triassic Lockatong Formation, westcentral New Jersey and adjacent Pennsylvania: American Journal of Science, v. 260 no. 8, p. 561-576.

Vengosh, Avner, and Pankratov, Irena, 1998, Chloride/bromide and chloride/fluoride ratios of domestic sewage effluents and associated contaminated ground water: Ground Water, v. 36 , no. 5 , p. $815-824$.
White, K.E., and Sloto, R.A., 1990, Base-flow frequency characteristics of selected Pennsylvania streams: U.S. Geological Survey Water-Resources Investigations Report 90-4169, $67 \mathrm{p}$.

Wiedemeier, T.H., Swanson, M.A., Moutoux, D.E., Gordon, E.K., Wilson, J.T., Wilson, B.H., Kampbell, D.H., Haas, P.E., Miller, R.N., Hansen, J.E., and Chapelle, F.H., 1998, Technical protocol for evaluating natural attenuation of chlorinated solvents in ground water: U.S. Environmental Protection Agency report EPA/600/R-98/128, accessed February 14, 2012, at http://www.epa.gov/superfund/health/ conmedia/gwdocs/protocol.htm.

Winston, R.B., 2000, Graphical user interface for MODFLOW, version 4: U.S. Geological Survey Open-File Report 00-315, $27 \mathrm{p}$. 
Table 6. Water levels in wells used for calibration of the groundwater-flow model for North Penn Area 7 Superfund site, Upper Gwynedd Township and vicinity, Montgomery County, Pennsylvania.

[USGS, U.S. Geological Survey; UTM-18, Universal Transverse Mercator, zone 18; NAD 27, North American Datum of 1927; --. no data; altitude in meters above North American Vertical Datum of 1929; GPS, Global Positioning System]

\begin{tabular}{|c|c|c|c|c|c|c|c|c|c|c|c|}
\hline \multirow{2}{*}{$\begin{array}{c}\text { USGS } \\
\text { well } \\
\text { identifier }^{1}\end{array}$} & \multirow{2}{*}{$\begin{array}{c}\text { Owner's } \\
\text { well } \\
\text { name or } \\
\text { number }\end{array}$} & \multicolumn{2}{|c|}{$\begin{array}{l}\text { UTM-18/NAD } 27 \\
\text { coordinates } \\
\text { (meters) }\end{array}$} & \multicolumn{2}{|c|}{$\begin{array}{c}\text { Altitude of open } \\
\text { interval } \\
\text { (meters) }\end{array}$} & \multicolumn{3}{|c|}{$\begin{array}{l}\text { Altitude of measured water levels } \\
\text { (meters) }\end{array}$} & \multirow{2}{*}{$\begin{array}{c}\text { Data } \\
\text { source }^{2}\end{array}$} & \multirow{2}{*}{$\begin{array}{l}\text { Location } \\
\text { method }\end{array}$} & \multirow{2}{*}{$\begin{array}{l}\text { USGS site } \\
\text { identifier }\end{array}$} \\
\hline & & Easting & Northing & $\begin{array}{l}\text { Top of } \\
\text { interval }\end{array}$ & $\begin{array}{l}\text { Bottom of } \\
\text { interval }\end{array}$ & $\begin{array}{c}1996 \\
\text { calibration } \\
\text { head }\end{array}$ & $\begin{array}{c}2000 \\
\text { calibration } \\
\text { head }\end{array}$ & $\begin{array}{c}2005 \\
\text { calibration } \\
\text { head }\end{array}$ & & & \\
\hline 62 & L-3 & 476031.6 & 4454323.5 & 102.14 & -6.07 & -- & 98.94 & -- & $\mathrm{c}$ & Surveyed & 401428075165501 \\
\hline 69 & L-10 & 474614.6 & 4454327.8 & 88.33 & 19.75 & 87.31 & -- & -- & a & Surveyed & 401427075175401 \\
\hline 72 & L-13 & 476650.6 & 4452806.2 & 94.82 & 14.97 & 97.71 & 94.19 & 102.78 & $\mathrm{c}$ & Surveyed & 401338075162801 \\
\hline 80 & & 475084.2 & 4455217.8 & 57.30 & 1.83 & 95.63 & -- & -- & $\mathrm{a}$ & Surveyed & 401454075173401 \\
\hline 81 & LB6 & 475550.4 & 4454741.5 & 94.49 & -2.13 & 92.90 & -- & -- & $\mathrm{a}$ & Surveyed & 401442075171501 \\
\hline 82 & LB5 & 475426.0 & 4456017.1 & 89.12 & -19.69 & 91.14 & -- & -- & $\mathrm{a}$ & Surveyed & 401523075171801 \\
\hline 147 & Ford 4 & 476035.8 & 4452743.4 & 92.35 & -5.18 & -- & 95.52 & -- & $\mathrm{c}$ & Map & 401336075165401 \\
\hline 152 & $\mathrm{AO} 1$ & 476207.0 & 4455360.7 & 101.22 & 46.06 & 93.38 & -- & -- & $\mathrm{a}$ & Surveyed & 401503075164301 \\
\hline 154 & & 475829.7 & 4454932.1 & 99.21 & 49.53 & 93.39 & -- & -- & a & Surveyed & 401447075170301 \\
\hline 157 & & 475245.5 & 4455567.4 & 82.88 & 10.33 & 95.43 & -- & -- & $\mathrm{a}$ & Surveyed & 401507075173001 \\
\hline 163 & & 474854.8 & 4455113.3 & 94.24 & 11.64 & 95.79 & -- & -- & $\mathrm{b}$ & Surveyed & 401453075174401 \\
\hline 164 & & 474925.4 & 4454959.8 & 94.52 & -19.78 & 95.10 & -- & -- & $\mathrm{a}$ & Surveyed & 401448075174101 \\
\hline 174 & CL-2 & 476163.2 & 4452060.5 & 95.59 & 62.07 & -- & 95.92 & -- & $\mathrm{c}$ & Map & 401315075164901 \\
\hline 175 & $\mathrm{RI}-7 \mathrm{I}^{3}$ & 476252.0 & 4451808.6 & 104.32 & 61.65 & -- & 98.54 & -- & $\mathrm{c}$ & Map & 401306075164401 \\
\hline 498 & L-23 & 474203.9 & 4455370.7 & 76.99 & -66.26 & 97.94 & -- & -- & a & Surveyed & 401501075181201 \\
\hline 618 & & 476496.1 & 4455538.2 & 96.86 & 6.79 & 93.14 & -- & -- & a & Surveyed & 401506075163501 \\
\hline 1124 & & 476838.8 & 4455203.7 & 95.75 & -13.98 & 97.40 & 98.9 & -- & $\mathrm{a}$ & Surveyed & 401504075161501 \\
\hline 1126 & & 477147.5 & 4455626.7 & 93.99 & 5.30 & 96.00 & -- & -- & d & GPS & 401516075155901 \\
\hline 1128 & & 473375.2 & 4455579.7 & 83.00 & -65.75 & 80.95 & -- & -- & a & Surveyed & 401508075184801 \\
\hline 1144 & & 475513.6 & 4452035.9 & 96.41 & 76.60 & -- & 93.56 & -- & $\mathrm{c}$ & Map & 401314075171801 \\
\hline 1145 & $\mathrm{~T}-14$ & 475608.0 & 4452004.5 & 94.96 & 75.15 & -- & 93.69 & 97.64 & $\mathrm{c}$ & Map & 401314075171401 \\
\hline 1146 & $\mathrm{~T}-4$ & 475632.5 & 4452219.7 & 98.97 & 79.16 & -- & 94.62 & 98.30 & $\mathrm{c}$ & Map & 401318075171101 \\
\hline 1147 & $\mathrm{~T}-11$ & 475611.8 & 4452323.5 & 100.25 & 80.44 & -- & 94.67 & 98.86 & $\mathrm{c}$ & Map & 401322075171201 \\
\hline 1148 & $\mathrm{~T}-12$ & 475538.6 & 4452374.3 & 104.12 & 84.31 & -- & 94.61 & 98.78 & $\mathrm{c}$ & Map & 401324075171601 \\
\hline 1149 & $\mathrm{~T}-10$ & 475490.6 & 4452282.3 & 103.30 & 83.48 & -- & 94.30 & 98.43 & $\mathrm{c}$ & Map & 401321075171701 \\
\hline 1169 & & 475871.5 & 4453021.1 & 106.68 & 91.74 & 101.42 & -- & -- & $\mathrm{a}$ & Map & 401345075170101 \\
\hline 1179 & & 473808.4 & 4457899.9 & 97.84 & -62.48 & 76.22 & -- & -- & $\mathrm{b}$ & Map & 401623075182901 \\
\hline 1270 & & 477157.9 & 4455334.6 & 97.99 & 6.25 & 98.15 & 99.58 & -- & a & Surveyed & 401506075160001 \\
\hline 1284 & & 476764.6 & 4459000.1 & 68.58 & -42.98 & 90.73 & -- & -- & $\mathrm{b}$ & Map & 401659075162401 \\
\hline 1440 & & 475649.9 & 4455672.1 & 100.68 & 38.65 & 95.25 & -- & -- & $\mathrm{a}$ & Surveyed & 401511075171101 \\
\hline 1441 & & 474508.8 & 4453321.5 & 89.37 & 40.87 & 80.46 & -- & -- & $\mathrm{a}$ & Surveyed & 401354075175901 \\
\hline 1442 & & 475621.7 & 4454801.2 & 100.28 & 79.86 & 93.26 & -- & -- & a & Surveyed & 401443075171201 \\
\hline
\end{tabular}


Table 6. Water levels in wells used for calibration of the groundwater-flow model for North Penn Area 7 Superfund site, Upper Gwynedd Township and vicinity, Montgomery County, Pennsylvania.-Continued

[USGS, U.S. Geological Survey; UTM-18, Universal Transverse Mercator, zone 18; NAD 27, North American Datum of 1927; --. no data; altitude in meters above North American Vertical Datum of 1929; GPS, Global Positioning System]

\begin{tabular}{|c|c|c|c|c|c|c|c|c|c|c|c|}
\hline \multirow{2}{*}{$\begin{array}{c}\text { USGS } \\
\text { well } \\
\text { identifier }^{1}\end{array}$} & \multirow{2}{*}{$\begin{array}{c}\text { Owner's } \\
\text { well } \\
\text { name or } \\
\text { number }\end{array}$} & \multicolumn{2}{|c|}{$\begin{array}{l}\text { UTM-18/NAD } 27 \\
\text { coordinates } \\
\text { (meters) }\end{array}$} & \multicolumn{2}{|c|}{$\begin{array}{c}\text { Altitude of open } \\
\text { interval } \\
\text { (meters) }\end{array}$} & \multicolumn{3}{|c|}{$\begin{array}{l}\text { Altitude of measured water levels } \\
\text { (meters) }\end{array}$} & \multirow{2}{*}{$\begin{array}{c}\text { Data } \\
\text { source }^{2}\end{array}$} & \multirow{2}{*}{$\begin{array}{l}\text { Location } \\
\text { method }\end{array}$} & \multirow{2}{*}{$\begin{array}{l}\text { USGS site } \\
\text { identifier }\end{array}$} \\
\hline & & Easting & Northing & $\begin{array}{c}\text { Top of } \\
\text { interval }\end{array}$ & $\begin{array}{l}\text { Bottom of } \\
\text { interval }\end{array}$ & $\begin{array}{c}1996 \\
\text { calibration } \\
\text { head }\end{array}$ & $\begin{array}{c}2000 \\
\text { calibration } \\
\text { head }\end{array}$ & $\begin{array}{c}2005 \\
\text { calibration } \\
\text { head }\end{array}$ & & & \\
\hline 1443 & & 476118.5 & 4455278.1 & 103.97 & 34.17 & 94.17 & -- & -- & $\mathrm{a}$ & Surveyed & 401457075165301 \\
\hline 1446 & & 476361.7 & 4455514.7 & 103.30 & 65.20 & 93.18 & -- & -- & a & Surveyed & 401504075164101 \\
\hline 1447 & & 476305.4 & 4455674.1 & 100.77 & 62.36 & 93.29 & -- & -- & $\mathrm{a}$ & Surveyed & 401508075164401 \\
\hline 1448 & & 474190.7 & 4452163.3 & 95.40 & 79.55 & 90.50 & -- & -- & $\mathrm{a}$ & Map & 401317075181201 \\
\hline 1449 & & 472202.6 & 4454955.4 & 71.63 & 45.87 & 77.46 & -- & 77.35 & $\mathrm{~d}$ & GPS & 401446075193701 \\
\hline 1450 & & 474644.7 & 4453641.7 & 96.93 & 72.54 & 86.90 & -- & -- & $\mathrm{a}$ & Map & 401406075175501 \\
\hline 1455 & & 474428.7 & 4452778.7 & 93.27 & 34.44 & 91.70 & 92.14 & -- & $\mathrm{a}$ & Map & 401337075180201 \\
\hline 1456 & & 471577.4 & 4454885.9 & 73.15 & 1.83 & 89.24 & -- & -- & $\mathrm{b}$ & Map & 401445075200301 \\
\hline 1457 & & 471973.7 & 4453435.4 & 79.55 & 55.17 & 73.08 & -- & -- & $\mathrm{b}$ & Map & 401358075194601 \\
\hline 1458 & & 471617.8 & 4453066.7 & 75.90 & 55.29 & 66.47 & -- & -- & $\mathrm{b}$ & Map & 401346075200101 \\
\hline 1459 & & 471976.0 & 4454052.0 & 77.72 & 53.34 & 68.90 & -- & -- & $\mathrm{a}$ & Map & 401418075194601 \\
\hline 1460 & & 476819.6 & 4456115.2 & 92.26 & 30.39 & 92.54 & -- & -- & a & Surveyed & 401527075162301 \\
\hline 1461 & & 477585.1 & 4457085.6 & 81.69 & 14.94 & 88.10 & -- & -- & $\mathrm{a}$ & Map & 401557075154901 \\
\hline 1462 & & 478097.9 & 4454709.5 & 126.19 & 101.80 & 122.80 & 121.09 & -- & $\mathrm{a}$ & Map & 401440075152701 \\
\hline 1463 & & 476076.1 & 4457294.7 & 75.04 & 29.02 & 87.17 & -- & -- & $\mathrm{a}$ & Surveyed & 401604075165001 \\
\hline 1464 & & 473382.5 & 4457561.7 & 87.63 & 16.46 & 65.55 & -- & -- & $\mathrm{b}$ & Map & 401612075184701 \\
\hline 1472 & & 471947.6 & 4452788.0 & 75.59 & 51.21 & 71.74 & -- & -- & $\mathrm{b}$ & Map & 401337075194701 \\
\hline 1473 & & 471894.5 & 4451247.1 & 91.44 & 67.06 & 93.92 & 93.23 & -- & $\mathrm{c}$ & Map & 401247075194901 \\
\hline 1474 & & 472739.3 & 4456053.3 & 87.78 & 55.47 & 87.63 & -- & -- & $\mathrm{b}$ & Map & 401523075191401 \\
\hline 1475 & & 473316.2 & 4452135.4 & 84.73 & 60.35 & 86.75 & 85.83 & -- & $\mathrm{c}$ & Map & 401316075184901 \\
\hline 1476 & & 472655.2 & 4452415.3 & 67.97 & 54.25 & 74.28 & 74.59 & -- & $\mathrm{c}$ & Map & 401325075191701 \\
\hline 1477 & & 474619.0 & 4452932.3 & 92.96 & 50.29 & 92.45 & 90.06 & -- & $\mathrm{a}$ & Map & 401342075175401 \\
\hline 1478 & & 474291.6 & 4454043.7 & 90.83 & 29.87 & 86.71 & -- & -- & $\mathrm{a}$ & Map & 401418075180801 \\
\hline 1479 & & 472397.5 & 4453002.1 & 80.16 & 55.78 & 75.34 & -- & -- & $\mathrm{b}$ & Map & 401344075192801 \\
\hline 1480 & & 478028.5 & 4455234.4 & 116.43 & 92.05 & 115.95 & -- & -- & $\mathrm{a}$ & Map & 401457075153001 \\
\hline 1481 & & 473391.1 & 4453306.9 & 84.43 & -0.91 & 82.46 & -- & -- & $\mathrm{a}$ & Map & 401354075184601 \\
\hline 1482 & & 472819.4 & 4451951.8 & 91.74 & 63.09 & 82.87 & 81.87 & -- & $\mathrm{c}$ & Map & 401309075190901 \\
\hline 1483 & & 474476.3 & 4456106.4 & 100.00 & 75.62 & 94.19 & -- & -- & $\mathrm{a}$ & Surveyed & 401526075180101 \\
\hline 1484 & & 475245.4 & 4456461.0 & 72.51 & -34.17 & 83.88 & -- & -- & $\mathrm{b}$ & Surveyed & 401537075172701 \\
\hline 1485 & & 473161.5 & 4455188.4 & 81.38 & 57.00 & 78.30 & -- & -- & $\mathrm{a}$ & Map & 401455075185601 \\
\hline 1487 & & 474273.1 & 4455554.6 & 97.54 & 73.15 & 92.00 & -- & -- & $\mathrm{a}$ & Map & 401507075180901 \\
\hline 1488 & & 470326.7 & 4455260.7 & 66.45 & -14.02 & 61.55 & -- & -- & $\mathrm{b}$ & Map & 401457075205601 \\
\hline
\end{tabular}


Table 6. Water levels in wells used for calibration of the groundwater-flow model for North Penn Area 7 Superfund site, Upper Gwynedd Township and vicinity, Montgomery County, Pennsylvania.-Continued

[USGS, U.S. Geological Survey; UTM-18, Universal Transverse Mercator, zone 18; NAD 27, North American Datum of 1927; --. no data; altitude in meters above North American Vertical Datum of 1929; GPS, Global Positioning System]

\begin{tabular}{|c|c|c|c|c|c|c|c|c|c|c|c|}
\hline \multirow{2}{*}{$\begin{array}{c}\text { USGS } \\
\text { well } \\
\text { identifier }^{1}\end{array}$} & \multirow{2}{*}{$\begin{array}{c}\text { Owner's } \\
\text { well } \\
\text { name or } \\
\text { number }\end{array}$} & \multicolumn{2}{|c|}{$\begin{array}{l}\text { UTM-18/NAD } 27 \\
\text { coordinates } \\
\text { (meters) }\end{array}$} & \multicolumn{2}{|c|}{$\begin{array}{c}\text { Altitude of open } \\
\text { interval } \\
\text { (meters) }\end{array}$} & \multicolumn{3}{|c|}{$\begin{array}{l}\text { Altitude of measured water levels } \\
\text { (meters) }\end{array}$} & \multirow{2}{*}{$\begin{array}{c}\text { Data } \\
\text { source }^{2}\end{array}$} & \multirow{2}{*}{$\begin{array}{c}\text { Location } \\
\text { method }\end{array}$} & \multirow{2}{*}{$\begin{array}{l}\text { USGS site } \\
\text { identifier }\end{array}$} \\
\hline & & Easting & Northing & $\begin{array}{l}\text { Top of } \\
\text { interval }\end{array}$ & $\begin{array}{l}\text { Bottom of } \\
\text { interval }\end{array}$ & $\begin{array}{c}1996 \\
\text { calibration } \\
\text { head }\end{array}$ & $\begin{array}{c}2000 \\
\text { calibration } \\
\text { head }\end{array}$ & $\begin{array}{c}2005 \\
\text { calibration } \\
\text { head }\end{array}$ & & & \\
\hline 1489 & & 472332.6 & 4454636.5 & 72.73 & 42.67 & 67.70 & -- & -- & $\mathrm{a}$ & Map & 401437075193101 \\
\hline 1492 & & 471317.9 & 4454979.4 & 88.70 & 64.31 & 85.67 & -- & -- & $\mathrm{b}$ & Map & 401448075201401 \\
\hline 1493 & & 471269.0 & 4454548.0 & 79.25 & 54.86 & 82.70 & -- & -- & $\mathrm{b}$ & Map & 401434075201601 \\
\hline 1494 & & 474085.2 & 4455863.5 & 93.88 & 69.49 & 91.54 & -- & -- & $\mathrm{a}$ & Map & 401517075181701 \\
\hline 1495 & & 474182.3 & 4449727.7 & 101.50 & 63.40 & 95.57 & -- & -- & $\mathrm{b}$ & Map & 401158075181201 \\
\hline 1496 & & 473426.6 & 4449915.2 & 85.95 & 55.47 & 89.83 & 89.34 & -- & $\mathrm{c}$ & Map & 401204075184401 \\
\hline 1501 & & 478074.9 & 4455018.2 & 124.97 & 100.58 & 125.01 & 123.88 & -- & $\mathrm{a}$ & Map & 401450075152801 \\
\hline 1502 & & 477114.4 & 4457642.0 & 82.91 & 67.06 & 84.21 & -- & -- & $\mathrm{b}$ & Map & 401615075160901 \\
\hline 1503 & & 476899.3 & 4456810.2 & 90.83 & 86.26 & 95.40 & -- & -- & a & Map & 401548075161801 \\
\hline 1504 & & 473358.8 & 4450964.3 & 98.15 & 99.36 & 103.78 & 103.58 & -- & $\mathrm{c}$ & Map & 401238075184701 \\
\hline 1505 & & 476033.1 & 4451911.0 & 100.04 & 79.56 & 98.13 & 97.77 & -- & $\mathrm{c}$ & Map & 401309075165401 \\
\hline 1506 & & 477574.3 & 4455348.0 & 107.96 & 83.58 & 111.45 & -- & -- & $\mathrm{a}$ & Surveyed & 401502075155201 \\
\hline 1507 & & 472697.1 & 4450812.4 & 95.40 & 58.83 & 91.96 & 92.55 & -- & $\mathrm{c}$ & Map & 401233075191501 \\
\hline 1508 & & 476809.8 & 4458413.7 & 91.44 & 67.06 & 88.88 & -- & -- & $\mathrm{b}$ & Map & 401640075162201 \\
\hline 1509 & & 477280.0 & 4457734.0 & 85.95 & 64.62 & 87.78 & -- & -- & $\mathrm{b}$ & Map & 401618075160201 \\
\hline 1510 & & 476005.0 & 4457830.4 & 87.48 & 63.09 & 85.70 & -- & -- & $\mathrm{b}$ & Map & 401621075165601 \\
\hline 1542 & N6 & 474800.9 & 4450835.0 & 72.85 & 69.80 & 91.45 & -- & -- & $\mathrm{a}$ & Map & 401234075174601 \\
\hline 1543 & N7 & 474967.2 & 4451205.2 & 63.11 & 60.07 & 81.46 & 71.34 & 70.71 & $\mathrm{a}$ & Map & 401246075173901 \\
\hline 1544 & N8 & 474493.2 & 4450712.9 & 73.24 & 70.20 & 92.33 & 90.74 & 92.01 & $\mathrm{c}$ & Map & 401230075175901 \\
\hline 1545 & N9 & 473900.8 & 4450437.4 & 78.03 & 71.94 & 88.35 & 87.58 & 88.81 & $\mathrm{c}$ & Map & 401221075182401 \\
\hline 1546 & N10 & 474232.5 & 4450621.6 & 72.54 & 69.49 & 86.87 & 85.61 & 88.93 & $\mathrm{c}$ & Map & 401227075181001 \\
\hline 1547 & N11 & 474304.9 & 4450898.9 & 77.93 & 74.89 & 85.65 & 81.92 & 88.06 & $\mathrm{c}$ & Map & 401236075180701 \\
\hline 1548 & N12 & 473217.2 & 4450871.6 & 75.81 & 72.76 & 84.19 & 78.45 & 78.45 & $\mathrm{c}$ & Map & 401235075185301 \\
\hline 1549 & $\mathrm{~N} 12 \mathrm{D}$ & 473217.2 & 4450871.6 & 8.42 & -0.73 & 81.60 & 78.64 & 78.72 & $\mathrm{c}$ & Map & 401235075185302 \\
\hline 1550 & N13 & 473406.9 & 4451087.3 & 77.85 & 74.80 & 83.10 & 77.83 & -- & $\mathrm{c}$ & Map & 401242075184501 \\
\hline 1551 & N16 & 473810.6 & 4451670.9 & 72.25 & 69.20 & 87.54 & 84.46 & 85.49 & $\mathrm{a}$ & Map & 401301075182801 \\
\hline 1552 & N17 & 474000.3 & 4451886.6 & 83.84 & 80.79 & 90.57 & 86.92 & 88.00 & $\mathrm{a}$ & Map & 401308075182001 \\
\hline 1553 & N19 & 474569.4 & 4452347.5 & 77.23 & 74.18 & 92.52 & 88.57 & 89.69 & $\mathrm{a}$ & Map & 401323075175601 \\
\hline 1554 & $\mathrm{~N} 20$ & 474190.6 & 4452071.3 & 85.80 & 79.71 & 91.49 & 87.38 & 89.04 & $\mathrm{a}$ & Map & 401314075181201 \\
\hline 1555 & N20D & 474213.6 & 4452071.3 & 23.56 & 17.47 & 90.13 & 75.58 & -- & $\mathrm{c}$ & Map & 401314075181101 \\
\hline 1556 & N21 & 474567.8 & 4451884.7 & 78.46 & 75.42 & 91.29 & 91.14 & 95.70 & $\mathrm{a}$ & Map & 401308075175601 \\
\hline 1557 & N22 & 474804.0 & 4451760.7 & 81.08 & 78.03 & 92.93 & 91.29 & 95.41 & a & Map & 401304075174601 \\
\hline
\end{tabular}


Table 6. Water levels in wells used for calibration of the groundwater-flow model for North Penn Area 7 Superfund site, Upper Gwynedd Township and vicinity, Montgomery County, Pennsylvania.-Continued

[USGS, U.S. Geological Survey; UTM-18, Universal Transverse Mercator, zone 18; NAD 27, North American Datum of 1927; --. no data; altitude in meters above North American Vertical Datum of 1929; GPS, Global Positioning System]

\begin{tabular}{|c|c|c|c|c|c|c|c|c|c|c|c|}
\hline \multirow{2}{*}{$\begin{array}{c}\text { USGS } \\
\text { well } \\
\text { identifier }^{1}\end{array}$} & \multirow{2}{*}{$\begin{array}{c}\text { Owner's } \\
\text { well } \\
\text { name or } \\
\text { number }\end{array}$} & \multicolumn{2}{|c|}{$\begin{array}{l}\text { UTM-18/NAD } 27 \\
\text { coordinates } \\
\text { (meters) }\end{array}$} & \multicolumn{2}{|c|}{$\begin{array}{c}\text { Altitude of open } \\
\text { interval } \\
\text { (meters) }\end{array}$} & \multicolumn{3}{|c|}{$\begin{array}{l}\text { Altitude of measured water levels } \\
\text { (meters) }\end{array}$} & \multirow{2}{*}{$\begin{array}{c}\text { Data } \\
\text { source }^{2}\end{array}$} & \multirow{2}{*}{$\begin{array}{l}\text { Location } \\
\text { method }\end{array}$} & \multirow{2}{*}{$\begin{array}{l}\text { USGS site } \\
\text { identifier }\end{array}$} \\
\hline & & Easting & Northing & $\begin{array}{c}\text { Top of } \\
\text { interval }\end{array}$ & $\begin{array}{l}\text { Bottom of } \\
\text { interval }\end{array}$ & $\begin{array}{c}1996 \\
\text { calibration } \\
\text { head }\end{array}$ & $\begin{array}{c}2000 \\
\text { calibration } \\
\text { head }\end{array}$ & $\begin{array}{c}2005 \\
\text { calibration } \\
\text { head }\end{array}$ & & & \\
\hline 1558 & $\mathrm{~N} 22 \mathrm{D}$ & 474803.9 & 4451760.7 & 9.70 & -2.49 & 89.36 & 85.81 & 90.30 & $\mathrm{c}$ & Map & 401304075174602 \\
\hline 1561 & $\mathrm{~N} 25$ & 474589.1 & 4451144.3 & 70.43 & 67.39 & 87.57 & 84.85 & 87.80 & $\mathrm{a}$ & Map & 401244075175501 \\
\hline 1562 & N26 & 473644.5 & 4451364.0 & 80.22 & 77.18 & 84.03 & 74.92 & 75.11 & $\mathrm{c}$ & Map & 401251075183501 \\
\hline 1563 & N28 & 473739.6 & 4451547.9 & 73.00 & 69.95 & 85.22 & 80.40 & 80.66 & a & Map & 401257075183101 \\
\hline 1564 & N29 & 473999.7 & 4451732.4 & 80.64 & 77.59 & 89.56 & 85.63 & 86.49 & a & Map & 401303075182001 \\
\hline 1565 & N30 & 473905.0 & 4451640.6 & 69.74 & 66.69 & 88.24 & 69.21 & 84.72 & $\mathrm{a}$ & Map & 401300075182401 \\
\hline 1570 & $9-85$ & 473975.9 & 4451486.0 & 75.90 & 72.85 & 78.30 & -- & 75.66 & $\mathrm{a}$ & Map & 401255075182101 \\
\hline 1571 & $10-85$ & 474756.4 & 4451791.9 & 88.24 & 85.19 & 91.64 & 89.39 & 93.86 & $\mathrm{a}$ & Map & 401305075174801 \\
\hline 1572 & $11-85$ & 474139.4 & 4451022.6 & 76.57 & 73.52 & 83.60 & 80.67 & 87.26 & $\mathrm{c}$ & Map & 401240075181401 \\
\hline 1600 & Rog 3I & 475689.6 & 4453755.5 & 71.52 & 65.42 & -- & 96.37 & 98.98 & $\mathrm{c}$ & Surveyed & 401409075170701 \\
\hline 1601 & $\operatorname{Rog} 3 \mathrm{~S}$ & 475692.2 & 4453758.1 & 106.20 & 80.81 & -- & 91.87 & 94.41 & $\mathrm{c}$ & Surveyed & 401409075170702 \\
\hline 1602 & $\operatorname{Rog} 2 \mathrm{I}$ & 475720.0 & 4453665.0 & 81.67 & 75.57 & -- & 95.91 & 98.45 & $\mathrm{c}$ & Surveyed & 401406075170601 \\
\hline 1603 & $\operatorname{Rog} 2 \mathrm{~S}$ & 475721.9 & 4453667.5 & 110.32 & 85.02 & -- & -- & 94.14 & & Surveyed & \\
\hline 1822 & & 477919.2 & 4451619.7 & 133.50 & 35.05 & -- & 129.74 & -- & $\mathrm{d}$ & GPS & 401300075153301 \\
\hline 1823 & & 475772.5 & 4449852.2 & 86.87 & 64.01 & -- & 91.54 & -- & $\mathrm{d}$ & GPS & 401203075170301 \\
\hline 1824 & & 474833.5 & 4450306.3 & 88.39 & 88.39 & -- & 89.41 & -- & $\mathrm{d}$ & GPS & 401217075174301 \\
\hline 1833 & & 474724.7 & 4449294.2 & 111.25 & 77.72 & -- & 99.70 & -- & $\mathrm{c}$ & Map & 401144075174901 \\
\hline 1834 & & 475787.6 & 4450132.1 & 103.02 & 78.64 & -- & 97.69 & -- & $\mathrm{d}$ & GPS & 401212075170301 \\
\hline 1835 & & 475453.1 & 4449624.8 & 90.83 & 28.35 & -- & 87.54 & -- & $\mathrm{d}$ & GPS & 401155075171701 \\
\hline 1836 & & 475948.6 & 4451109.9 & 99.06 & 63.09 & -- & 97.53 & -- & $\mathrm{d}$ & GPS & 401243075165601 \\
\hline 1837 & & 474867.7 & 4449153.1 & 111.25 & 62.48 & -- & 105.62 & -- & d & GPS & 401140075174201 \\
\hline 1838 & & 474789.2 & 4452531.0 & 102.11 & 78.33 & -- & 90.08 & -- & $\mathrm{d}$ & GPS & 401329075174501 \\
\hline 1839 & & 472972.6 & 4451389.7 & 94.49 & 70.10 & -- & 91.00 & -- & d & GPS & 401252075190201 \\
\hline 1840 & & 476867.2 & 4452712.4 & 106.68 & 42.98 & -- & 99.79 & -- & $\mathrm{d}$ & GPS & 401335075161701 \\
\hline 1841 & SF-2 & 476256.6 & 4451862.7 & 110.21 & 79.73 & -- & 98.53 & 102.11 & $\mathrm{~d}$ & GPS & 401308075165401 \\
\hline 1842 & $\mathrm{~T}-15$ & 475647.0 & 4452280.3 & 100.87 & 80.45 & -- & 94.38 & 98.46 & $\mathrm{c}$ & Surveyed & 401323075171201 \\
\hline 1843 & & 475688.4 & 4452231.1 & 98.09 & 92.30 & -- & 95.27 & -- & $\mathrm{d}$ & GPS & 401320075171101 \\
\hline 1844 & & 476519.4 & 4451658.7 & 108.87 & 97.74 & -- & 100.21 & 103.53 & $\mathrm{c}$ & Surveyed & 401302075163301 \\
\hline 1845 & & 476520.2 & 4451640.3 & 107.94 & 97.27 & -- & 99.77 & 103.53 & $\mathrm{c}$ & Surveyed & 401300075163401 \\
\hline 1846 & & 476465.7 & 4451764.3 & 107.04 & 96.37 & -- & 99.29 & 103.26 & $\mathrm{~d}$ & Surveyed & 401305075163601 \\
\hline 1847 & & 475973.3 & 4452512.8 & 98.17 & 90.55 & -- & 95.46 & 99.76 & $\mathrm{~d}$ & Surveyed & 401329075165701 \\
\hline 1848 & & 475998.9 & 4452322.1 & 94.57 & 90.00 & -- & 95.51 & 99.75 & $\mathrm{~d}$ & Surveyed & 401323075165601 \\
\hline
\end{tabular}


Table 6. Water levels in wells used for calibration of the groundwater-flow model for North Penn Area 7 Superfund site, Upper Gwynedd Township and vicinity, Montgomery County, Pennsylvania.-Continued

[USGS, U.S. Geological Survey; UTM-18, Universal Transverse Mercator, zone 18; NAD 27, North American Datum of 1927; --. no data; altitude in meters above North American Vertical Datum of 1929; GPS, Global Positioning System]

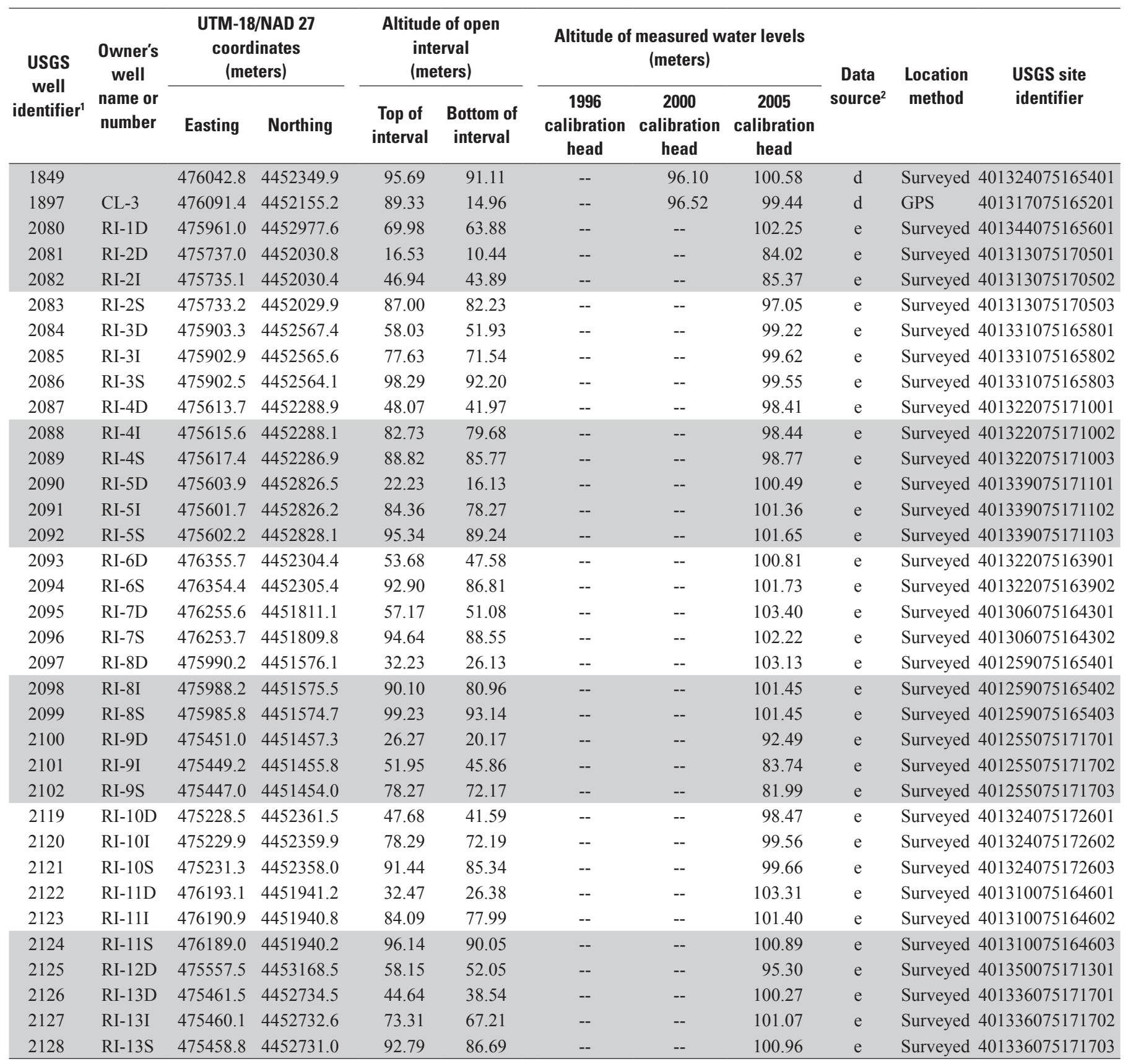

${ }^{1}$ MG- prefix omitted.

${ }^{2}$ Data sources:

a, 1996 data used in 1999 North Penn Area 6 model (except at wells 498, 618, and 624, which were probably in error)

b, 1996 data not used in 1999 North Penn Area 6 model

c, 2000 data

d, 2000 data for wells first measured for 2000 water-level map

e, 2005 data from new monitor wells at North Penn Area 7

${ }^{3}$ Well MG-175 orginally drilled as production well for Spra-Fin and later converted to screened monittor well RI-7I in 2004. 

For additional information:

Director

U.S. Geological Survey

215 Limekiln Road

New Cumberland, PA 17070

http://pa.water.usgs.gov/ 


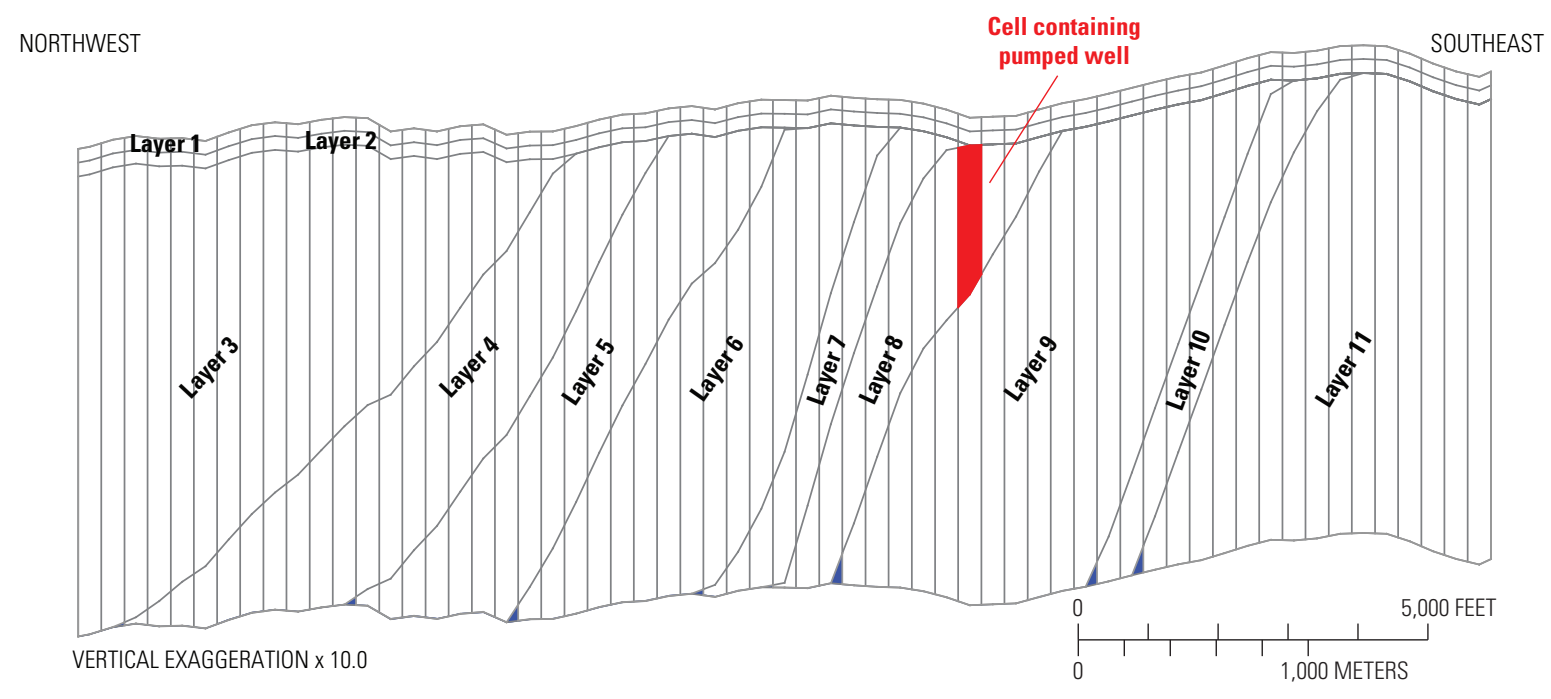

